\title{
Molecular signatures and prognosis of HPV-positive head and neck lesions
}

Citation for published version (APA):

Mooren, J. J. (2014). Molecular signatures and prognosis of HPV-positive head and neck lesions.

[Doctoral Thesis, Maastricht University]. Maastricht University. https://doi.org/10.26481/dis.20141116jm

Document status and date:

Published: 01/01/2014

DOI:

10.26481/dis.20141116jm

Document Version:

Publisher's PDF, also known as Version of record

\section{Please check the document version of this publication:}

- A submitted manuscript is the version of the article upon submission and before peer-review. There can be important differences between the submitted version and the official published version of record.

People interested in the research are advised to contact the author for the final version of the publication, or visit the DOI to the publisher's website.

- The final author version and the galley proof are versions of the publication after peer review.

- The final published version features the final layout of the paper including the volume, issue and page numbers.

Link to publication

\footnotetext{
General rights rights.

- You may freely distribute the URL identifying the publication in the public portal. please follow below link for the End User Agreement:

www.umlib.nl/taverne-license

Take down policy

If you believe that this document breaches copyright please contact us at:

repository@maastrichtuniversity.nl

providing details and we will investigate your claim.
}

Copyright and moral rights for the publications made accessible in the public portal are retained by the authors and/or other copyright owners and it is a condition of accessing publications that users recognise and abide by the legal requirements associated with these

- Users may download and print one copy of any publication from the public portal for the purpose of private study or research.

- You may not further distribute the material or use it for any profit-making activity or commercial gain

If the publication is distributed under the terms of Article $25 \mathrm{fa}$ of the Dutch Copyright Act, indicated by the "Taverne" license above, 
Molecular signatures and prognosis of HPV-positive head and neck lesions 
Copyright Jeroen Jozef Mooren, Maastricht 2014

Layout: Tiny Wouters

Cover Design: Ipskamp Drukkers

Production: Ipskamp Drukkers

ISBN: 978-94-6259-435-7

Financial support by ALK-Abello, Atos Medical, Beter Horen, Carl Zeiss B.V., Chiesi, Dalecopharma, Dosmedical, EmiD, Entermed, GlaxoSmithKline, Hal Allergy, Laservision Instruments B.V., Meditop, Pentax Nederland B.V., Sanofi Pasteur MSD, Specsavers, Stallergenes, Streukens Hooroplossingen and Vivisol is gratefully acknowledged. 


\title{
Molecular signatures and prognosis of HPV-positive head and neck lesions
}

\author{
PROEFSCHRIFT
}

ter verkrijging van de graad van Doctor aan de Universiteit Maastricht, op gezag van de Rector Magnificus,

Prof. dr. L.L.G. Soete

volgens het besluit van het College van Decanen,

in het openbaar te verdedigen

op dinsdag 16 december 2014 om 14.00 uur

door

Jeroen Jozef Mooren 


\section{Promotores:}

Prof. dr. B. Kremer

Prof. dr. E.J.M. Speel

Prof. dr. F.C.S. Ramaekers

\section{Beoordelingscommissie:}

Prof. dr. J. Geraedts (voorzitter)

Prof. dr. A.J.M. Balm (NKI-AVL, Amsterdam)

Prof. dr. H. zur Hausen (Deutsches Krebsforschungszentrum, Heidelberg)

Dr. M. Lacko

Prof. dr. P.H.M. Savelkoul 


\section{Contents}

$\begin{array}{lll}\text { Chapter } 1 & \text { General introduction and outline of the thesis } & 7\end{array}$

Chapter $2 \quad \mathrm{P} 16^{\mathrm{INK} 4 \mathrm{~A}}$ immunostaining is a strong indicator for 29 high-risk HPV-associated oropharyngeal carcinomas and dysplasias, but is unreliable to predict low-riskHPV-infection in head and neck papillomas and laryngeal dysplasias

Chapter 3 P21 $1^{\text {Cip1/WAF1 }}$ expression is strongly associated with HPVpositive tonsillar carcinoma and a favorable prognosis

Chapter 4 Genetic signatures of HPV-related and unrelated 75 oropharyngeal carcinoma and their prognostic implications

Chapter 5 Chromosome stability in tonsillar squamous cell carcinoma is associated with HPV16 integration and indicates a favourable prognosis

Chapter 6 EGFR expression predicts unfavourable survival in advanced HPV-positive oropharyngeal cancer treated with chemoradiation

Chapter 7 General discussion and conclusion

Summary

Samenvatting

Valorisation addendum

List of publications

Dankwoord

Curriculum Vitae 


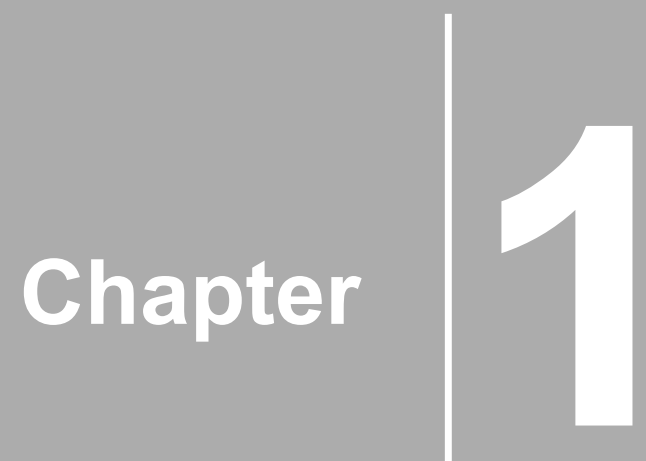

GENERAL INTRODUCTION 
The epithelium in the different anatomical sites of the human head and neck region, including the oral and nasal cavity, the larynx as well as the naso-, oroand hypopharynx (Figure 1.1) can undergo malignant transformation. Most head and neck carcinomas originate from the squamous epithelium forming the head and neck squamous cell carcinomas (HNSCC). These account for $6.5 \%$ of all annual cancer cases worldwide with a wide variation, ranging from $4 \%$ of all malignancies in the Western world up to $50 \%$ in Southeast Asian countries. ${ }^{1}$ In 2008 HNSCC were estimated to cause more than 630,000 new cancer cases and 350,000 cancer deaths worldwide. ${ }^{1}$ It is more often diagnosed in men than in women and particularly after the age of 50 years. In the Netherlands, an average of 2640 new head and neck cancer patients were diagnosed annually in the period between 2000 and 2010, excluding dermal and thyroid carcinomas. An increase in incidence from 2483 tumours in 2000 to 2857 in 2010 was observed. ${ }^{2}$ The most affected sites are the oral cavity, followed by the larynx, and the oro- and hypopharynx, with an average incidence of 882,701 and 563 cases per year, respectively, in this time period. ${ }^{2}$ HNSCC are associated with severe disease- and treatment-related morbidity. The treatment success rates have not improved significantly in recent years, resulting in an almost unaltered 5 -year survival rate of approximately $50 \% .^{3-5}$ Smoking and alcohol consumption are the main causative factors for the development of HNSCC with a synergistic effect when combined. ${ }^{6,7}$ These factors are also responsible for the process of 'field cancerization' in the entire head and neck region, ${ }^{8}$ leading to multiple (pre)neoplastic fields that eventually may develop into multiple primary tumours in up to $40 \%$ of the patients. ${ }^{8-10}$ In the western world a decline of tobacco use has been observed over the last decades. ${ }^{11}$ Because of the robust relationship between tobacco consumption and HNSCC, it was anticipated that the incidence of HNSCC would begin to decrease a few decades after the decline in tobacco use. Available cancer statistics from the United States indeed reveal a steady decrease since the early 1980s in the age-adjusted incidence rates of carcinomas of the larynx, floor of mouth, gingiva, and most other oral cavity sites. In contrast, the ageadjusted incidence of oropharyngeal squamous cell carcinoma (OPSCC) is increasing with about $5 \%$ annually over recent years. This increase is primarily observed in middle-aged (40-59 years) men. ${ }^{12}$

Nodal $(\mathrm{N})$ status is known to be an important prognostic factor in HNSCC. Nodal involvement reduces survival by more than 50\%. ${ }^{13-18}$ However, the prognostic value of $\mathrm{N}$-status is becoming increasingly controversial, in particular for tonsillar squamous cell carcinomas (TSCC), a subgroup of OPSCC. ${ }^{3,19,20}$ These observations suggest heterogeneity in the etiological factors underlying tumourigenesis in different areas of the head and neck mucosa. ${ }^{21}$ In recent years, it has become clear that a subgroup of HNSCC, 
particularly those arising from the oropharynx, is caused by infection with highrisk (HR) types of human papillomavirus (HPV).

\section{Anatomy of the oropharynx}

The pharynx is the part of the digestive tract behind the nasal cavities, mouth, and larynx (Figure 1.1). It reaches from the base of the skull to the lower level of the cricoid cartilage. The pharynx is divided into 3 anatomical subregions, i.e. the nasopharynx, oropharynx and hypopharynx. The oropharynx reaches from the lower border of the soft palate to the level of the hyoid bone and is cranially connected to the nasopharynx and caudally to the hypopharynx. It communicates anteriorly through the isthmus faucium with the mouth, while in its lateral walls, between the two palatine arches, the palatine tonsils are located (Figure 1.2). These are part of the Waldeyer's ring of lymphoid tissue found in the pharynx, which provides defence against bacteria, viruses and fungi entering through the mouth and nose. A fibrous tissue capsule surrounds the palatine tonsils. The tonsillar epithelium exhibits branched deep indentations, forming the tonsillar crypts that increase the contact surface between the lymphoepithelium and the oropharyngeal cavity (Figure 1.3).

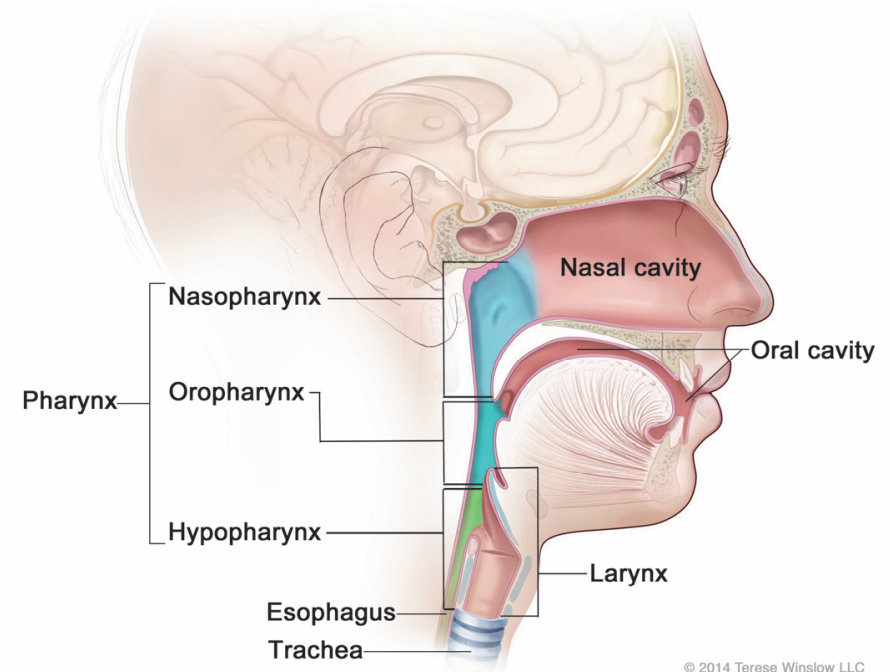

Figure 1.1 Lateral view of the main anatomical sites in the head and neck region. 


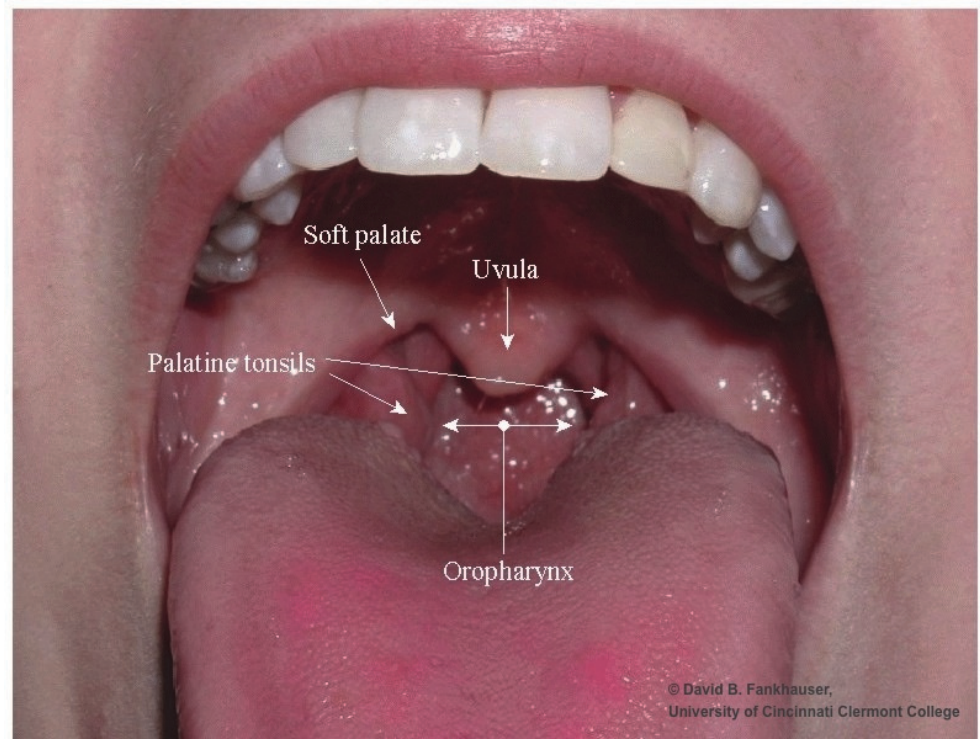

Figure 1.2 Frontal view of the oral cavity.

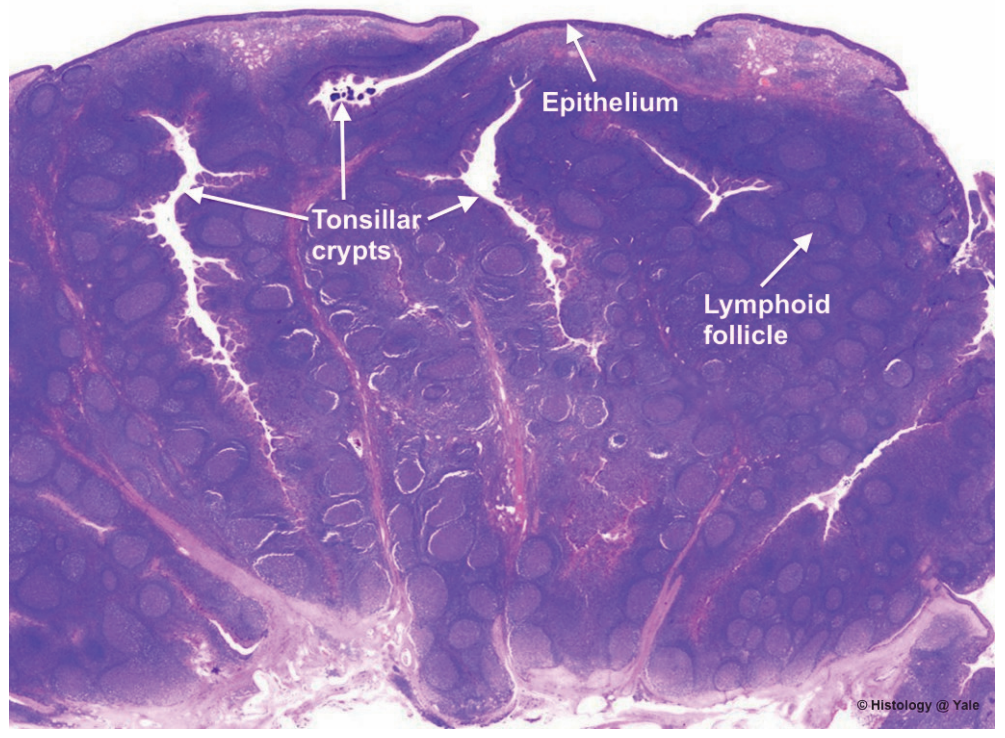

Figure 1.3 Normal histology of tonsil showing the deep indentations of the crypts. 


\section{Head and neck carcinogenesis}

HNSCC develops through a series of well-defined histological stages (Figure 1.4), reflecting the multistep process of carcinogenesis. First, a hyperplastic lesion may form with an abnormal increase in cell number, in which the cells remain subject to normal regulatory control mechanisms resulting in a relatively normal differentiation behaviour and normal cell morphology. Because of accumulation of DNA-damage a hyperplastic lesion may proceed to dysplasia, characterized by cellular atypia and loss of normal maturation. The next step in this process leads to carcinoma in situ (CIS), in which the whole thickness of the epithelium is occupied by tumour cells, but without stromal invasion. Finally, after invasion of the stromal compartment, the lesion is classified as invasive carcinoma. At this stage tumour cells may invade blood vessels and the lymphoid system, leading to the formation of regional and distant metastases.

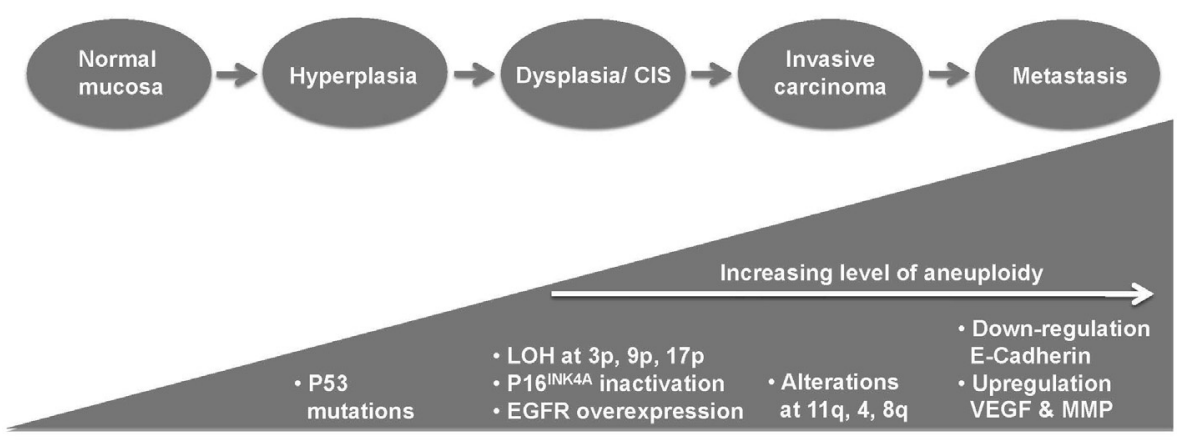

Figure 1.4 Histological stages of HNSCC development with the major molecular stages indicated.

HNSCC development is associated with the acquisition of genetic and epigenetic changes that deregulate genes resulting in cancer related characteristics, including limitless replicative potential, self-sufficiency in growth signals, insensitivity to anti-growth signals, ability to evade apoptosis, invasion and metastasis, and angiogenesis. ${ }^{22-24}$ One of the initial steps include alterations in the p53 tumour suppressor gene, which may play a role in the development of hyperplasia. ${ }^{23}$ Loss of heterozygosity at chromosomes $3 p, 9 p$ and $17 p$ can be found in dysplasia, apparently reflecting early carcinogenesis and resulting in inactivation of tumour suppressor genes, such as $\mathrm{p} 16^{\mathrm{INK} 4 \mathrm{~A}}$. Changes in the expression levels or structure of epidermal growth factor receptor (EGFR) are also observed in dysplastic lesions. Alterations at chromosomes $11 \mathrm{q}, 4 \mathrm{q}$ and chromosome 8 are typically found in carcinomas, representing late phase changes in carcinogenesis. ${ }^{24}$ The accumulation of 
chromosomal aberrations will lead to an increasing level of aneuploidy throughout the process of carcinogenesis. Several biomarkers detecting aneuploidy have been successfully used to predict transition from precancer to cancer. $^{25,26,27}$

Finally, several genes, including those encoding E-Cadherin, vascular endothelial growth factor (VEGF) and matrix metalloproteinases (MMPs) have been associated with the formation of metastases. ${ }^{23}$

In case HPV is involved in the aetiology of head and neck cancer, processes such as cell cycle regulation and apoptosis are compromised through the intervention of HPV with the functioning of p53 and the retinoblastoma protein $(p R b)$ in particular (see below).

\section{Human papillomaviruses}

HPVs are nonenveloped viruses containing a genome of circular doublestranded DNA of approximately $8 \mathrm{~kb}$. They are highly epitheliotropic and known to infect both mucosal and cutaneous epithelia. ${ }^{5}$ The circular HPV-DNA comprises 8 genes and a long control region (LCR). The genes are grouped into early genes (E1, E2, E4, E5, E6, E7), expression of which is necessary for viral replication, and late genes (L1 and L2), which encode the major and minor capsid proteins (Figure 1.5). The functions of these viral proteins are summarised in Table 1.1. In productive infections the expression status of these genes is dependent on the stage of the HPV life cycle.

Table 1.1 The main functions of the HPV proteins. ${ }^{28-30}$

\begin{tabular}{lll}
\hline HPV protein & Function & Temporal expression \\
\hline E1 & Viral replication, DNA helicase & $\begin{array}{l}\text { Early (prior to productive } \\
\text { viral replication) }\end{array}$ \\
E2 & Transcriptional regulator & Early \\
E4 & Destabilisation of cytokeratin network & Early and late \\
E5 & Mediates mitogenic signalling of growth factors & Early and late \\
E6 & Major oncoprotein interacting with p53 leading to its & Early \\
E7 & ubiquitination and proteasomal degradation & \\
L1 & Major oncoprotein interacting with and inactivating & Early \\
& Major viral capsid protein & Late (at the time of \\
L2 & Minor viral capsid protein & Late
\end{tabular}


Up to now approximately 130 HPV-types have been classified. A subgroup of 15 HPV-types is considered to be oncogenic and are therefore designated HR-HPVs. These are mainly linked to development of malignant lesions of mucosal epithelia and include HPV16, -18, -31, -33, -35, -39, -45, -51, -52, -56, $-58,-59,-68,-73$, and $-82 .{ }^{31}$ All HR-HPVs belong to the alpha-genus. HPV16 and HPV 18 are found in $\sim 50 \%$ and $\sim 20 \%$ of uterine cervical malignancies, respectively. ${ }^{32}$ Differences in the capacity to deregulate cellular protein function through the viral oncogenes E6 and E7 distinguish HR-HPV from low-risk (LR)-HPV with respect to their carcinogenic properties. LR-HPV-types, such as HPV6 and HPV11, are often found in benign mucosal lesions and are only sporadically associated with carcinomas. ${ }^{33-35}$

\section{Deregulation of the cell cycle by HPV}

The viral oncoproteins E6 and E7 have a direct effect on several essential cellular processes, such as cell cycle and apoptosis. In the majority of cases HPV maintains an episomal state, and infection with HPV is transient. Persistent infection may lead to integration of the virus into the host genome, generally resulting in disruption of the E1/E2 open reading frame, described to result in the absence of the E2 function and upregulation of the viral oncoproteins $\mathrm{E} 6$ and $\mathrm{E} 7 .^{5,36} \mathrm{E} 6$ and $\mathrm{E} 7$ inactivate p53 and pRb, respectively, leading to disruption of cell cycle regulation and of the apoptotic pathway (Figure 1.5).

Several studies, however, also found HPV16-positive OPSCC and cervical cancers to carry HPV in its episomal form, without proof of integrated viral DNA. ${ }^{37,38}$ This may be the true situation, or caused by the inability to detect the viral integration by the used PCR technologies and choice of primer sets, ${ }^{39}$ or the presence of uninterrupted episomal copies in concatenation in the viral integration sites. ${ }^{38,40}$ Irrespective of information of the physical status of the virus, a recent study provided evidence that E6 and E7 oncogenes are constitutively expressed in HPV16-positive OPSCC. ${ }^{38}$

Cell cycle control proteins that are involved in the oncogenic process include the cyclin dependent kinase (CDK)/cyclin D1 system, which controls the activity of $\mathrm{pRb}$. During $\mathrm{G} 1$ phase of the cell cycle, $\mathrm{pRb}$ binds the transcription factor $\mathrm{E} 2 \mathrm{~F}$ and blocks the transcription of S-phase genes. When cells are stimulated to divide by extracellular signals, active CDK4-6/cyclin D1 complex accumulates and phosphorylates $\mathrm{pRb}$, reducing its affinity for E2F. The $\mathrm{pRb}-\mathrm{E} 2 \mathrm{~F}$ interaction then dissociates, which allows E2F to activate S-phase gene expression. ${ }^{41}$ Upon HPV-infection the HPV-E7 protein binds to unphosphorylated $p R b$, again leading to its inactivation and release of E2F, which then activates the cell cycle and DNA-replication (Figure 1.6). ${ }^{42-44}$ 


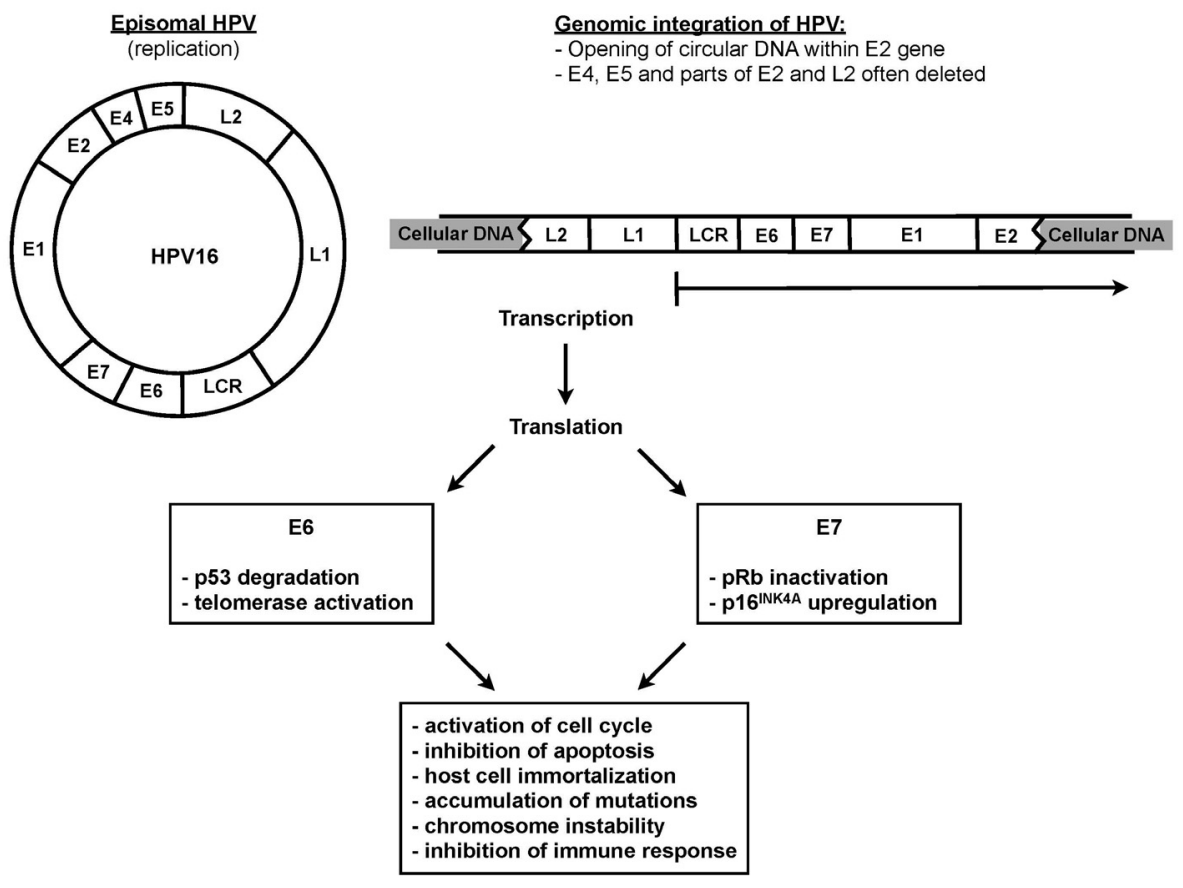

Figure 1.5 Schematic representation of the genomic structure of episomal and intergrated HPV and the effect of E6-E7 overexpression.

CDKN2A is an important tumour suppressor gene, the gene product ( $\left.\mathrm{p} 16^{\mathrm{INK} 4 \mathrm{~A}}\right)$ of which inhibits the catalytic activity of the CDK4-6/cyclin D1 complex. This prevents phosphorylation of $\mathrm{pRb}$ and thereby progression of the cell into the $\mathrm{S}$-phase. Simultaneously, $\mathrm{pRb}$ is a negative regulator of $\mathrm{p} 16^{\mathrm{INK} 4 \mathrm{~A}}$ and therefore, in HPV-induced carcinomas, $\mathrm{p} 16^{\mathrm{INK} 4 \mathrm{~A}}$ is overexpressed due to the inactivation of $p R b$ by $E 7 .^{45} A$ recent report suggests that HPV-E7 induces epigenetic alterations, such as KDM6A and KDM6B histone demethylase expression, that result in upregulation of $\mathrm{p} 16^{\mathrm{INK} 4 \mathrm{~A}}$ expression. ${ }^{46}$

In contrast, tobacco and alcohol induced HNSCC often show loss of chromosome $9 \mathrm{p} 21$, leading to inactivation of $\mathrm{p} 16^{\mathrm{INK} 4 \mathrm{~A}}$ and its inhibitory function and in this way to cell cycle progression. ${ }^{47-49}$

The p53 protein has important functions in cell cycle arrest and induction of apoptosis. Under normal circumstances, p53 is dormant until activated upon DNA damage or as a result of other genomic aberrations. P53, which is then phosphorylated and stabilized, activates on the one hand the transcription of the $\mathrm{p} 21^{\mathrm{CIP} 1 / \mathrm{WAF} 1}$ gene resulting in the arrest of the cell cycle in $\mathrm{G} 1$ and allowing for DNA repair. On the other hand p53 induces apoptosis by gradually 
increasing the level of the pro-apoptotic BCL2 family proteins. Disruption of the p53 pathway through gene mutation, protein inactivation, or modification is known to occur in more than $50 \%$ of HNSCC cases. The lack of functional p53 allows continued replication of abnormal cells, not undergoing apoptosis, leading to an accumulation of genetic changes that contribute to malignant progression. ${ }^{50}$ HPV-E6 promotes degradation of p53 through interaction with E6-associated protein (E6-AP), leading to E3 ubiquitin ligase activity, and subsequent ubiquitination and proteasomal degradation of p53. This results in cell survival and ultimately in genetic instability. ${ }^{51,52}$

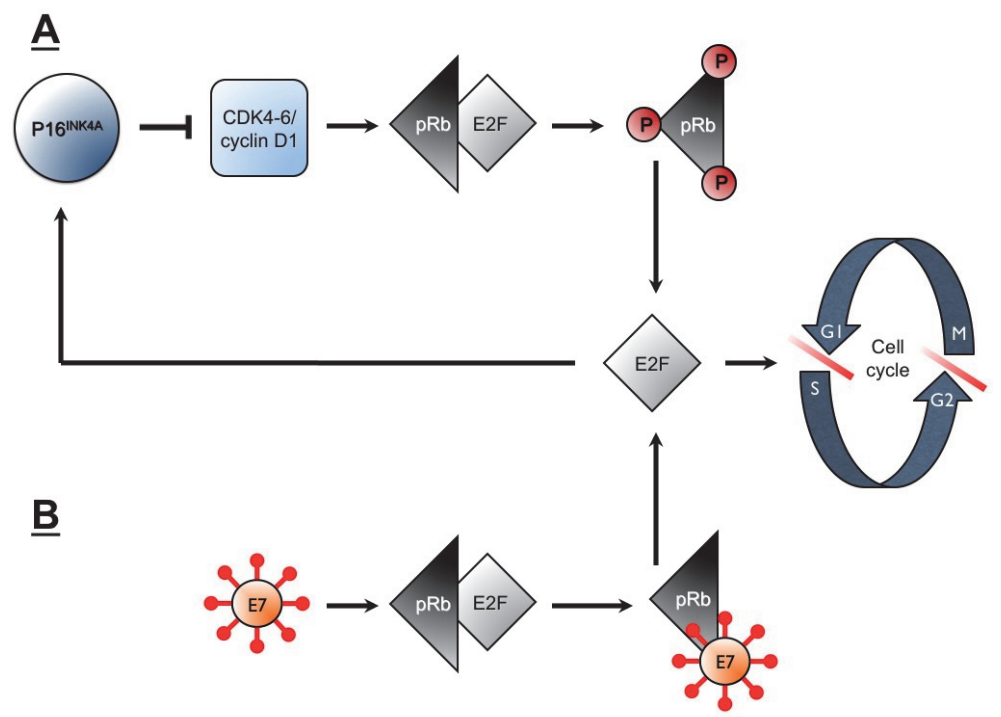

Figure 1.6 pRb deregulation by HPV-E7. A) pRb normally binds the E2F transcription factor and keeps it inactive. Upon activation of the cell cycle, CDK4-6/cyclin D1 complexes phosphorylate $(\mathrm{P}) \mathrm{pRb}$, resulting in the release of E2F and ultimately in the initiation of the S-phase. P16 ${ }^{\text {INK4A }}$ inhibits CDK4-6/cyclin D1 complexes and thereby $\mathrm{pRb}$ phosphorylation. In a feedback loop E2F stimulates $\mathrm{p} 16^{\mathrm{INK} 4 \mathrm{~A}}$ expression, thereby inhibiting further release of E2F. B) Upon HPV-infection the HPV-E7 protein binds to $\mathrm{pRb}$, leading to its inactivation and the release of E2F, which then activates the cell cycle and causes overexpression of $\mathrm{p} 16^{\mathrm{INK} 4 \mathrm{~A}}$.

\section{HPV as etiological factor in OPSCC}

Numerous studies have shown an etiological relationship between HR-HPV infections and the development of uterine cervical and other anogenital carcinomas. More than $90 \%$ of the cervical cancers contain and express HR-HPV sequences, which are often integrated into the host genome. 
HPV-type 16 is most common, detected in more than $50 \%$ of cervical cancers, followed by HPV-types 18,33 and 45 . $^{5,53}$

The involvement of HR-HPV in head and neck carcinogenesis was first proposed by Syrjänen et al. ${ }^{54}$ It is now well established that particularly HPV16 plays an important carcinogenic role in OPSCC, and particularly in TSCC, with a reported incidence of HPV-positive cases ranging from $25 \%$ to $93 \%$ in different studies. ${ }^{5,54-56}$ Similar to what has been observed in the uterine cervix, also in OPSCC HR-HPV is often found in an integrated form. The reason for the strong association of HPV with TSCC, and thus the susceptibility of tonsils for HPV-infection, remains unclear. Explanations that have been suggested include the fact that the invaginated, monolayered crypt epithelium is easily accessible for the virus, and secondly that the presence of cytokines produced by the lymphoid tissue may stimulate viral transcription and cellular transformation. ${ }^{57-59}$ Because studies on premalignant tonsillar lesions are scarce, because patients usually enter the clinic with invasive tumours, the association between HPV and the different histological steps of carcinogenesis less clear than in uterine cervical carcinoma. Detailed, epidemiological data concerning the ordinary course of HR-HPV-infection in the oropharynx are unavailable at present, because premalignant lesions of the tonsils are scarcely observed in the clinic. ${ }^{6}$

\section{HPV-positive OPSCC: a separate entity}

HPV-positive HNSCC is considered to be a different tumour entity when compared to HPV-negative HNSCC, based on prominent biological and epidemiological differences.

Clinically it has been reported that HPV-positive tumours occur most frequently in the oropharynx. Most patients with HPV-positive OPSCC are younger, less likely to have a history of tobacco and alcohol use and have a higher number of sexual partners, in particular oral sex partners, than patients with HPV-negative OPSCC. Furthermore, survival is markedly better for patients with HPV-positive OPSCC, despite the fact that these cases often present as poorly differentiated tumours, and metastasize to the lymph nodes in the neck at earlier tumour $(T)$ stages. ${ }^{3,21,55}$ A possible explanation for the better survival of HPV-positive tumours may be an earlier detection of HPV-positive primary tumours because of an earlier clinical presentation of a lymph node metastasis in this group. As previously described in the literature, ${ }^{3}$ we indeed observed a relationship between a swelling in the neck as presenting symptom on the one hand and the presence of HPV in the primary tumour on the other. This pattern of regional tumour spreading in smaller primary tumour sizes may contribute to an earlier detection of an unknown primary tumour. According to this hypothesis, 
the tumour biology of HPV-positive tumours with earlier lymphogenic spread would result in the detection of smaller tumours (T1-T2). ${ }^{21}$ Furthermore, in our study, ${ }^{21}$ we have shown that in HPV-positive OPSCC nodal involvement ameliorates outcome, while in HPV-negative OPSCC nodal involvement has a negative influence on the prognosis, the latter being in line with the classic correlation of this prognostic factor with outcome.

Multiple hypotheses trying to explain the better outcome of HPV-positive tumours have been put forward. They are all based on factors related to therapy-outcome and include the absence of field cancerization, an intact apoptotic tumour response to radiation, and an active immune response to viral-specific tumour antigens. In contrast, OPSCC related to tobacco smoking and alcohol consumption do show field cancerization, absence of apoptosis and a poor immune surveillance, resulting in the unfavourable patient outcome. $^{60-63}$

At the molecular level, HPV-positive tumours can be distinguished from smoking/ alcohol induced tumours by the fact the latter often show p53 mutations, no $\mathrm{p} 16^{\mathrm{INK} 4 \mathrm{~A}}$ overexpression, normal $\mathrm{pRb}$ and cyclin D1 levels, overexpression of EGFR and loss of heterozigocity $(\mathrm{LOH}){ }^{5,64}$ Based on these differences, Weinberger et al. $^{65}$ proposed a three-class model for oropharyngeal carcinogenesis, dividing OPSCC as being induced by 1) smoking/ alcohol consumption; 2) HR-HPV-infection, or 3) by initial smoking/ alcohol consumption subsequently followed by HR-HPV-infection, the latter group showing the molecular characteristics of class 1 tumours.

\section{The prevalence of HPV in OPSCC}

Prevalence rates of HPV-positivity in OPSCC show a high regional variability around the world. In Europe, prevalences have been described that range from $20 \%$ in the Netherlands (1997-2002), to 41\% in Switzerland (1998-2003), 55\% in Germany (1997-2005) and 62\% in France (1987-2005). In the United States, prevalence rates are even higher, varying from 64\% (2002-2005) to $72 \%(2000-2006) .{ }^{66}$ The variation may depend on several factors, including differences in sample preparation and HPV-detection technologies, geographical distribution of HR-HPV-types, and lifestyle factors of the examined patient population. ${ }^{5}$ The incidence-figures of HPV-related OPSCC have increased over the last decades. In the Netherlands an increase in the proportion of HPV-positive samples from $5.1 \%$ in 1990 to $29 \%$ in 2010 was observed. ${ }^{66}$ In Sweden a rise in HPV-positive TSCC has been described from $68 \%$ in the period between 2000 and 2002 to $77 \%$ between 2003 and 2005, and even $93 \%$ between 2006 and $2007 .^{67}$ The authors of this study even suggested that an epidemic of a virus-induced carcinoma is at hand, with all 
TSCC being HPV-positive in the near future, similar to the situation in cervical cancers. It has been argued that the reported rise in HPV-prevalence in OPSCC may be attributed to an improved sensitivity of detection. However, sensitivity analyses of the potential sources of bias, i.e. detection methods, sample types, and quality of studies, made it highly unlikely that these are the cause of the observed increase in prevalence rates. ${ }^{68}$

It is therefore more likely that a change in lifestyle contributes to the increase in HPV-positive OPSCC. Well-known risk factors for the development of an HPVpositive OPSCC include a higher lifetime number of vaginal and/ or oral sex partners, more casual sex partners, younger age of first intercourse and unprotected sex. ${ }^{69-71}$ This results in an increased exposure to the virus, while the persistence of oral HPV-infection increases the risk of eventual OPSCC development. Over the last decades the age at sexual debut is decreasing, the number of sexual partners increasing, and oral sex has become more common in younger population as compared with older generations. ${ }^{31}$ Furthermore, populations positive for the human immunodeficiency virus (HIV), resulting in a suppressed immune system, have a much higher prevalence of oral HPV-infection and a higher rate of HPV16-positive tumours than HIV-negative population. ${ }^{31}$ There consists conflicting evidence regarding the relationship between cigarette smoking and alcohol consumption on the one hand, and an HPV-positive HNSCC on the other. Oral HPV-prevalence is increased in current smokers, consistent with the immunosuppressive effect of smoking. ${ }^{72,73}$ Also marijuana smoking does seem to have an association with HPV-positive HNSCC. ${ }^{31}$ In a recent study in the Netherlands, however, smoking patterns and alcohol use remained stable in a cohort of 240 patients in the years 1990-2010, despite a rise in HPV-prevalence from $5 \%$ to $29 \%{ }^{66}$

\section{HPV-detection methods}

Given the distinctive nature of HPV-related OPSCC as a biological and clinical variant, the need for standard HPV-testing in these tumours is urgent and compelling. Knowledge of the HPV-status is therefore compulsory for a meaningful comparison of treatment responses of patients enrolled in clinical trials. Furthermore, HPV-status may soon guide the type and intensity of therapy for patients with OPSCC, with antiviral treatment strategies as a possible adjuvant to the more conventional therapies. ${ }^{74,75}$

Many different assays are available for HPV-detection. ${ }^{76} \mathrm{~A}$ widely accepted test for assessment of HPV-involvement in tumour specimens is detection of HPV-DNA by PCR, to determine HPV-type and viral load. ${ }^{55-57}$ However, this procedure cannot distinguish relevant, transcriptionally active HPV from inactive HPV, and moreover may potentially detect contaminating HPV. For the 
detection of an active viral infection the transcripts of the E6 and E7 oncogenes can be assessed by quantitative reverse transcriptase (RT)-PCR. ${ }^{75,77}$ This analysis is most reliably performed on snap frozen samples, since mRNA isolated from formalin-fixed, paraffin-embedded (FFPE) samples is often of poor quality. For routine applications, therefore, HPV-DNA detection methods are being used. ${ }^{66}$ As an alternative for the PCR procedures the fluorescence in situ hybridization (FISH) protocol can be applied to FFPE samples. Although FISH is a less sensitive method as compared to PCR, it is highly specific and has the advantage to visualise the viral DNA in situ, allowing the distinction between an episomal and integrated status. ${ }^{78}$ Both techniques are relatively costly, technically demanding and require sophisticated laboratory facilities, as well as experienced staff. ${ }^{79}$ Therefore, more practical alternatives or complementary procedures for HPV-testing have been explored, including the immunohistochemical detection of $\mathrm{p} 16^{\mathrm{INK} 4 \mathrm{~A}} .^{80}$ Detection of its overexpression, resulting from E7 induced $\mathrm{pRb}$ inactivation, appears to have a sensitivity of nearly $100 \%{ }^{66}$ However, a previous study on tumour-free palatine tonsils, all proven to be negative for HPV, described $\mathrm{p} 16^{\mathrm{INK} 4 \mathrm{~A}}$ overexpression in a quarter of these normal cases, indicating a tendency towards false-positivity for this assay. ${ }^{81}$ Moreover, studies on OPSCC also described a group of discordant cases, being $\mathrm{p} 16^{\mathrm{INK} 4 \mathrm{~A}}$ positive but HPV-DNA-negative, ${ }^{82,83}$ making its reliability as a surrogate marker for the presence of HR-HPV still subject of debate. 


\section{Aims of the studies described in this thesis}

Since it has become evident over the last decades that infection with HPV is an etiological factor in the development of OPSCC, HPV-positive OPSCC is considered a separate tumour entity, which can be distinguished from HPV-negative tumours on basis of epidemiological and biological factors. The aim of the studies presented in this thesis was to gain insight into the molecular and clinical differences between these two tumour types, and to assess important prognosticators for OPSCC patient survival.

The following questions were addressed:

1) Is $p 16^{I N K 4 A}$ a reliable surrogate marker for the presence of HR- and LR-HPV in head and neck lesions?

To answer this question, a series of OPSCC, as well as benign and dysplastic head and neck lesions have been analyzed by immunohistochemistry for $\mathrm{p} 16^{\mathrm{INK} 4 \mathrm{~A}}$ expression in relation to HPV-status.

2) Can we better differentiate HPV-positive OPSCC from the HPV-negative cases induced by smoking and alcohol abuse, based on new molecular parameters, in addition to the conventional biomarkers?

Therefore, to gain more insight into the process of OPSCC carcinogenesis, studies were performed on cell cycle, cell survival and signal transduction related protein expression patterns, and at the level of chromosomal alterations.

3) Within the HPV-positive OPSCC patient group can we further distinguish the cases with a favourable prognosis from those with a poor disease outcome, using new prognosis related biomarkers?

For this purpose, the cell cycle related protein expression patterns, as well as chromosomal alterations were studied in relation to patient survival.

4) Since HPV-positive OPSCC are known to respond better to chemoradiation therapy (CRT) as compared to HPV-negative cases, can the prognosis associated biomarker EGFR be related to therapy outcome? $?^{84,85}$

In an attempt to answer this question, advanced OPSCC patients, all treated by CRT, were analyzed for HPV-status, EGFR expression and their effect on treatment outcome.

5) Which combination of parameters, next to HPV-status, should be considered in future risk stratification models for personalized care of patients with OPSCC?

To give an answer to this question, the answers to questions 3 and 4 are combined with the recent literature. 


\section{References}

1. Ferlay J, Shin H-R, Bray F, Forman D, Mathers C, Parkin DM. Estimates of worldwide burden of cancer in 2008: GLOBOCAN 2008. Int $J$ Cancer 2010;127:2893-917.

2. Timmermans AJJ, van den Brekel MWM, van der Molen L, Navran A, Nijssen TF, Hilgers FJM. New developments in the treatment and rehabilitation of head and neck cancer in the Netherlands. Ned Tijdschr Geneeskd 2012;156:A5059.

3. Hafkamp HC, Manni JJ, Haesevoets A, Voogd AC, Schepers M, Bot FJ, Hopman AHN, Ramaekers FCS, Speel E-JM. Marked differences in survival rate between smokers and nonsmokers with HPV 16-associated tonsillar carcinomas. Int $J$ Cancer 2008;122:2656-64.

4. Jemal A, Siegel R, Ward E, Hao Y, Xu J, Murray T, Thun MJ. Cancer statistics, 2008. CA Cancer J Clin 2008;58:71-96.

5. Olthof NC, Straetmans JMJAA, Snoeck R, Ramaekers FCS, Kremer B, Speel EJM. Next-generation treatment strategies for human papillomavirus-related head and neck squamous cell carcinoma: where do we go? Rev Med Virol 2012;22: 88-105.

6. Hafkamp HC, Manni JJ, Speel EJ. Role of human papillomavirus in the development of head and neck squamous cell carcinomas. Acta Otolaryngol 2004;124:520-6.

7. Maasland DH, van den Brandt PA, Kremer B, Goldbohm RAS, Schouten LJ. Alcohol consumption, cigarette smoking and the risk of subtypes of head-neck cancer: results from the Netherlands Cohort Study. BMC Cancer 2014;14:187.

8. Braakhuis BJM, Tabor MP, Kummer JA, Leemans CR, Brakenhoff RH. A genetic explanation of Slaughter's concept of field cancerization: evidence and clinical implications. Cancer Res 2003;63:1727-30.

9. Haughey BH, Gates GA, Arfken CL, Harvey J. Meta-analysis of second malignant tumors in head and neck cancer: the case for an endoscopic screening protocol. Ann Otol Rhinol Laryngol 1992;101:105-12.

10. Slaughter DP, Southwick HW, Smejkal W. Field cancerization in oral stratified squamous epithelium; clinical implications of multicentric origin. Cancer 1953;6: 963-8.

11. de Bruin-Visser JC, Ackerstaff AH, Rehorst H, Retèl VP, Hilgers FJM. Integration of a smoking cessation program in the treatment protocol for patients with head and neck and lung cancer. European Archives of Oto-Rhino-Laryngology 2012;269: 659-65.

12. Ang KK, Sturgis EM. Human papillomavirus as a marker of the natural history and response to therapy of head and neck squamous cell carcinoma. Semin Radiat Oncol 2012;22:128-42.

13. Kalnins IK, Leonard AG, Sako K, Razack MS, Shedd DP. Correlation between prognosis and degree of lymph node involvement in carcinoma of the oral cavity. Am J Surg 1977;134:450-4.

14. Ono I, Ebihara S, Saito H, Yoshizumi T. Correlation between prognosis and degree of lymph node involvement in carcinoma of the head and neck. Auris Nasus Larynx 1985;12 Suppl 2:S85-9.

15. Jakobsen J, Hansen O, Jørgensen KE, Bastholt L. Lymph node metastases from laryngeal and pharyngeal carcinomas--calculation of burden of metastasis and its impact on prognosis. Acta Oncol 1998;37:489-93. 
16. Kehrl W, Wenzel S, Niendorf A. Effect of various forms of metastatic lymph node involvement on prognosis of squamous epithelial carcinomas of the upper aerodigestive tract. Laryngorhinootologie 1998;77:569-75.

17. Ganzer U, Meyer-Breiting E, Ebbers J, Vosteen KH. Effect of tumor size on lymph node metastasis and type of treatment on the prognosis of hypopharyngeal cancer. Laryngol Rhinol Otol (Stuttg) 1982;61:622-8.

18. Leemans CR, Tiwari RM, van der Waal I, Karim AB, Nauta JJ, Snow GB. Neck lymph node dissection in squamous cell carcinoma originating in the head-andneck area; the significance for the prognosis. Ned Tijdschr Geneeskd 1992;136: 221-5.

19. Friesland S, Fernberg JO, Lundell G, Munck-Wikland E, Strander H, Lewensohn R. Prognostic impact of complete remission after preoperative irradiation of tonsillar carcinoma: a retrospective analysis of the radiumhemmet data, 1980-1995. Int J Radiat Oncol Biol Phys 1999;45:1259-66.

20. al-Abdulwahed S, Kudryk W, al-Rajhi N, Hanson J, Jenkins H, Gaedke H, Jha N. Carcinoma of the tonsil: prognostic factors. J Otolaryngol 1997;26:296-9.

21. Straetmans JM, Olthof N, Mooren JJ, de Jong J, Speel EJ, Kremer B. Human papillomavirus reduces the prognostic value of nodal involvement in tonsillar squamous cell carcinomas. Laryngoscope 2009;

22. Hanahan D, Weinberg RA. Hallmarks of cancer: the next generation. Cell 2011; 144:646-74.

23. Haddad RI, Shin DM. Recent advances in head and neck cancer. N Engl J Med 2008;359:1143-54.

24. Leemans CR, Braakhuis BJM, Brakenhoff RH. The molecular biology of head and neck cancer. Nat Rev Cancer 2010;11:9-22.

25. Siebers TJH, Bergshoeff VE, Otte-Holler I, Kremer B, Speel EJM, van der Laak JAWM, Merkx MAW, Slootweg PJ. Chromosome instability predicts the progression of premalignant oral lesions. Oral Oncology 2013;49:1121-8.

26. Zhang L, Poh CF, Williams M, Laronde DM, Berean K, Gardner PJ, Jiang H, Wu L, Lee JJ, Rosin MP. Loss of heterozygosity ( $\mathrm{LOH}$ ) profiles--validated risk predictors for progression to oral cancer. Cancer Prev Res (Phila) 2012;5:1081-9.

27. Bergshoeff VE, Van der Heijden SJA, Haesevoets A, Litjens SGH, Bot FJ, Voogd AC, Chenault MN, Hopman AHN, Schuuring E, Van der Wal JM, Manni JJ, Ramaekers FCS, et al. Chromosome instability predicts progression of premalignant lesions of the larynx. Pathology 2014;46:216-24.

28. Korzeniewski N, Spardy N, Duensing A, Duensing S. Genomic instability and cancer: lessons learned from human papillomaviruses. Cancer Lett 2011;305: 113-22.

29. Khan J, Davy CE, McIntosh PB, Jackson DJ, Hinz S, Wang Q, Doorbar J. Role of calpain in the formation of human papillomavirus type $16 \mathrm{E} 1^{\wedge} \mathrm{E} 4$ amyloid fibers and reorganization of the keratin network. J Virol 2011;85:9984-97.

30. Mclntosh PB, Laskey P, Sullivan K, Davy C, Wang Q, Jackson DJ, Griffin HM, Doorbar J. E1--E4-mediated keratin phosphorylation and ubiquitylation: a mechanism for keratin depletion in HPV16-infected epithelium. J Cell Sci 2010;123: 2810-22.

31. Zandberg DP, Bhargava R, Badin S, Cullen KJ. The role of human papillomavirus in nongenital cancers. CA Cancer J Clin 2013;63:57-81. 
32. Muñoz N, Bosch FX, de Sanjosé S, Herrero R, Castellsagué X, Shah KV, Snijders PJF, Meijer CJLM, International Agency for Research on Cancer Multicenter Cervical Cancer Study Group. Epidemiologic classification of human papillomavirus types associated with cervical cancer. N Engl J Med 2003;348:518-27.

33. Hiller T, Poppelreuther S, Stubenrauch F, Iftner T. Comparative analysis of 19 genital human papillomavirus types with regard to p53 degradation, immortalization, phylogeny, and epidemiologic risk classification. Cancer Epidemiol Biomarkers Prev 2006;15:1262-7.

34. Pim D, Banks L. Interaction of viral oncoproteins with cellular target molecules: infection with high-risk vs low-risk human papillomaviruses. APMIS 2010;118: 471-93.

35. Huebbers CU, Preuss SF, Kolligs J, Vent J, Stenner M, Wieland U, Silling S, Drebber U, Speel E-JM, Klussmann JP. Integration of HPV6 and Downregulation of AKR1C3 Expression Mark Malignant Transformation in a Patient with JuvenileOnset Laryngeal Papillomatosis. PLoS ONE 2013;8:e57207.

36. Mellin H, Dahlgren L, Munck-Wikland E, Lindholm J, Rabbani H, Kalantari M, Dalianis T. Human papillomavirus type 16 is episomal and a high viral load may be correlated to better prognosis in tonsillar cancer. Int J Cancer 2002;102:152-8.

37. Watts KJ, Thompson CH, Cossart YE, Rose BR. Sequence variation and physical state of human papillomavirus type 16 cervical cancer isolates from Australia and New Caledonia. Int J Cancer 2002;97:868-74.

38. Olthof NC, Speel E-JM, Kolligs J, Haesevoets A, Henfling M, Ramaekers FCS, Preuss SF, Drebber U, Wieland U, Silling S, Lam WL, Vucic EA, et al. Comprehensive Analysis of HPV16 Integration in OSCC Reveals No Significant Impact of Physical Status on Viral Oncogene and Virally Disrupted Human Gene Expression. PLOS ONE 2014;9:e88718.

39. Li H, Yang Y, Zhang R, Cai Y, Yang X, Wang Z, Li Y, Cheng X, Ye X, Xiang Y, Zhu B. Preferential sites for the integration and disruption of human papillomavirus 16 in cervical lesions. J Clin Virol 2013;56:342-7.

40. Akagi K, Li J, Broutian TR, Padilla-Nash H, Xiao W, Jiang B, Rocco JW, Teknos TN, Kumar B, Wangsa D, He D, Ried T, et al. Genome-wide analysis of HPV integration in human cancers reveals recurrent, focal genomic instability. Genome Res 2014;24:185-99.

41. Andl T, Kahn T, Pfuhl A, Nicola T, Erber R, Conradt C, Klein W, Helbig M, Dietz A, Weidauer $\mathrm{H}$, Bosch FX. Etiological involvement of oncogenic human papillomavirus in tonsillar squamous cell carcinomas lacking retinoblastoma cell cycle control. Cancer Res 1998;58:5-13.

42. Funk JO, Waga S, Harry JB, Espling E, Stillman B, Galloway DA. Inhibition of CDK activity and PCNA-dependent DNA replication by $\mathrm{p} 21$ is blocked by interaction with the HPV-16 E7 oncoprotein. Genes \& Development 1997;11:2090-100.

43. Jones DL, Alani RM, Munger K. The human papillomavirus E7 oncoprotein can uncouple cellular differentiation and proliferation in human keratinocytes by abrogating p21Cip1-mediated inhibition of cdk2. Genes \& Development 1997;11: 2101-11.

44. Zerfass-Thome K, Zwerschke W, Mannhardt B, Tindle R, Botz JW, Jansen-Dürr P. Inactivation of the cdk inhibitor p27KIP1 by the human papillomavirus type 16 E7 oncoprotein. Oncogene 1996;13:2323-30. 
45. Klussmann JP, Gültekin E, Weissenborn SJ, Wieland U, Dries V, Dienes HP, Eckel $\mathrm{HE}$, Pfister HJ, Fuchs PG. Expression of p16 protein identifies a distinct entity of tonsillar carcinomas associated with human papillomavirus. Am J Pathol 2003;162: 747-53.

46. McLaughlin-Drubin ME, Crum CP, Münger K. Human papillomavirus E7 oncoprotein induces KDM6A and KDM6B histone demethylase expression and causes epigenetic reprogramming. Proc Natl Acad Sci USA 2011;108:2130-5.

47. Rocco JW, Sidransky D. p16(MTS-1/CDKN2/INK4a) in cancer progression. Exp Cell Res 2001;264:42-55.

48. Shintani S, Nakahara $Y$, Mihara M, Ueyama $Y$, Matsumura T. Inactivation of the p14(ARF), p15(INK4B) and p16(INK4A) genes is a frequent event in human oral squamous cell carcinomas. Oral Oncol 2001;37:498-504.

49. Yamato K, Hashimoto S, Okahashi N, Ishisaki A, Nonaka K, Koseki T, Kizaki M, Ikeda Y, Nishihara T. Dissociation of bone morphogenetic protein-mediated growth arrest and apoptosis of mouse B cells by HPV-16 E6/E7. Exp Cell Res 2000;257:198-205.

50. Li W, Thompson CH, Cossart YE, O'Brien CJ, McNeil EB, Scolyer RA, Rose BR. The expression of key cell cycle markers and presence of human papillomavirus in squamous cell carcinoma of the tonsil. Head Neck 2004;26:1-9.

51. McMurray HR, McCance DJ. Human papillomavirus type 16 E6 activates TERT gene transcription through induction of c-Myc and release of USF-mediated repression. Journal of Virology 2003;77:9852-61.

52. Liu X, Dakic A, Zhang Y, Dai Y, Chen R, Schlegel R. HPV E6 protein interacts physically and functionally with the cellular telomerase complex. Proc Natl Acad Sci USA 2009;106:18780-5.

53. Hausen zur H. Papillomaviruses and cancer: from basic studies to clinical application. Nat Rev Cancer 2002;2:342-50.

54. Syrjänen K, Syrjänen S, Lamberg M, Pyrhönen S, Nuutinen J. Morphological and immunohistochemical evidence suggesting human papillomavirus (HPV) involvement in oral squamous cell carcinogenesis. Int J Oral Surg 1983;12:418-24.

55. Gillison ML, Koch WM, Capone RB, Spafford M, Westra WH, Wu L, Zahurak ML, Daniel RW, Viglione M, Symer DE, Shah KV, Sidransky D. Evidence for a causal association between human papillomavirus and a subset of head and neck cancers. J Natl Cancer Inst 2000;92:709-20.

56. van Houten VM, Snijders PJ, van den Brekel MW, Kummer JA, Meijer CJ, van Leeuwen B, Denkers F, Smeele LE, Snow GB, Brakenhoff RH. Biological evidence that human papillomaviruses are etiologically involved in a subgroup of head and neck squamous cell carcinomas. Int J Cancer 2001;93:232-5.

57. Klussmann JP, Weissenborn SJ, Wieland U, Dries V, Kolligs J, Jungehuelsing M, Eckel HE, Dienes HP, Pfister HJ, Fuchs PG. Prevalence, distribution, and viral load of human papillomavirus 16 DNA in tonsillar carcinomas. Cancer 2001;92: 2875-84.

58. Wilczynski SP, Lin BT, Xie Y, Paz IB. Detection of human papillomavirus DNA and oncoprotein overexpression are associated with distinct morphological patterns of tonsillar squamous cell carcinoma. Am J Pathol 1998;152:145-56.

59. Franceschi S, Muñoz N, Snijders PJ. How strong and how wide is the link between HPV and oropharyngeal cancer? Lancet 2000;356:871-2.

60. Mellin H, Friesland S, Lewensohn R, Dalianis T, Munck-Wikland E. Human papillomavirus (HPV) DNA in tonsillar cancer: clinical correlates, risk of relapse, and survival. Int J Cancer 2000;89:300-4. 
61. Ferris RL, Martinez I, Sirianni N, Wang J, López-Albaitero A, Gollin SM, Johnson JT, Khan S. Human papillomavirus-16 associated squamous cell carcinoma of the head and neck (SCCHN): a natural disease model provides insights into viral carcinogenesis. Eur J Cancer 2005;41:807-15.

62. Lindel K, Beer KT, Laissue J, Greiner RH, Aebersold DM. Human papillomavirus positive squamous cell carcinoma of the oropharynx: a radiosensitive subgroup of head and neck carcinoma. Cancer 2001;92:805-13.

63. DeWeese TL, Walsh JC, Dillehay LE, Kessis TD, Hedrick L, Cho KR, Nelson WG. Human papillomavirus E6 and E7 oncoproteins alter cell cycle progression but not radiosensitivity of carcinoma cells treated with low-dose-rate radiation. Int $J$ Radiat Oncol Biol Phys 1997;37:145-54.

64. Braakhuis BJ, Snijders PJ, Keune WJ, Meijer CJ, Ruijter-Schippers HJ, Leemans $\mathrm{CR}$, Brakenhoff RH. Genetic patterns in head and neck cancers that contain or lack transcriptionally active human papillomavirus. J Natl Cancer Inst 2004;96: 998-1006.

65. Weinberger PM, Yu Z, Haffty BG, Kowalski D, Harigopal M, Brandsma J, Sasaki C, Joe J, Camp RL, Rimm DL, Psyrri A. Molecular classification identifies a subset of human papillomavirus--associated oropharyngeal cancers with favorable prognosis. Journal of Clinical Oncology 2006;24:736-47.

66. Rietbergen MM, Leemans CR, Bloemena E, Heideman DAM, Braakhuis BJM, Hesselink AT, Witte BI, Baatenburg-De Jong RJ, Meijer CJLM, Snijders PJF, Brakenhoff $\mathrm{RH}$. Increasing prevalence rates of HPV attributable oropharyngeal squamous cell carcinomas in the Netherlands as assessed by a validated test algorithm. Int J Cancer 2013;132:1565-71.

67. Näsman A, Attner P, Hammarstedt L, Du J, Eriksson M, Giraud G, Ahrlund-Richter S, Marklund L, Romanitan M, Lindquist D, Ramqvist T, Lindholm J, et al. Incidence of human papillomavirus (HPV) positive tonsillar carcinoma in Stockholm, Sweden: an epidemic of viral-induced carcinoma? Int J Cancer 2009;125:362-6.

68. Mehanna H, Beech T, Nicholson T, El-Hariry I, McConkey C, Paleri V, Roberts S. Prevalence of human papillomavirus in oropharyngeal and nonoropharyngeal head and neck cancer-systematic review and meta-analysis of trends by time and region. Head Neck 2012;35:747-55.

69. D'Souza G, Kreimer AR, Viscidi R, Pawlita M, Fakhry C, Koch WM, Westra WH, Gillison ML. Case-control study of human papillomavirus and oropharyngeal cancer. N Engl J Med 2007;356:1944-56.

70. Gillison ML, D'Souza G, Westra W, Sugar E, Xiao W, Begum S, Viscidi R. Distinct risk factor profiles for human papillomavirus type 16-positive and human papillomavirus type 16-negative head and neck cancers. J Natl Cancer Inst 2008;100:407-20.

71. Joseph AW, D'Souza G. Epidemiology of human papillomavirus-related head and neck cancer. Otolaryngol Clin North Am 2012;45:739-64.

72. Gillison ML, Broutian T, Pickard RKL, Tong Z-Y, Xiao W, Kahle L, Graubard BI, Chaturvedi AK. Prevalence of oral HPV infection in the United States, 2009-2010. JAMA 2012;307:693-703.

73. D'Souza G, Agrawal Y, Halpern J, Bodison S, Gillison ML. Oral sexual behaviors associated with prevalent oral human papillomavirus infection. J Infect Dis 2009;199:1263-9. 
74. Singhi AD, Westra WH. Comparison of human papillomavirus in situ hybridization and p16 immunohistochemistry in the detection of human papillomavirusassociated head and neck cancer based on a prospective clinical experience. Cancer 2010;116:2166-73.

75. Olthof NC, Straetmans JMJAA, Snoeck R, Ramaekers FCS, Kremer B, Speel EJM. Next-generation treatment strategies for human papillomavirus-related head and neck squamous cell carcinoma: where do we go? Rev Med Virol 2012;22: 88-105.

76. Snijders PJF, Heideman DAM, Meijer CJLM. Methods for HPV detection in exfoliated cell and tissue specimens. APMIS 2010;118:520-8.

77. Shi W, Kato H, Perez-Ordonez B, Pintilie M, Huang S, Hui A, OSullivan B, Waldron J, Cummings B, Kim J, Ringash J, Dawson LA, et al. Comparative prognostic value of HPV16 E6 mRNA compared with in situ hybridization for human oropharyngeal squamous carcinoma. Journal of Clinical Oncology 2009;27:6213-21.

78. Hopman AHN, Kamps MA, Smedts F, Speel E-JM, Herrington CS, Ramaekers FCS. HPV in situ hybridization: Impact of different protocols on the detection of integrated HPV. Int J Cancer 2005;115:419-28.

79. Thavaraj S, Stokes A, Guerra E, Bible J, Halligan E, Long A, Okpokam A, Sloan P, Odell E, Robinson M. Evaluation of human papillomavirus testing for squamous cell carcinoma of the tonsil in clinical practice. Journal of Clinical Pathology 2011;64: 308-12.

80. El-Naggar AK, Westra WH. p16 expression as a surrogate marker for HPV-related oropharyngeal carcinoma: A guide for interpretative relevance and consistency. Head Neck 2011;34:459-61.

81. Klingenberg B, Hafkamp HC, Haesevoets A, Manni JJ, Slootweg PJ, Weissenborn SJ, Klussmann JP, Speel E-JM. p16 INK4A overexpression is frequently detected in tumour-free tonsil tissue without association with HPV. Histopathology 2010;56: 957-67.

82. Rietbergen MM, Snijders PJF, Beekzada D, Braakhuis BJM, Brink A, Heideman DAM, Hesselink AT, Witte BI, Bloemena E, Baatenburg-De Jong RJ, René Leemans C, Brakenhoff RH. Molecular characterization of p16-immunopositive but HPV DNA-negative oropharyngeal carcinomas. Int J Cancer 2014;134:2366-72.

83. Holzinger D, Schmitt M, Dyckhoff G, Benner A, Pawlita M, Bosch FX. Viral RNA patterns and high viral load reliably define oropharynx carcinomas with active HPV16 involvement. Cancer Res 2012;72:4993-5003.

84. Ang KK, Berkey BA, Tu X, Zhang H-Z, Katz R, Hammond EH, Fu KK, Milas L. Impact of epidermal growth factor receptor expression on survival and pattern of relapse in patients with advanced head and neck carcinoma. Cancer Res 2002; 62:7350-6.

85. Rubin Grandis J, Melhem MF, Gooding WE, Day R, Holst VA, Wagener MM, Drenning SD, Tweardy DJ. Levels of TGF-alpha and EGFR protein in head and neck squamous cell carcinoma and patient survival. J Natl Cancer Inst 1998;90: 824-32. 


\section{Chapter}

P16 INK4A IMMUNOSTAINING IS A STRONG INDICATOR FOR HIGHRISK-HPV-ASSOCIATED OROPHARYNGEAL CARCINOMAS AND DYSPLASIAS, BUT IS UNRELIABLE TO PREDICT LOWRISK-HPV-INFECTION IN HEAD AND NECK PAPILLOMAS AND LARYNGEAL DYSPLASIAS

Jeroen J Mooren, Sibel E Gültekin, Jos MJAA Straetmans, Annick Haesevoets, Carine J PeutzKootstra, Christian U Huebbers, Hans P Dienes, Ulrike Wieland, Frans CS Ramaekers, Bernd Kremer, ErnstJan M Speel, Jens P Klussmann

International Journal of Cancer 2014;134:2108-2117 


\section{Abstract}

Human papillomavirus (HPV) is a risk factor for the development of benign and malignant mucosal head and neck lesions. P16 ${ }^{\text {INK4A }}$ is often used as a surrogate marker for HPV-infection, although there is still controversy with respect its reliability. Our aim was to determine if $\mathrm{p} 16^{\text {INK4A }}$ overexpression can accurately predict both high-risk and low-risk-HPV-presence in (pre)malignant and benign head and neck lesions. P16 ${ }^{\text {INK4A }}$ immunohistochemistry was performed on paraffin-embedded tissue sections of 162 oropharyngeal squamous cell carcinomas (OPSCC), 14 tonsillar and 23 laryngeal dysplasias, and 20 tonsillar and 27 laryngeal papillomas. PCR, enzyme-immunoassay and FISH analysis were used to assess HPV-presence and type. Of the 162 OPSCC and 14 tonsillar dysplasias, 51 (31\%) and 10 (71\%) were HPV16-positive, respectively. All tonsillar papillomas were HPV-negative and four laryngeal dysplasias and 26 laryngeal papillomas were positive for HPV6 or -11 . P16 ${ }^{\text {INK4A }}$ immunohistochemistry revealed a strong nuclear and cytoplasmic staining in 50 out of 51 HPV16-positive and 5 out of 111 HPV-negative OPSCC $(p<0.0001)$ and in all HPV16-positive tonsillar dysplasias, whereas highly variable staining patterns were detected in the papillomas and laryngeal dysplasias, irrespective of the HPV-status. In addition, the latter lesions generally showed a higher nuclear than cytoplasmic p16 ${ }^{\text {INK4A }}$ immunostaining intensity. In conclusion, our data show that strong nuclear and cytoplasmic p16 $16^{\text {IK4A }}$ overexpression is a reliable surrogate indicator for HPV16 in OPSCC and (adjacent) dysplasias. For HPV6 or -11-positive and HPV-negative benign and premalignant lesions of the tonsil and larynx, however, $\mathrm{p} 16^{\text {INK4A }}$ immunostaining is highly variable and cannot be recommended to predict HPV-presence. 


\section{Introduction}

Human papillomavirus (HPV)-infections may lead to the development of head and neck mucosal lesions. High-risk (HR)-HPV16 is involved in the carcinogenesis of oropharyngeal squamous cell carcinomas (OPSCC) and is an indicator of favourable prognosis, independent of the applied treatment modality. The reported incidence of HPV16 in OPSCC ranges from $25 \%$ to $93 \%$ in different studies, and appears to have increased during the last decade. Also the incidence of OPSCC and its proportion within the total head and neck squamous cell carcinoma (HNSCC) population are increasing. ${ }^{1,2}$ Low-risk (LR)-HPV6 and -11 especially play a role in the development of benign laryngeal lesions. HPV-positivity may help in these lesions to predict a higher risk for recurrence and a lower risk for malignant progression in relation to HPV-negative, smoking-induced laryngeal lesions. ${ }^{3}$

In general, two methods are used for the detection of HPV-DNA in clinical diagnosis and biomedical research, i.e., polymerase chain reaction (PCR)based methods and fluorescence in situ hybridization (FISH). PCR is a highly sensitive method, but may not be able to distinguish biologically and clinically relevant HPV-containing lesions from cases with an extracellular virus contamination. Although FISH is a less sensitive method, it is highly specific and has the advantage to visualise the virus-DNA in situ and allows the distinction between an episomal and integrated status. Because both techniques are relatively costly, technically demanding and requiring sophisticated laboratory facilities as well as experienced personnel, ${ }^{4}$ practical alternatives or complementary procedures for HPV-testing have been explored, including the immunohistochemical detection of $\mathrm{p} 16^{\text {INK4A } 5}$

HPV-positive carcinomas are characterized by overexpression of viral oncoproteins E6 and E7 leading to inactivation of p53 and the retinoblastoma protein $(p R b)$, respectively, thereby inducing cell cycle deregulation and inhibition of apoptosis. As a result, cyclin-dependent kinase (CDK) inhibitors, including $\mathrm{p} 16^{\text {INK4A }}$ and $\mathrm{p} 21^{\mathrm{Cip} 1 \text { NAF1 } 1}$, and the MDM2 inhibitor $\mathrm{p} 14^{\mathrm{ARF}}$ are generally upregulated, which subsequently leads to downregulation of cyclin D1 and inhibition of its complex formation with CDK4. ${ }^{6-9}$ Of these HPV-associated changes in protein expression, $\mathrm{p} 16^{\text {INK4A }}$ overexpression has been reported to be the most reliable surrogate marker for the presence of HR-HPV in OPSCC. ${ }^{6,10-12}$ In contrast, HPV-negative carcinomas, induced by smoking and alcohol consumption, are generally characterized by inactivation of the $\mathrm{p} 16^{\mathrm{INK} 4 \mathrm{~A}}$ gene through loss of $9 p 21$. Therefore, the choice of $\mathrm{p} 16^{\mathrm{INK} 4 \mathrm{~A}}$ immunostaining to distinguish HPV-positive and -negative malignancies is most obvious. ${ }^{6,7,13,14}$ $\mathrm{P} 16^{\mathrm{INK} 4 \mathrm{~A}}$ immunostaining has long been identified as an objective biomarker for HR-HPV-positive (pre)malignancies of the uterine cervix, allowing the unambiguous identification of truly dysplastic cells in biopsies, thereby reducing 
interobserver disagreement and improving diagnostic specificity. ${ }^{6,15,16}$ In contrast, normal cervical epithelium and inflammatory or metaplastic lesions are usually $\mathrm{p} 16^{\text {INK4A }}$ negative, while genital lesions containing LR-HPV6 or -11 often show only weak p16 ${ }^{\text {INK4A }}$ immunostaining. ${ }^{14,17-19}$ Moreover, several studies reported a strong correlation between $\mathrm{p} 16^{\mathrm{INK} 4 \mathrm{~A}}$ immunostaining intensity and frequency of positive cells with increasing severity of the cervical lesion. ${ }^{18,20-22}$ The College of American Pathologists and the American Society for Colposcopy and Cervical Pathology has recently published their recommendations on using $\mathrm{p} 16^{\text {INK4A }}$ immunostaining as a biomarker in lower anogenital squamous lesions, introducing the concept of 'block positivity', defined as continuous strong nuclear or nuclear plus cytoplasmic $\mathrm{p} 16^{\mathrm{INK} 4 \mathrm{~A}}$ staining of the basal cell layer with upward extension. The authors state that this scoring method allows a categorization of precancerous disease when the differential diagnosis is between a premalignancy (-intraepithelial neoplasia (IN) 2 or $-\mathrm{IN} \mathrm{3}$ ) and a mimic of a premalignancy known to be not related to neoplastic risk. Furthermore, it can be used when -IN 2 is in the differential diagnosis to distinguish between a premalignant disease and a low-grade lesion/a non-HPV-associated pathology. As such, the method is used as an adjudication tool for cases in which there is a professional disagreement in histologic specimen interpretation. ${ }^{23}$

Despite the fact that $\mathrm{p} 16^{\mathrm{INK} 4 \mathrm{~A}}$ immunohistochemistry is a low-cost test that can easily be implemented in daily diagnostic practice, its reliability as a surrogate marker for the presence of HR-HPV has been subject of debate. ${ }^{18,24}$ HPV-negative but $\mathrm{p} 16^{\mathrm{INK} 4 \mathrm{~A}}$ positive cases, although small in number, have been described in many series. It has been suggested that this $\mathrm{p} 16^{\text {INK4A }}$ positivity results from $\mathrm{pRb}$ inactivation by means of mechanisms independent of HPV-infection. ${ }^{4-9,25,26}$ Also the lack of standardization of $\mathrm{p} 16^{\text {INK } 4 \mathrm{~A}}$ immunohistochemistry and its evaluation criteria may be a source of misinterpretations. The foregoing arguments have been a reason for hesitation to introduce the p16 ${ }^{\text {INK4A }}$ test into the clinic. ${ }^{15}$

Although numerous studies analyzed the expression of $\mathrm{p} 16^{\mathrm{INK} 4 \mathrm{~A}}$ in $\mathrm{HR}$ - and LR-HPV-associated cervical premalignancies, these data are scarce for pre-malignant and benign head and neck lesions, and therefore the aim of the present study was to determine the usefulness of this biomarker in neoplasms of the oropharynx and larynx. For this purpose we analysed a series of 162 OPSCC as well as a range of tonsillar and laryngeal dysplasias and papillomas, part of which was expected to harbour HR- and LR-HPV-types. 


\section{Materials and methods}

\section{Tumour material and patient data}

Biopsy and resection material was obtained from 227 patients resulting in 246 samples, taken at different moments in time. Since our main goal was to evaluate the potential of $\mathrm{p} 16^{\mathrm{INK} 4 \mathrm{~A}}$ immunostaining patterns as a surrogate marker for HPV in daily routine diagnostic practice, i.e., in every single biopsy sample a pathologist receives from the clinic, we present the analyses in the total number of samples in the main text (Table 2.1 and Figures 2.1A and 2.1B). For comparison we have included the analyses per patient in Supplementary Table S2.1 and Supplementary Figures S2.1A and S2.1B.

Formaldehyde-fixed and paraffin-embedded tissues were selected from the archives of the Departments of Pathology of the University of Cologne, Germany and the Maastricht University Medical Centre, The Netherlands. Patients were diagnosed between 1986 and 2007.

Table 2.1 summarizes the clinicopathological features of the cases used in this study.

Patient age at first diagnosis ranged from 39-87 years (mean 60) in the OPSCC group with no significant difference between the HPV-positive and the HPV-negative cases. In the papilloma group the age ranged from 1-72 years (mean 43) and in the dysplasia group from 36-82 years (mean 62). The specimens included 162 OPSCC (from 162 patients) and 84 benign and premalignant samples (from 65 patients), i.e., 14 tonsillar dysplasias from 12 patients, 13 of which were adjacent to an invasive carcinoma, 20 tonsillar papillomas (from 20 patients), 23 laryngeal dysplasias (from 19 patients) and 27 laryngeal papillomas (from 14 patients).

A correlation of the HPV16 status with the disease-free survival (DFS) data with a maximum follow-up time up to 180 months and a mean of 36 months revealed that the DFS after 5 years was $55 \%$ for patients with an HPV-negative carcinoma and $74 \%$ for patients with an HPV-positive carcinoma (Hazard ratio $=0.4 ; 95 \%$ Confidence Interval=0.2-0.8), indicating that we used a representative OPSCC patient group.

The OPSCC and dysplasias were histologically classified according to the criteria of the World Health Organization (CJP-K. and HPD). ${ }^{27}$ Eleven out of 14 tonsillar dysplasias were graded as severe and three as moderate. From the laryngeal dysplasias six were graded as mild, eight as moderate and nine cases as severe (see Table 2.1). 
Table 2.1 HPV-status and clinicopathological features of all head and neck lesion studied.

\begin{tabular}{|c|c|c|c|c|c|}
\hline & $\begin{array}{l}\text { OPSCC } \\
(n=162)\end{array}$ & $\begin{array}{l}\text { Tonsillar } \\
\text { dysplasia } \\
(n=14)\end{array}$ & $\begin{array}{l}\text { Tonsillar } \\
\text { papilloma } \\
(\mathrm{n}=20)\end{array}$ & $\begin{array}{l}\text { Laryngeal } \\
\text { dysplasia } \\
(n=23)\end{array}$ & $\begin{array}{c}\text { Laryngeal } \\
\text { papilloma } \\
(\mathrm{n}=27)\end{array}$ \\
\hline $\begin{array}{l}\text { Number of different } \\
\text { patients } \\
\text { Gender }\end{array}$ & 162 & 12 & 20 & 19 & 14 \\
\hline Male & $117(72 \%)$ & $9(75 \%)$ & $12(60 \%)$ & $18(95 \%)$ & $12(86 \%)$ \\
\hline Female & 45 (28\%) & $3(25 \%)$ & $8(40 \%)$ & $1(5 \%)$ & $2(14 \%)$ \\
\hline $\begin{array}{l}\text { Mean age at first } \\
\text { diagnosis (range) }\end{array}$ & $60(39-87)$ & $60(36-79)$ & $42(5-66)$ & $63(43-82)$ & $44(1-72)$ \\
\hline $\begin{array}{l}\text { TNM status } \\
\text { T1 } \\
\text { T2 } \\
\text { T3 } \\
\text { T4 }\end{array}$ & $\begin{array}{l}23(14 \%) \\
54(33 \%) \\
46(29 \%) \\
39(24 \%)\end{array}$ & & & & \\
\hline $\begin{array}{l}\text { N0 } \\
\text { N1 } \\
\text { N2 } \\
\text { N3 } \\
\text { Missing }\end{array}$ & $\begin{array}{c}51(31 \%) \\
29(18 \%) \\
64(39 \%) \\
15(9 \%) \\
3(3 \%)\end{array}$ & & & & \\
\hline $\begin{array}{l}\text { M+ } \\
\text { Histology grade } \\
\text { (all samples) }\end{array}$ & $4(3 \%)$ & & & & \\
\hline $\begin{array}{l}\text { Mild } \\
\text { Moderate } \\
\text { Severe }\end{array}$ & & $\begin{array}{c}0(0 \%) \\
3(21 \%) \\
11(79 \%)\end{array}$ & & $\begin{array}{l}6(26 \%) \\
8(35 \%) \\
9(39 \%)\end{array}$ & \\
\hline $\begin{array}{l}\text { Number of HPV- } \\
\text { positive samples } \\
\text { HPV-PCR } \\
\text { (all samples) }\end{array}$ & $51(31 \%)$ & $10(71 \%)$ & $0(0 \%)$ & $4(17 \%)$ & $26(96 \%)$ \\
\hline $\begin{array}{l}\text { HPV } 6 \\
\text { HPV } 11\end{array}$ & & & & $\begin{array}{l}4^{1} \\
2\end{array}$ & $\begin{array}{r}17 \\
9\end{array}$ \\
\hline $\begin{array}{l}\text { HPV } 16 \\
\text { HPV-FISH } \\
\text { (all samples) }\end{array}$ & 51 & 10 & & & \\
\hline $\begin{array}{l}\text { Integrated } \\
\text { Episomal }\end{array}$ & 51 & $\begin{array}{l}9 \\
1\end{array}$ & & 4 & $\begin{array}{c}1^{2} \\
26\end{array}$ \\
\hline
\end{tabular}

${ }^{1}$ Two out of these 4 HPV6-positive samples were also positive for HPV11; ${ }^{2}$ This sample showed both episomal and integrated HPV6.

\section{P16 ${ }^{\text {INK4A }}$ immunohistochemistry}

Immunostaining of $\mathrm{p} 16^{\mathrm{INK} 4 \mathrm{~A}}$ was performed on $4 \mu \mathrm{m}$-thick formaldehyde fixed, paraffin embedded tissue sections, which were deparrafinized using xylol. As a primary $\mathrm{p} 16^{\mathrm{INK} 4 \mathrm{a}}$ antibody clone E6H4 (Roche, Almere, The Netherlands) was used and detected using Powervision (DAKO A/S, Glostrup, Denmark) and peroxidase-DAB visualisation, as previously described. ${ }^{7}$ 
Three independent observers (JJM, SEG, E-JS) performed evaluations of the immunostained samples and consensus was acquired about the scores.

P16 ${ }^{\text {INK4A }}$ immunostaining patterns were first scored on a semiquantative scale, using the following evaluation criteria: Score 0 indicates that the majority of the cells are negative and that only up to $5 \%$ of the cells show nuclear immunoreactivity with or without cytoplasmic staining; Score 1 indicates that $5-10 \%$ of the cells show a nuclear reactivity with or without cytoplasmic positivity; Score 2 indicates a focal staining pattern with 10-25\% of the cells showing nuclear reactivity with or without cytoplasmic positivity; Score 3 indicates that $>25 \%$ cells show a strong nuclear staining reaction with or without cytoplasmic positivity. ${ }^{14}$

The proportion of positive cells is the primary parameter, with the intensity as a secondary scoring parameter. All cases scored as 2 and 3 showed a strong immunostaining intensity, while few cases scored as 1 stained less intensely positive.

In addition, we scored the $\mathrm{p} 16^{\mathrm{INK} 4 \mathrm{~A}}$ staining patterns according to the "blocktype' immunopositivity approach, defined as $\mathrm{p} 16^{\text {INK4A }}$ only being block positive if continuous $(>70 \%)$ strong nuclear with or without cytoplasmic staining is present (in all head and neck lesions) and staining is observed in the basal cell layer with extension upwards (in the benign and premalignant lesions). ${ }^{23}$ Controls included sections of uterine cervical IN grade 2 and 3 (positive controls) and sections from the same cases on which the $\mathrm{p} 16^{\mathrm{INK} 4 \mathrm{~A}}$ antibody was substituted by a monoclonal mouse IgG2a antibody to Aspergillus Niger or by buffer without a primary antibody (negative controls).

\section{DNA isolation and HPV typing by PCR}

For DNA isolation, tissues were processed with the QIAamp Tissue Kit (Qiagen, Hilden, Germany) according to the manufacturers' instructions. Total cellular DNA was eluted with $250 \mu \mathrm{l}$ of the AE-buffer (Qiagen) and $5 \mu \mathrm{l}$ were used in each of the PCR analyses.

To test the quantity and quality of the DNA samples and to demonstrate that the samples were free from inhibitory substances, PCR was performed for the B-Globin gene, resulting in a $268 \mathrm{bp} \mathrm{PCO} / \mathrm{GH} 20$ PCR product. ${ }^{28}$ As negative controls water and as positive controls human placental DNA were included in each PCR run.

HPV sequences were detected by highly sensitive group-specific nested PCR protocols with degenerate primers A5/A10 and A6/A8 for HPV as previously described. ${ }^{29}$ PCR products $(5 \mu \mathrm{l})$ were separated on $2 \%$ agarose gels and visualized by ethidium bromide staining. For HPV typing internal biotinylated A6/A8-PCR products $(270 \mathrm{bp})$ were hybridized with 37 type-specific digoxigenin-labeled oligonucleotide probes in an enzyme-immunoassay as described earlier. ${ }^{30,31}$ 


\section{Detection of HPV6-, 11-, 16- and 18 by FISH}

FISH was performed on 4- $\mu \mathrm{m}$ thick formaldehyde fixed and paraffin-embedded tissue sections tissue as described previously. ${ }^{32-34}$ Briefly, sections were deparaffinized, pre-treated with $85 \%$ formic acid/0.3\% $\mathrm{H}_{2} \mathrm{O}_{2}, 1 \mathrm{M} \mathrm{NaSCN}$ and $4 \mathrm{mg} / \mathrm{ml}$ pepsin, post-fixed in $1 \%$ formaldehyde in PBS, dehydrated in an ethanol series and hybridized with digoxigenin-labeled HPV6-, 11-, 16- and 18specific probes (PanPath, Budel, The Netherlands), respectively, depending on PCR results, according to the manufacturer's instructions. After hybridization the preparations were washed stringently in $50 \%$ formamide, $2 \times S S C$ at $42^{\circ} \mathrm{C}$ (two times $5 \mathrm{~min}$ ). The probes were detected by subsequent application of mouse anti-digoxigenin (Sigma, St. Louis, MO), peroxidase-conjugated rabbit anti-mouse and peroxidase-conjugated swine anti-rabbit (both DAKO), and visualized by a peroxidase based amplification reaction using rhodaminelabeled tyramide. ${ }^{35,36}$ Preparations were mounted in Vectashield (Vector Laboratories, Burlingame, CA) containing 4,6-diamidino-2-phenyl indole (DAPI; Sigma: $0.2 \mathrm{~g} / \mathrm{ml}$ ). Microscope images were recorded with the Metasystems Image Pro System (black and white CCD camera; Sandhausen, Germany) mounted on top of a Leica DM-RE fluorescence microscope equipped with DAPI and rhodamine filters.

Evaluation of nuclear hybridization signals was performed by two investigators (JJM, E-JMS) according to the criteria described by Mooren et al., ${ }^{37}$ i.e., nuclear punctate signals were considered to indicate integrated HPV-DNA and diffuse signals to indicate episomal HPV-DNA. Controls included hybridizations on HPV6-, -11-, -16- and 18-positive formaldehyde-fixed, paraffin-embedded tissues of known human uterine cervical and head and neck (pre)malignancies. Negative controls consisted of HPV-negative tissue sections as determined by PCR and hybridizations omitting the viral probe.

\section{Statistical analysis}

HPV-status and p16 INK4A immunostaining were correlated using crosstabulations and the two-tailed Fisher exact test and/or Chi-square test. We regarded a p-value $\leq 0.05$ as level of significance. DFS in the OPSCC group was calculated from the date of diagnosis until the date of recurrence (local, regional or distant, whichever occurred first). Patients without recurrence were censored at the date of the last follow-up or the date of death. The statistical significance of differences between survival times was determined by the log rank test in univariate analysis. All statistical analyses were performed by PASW Statistics version 18.0. 


\section{Results}

\section{HPV-status of the head and neck lesions examined in this study}

The HPV-status of the OPSCC, the premalignant and the benign head and neck lesions is presented in Table 2.1. Only when the presence of HPV was detected by both PCR and FISH the sample was judged to be HPV-positive.

Of the 162 OPSCC 51 (31\%) were found to be positive for HPV16. All 51 cases showed integrated HPV16, as concluded from the FISH-analyses. No other HPV-subtypes were detected in these lesions.

Forty of the 84 benign and premalignant lesions (48\%) were HPV-positive: $10(71 \%)$ of the 14 tonsillar dysplasias harbored HPV16; $4(16 \%)$ of the 23 laryngeal dysplasias harbored HPV6, of which two also contained HPV11; of the 27 laryngeal papillomas $17(63 \%)$ were positive for HPV6, and nine (33\%) for HPV11. The frequency of HPV-infections in these lesions is in accordance with previous studies. ${ }^{38-41}$ Remarkably, all 20 samples of tonsillar papillomas were HPV-negative.

In all HPV16-positive tonsillar dysplasias the virus was integrated (Figure 2.2B), whereas in one sample additionally an episomal FISH pattern was detected in the cell nuclei surrounding tonsillar crypts (data not shown). In all, except one sample, of the HPV6- or 11-positive laryngeal lesions the virus was episomal (Figure 2.2H).

In the Supplementary Table S2.1 the HPV-positivity per patient is presented, for comparison, showing only a slightly difference in the frequency of HPV-positivity in the tonsillar dysplasias (83\% per patient versus $71 \%$ per sample) and the laryngeal papillomas (93\% versus $96 \%$ ).

\section{Strong correlation between $\mathrm{p} 16^{\mathrm{INK} 4 \mathrm{~A}}$ overexpression and HR-HPV16 in OPSCC and tonsillar dysplasias}

The $\mathrm{p} 16^{\mathrm{INK} 4 \mathrm{~A}}$ scores in the HPV-positive and -negative lesions, using the two different scoring methods, are shown per subgroup in Figure 2.1A and 2.1B. The analyses per patient are presented in Supplementary Figures S2.1A and S2.1B.

The presence of HR-HPV16 in the OPSCC was significantly associated $(p<0.0001)$ with a strong $p 16^{\mathrm{INK} 4 \mathrm{~A}}$ immunostaining reaction (staining score 3 ) and with a block positive p $16^{\mathrm{INK} 4 \mathrm{~A}}$ immunostaining: 50 out of 51 HPV16-positive OPSCC showed strong nuclear and cytoplasmic p $16^{\text {INK } 4 \mathrm{~A}}$ immunopositivity in more than $70 \%$ of the tumour cells, whereas only five out of the 111 HPV16negative tumours were $\mathrm{p} 16^{\mathrm{INK} 4 \mathrm{~A}}$ positive. 

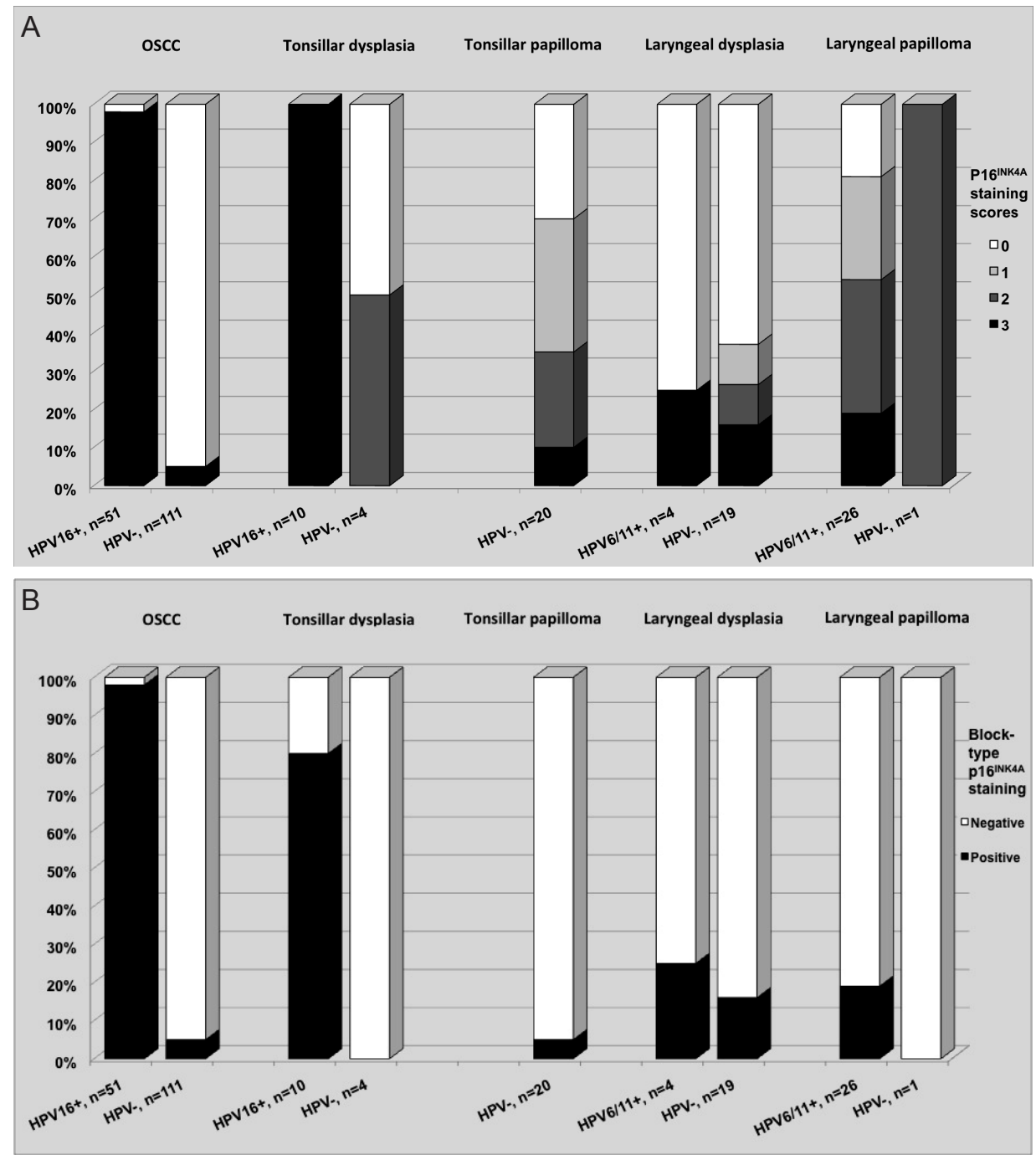

Figure 2.1 A) $\mathrm{P} 16^{\mathrm{INK} 4 \mathrm{~A}}$ immunostaining scores in all (pre)malignant and benign head and neck lesions. Scoring criteria: Score 0 negative; Score 1: $5-10 \%$ of the cells show a nuclear reactivity with or without cytoplasmic positivity; Score 2: focal staining pattern with $10-25 \%$ of the cells showing nuclear reactivity with or without cytoplasmic positivity; Score 3: $>25 \%$ cells show a strong nuclear staining reaction with or without cytoplasmic positivity. ${ }^{14}$ B) Immunostaining results for $\mathrm{p} 16^{\text {INK4A }}$ in all (pre)malignant and benign head and neck lesions based on the block-type scoring approach, defined as $\mathrm{p} 16^{\mathrm{INK} 4 \mathrm{~A}}$ only being interpreted as positive if continuous (>70\%) strong nuclear with or without cytoplasmic staining is present (in all head and neck lesions) and is observed in the basal cell layer with extension upwards (in the benign and premalignant lesions). ${ }^{23}$ 
Also all 10 HPV16-positive tonsillar dysplasia samples showed strong (score 3) p16 ${ }^{\text {INK4A }}$ expression (Figure 2.2A). In eight of these an equally strong staining intensity in the nuclei and cytoplasm could be observed in more than $70 \%$ of the dysplastic cells and these were scored as block positive. The remaining two HPV16-positive samples showed a strong (score 3) p16 $6^{\mathrm{INK} 4 \mathrm{~A}}$ immunostaining reaction in $40-50 \%$ of the lesion, being block negative.

Of the $4 \mathrm{HPV}$-negative tonsillar dysplasia samples two showed an intermediate p16 ${ }^{\text {INK4A }}$ staining pattern (score 2) and two samples from one patient were negative (score 0 ), implying that these were all block negative.

\section{Highly variable $\mathrm{p} 16^{\mathrm{INK} 4 \mathrm{~A}}$ immunostaining patterns in the tonsillar papillomas and laryngeal lesions}

In the 20 HPV-negative tonsillar papillomas the $\mathrm{p} 16^{\mathrm{INK} 4 \mathrm{~A}}$ immunostaining patterns were highly variable and ranged from a negative score to a strong staining intensity in $30-80 \%$ of the cells (Figure $2.2 \mathrm{D}-\mathrm{F}$ and Figure $2.1 \mathrm{~A}$ ). Only one sample was $\mathrm{p} 16^{\mathrm{INK} 4 \mathrm{~A}}$ block positive (Figure $\left.2.1 \mathrm{~B}\right)$. In $12(86 \%)$ out of the $14 \mathrm{p} 16^{\text {INK4A }}$ positive tonsillar papillomas the immunostaining intensity of the nucleus was stronger than that of the cytoplasm.

Of the 23 laryngeal dysplasias four samples (two from one patient) showed a strong, four a low to intermediate and 15 (two from one patient) no $\mathrm{p} 16^{\text {INK4A }}$ expression (Figure 2.1A). Three of the four HPV6-positive lesions, of which two samples from the same patient harbored HPV11-DNA, were $\mathrm{p} 16^{\text {INK4A }}$ negative. The remaining HPV6-positive dysplasia sample showed a strong $\mathrm{p} 16^{\text {INK4A }}$ immunostaining (score 3 ) and was also block positive (Figures 2.2C and 2.2G and Figures 2.1A and 2.1B). There was no association between $\mathrm{p} 16^{\text {INK4A }}$ score and the degree of dysplasia. Although all five mild dysplasias were also $\mathrm{p} 16^{\mathrm{INK} 4 \mathrm{~A}}$ negative, the moderate and severe dysplasias showed negative to strong $\mathrm{p} 16^{\mathrm{INK} 4 \mathrm{~A}}$ staining patterns.

$\mathrm{P} 16^{\text {INK4A }}$ staining patterns in the HPV6 and-11-positive laryngeal papillomas varied from negative to strongly positive. Five out of the $26 \mathrm{HPV}$-positive laryngeal papillomas were $\mathrm{p} 16^{\text {INK4A }}$ block positive, three of these being from the same patient. Similar to most tonsillar papillomas, all of the $\mathrm{p} 16^{\text {INK4A }}$ positive laryngeal lesions showed a stronger nuclear than cytoplasmic staining intensity.

In the Supplementary Figures $2.1 \mathrm{~A}$ and $2.1 \mathrm{~B}$ the $\mathrm{p} 16^{\mathrm{INK} 4 \mathrm{~A}}$-positivity per patient is presented, showing only minor differences in the frequencies of $\mathrm{p} 16^{\mathrm{INK} 4 \mathrm{~A}}$-immunostaining scores, compared to those presented in Figures $2.1 \mathrm{~A}$ and 2.1B (analyses per sample). 

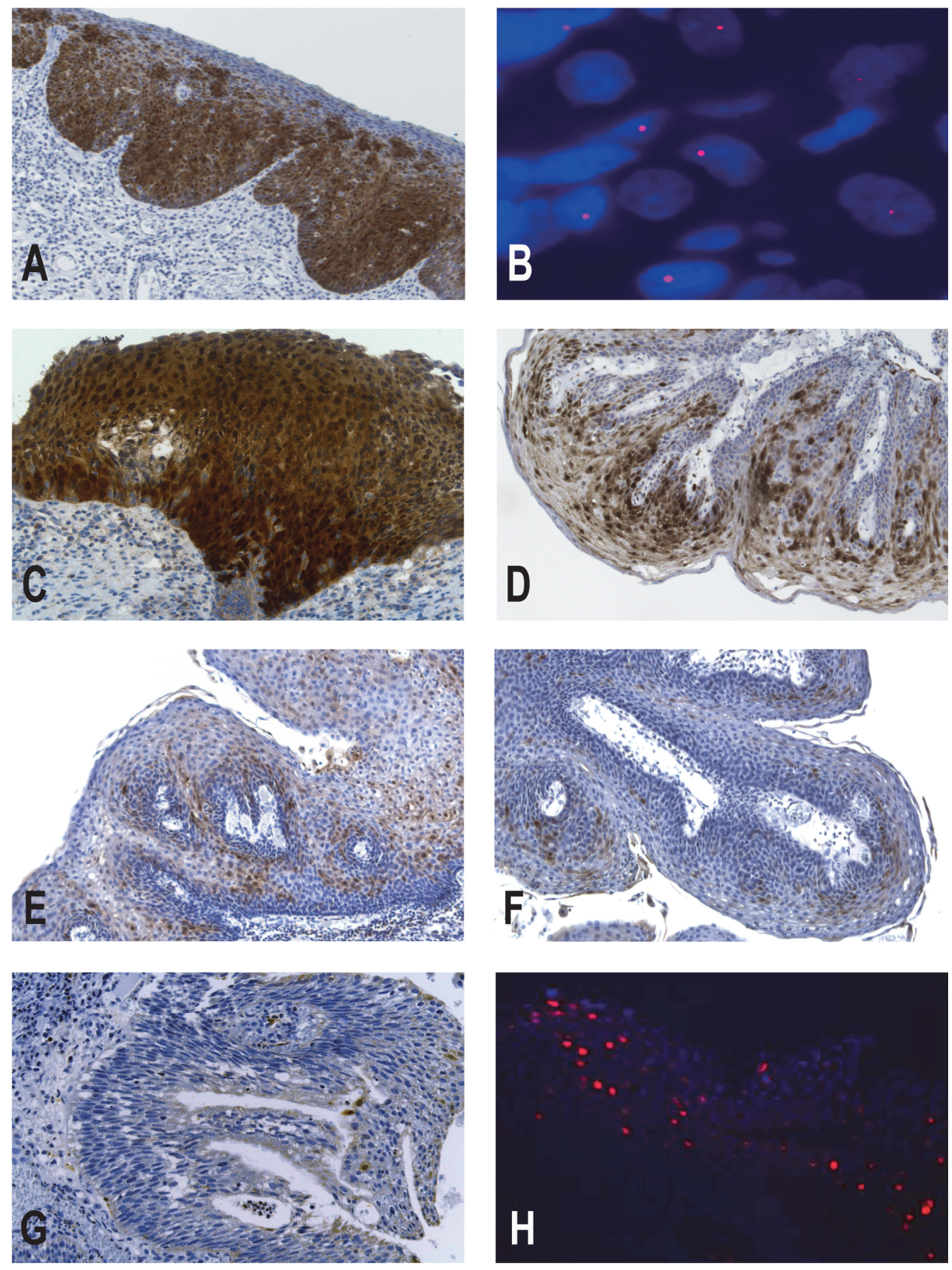
Figure 2.2 Representative examples of $\mathrm{p} 16^{\mathrm{INK} 4 \mathrm{~A}}$ immunohistochemistry (A, C-G) and HPVspecific FISH analysis (B, H) in head and neck lesions. (A) Strong nuclear and cytoplasmic $\mathrm{p} 16^{\mathrm{INK} 4 \mathrm{~A}}$ immunostaing (score 3 ) and also block-positive p16 ${ }^{\text {INK4A }}$ staining pattern in a tonsillar dysplasia; (B) Punctate signal (red) per nucleus (blue DAPI) indicating integrated HPV16 in a tonsillar dysplasia; (C) Strong nuclear and cytoplasmic $\mathrm{p} 16^{\mathrm{INKAA}}$ immunostaining (score 3 ) and also block-positive $\mathrm{p} 16^{\mathrm{INK} 4 \mathrm{~A}}$ staining pattern in a laryngeal dysplasia sample; (D) Tonsillar papilloma sample showing strong nuclear and weaker cytoplasmic $\mathrm{p} 16^{\mathrm{INK} 4 \mathrm{~A}}$ immunostaining (score 3 ), but scored as being block-negative. (E, F) Tonsillar papilloma samples showing a focal staining pattern with $10-25 \%$ of the cells showing nuclear and cytoplasmic positivity (score 2; $(E)$, and showing $5-10 \%$ of the cells with a nuclear and cytoplasmic positivity (score 1 ; (F, G) Laryngeal dysplasia sample showing $0-5 \%$ of the cells showing nuclear and cytoplasmic p16 ${ }^{\mathrm{INK} 4 \mathrm{~A}}$ immunopositivity (score 0); (H) Diffusely (red) stained nuclei (blue DAPI) indicating episomal presence of HPV6 in a laryngeal papilloma.

\section{Discussion}

Overexpression of $\mathrm{p} 16^{\text {INK4A }}$ has been put forward as a specific surrogate biomarker for the presence of HR-HPV, in particular in (pre)malignancies of the uterine cervix, as well as those in the head and neck region. ${ }^{6,7,13,14}$ However, there still exists controversy on the reliability of $\mathrm{p} 16^{\mathrm{INK} 4 \mathrm{~A}}$ expression as indicator for the presence of HPV, particularly in the latter group. In our study, we analysed the relationship between HR- and LR-HPV-status and $\mathrm{p} 16^{\text {INK4A }}$ immunostaining patterns in 246 samples of benign, premalignant and malignant head and neck lesions. A strong (score 3 ) and block positive nuclear and cytoplasmic $\mathrm{p} 16^{\mathrm{INK} 4 \mathrm{~A}}$ staining pattern was predominantly found to correlate with HPV16-containing OPSCC and tonsillar dysplasias. In contrast, the tonsillar and laryngeal papillomas, as well as the laryngeal dysplasias showed a highly variable $\mathrm{p} 16^{\mathrm{INK} 4 \mathrm{~A}}$ staining pattern, independent of the HPV-status. By using the block-type scoring approach, however, most of these lesions were interpreted as being $\mathrm{p} 16^{\mathrm{INK} 4 \mathrm{~A}}$ block negative.

It is now well established that HPV-associated HNSCC represent a separate entity, which is clinically and molecularly distinct from its tobacco- and/or alcohol-induced counterpart. ${ }^{2,7,37}$ The upregulation of $\mathrm{p} 16^{\text {INK4A }}$ results from inactivation of $\mathrm{pRb}$ by the HPV-E7 oncoprotein, or alternatively through E7-mediated epigenetic induction of KDM6B, subsequently leading to activation of the $\mathrm{p} 16^{\mathrm{INK} 4 \mathrm{~A}}$ gene..$^{6,16}$

Although several studies have reported a high interobserver conformity in the evaluation of $\mathrm{p} 16^{\mathrm{INK} 4 \mathrm{~A}}$ immunostaining patterns, ${ }^{4,14,18,19,42}$ others have indicated limitations in this procedure. The immunohistochemical $\mathrm{p} 16^{\mathrm{INK} 4 \mathrm{~A}}$ staining procedure is subject to variations in the protocol and to difficulties in the interpretation of the staining patterns as a result of different scoring criteria. ${ }^{17}$ There is an emerging consensus that only samples showing strong nuclear and cytoplasmic $\mathrm{p} 16^{\mathrm{INK} 4 \mathrm{~A}}$ immunostaining, observed in more than $25 \%$ of tumour 


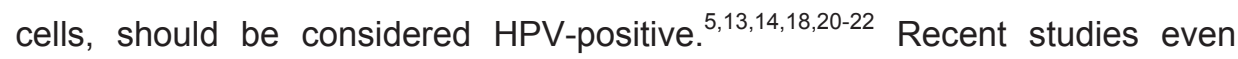
suggest to use $70 \%$ immunopositivity of the carcinoma tissue as a cut-off point. ${ }^{4,11,12}$ In our study, we indeed observed the strong and block positive p16 ${ }^{\text {INK4A }}$ immunostaining in all except one HPV16-positive OPSCC. Despite the fact that a small fraction of the HPV-negative OPSCC did show p16 $6^{\text {INK4A }}$ positivity, the correlation of this surrogate marker with HPV16-presence is highly significant.

Also in all HPV16-positive tonsillar dysplasias of the present study a strong, and in most cases block positive, $\mathrm{p} 16^{\text {INK4A }}$ immunostaining pattern could be detected, which is in accordance with the results in cervical dysplasias. ${ }^{14,19}$ Similar to OPSCC, also in these lesions we identified $\mathrm{p} 16^{\mathrm{INK} 4 \mathrm{~A}}$ positive staining in two HPV-negative samples, albeit with an intermediate score and being block negative.

The use of $\mathrm{p} 16^{\mathrm{INK} 4 \mathrm{~A}}$ immunostaining as surrogate marker for HPV-presence in laryngeal dysplasias and head and neck papillomas, however, is unreliable. In the HPV6/11-positive laryngeal dysplasia samples the majority of cases was p16 ${ }^{\text {INK4A }}$ negative, while $1 / 3$ of the HPV-negative samples did show $\mathrm{p} 16^{\text {INK4A }}$ positivity. LR-HPV-integration seldomly occurs and the only laryngeal papilloma sample harbouring nuclear punctate HPV6-FISH signals only showed weak p16 ${ }^{\text {INK4A }}$ immunostaining. In a recent study on juvenile onset laryngeal papillomatosis progressing to carcinoma in one patient, the papilloma with episomal and the carcinoma with integrated HPV6 were all $p 16^{\text {INK4A }}$ negative. ${ }^{43}$ All our tonsillar papilloma samples were HPV-negative, whereas $70 \%$ of the samples showed variable $\mathrm{p} 16^{\mathrm{INK} 4 \mathrm{~A}}$ positivity, indicating that $\mathrm{p} 16^{\text {INK4A }}$ immunostaining appears of no use for predicting HPV-presence in these lesions. This is in accordance with a previous study on tumour-free palatine tonsils, all proven to be negative for HPV, but showing $\mathrm{p} 16^{\mathrm{INK} 4 \mathrm{~A}}$ overexpression in a quarter of these normal cases. ${ }^{25}$ By using the block-type scoring system, however, most tonsillar and laryngeal papillomas and laryngeal dysplasias were interpreted as being $\mathrm{p} 16^{\mathrm{INK} 4 \mathrm{~A}}$ block negative. This fits with the fact that these head and neck lesions are usually HPV-negative or contain LR-HPV types. Block-positivity is used to identify HR-HPV-containing precancerous anogenital lesions, which is in accordance with the block-positivity observed in our study in OPSCC and tonsillar dysplasias, being associated with HR-HPV. ${ }^{23}$ Also at a subcellular level variability in $\mathrm{p} 16^{\text {INK4A }}$ immunostaining patterns could be observed: in the HPV16-positive OPSCC and tonsillar dysplasias we predominantly found an equally strong $\mathrm{p} 16^{\mathrm{INK} 4 \mathrm{~A}}$ staining intensity in nuclei and cytoplasm, whereas in the other head and neck lesions the nuclear intensity was generally stronger than that of the cytoplasm.

The fact that studies on oral papillomas showed an HPV-positivity in 13-60\%, predominantly HPV6 or $-11,{ }^{44-46}$ makes the absence of HPV in the tonsillar 
papillomas in our series remarkable. The lack of HPV in these samples might be explained by elimination of the virus by the immune system with persistence of the lesions, or by the fact that other viruses, yet to be discovered, play an etiological role in the development of the tonsillar papillomas. Also the mechanisms underlying the predilection of different HPV-types for different anatomical head and neck lesions remain to be further explored.

The highly variable $\mathrm{p} 16^{\mathrm{INK} 4 \mathrm{~A}}$ immunostaining patterns in the benign and premalignant head and neck lesions may be explained by several other factors. It is well described in the literature that in uterine cervical lesions LR-HPV6 results in a less intense $\mathrm{p} 16^{\mathrm{INK} 4 \mathrm{~A}}$ immunostaining pattern as compared to HPV16, which is caused by the fact that the affinity of the HPV6 E7 protein for cellular pRb is 10 -fold lower than that of HPV16 E7. ${ }^{19,47,48}$ Therefore, it is surprising that our HPV6/11-containing benign and premalignant head and neck samples were often strongly positive, or completely negative for $\mathrm{p} 16^{\mathrm{INK} 4 \mathrm{~A}}$.

Since a subgroup of HPV-negative lesions also shows overexpression of $\mathrm{p} 16^{\mathrm{INK} 4 \mathrm{~A}}$, several factors have been proposed to explain this observation, which remain to be studied. These include infection with other viruses (i.e., cytomegalovirus and adenovirus), which functionally inactivate $\mathrm{pRb}$ in a similar fashion as the HPV-oncogene E7, ${ }^{49,50}$ physiological stress, oncogene-driven senescence by functional overactivation of (proto)oncogenes including Ras, Raf, MEK and E2F, or replicative senescence due to DNA-damage or oxidative stress. ${ }^{51-54}$

In summary, our results indicate that a strong nuclear and cytoplasmic $\mathrm{p} 16^{\text {INK4A }}$ immunostaining pattern can accurately predict the presence of HR-HPV16 in OPSCC and tonsillar dysplasias. Our data underscore the proposed cut-off level of $70 \% \mathrm{p} 16^{\text {INK4A }}$ positive cells, corresponding to block positive $\mathrm{p} 16^{\text {INK4A }}$ immunopositivity, in these lesions as indicator for HR-HPV16-presence. In the other premalignant and benign head and neck lesions, however, caution is recommended when using this surrogate marker for HPV-infection. 

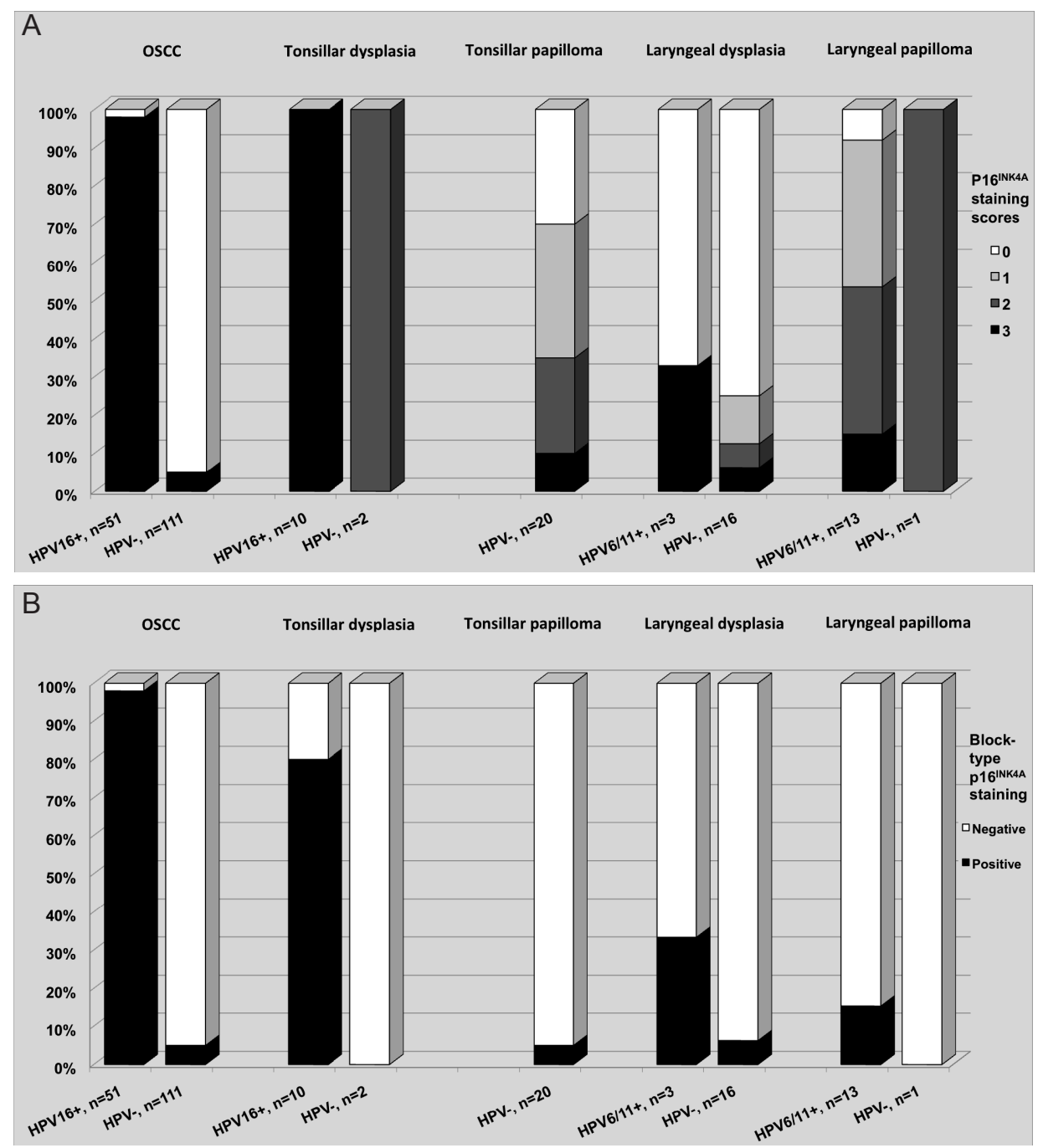

Figure S2.1 A) P16 ${ }^{\mathrm{INK} 4 \mathrm{~A}}$ immunostaining scores in patients with a (pre)malignant and benign head and neck lesion. Scoring criteria: Score 0 negative; Score 1: $5-10 \%$ of the cells show a nuclear reactivity with or without cytoplasmic positivity; Score 2: focal staining pattern with $10-25 \%$ of the cells showing nuclear reactivity with or without cytoplasmic positivity; Score 3: $>25 \%$ cells show a strong nuclear staining reaction with or without cytoplasmic positivity. ${ }^{14}$ B) Immunostaining results for $\mathrm{p} 16^{\text {INK4A }}$ in patients with a (pre)malignant and benign head and neck lesion based on the blocktype scoring approach, defined as $p 16^{\text {INK4A }}$ only being interpreted as positive if continuous $(>70 \%)$ strong nuclear with or without cytoplasmic staining is present (in all head and neck lesions) and is observed in the basal cell layer with extension upwards (in the benign and premalignant lesions). ${ }^{23}$ 
Table S2.1 HPV-status in patients with a head and neck lesion.

\begin{tabular}{|c|c|c|c|c|c|}
\hline & $\begin{array}{l}\text { OPSCC } \\
(n=162)\end{array}$ & $\begin{array}{c}\text { Tonsillar } \\
\text { dysplasia } \\
(n=12)\end{array}$ & $\begin{array}{c}\text { Tonsillar } \\
\text { papilloma } \\
(n=20)\end{array}$ & $\begin{array}{c}\text { Laryngeal } \\
\text { dysplasia } \\
(\mathrm{n}=19)\end{array}$ & $\begin{array}{c}\text { Laryngeal } \\
\text { papilloma } \\
(\mathrm{n}=14)\end{array}$ \\
\hline $\begin{array}{l}\text { Number of } \\
\text { patients with a } \\
\text { HPV-positive } \\
\text { lesion }\end{array}$ & $51(31 \%)$ & $10(83 \%)$ & $0(0 \%)$ & $3(16 \%)$ & $13(93 \%)$ \\
\hline $\begin{array}{l}\text { HPV-PCR } \\
\text { (all patients) }\end{array}$ & & & & & \\
\hline HPV 6 & & & & $3^{1}$ & 9 \\
\hline HPV 11 & & & & 1 & 4 \\
\hline HPV 16 & 51 & 10 & & & \\
\hline $\begin{array}{l}\text { HPV-FISH } \\
\text { (all patients) }\end{array}$ & & & & & \\
\hline Integrated & 51 & 9 & & & $1^{2}$ \\
\hline Episomal & & 1 & & 3 & 12 \\
\hline
\end{tabular}

${ }^{1}$ One out of these 3 HPV6-positive samples was also positive for HPV11; ${ }^{2}$ This sample showed both episomal and integrated HPV6 


\section{References}

1. Shaw $R$, Robinson $M$. The increasing clinical relevance of human papillomavirus type 16 (HPV-16) infection in oropharyngeal cancer. $\mathrm{Br} J$ Oral Maxillofac Surg 2011;49:423-9.

2. Olthof NC, Straetmans JMJAA, Snoeck R, Ramaekers FCS, Kremer B, Speel EJM. Next-generation treatment strategies for human papillomavirus-related head and neck squamous cell carcinoma: where do we go? Rev Med Virol 2012;22: 88-105.

3. Goon P, Sonnex C, Jani P, Stanley M, Sudhoff H. Recurrent respiratory papillomatosis: an overview of current thinking and treatment. European Archives of Oto-Rhino-Laryngology 2007;265:147-51.

4. Thavaraj S, Stokes A, Guerra E, Bible J, Halligan E, Long A, Okpokam A, Sloan P, Odell E, Robinson M. Evaluation of human papillomavirus testing for squamous cell carcinoma of the tonsil in clinical practice. Journal of Clinical Pathology 2011;64: 308-12.

5. El-Naggar AK, Westra WH. p16 expression as a surrogate marker for HPV-related oropharyngeal carcinoma: A guide for interpretative relevance and consistency. Head Neck 2011;34:459-61.

6. Klussmann JP, Gültekin E, Weissenborn SJ, Wieland U, Dries V, Dienes HP, Eckel $\mathrm{HE}$, Pfister HJ, Fuchs PG. Expression of p16 protein identifies a distinct entity of tonsillar carcinomas associated with human papillomavirus. Am J Pathol 2003;162: 747-53.

7. Hafkamp HC, Mooren JJ, Claessen SM, Klingenberg B, Voogd AC, Bot FJ, Klussmann JP, Hopman AH, Manni JJ, Kremer B, Ramaekers FC, Speel EJ. P21 Cip1/WAF1 expression is strongly associated with HPV-positive tonsillar carcinoma and a favorable prognosis. Mod Pathol 2009;22:686-98.

8. Li W, Thompson CH, Cossart YE, O'Brien CJ, McNeil EB, Scolyer RA, Rose BR. The expression of key cell cycle markers and presence of human papillomavirus in squamous cell carcinoma of the tonsil. Head Neck 2004;26:1-9.

9. Wiest T, Schwarz E, Enders C, Flechtenmacher C, Bosch FX. Involvement of intact HPV16 E6/E7 gene expression in head and neck cancers with unaltered p53 status and perturbed pRb cell cycle control. Oncogene 2002;21:1510-7.

10. Hafkamp HC, Manni JJ, Haesevoets A, Voogd AC, Schepers M, Bot FJ, Hopman AHN, Ramaekers FCS, Speel E-JM. Marked differences in survival rate between smokers and nonsmokers with HPV 16-associated tonsillar carcinomas. Int $J$ Cancer 2008;122:2656-64.

11. Rietbergen MM, Leemans CR, Bloemena E, Heideman DAM, Braakhuis BJM, Hesselink AT, Witte BI, de Jong RJB, Meijer CJLM, Snijders PJF, Brakenhoff RH. Increasing prevalence rates of HPV attributable oropharyngeal squamous cell carcinomas in the Netherlands as assessed by a validated test algorithm. Int $\mathrm{J}$ Cancer 2013;132:1565-71.

12. Jordan RC, Lingen MW, Perez-Ordonez B, He X, Pickard R, Koluder M, Jiang B, Wakely P, Xiao W, Gillison ML. Validation of methods for oropharyngeal cancer HPV status determination in US cooperative group trials. Am J Surg Pathol 2012; 36:945-54.

13. Fregonesi PAG, Teresa DB, Duarte RA, Neto CB, de Oliveira MRB, Soares CP. p16(INK4A) immunohistochemical overexpression in premalignant and malignant oral lesions infected with human papillomavirus. J Histochem Cytochem 2003;51: 1291-7. 
14. Klaes R, Friedrich T, Spitkovsky D, Ridder R, Rudy W, Petry U, DallenbachHellweg G, Schmidt D, Knebel Doeberitz von M. Overexpression of p16(INK4A) as a specific marker for dysplastic and neoplastic epithelial cells of the cervix uteri. Int J Cancer 2001;92:276-84.

15. Klaes R, Benner A, Friedrich $T$, Ridder R, Herrington S, Jenkins D, Kurman RJ, Schmidt D, Stoler M, Knebel Doeberitz von M. p16INK4a immunohistochemistry improves interobserver agreement in the diagnosis of cervical intraepithelial neoplasia. Am J Surg Pathol 2002;26:1389-99.

16. McLaughlin-Drubin ME, Crum $\mathrm{CP}$, Münger $\mathrm{K}$. Human papillomavirus E7 oncoprotein induces KDM6A and KDM6B histone demethylase expression and causes epigenetic reprogramming. Proc Natl Acad Sci USA 2011;108:2130-5.

17. van Bogaert L-J. P16(INK4a) immunocytochemistry/immunohistochemistry: need for scoring uniformization to be clinically useful in gynecological pathology. Ann Diagn Pathol 2012;16:422-6.

18. Yildiz IZ, Usubutun A, Firat P, Ayhan A, Kucukali T. Efficiency of immunohistochemical p16 expression and HPV typing in cervical squamous intraepithelial lesion grading and review of the p16 literature. Pathol Res Pract 2007;203:445-9.

19. Sano T, Oyama T, Kashiwabara K, Fukuda T, Nakajima T. Expression status of p16 protein is associated with human papillomavirus oncogenic potential in cervical and genital lesions. Am J Pathol 1998;153:1741-8.

20. Lambert APF, Anschau F, Schmitt VM. p16INK4A expression in cervical premalignant and malignant lesions. Exp Mol Pathol 2006;80:192-6.

21. Murphy N, Ring M, Killalea AG, Uhlmann V, ODonovan M, Mulcahy F, Turner M, McGuinness E, Griffin M, Martin C, Sheils O, OLeary JJ. p16INK4A as a marker for cervical dyskaryosis: CIN and CGIN in cervical biopsies and ThinPrep smears. Journal of Clinical Pathology 2003;56:56-63.

22. Missaoui N, Trabelsi A, Hmissa S, Fontanière B, Yacoubi MT, Mokni M, Korbi S, Frappart L. p16INK4A overexpression in precancerous and cancerous lesions of the uterine cervix in Tunisian women. Pathology - Research and Practice 2010; 206:550-5.

23. Darragh TM, Colgan TJ, Thomas Cox J, Heller DS, Henry MR, Luff RD, McCalmont T, Nayar R, Palefsky JM, Stoler MH, Wilkinson EJ, Zaino RJ, et al. The Lower Anogenital Squamous Terminology Standardization project for HPVassociated lesions: background and consensus recommendations from the College of American Pathologists and the American Society for Colposcopy and Cervical Pathology. Int J Gynecol Pathol 2013;32:76-115.

24. Holzinger D, Schmitt M, Dyckhoff G, Benner A, Pawlita M, Bosch FX. Viral RNA patterns and high viral load reliably define oropharynx carcinomas with active HPV16 involvement. Cancer Res 2012;72:4993-5003.

25. Klingenberg B, Hafkamp HC, Haesevoets A, Manni JJ, Slootweg PJ, Weissenborn SJ, Klussmann JP, Speel E-JM. p16 INK4A overexpression is frequently detected in tumour-free tonsil tissue without association with HPV. Histopathology 2010;56:957-67.

26. Harris SL, Thorne LB, Seaman WT, Hayes DN, Couch ME, Kimple RJ. Association of p16(INK4a) overexpression with improved outcomes in young patients with squamous cell cancers of the oral tongue. Head Neck 2011;33:1622-7.

27. Shanmugaratnam S. Histologic typing of tumors of the upper respiratory tract and ear. Geneva (Switserland): World Health Organization, 1991. 
28. Bauer HM, Ting Y, Greer CE, Chambers JC, Tashiro CJ, Chimera J, Reingold A, Manos MM. Genital human papillomavirus infection in female university students as determined by a PCR-based method. JAMA 1991;265:472-7.

29. Wieland U, Jurk S, Weissenborn S, Krieg T, Pfister H, Ritzkowsky A. Erythroplasia of queyrat: coinfection with cutaneous carcinogenic human papillomavirus type 8 and genital papillomaviruses in a carcinoma in situ. $J$ Invest Dermatol 2000;115: 396-401.

30. Jacobs MV, Snijders PJ, van den Brule AJ, Helmerhorst TJ, Meijer CJ, Walboomers JM. A general primer GP5+/GP6(+)-mediated PCR-enzyme immunoassay method for rapid detection of 14 high-risk and 6 low-risk human papillomavirus genotypes in cervical scrapings. J Clin Microbiol 1997;35:791-5.

31. van den Brule AJ, Pol R, Fransen-Daalmeijer N, Schouls LM, Meijer CJ, Snijders PJ. GP5+/6+ PCR followed by reverse line blot analysis enables rapid and highthroughput identification of human papillomavirus genotypes. J Clin Microbiol 2002; 40:779-87.

32. Hafkamp HC, Speel EJM, Haesevoets A, Bot FJ, Dinjens WNM, Ramaekers FCS, Hopman AHN, Manni JJ. A subset of head and neck squamous cell carcinomas exhibits integration of HPV 16/18 DNA and overexpression of p16INK4A and p53 in the absence of mutations in p53 exons 5-8. Int J Cancer 2003;107:394-400.

33. Hopman AH, Kamps MA, Speel EJ, Schapers RF, Sauter G, Ramaekers FC. Identification of chromosome 9 alterations and p53 accumulation in isolated carcinoma in situ of the urinary bladder versus carcinoma in situ associated with carcinoma. Am J Pathol 2002;161:1119-25.

34. Hopman AHN, Smedts F, Dignef W, Ummelen M, Sonke G, Mravunac M, Vooijs GP, Speel E-JM, Ramaekers FCS. Transition of high-grade cervical intraepithelial neoplasia to micro-invasive carcinoma is characterized by integration of HPV 16/18 and numerical chromosome abnormalities. J Pathol 2004;202:23-33.

35. Speel EJ, Ramaekers FC, Hopman AH. Sensitive multicolor fluorescence in situ hybridization using catalyzed reporter deposition (CARD) amplification. J Histochem Cytochem 1997;45:1439-46.

36. Hopman AH, Ramaekers FC, Speel EJ. Rapid synthesis of biotin-, digoxigenin-, trinitrophenyl-, and fluorochrome-labeled tyramides and their application for In situ hybridization using CARD amplification. J Histochem Cytochem 1998;46:771-7.

37. Mooren JJ, Kremer B, Claessen SMH, Voogd AC, Bot FJ, Peter Klussmann J, Huebbers CU, Hopman AHN, Ramaekers FCS, Speel E-JM. Chromosome stability in tonsillar squamous cell carcinoma is associated with HPV16 integration and indicates a favorable prognosis. Int $J$ Cancer 2013;132:1781-9.

38. Lindeberg $\mathrm{H}$, Krogdahl $\mathrm{A}$. Laryngeal dysplasia and the human papillomavirus. Clin Otolaryngol Allied Sci 1997;22:382-6.

39. Brito $\mathrm{H}$, Vassallo J, Altemani A. Detection of human papillomavirus in laryngeal squamous dysplasia and carcinoma. An in situ hybridization and signal amplification study. Acta Otolaryngol 2000;120:540-4.

40. Gallo A, Degener AM, Pagliuca G, Pierangeli A, Bizzoni F, Greco A, de Vincentiis $\mathrm{M}$. Detection of human papillomavirus and adenovirus in benign and malignant lesions of the larynx. YMHN 2009;141:276-81.

41. Laco J, Slaninka I, Jirásek $M$, Čelakovský $P$, Vošmiková $H$, Ryška A. High-risk human papillomavirus infection and p16INK4a protein expression in laryngeal lesions. Pathology - Research and Practice 2008;204:545-52. 
42. Schlecht NF, Brandwein-Gensler M, Nuovo GJ, Li M, Dunne A, Kawachi N, Smith RV, Burk RD, Prystowsky MB. A comparison of clinically utilized human papillomavirus detection methods in head and neck cancer. Mod Pathol 2011;24: 1295-305.

43. Huebbers CU, Preuss SF, Kolligs J, Vent J, Stenner M, Wieland U, Silling S, Drebber U, Speel E-JM, Klussmann JP. Integration of HPV6 and Downregulation of AKR1C3 Expression Mark Malignant Transformation in a Patient with JuvenileOnset Laryngeal Papillomatosis. PLoS ONE 2013;8:e57207.

44. Young SK, Min KW. In situ DNA hybridization analysis of oral papillomas, leukoplakias, and carcinomas for human papillomavirus. Oral Surg Oral Med Oral Pathol 1991;71:726-9.

45. Zeuss MS, Miller CS, White DK. In situ hybridization analysis of human papillomavirus DNA in oral mucosal lesions. Oral Surg Oral Med Oral Pathol 1991; 71:714-20.

46. Syrjanen SM, Syrjanen KJ, Lamberg MA. Detection of human papillomavirus DNA in oral mucosal lesions using in situ DNA-hybridization applied on paraffin sections. Oral Surg Oral Med Oral Pathol 1986;62:660-7.

47. Gage JR, Meyers C, Wettstein FO. The E7 proteins of the nononcogenic human papillomavirus type $6 \mathrm{~b}$ (HPV-6b) and of the oncogenic HPV-16 differ in retinoblastoma protein binding and other properties. Journal of Virology 1990; 64:723-30.

48. Xiong Y, Kuppuswamy D, Li Y, Livanos EM, Hixon M, White A, Beach D, TIsty TD. Alteration of cell cycle kinase complexes in human papillomavirus E6- and E7expressing fibroblasts precedes neoplastic transformation. Journal of Virology 1996;70:999-1008.

49. Helt AM, Galloway DA. Mechanisms by which DNA tumor virus oncoproteins target the Rb family of pocket proteins. Carcinogenesis 2003;24:159-69.

50. Castillo JP, Kowalik TF. Human cytomegalovirus immediate early proteins and cell growth control. Gene 2002;290:19-34.

51. Cánepa ET, Scassa ME, Ceruti JM, Marazita MC, Carcagno AL, Sirkin PF, Ogara MF. INK4 proteins, a family of mammalian CDK inhibitors with novel biological functions. IUBMB Life 2007;59:419-26.

52. Krishnamurthy J, Torrice C, Ramsey MR, Kovalev GI, Al-Regaiey K, Su L, Sharpless NE. Ink4a/Arf expression is a biomarker of aging. J Clin Invest 2004; 114:1299-307.

53. Ben-Porath I, Weinberg RA. The signals and pathways activating cellular senescence. Int J Biochem Cell Biol 2005;37:961-76.

54. Kim Sh S-H, Kaminker P, Campisi J. Telomeres, aging and cancer: in search of a happy ending. Oncogene 2002;21:503-11. 


\section{Chapter}

\section{P21 ${ }^{\text {Cip } 1 / W A F 1}$ EXPRESSION IS STRONGLY ASSOCIATED WITH HPV-POSITIVE TONSILLAR CARCINOMA AND A FAVOURABLE PROGNOSIS}

Harriët C Hafkamp*, Jeroen J Mooren*, Sandra MH Claessen, Boris Klingenberg,

Adri C Voogd, Fredrik J Bot, Jens P Klussmann, Anton HN Hopman, Johannes J Manni, Bernd Kremer,

Frans CS Ramaekers, Ernst-Jan M Speel

* These authors contributed equally to this study as first authors

Modern Pathology 2009;22:686-698 


\section{Abstract}

Human papillomavirus is involved in the carcinogenesis of tonsillar squamous cell carcinoma. Here we investigated the expression and the prognostic value of key cell cycle proteins in the retinoblastoma and p53 pathways in both human papillomavirus type 16-positive and -negative tonsillar squamous cell carcinoma. Using immunohistochemistry, 77 tonsillar squamous cell carcinoma with known human papillomavirus type 16 status and clinical outcome were analyzed for expression of Ki67, p16 ${ }^{\text {INK4A }}$, cyclin D1, retinoblastoma protein, p14 ${ }^{\mathrm{ARF}}$, MDM2, p53, p2 $1^{\mathrm{Cip} 1 / \mathrm{NAF} 1}$, and $\mathrm{p} 27^{\mathrm{KIP} 1}$. Results were correlated with each other and with clinical and demographic patient data. $35 \%$ of tonsillar squamous cell carcinoma harbored integrated human papillomavirus type 16 DNA and $\mathrm{p} 16^{\mathrm{INK} 4 \mathrm{~A}}$ overexpression, both being considered essential features for human papillomavirus association. These tumours also showed overexpression of $\mathrm{p} 14^{\mathrm{ARF}}$ $(p<0.0001)$ and $p 21^{\text {Cip1NAF1 }}(p=0.001)$, and downregulation of the retinoblastoma protein $(p<0.0001)$ and cyclin D1 $(p=0.027)$ as compared to the human papillomavirus-negative cases. Univariate Cox regression analyses revealed a favourable survival rate for nonsmokers $(p=0.006)$, as well as for patients with T1-2 tumours $(p<0.0001)$ or tumours showing low expression of cyclin D1 $(p=0.028)$, presence of human papillomavirus and overexpression of $p 16^{\text {INK4A }}(p=0.01), p 14^{\text {ARF }}(p=0.02)$ or $p 21^{\text {Cip1NAF1 }}(p=0.004)$. In multivariate regression analyses smoking and tumour size, as well as expression of cyclin D1 and p21 $1^{\text {Cip } 1 / \text { WAF1 }}$ were found to be independent prognostic markers. We conclude that human papillomavirus -positivity in tonsillar squamous cell carcinoma strongly correlates with $\mathrm{p} 21^{\mathrm{Cip} 1 / \mathrm{WAF} 1}$ and $\mathrm{p} 14^{\mathrm{ARF}}$ overexpression and downregulation of the retinoblastoma protein and cyclin D1. In particular p2 $1^{\text {Cip } 1 \text { WAF1 }}$ overexpression is an excellent favourable prognosticator in tonsillar squamous cell carcinoma. 


\section{Introduction}

Head and neck squamous cell carcinoma is the sixth most prevalent malignancy in the world, contributing $6 \%$ of new cancer cases annually worldwide. ${ }^{1,2}$ These tumours have a 5 -year survival rate of approximately $50 \%$, which has not improved in the last two decades. ${ }^{3}$ Well-recognized risk factors in the etiology of head and neck squamous cell carcinomas are extensive tobacco and alcohol consumption in $\sim 90 \%$ of cases, as well as oncogenic human papillomaviruses (HPVs), predominantly HPV type 16. ${ }^{3,4}$ Interestingly, the association of HPV is strongest for tonsillar squamous cell carcinoma (TSCC) with a prevalence up to $50 \% .^{5-8}$ The diagnosis of HPV positivity in head-andneck squamous cell carcinomas appears to have significant prognostic implications. In one study these patients had $<50 \%$ chance of dying from the disease compared with HPV-negative tumours. ${ }^{9}$

It has been shown that there are several differences between HPV-positive and -negative head and neck squamous cell carcinomas. Despite the fact that HPV positivity in head and neck squamous cell carcinomas is an indicator for favorable prognosis, from a clinical point of view these tumours are often poorly differentiated $^{4,6,10-12}$ and metastasized to lymph nodes at presentation. ${ }^{10,11}$ Furthermore, HPV-positive tumours are often smaller at first diagnosis (diameter $\leq 4 \mathrm{~cm}$ ), ${ }^{13}$ and associated with low/no exposure to alcohol and tobacco. $^{10,11}$ At the molecular level, the functional inactivation of two key tumour suppressor proteins, ie, p53 and pRb by the HPV-derived oncoproteins $E 6$ and $E 7$, often result in the downregulation of $p 53, p R b$, cyclin $D 1$, and a strong upregulation of $\mathrm{p} 16^{\mathrm{INK} 4 \mathrm{~A}}$ in HPVpositive tumours., ${ }^{5,14-16} \mathrm{HPV}$-negative tumours, in contrast, often show inactivation of $\mathrm{p} 16^{\text {INK4A }}, \mathrm{p} 53$ overexpression as a result of gene mutations, cyclin D1 gene amplification and overexpression, as well as EGFR accumulation. ${ }^{3,17-19}$

The literature, however, shows conflicting data with respect to HPV-associated characteristics and clinical outcome of head and neck squamous cell carcinomas. First, although many studies describe a significant association between HPV presence and favorable prognosis, some studies did not find such a correlation. ${ }^{20-22}$ Second, HPV has also been identified in head and neck squamous cell carcinomas of smokers, significantly reducing its favorable effect on clinical outcome. ${ }^{13}$ Furthermore, despite the fact that regional lymph node metastasis is considered as the most important prognostic factor in head and neck squamous cell carcinomas ${ }^{23}$ this parameter seems to be unreliable in tonsillar squamous cell carcinomas. ${ }^{24,25}$ Finally, some studies reported overexpression and/or p53 mutations almost exclusively in HPV-negative tumours, ${ }^{20}$ whereas others have found that HPV infection and p53 alterations can coexist. ${ }^{26}$ This may have a strong effect on survival, because it has been 
indicated that tumours with intact p53 are still capable of inducing apoptosis in response to radiation therapy, which results in a favorable clinical outcome. ${ }^{27}$

This study was undertaken to investigate the expression of key cell cycle proteins in the pRb pathway ( $\mathrm{p} 16^{\mathrm{INK} 4 \mathrm{~A}}$ cyclin $\left.\mathrm{D} 1, \mathrm{p} 27^{\mathrm{Kip} 1} \mathrm{pRb}\right)$ and the $\mathrm{p} 53$ cascade ( $p 14^{\text {ARF }}$ MDM2, p53 and p21 ${ }^{\text {Cip1/NAF1 }}$ ), using a series of 77 tonsillar squamous cell carcinomas for which the HPV16 status and the clinical followup data were available. Tonsillar squamous cell carcinomas show the highest prevalence of oncogenic HPV and are thus ideally suited to search for molecular and clinicopathological differences induced by either HPV, or tobacco and alcohol consumption.

\section{Materials and methods}

\section{Tumour material and patient data}

Formaldehyde-fixed, paraffin-embedded archival biopsy and resection material of primary tonsillar squamous cell carcinomas from 77 patients was selected from the archives of the Department of Pathology, Maastricht University Medical Center, The Netherlands. This material had been previously examined for HPV-specific DNA by means of PCR and FISH, and only showed the presence of oncogenic HPV16. ${ }^{13}$ Demographic data, including age at diagnosis, gender, alcohol and tobacco exposure, treatment modality, and date and cause of death were obtained from the medical records. Tumour site, degree of differentiation (ie, well, moderately, or poorly differentiated), and TNM classification were determined from review of pathological, radiological, and surgical reports. All patients were treated by surgery, radiotherapy, chemotherapy, or a combination, irrespective of HPV status. The study protocol was approved by the institutional ethical committee, and all patients gave informed consent. Table 3.1 provides demographic and clinical features of the 77 patients included in this study. Fifty-seven patients were male and 20 patients were female. The mean age at diagnosis was 58.8 (range 39-87) years. Data on smoking and alcohol intake were obtained from 76 and 75 patients, respectively. A total of $64(84 \%)$ of 76 patients were smokers ( $\geq 1$ cigarette, pipe, and/or cigar per day) and $46(61 \%)$ of 75 patients were classified as drinkers (consumption of $>2$ whiskey equivalents per day (one whiskey equivalent is $\sim 10 \mathrm{~g}$ alcohol)). Forty-two (55\%) patients used both tobacco and alcohol, whereas only eight $(10 \%)$ patients had not been subjected to these intoxications. Thirty-nine (51\%) patients had a tumour with a diameter $\geq 4 \mathrm{~cm}$, and $55(71 \%)$ had lymph node metastasis at the time of diagnosis. Tumour grade was poor or moderate in $63(82 \%)$ patients, well differentiated in $10(13 \%)$ patients, unavailable in 3 patients $(4 \%)$, and 1 patient $(1 \%)$ had a carcinoma in situ. Following primary treatment, $29(38 \%)$ patients 
never became disease-free, 16 (21\%) developed a recurrent disease (locoregional, regional, or distant), and 32 (42\%) patients remained diseasefree after primary treatment.

Table 3.1 Clinicopathological features and cell cycle protein expression in relation to HPV status.

\begin{tabular}{|c|c|c|c|c|}
\hline Characteristic & $\begin{array}{l}\text { All TSCC } \\
n=77(\%)\end{array}$ & $\begin{array}{c}\text { HPV-positive } \\
\text { TSCC } \\
n=27(35 \%)\end{array}$ & $\begin{array}{c}\text { HPV-negative } \\
\text { TSCC } \\
n=50(65 \%) \\
\end{array}$ & $\begin{array}{c}\text { Fisher exact } \\
\text { P-value } \\
\end{array}$ \\
\hline \multicolumn{5}{|c|}{ Cell cycle proteins } \\
\hline \multicolumn{5}{|l|}{ Ki67 } \\
\hline Positive & 75 (97\%) & $26(96 \%)$ & $49(98 \%)$ & $N S^{a}$ \\
\hline Negative & $2(3 \%)$ & $1(4 \%)$ & $1(2 \%)$ & \\
\hline \multicolumn{5}{|l|}{$\mathrm{P} 16^{\text {INK4A }}$} \\
\hline Positive & $29(38 \%)$ & $27(100 \%)$ & $2(4 \%)$ & $<0.0001$ \\
\hline Negative & $48(62 \%)$ & $0(0 \%)$ & $48(96 \%)$ & \\
\hline \multicolumn{5}{|l|}{ Cyclin D1 > 5\% } \\
\hline Positive & $33(43 \%)$ & $7(26 \%)$ & $26(52 \%)$ & 0.027 \\
\hline Negative & $44(57 \%)$ & $20(74 \%)$ & $24(48 \%)$ & \\
\hline \multicolumn{5}{|c|}{ Cyclin D1 > 50\% } \\
\hline Positive & $12(16 \%)$ & $2(7 \%)$ & $10(20 \%)$ & NS \\
\hline Negative & 65 (84\%) & $25(93 \%)$ & $40(80 \%)$ & \\
\hline \multicolumn{5}{|l|}{$\mathrm{pRb}>20 \%$} \\
\hline Positive & $62(81 \%)$ & $22(81 \%)$ & $4080 \%)$ & NS \\
\hline Negative & $15(20 \%)$ & $5(19 \%)$ & $10(20 \%)$ & \\
\hline \multicolumn{5}{|c|}{$\begin{array}{l}\text { pRb intensity in tumour } \geq \text { intensity } \\
\text { In adjacent squamous epithelium }\end{array}$} \\
\hline Positive & $41(53 \%)$ & $4(15 \%)$ & $37(74 \%)$ & $<0.0001$ \\
\hline Negative & $36(47 \%)$ & $23(85 \%)$ & $13(26 \%)$ & \\
\hline \multicolumn{5}{|l|}{$\mathrm{P} 14^{A R F}$} \\
\hline Positive & 34 (44\%) & $20(26 \%)$ & $14(18 \%)$ & $<0.0001$ \\
\hline Negative & $43(56 \%)$ & $7(9 \%)$ & $36(47 \%)$ & \\
\hline \multicolumn{5}{|l|}{ MDM2 } \\
\hline Positive & $23(30 \%)$ & $10(37 \%)$ & $13(26 \%)$ & NS \\
\hline Negative & $54(70 \%)$ & $17(63 \%)$ & 37 (74\%) & \\
\hline \multicolumn{5}{|l|}{ P53 } \\
\hline Positive & $39(51 \%)$ & $10(37 \%)$ & $29(58 \%)$ & NS \\
\hline Negative & $38(49 \%)$ & 17 (63\%) & $21(42 \%)$ & \\
\hline \multicolumn{5}{|l|}{$\mathrm{P} 21^{\text {Cip } 1 \text { NAF } 1}$} \\
\hline Positive & $32(42 \%)$ & $17(63 \%)$ & $15(30 \%)$ & 0.008 \\
\hline Negative & $43(56 \%)$ & $10(37 \%)$ & $33(66 \%)$ & \\
\hline Unknown & $2(3 \%)$ & & $2(4 \%)$ & \\
\hline \multicolumn{5}{|l|}{$\mathrm{P} 27^{\text {KIP1 }}$} \\
\hline Positive & 25 (33\%) & $9(33 \%)$ & $16(32 \%)$ & NS \\
\hline Negative & $49(64 \%)$ & $18(66 \%)$ & $31(62 \%)$ & \\
\hline Unknown & $3(4 \%)$ & & $3(6 \%)$ & \\
\hline
\end{tabular}


Table 3.1 (continued)

\begin{tabular}{|c|c|c|c|c|}
\hline Characteristic & $\begin{array}{l}\text { All TSCC } \\
n=77(\%)\end{array}$ & $\begin{array}{c}\text { HPV-positive } \\
\text { TSCC } \\
n=27(35 \%)\end{array}$ & $\begin{array}{c}\text { HPV-negative } \\
\text { TSCC } \\
\mathrm{n}=50(65 \%) \\
\end{array}$ & $\begin{array}{c}\text { Fisher exact } \\
\text { P-value } \\
\end{array}$ \\
\hline \multicolumn{5}{|c|}{ Clinicopathological variables } \\
\hline \multicolumn{5}{|l|}{ Gender } \\
\hline Female & $20(26 \%)$ & $9(33 \%)$ & $11(22 \%)$ & \multirow{2}{*}{ NS } \\
\hline Male & $57(74 \%)$ & $18(67 \%)$ & $39(78 \%)$ & \\
\hline \multicolumn{5}{|l|}{ Age (years) } \\
\hline$<60$ & $41(53 \%)$ & $13(48 \%)$ & $28(56 \%)$ & \multirow[t]{2}{*}{ NS } \\
\hline$\geq 60$ & $36(47 \%)$ & $14(52 \%)$ & $22(44 \%)$ & \\
\hline \multicolumn{5}{|l|}{ Death due to TSCC } \\
\hline Yes & $41(53 \%)$ & $8(30 \%)$ & $33(66 \%)$ & \multirow[t]{3}{*}{0.002} \\
\hline No & $33(43 \%)$ & $18(67 \%)$ & $15(30 \%)$ & \\
\hline Unknown & $3(4 \%)$ & $1(4 \%)$ & $2(4 \%)$ & \\
\hline \multicolumn{5}{|c|}{ Death due to any cause } \\
\hline Yes & $48(62 \%)$ & $10(37 \%)$ & $38(76 \%)$ & \multirow[t]{3}{*}{$<0.0001$} \\
\hline No & $26(34 \%)$ & $16(59 \%)$ & $10(20 \%)$ & \\
\hline Unknown & $3(4 \%)$ & $1(4 \%)$ & $2(4 \%)$ & \\
\hline \multicolumn{5}{|l|}{ Smoking ${ }^{a}$} \\
\hline Yes & $64(83 \%)$ & $17(63 \%)$ & $47(94 \%)$ & \multirow[t]{3}{*}{$<0.0001$} \\
\hline No & $12(16 \%)$ & $10(37 \%)$ & $2(4 \%)$ & \\
\hline Unknown & $1(1 \%)$ & & $1(2 \%)$ & \\
\hline \multicolumn{5}{|l|}{ Alcohol $^{\mathrm{b}}$} \\
\hline Yes & $46(60 \%)$ & $12(44 \%)$ & $34(68 \%)$ & \multirow[t]{3}{*}{0.024} \\
\hline No & $29(38 \%)$ & $15(56 \%)$ & $14(28 \%)$ & \\
\hline Unknown & $2(3 \%)$ & & $2(4 \%)$ & \\
\hline \multicolumn{5}{|c|}{ Smoking and/or alcohol } \\
\hline Yes & $68(88 \%)$ & $20(74 \%)$ & $48(96 \%)$ & \multirow[t]{3}{*}{0.002} \\
\hline No & $8(10 \%)$ & $7(26 \%)$ & $1(2 \%)$ & \\
\hline Unknown & $1(1 \%)$ & & $1(2 \%)$ & \\
\hline \multicolumn{5}{|c|}{ Smoking and alcohol } \\
\hline Yes & $42(55 \%)$ & $9(33 \%)$ & $33(66 \%)$ & \multirow[t]{3}{*}{0.003} \\
\hline No & $33(43 \%)$ & $18(67 \%)$ & $15(30 \%)$ & \\
\hline Unknown & $2(3 \%)$ & & $2(4 \%)$ & \\
\hline \multicolumn{5}{|l|}{ TNM-classification } \\
\hline Stage $0-3$ & $39(51 \%)$ & $13(48 \%)$ & $26(52 \%)$ & \multirow[t]{3}{*}{ NS } \\
\hline Stage 4 & $37(48 \%)$ & $14(52 \%)$ & $23(46 \%)$ & \\
\hline Unknown & $1(1 \%)$ & & $1(2 \%)$ & \\
\hline \multicolumn{5}{|l|}{ T-classification } \\
\hline$<4 \mathrm{~cm}(\mathrm{~T}$ 1-2) & $37(48 \%)$ & $17(63 \%)$ & $20(40 \%)$ & \multirow[t]{3}{*}{ NS } \\
\hline$\geq 4 \mathrm{~cm}$ (T 3-4) & $39(51 \%)$ & $10(37 \%)$ & $29(58 \%)$ & \\
\hline Unknown & $1(1 \%)$ & & $1(2 \%)$ & \\
\hline \multicolumn{5}{|l|}{ Tumour grade ${ }^{c}$} \\
\hline Poor/ moderate & $63(82 \%)$ & $24(89 \%)$ & $39(78 \%)$ & \multirow[t]{3}{*}{ NS } \\
\hline Well & $10(13 \%)$ & $2(7 \%)$ & $8(16 \%)$ & \\
\hline Unknown & $4(5 \%)$ & $1(4 \%)$ & $3(6 \%)$ & \\
\hline Lymph node meta & & & & \\
\hline Positive & $55(71 \%)$ & $22(81 \%)$ & $33(66 \%)$ & NS \\
\hline Negative & $21(27 \%)$ & $5(19 \%)$ & $16(32 \%)$ & \\
\hline Unknown & $1(1 \%)$ & & $1(2 \%)$ & \\
\hline
\end{tabular}


Table 3.1 (continued)

\begin{tabular}{|c|c|c|c|c|}
\hline Characteristic & $\begin{array}{l}\text { All TSCC } \\
n=77(\%)\end{array}$ & $\begin{array}{c}\text { HPV-positive } \\
\text { TSCC } \\
n=27(35 \%)\end{array}$ & $\begin{array}{c}\text { HPV-negative } \\
\text { TSCC } \\
n=50(65 \%)\end{array}$ & $\begin{array}{c}\text { Fisher exact } \\
\text { P-value }\end{array}$ \\
\hline \multicolumn{5}{|l|}{ Recurrent disease } \\
\hline Yes & $16(21 \%)$ & $4(15 \%)$ & $12(24 \%)$ & NS \\
\hline No & $32(42 \%)$ & $16(59 \%)$ & $16(32 \%)$ & \\
\hline Never disease free & $29(38 \%)$ & $7(26 \%)$ & $22(44 \%)$ & \\
\hline
\end{tabular}

TSCC = tonsillar squamous cell carcinoma; HPV = human papillomavrus; $\mathrm{NS}=$ not significant;

${ }^{a}$ Patiens were classified as daily tobacco smokers ( $\geq 1$ cigarette, pipe, and/or cigar per day) or nonsmokers (never smokers or patients who had stopped smoking more than 10 years before the diagnosis of TSCC); ${ }^{b}$ Patients were classified as drinkers (consumption of $>2$ whiskey equivalents per day (1 whiskey equivalent $\sim 10 \mathrm{~g}$ alcohol); ${ }^{\mathrm{C}}$ Tumour grade was scored as well-, moderately-, or poorly differentiated according to the criteria of the World Health Organization.

A series of 4- $\mu \mathrm{m}$ thick sections was cut from the specimens for hematoxylineosin staining and a detailed histopathological classification (FJB) was given according to the criteria of the World Health Organization. ${ }^{28}$ Furthermore, we applied immunohistochemistry to visualize Ki67, p16 ${ }^{\text {INK4A }}$ cyclin D1, pRb, p14 ${ }^{\text {ARF }}$ MDM2, p53, p21 ${ }^{\text {Cip1/NAF1 }}$, and p2 $7^{\text {Kip1 }}$ expression.

\section{Immunohistochemical staining}

Immunohistochemical protein staining on $4 \mu \mathrm{m}$-thick formaldehyde fixed, paraffin embedded tissue sections was performed as described earlier. ${ }^{15}$ Briefly, sections were deparaffinized and subsequently pretreated with $2 \%$ $\mathrm{H}_{2} \mathrm{O}_{2}$ in methanol for 30 minutes to quench endogenous peroxidase activity. Antigen retrieval was performed by microwave heating in 0.01-M citrate buffer (pH 6.0). The primary antibodies used to detect Ki67, p16 ${ }^{\mathrm{INK} 4 \mathrm{~A}}$, cyclin D1, pRb, p14 ${ }^{\text {ARF }}$, MDM2, p53, p2 $1^{\text {Cip1/NAF1 }}$ and $p 27^{\text {Kip1 }}$ are listed in Table 3.2. After incubation with a biotinylated secondary antibody, immunohistochemical detection was performed by an avidin-biotinylated peroxidase complex (ABC) procedure (Vectastain-Elite-ABC kit; Vector, Burlingame, USA). Peroxidase activity was detected using $0.5 \mathrm{mg} / \mathrm{ml}$ diaminobenzidine $/ 2 \% \mathrm{H}_{2} \mathrm{O}_{2}$. Sections were counterstained with hematoxylin and mounted in Entellan (Merck, Darmstadt, Germany). In each analysis negative and positive controls were included. Analysis was carried out by three independent observers (JJM, EJMS and $\mathrm{SMHC}$ ) and in case of interobserver variations, consensus was reached by combined examination of the slides. Both staining intensity $(-,+/-,+,++,+++)$ and the percentage of stained tumour cells were scored. Evaluation criteria for positive scoring of each of the cell cycle proteins are listed in Table 3.2. 


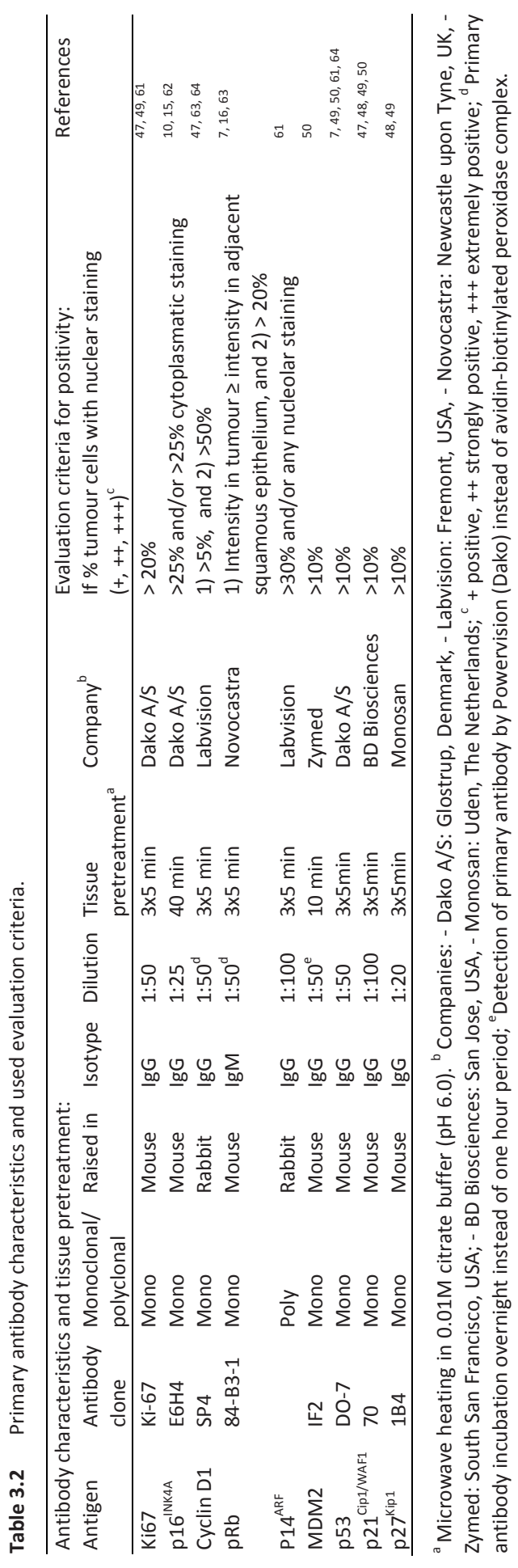




\section{Statistical analysis}

The study population consisted of 77 patients with a tonsillar squamous cell carcinoma diagnosed between 1992 and 2001. Tumours were considered to be HPV-associated if they showed HPV16 presence by in situ hybridization analysis, in addition overexpression of $\mathrm{p} 16^{\mathrm{INK} 4 \mathrm{~A}}$, as detected by immunohistochemistry. Factors associated with HPV status were selected on crosstabulations, which were analyzed by the use of the two-tailed Fisher's exact test and/or $\chi^{2}$-square test. The maximum significance levels are indicated for all analyses $(p \leq 0.05)$. Disease-specific survival curves were calculated using the Kaplan-Meier method. Survival was calculated from the date of diagnosis until patient's death or until the last date the patient was known to be alive (this ranged from 16-141 months). Patients who died of other causes than tonsillar carcinoma were considered censored observations in the disease-specific survival analyses. Disease-free survival was calculated from the date of diagnosis until the date of recurrence (local, regional or distant, whichever occurred first). Patients without recurrence were censored at the date of the last follow-up or the date of death. The statistical significance of differences between survival times as determined by the log rank test in univariate analysis. Multivariate analyses were performed using the Cox proportional hazards model. Variables in the multivariate model included: HPV association,

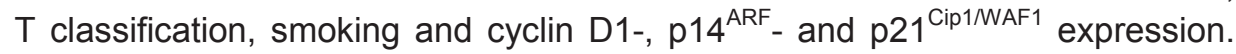
Variables remained in the model if their $p$-values were $<0.10$. All calculations were performed by use of the SPSS Base System version 12.0.1.

\section{Results}

\section{Cell cycle protein expression}

Seventy-seven tonsillar squamous cell carcinomas were examined for expression of the cell cycle proteins Ki67, p16 ${ }^{\text {INK4A }}$, cyclin D1, pRb, p14 ${ }^{\text {ARF }}$,

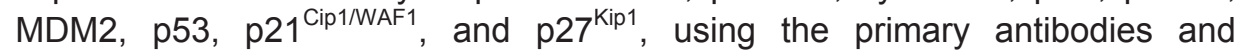
evaluation criteria stated in Table 3.2. Representative immunostaining results in normal epithelium and tumour tissues are shown in Figure 3.1. The frequency of tumours exhibiting expression of the respective proteins is presented in Figure 3.2A. In all, 75 out of 77 (97\%) tonsillar squamous cell carcinomas showed strong, nuclear Ki67 expression in 30-90\% of the tumour cells (Figure 3.1A). Also nuclear pRb staining was often observed in tonsillar carcinoma (62 out of 77 cases, $81 \%$ ), although two subsets were identified with a difference in staining intensity (i.e., tumours showing $<$ or $\geq$ intense immunostaining than present in the adjacent squamous epithelium. Figure 3.1D and $3.1 \mathrm{~J}$, respectively). A significant association was seen between 
overexpression of $\mathrm{pRb}$ (a higher nuclear staining intensity in tumour cells than in the adjacent normal squamous epithelium) and p53 accumulation ( $p=0.017)$. Both overexpression of $p 53$ and $p 21^{\text {Cip1/NAF1 }}$ correlated independently with the accumulation of MDM2 (Figure $3.1 \mathrm{~K})(p=0.030$ and $p=0.004$, respectively), but not with each other (data not shown; Supplementary Table S3.1). In addition, there was a significant association between overexpression of $\mathrm{p} 16^{\mathrm{INK} 4 \mathrm{~A}}$ and that of both $\mathrm{p} 14^{\mathrm{ARF}}(\mathrm{p}<0.0001)$ and $\mathrm{p} 21^{\text {Cip } 1 \text { /NAF1 }}(\mathrm{p}=0.027)$ (Figure $3.1 \mathrm{~B}, 3.1 \mathrm{C}$ and $3.1 \mathrm{~F})$. In case of $\mathrm{p} 14^{\mathrm{ARF}}$ overexpression in the tumour, a diffuse nuclear staining pattern was more often observed than nucleolar staining (Figure 3.1C, above and below, respectively). Furthermore, $\mathrm{p} 16^{\text {INK4A }}$ accumulation strongly correlated with both downregulation of $p R b(p<0.0001)$ and cyclin D1 $(p=0.035)$ (Figure 3.1D and 3.1E).

Staining of normal tonsillar squamous epithelium was seen in the basal or parabasal cell layers for Ki67, cyclin $\mathrm{D} 1, \mathrm{pRb}, \mathrm{p} 21^{\text {Cip1/NAF1 }}$, and p53, varying from low to high intensities (Figure 3.1A, 3.1B, 3.1D-G). This squamous epithelium, present in the individual sections, was used as an internal positive control. In p14 ${ }^{\mathrm{ARF}}$ - and $\mathrm{p} 27^{\mathrm{Kip} 1}$-stained sections, adjacent lymphocyte infiltration often showed a strong cytoplasmatic and nuclear staining, respectively, and therefore served as the internal positive control (Figure 3.1L).

\section{Correlations between HPV status, expression of cell cycle proteins and clinicopathological variables}

The correlations between each cell cycle marker and HPV status are shown in Table 3.1 and Figure 3.2B. HPV-associated tonsillar squamous cell carcinoma showed significantly more often overexpression of $p 14^{\mathrm{ARF}}(p<0.0001)$ and $p 21^{\text {Cip } 1 \text { WAF1 }}(p=0.008)$, and downregulation of $p R b(p<0.0001)$ and cyclin D1 $(p=0.027)$ than HPV-negative tumours. P53 accumulation tended to be associated with absence of HPV $(p=0.079)$.

The male/female ratio and the age distribution were similar for the HPV-positive and HPV-negative subgroups. Smoking and alcohol abuse were seen significantly more often in the HPV-negative patient group $(p<0.0001$ and $p=0.024$, respectively). HPV-positive tumours tended to be smaller than HPV-negative tumours $(p=0.065)$. Male patients were more often diagnosed with a T3-4 tumour $(p=0.006)$ and were more often smokers $(p=0.011)$. 


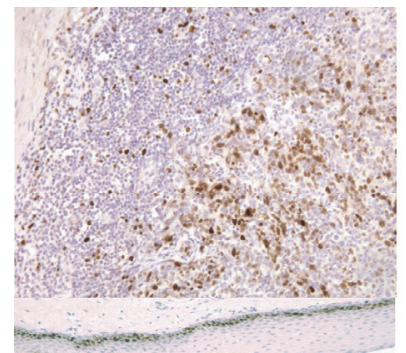

A
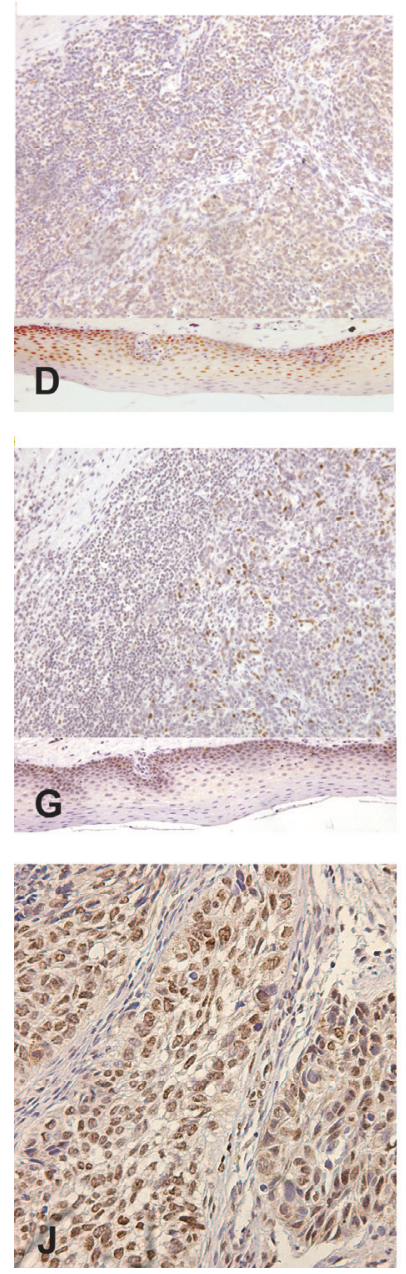
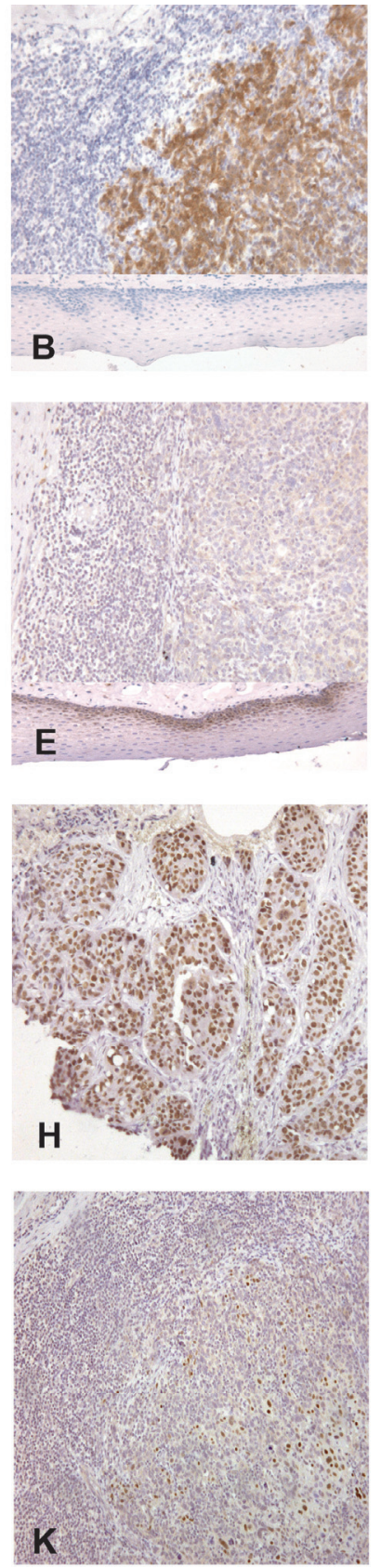
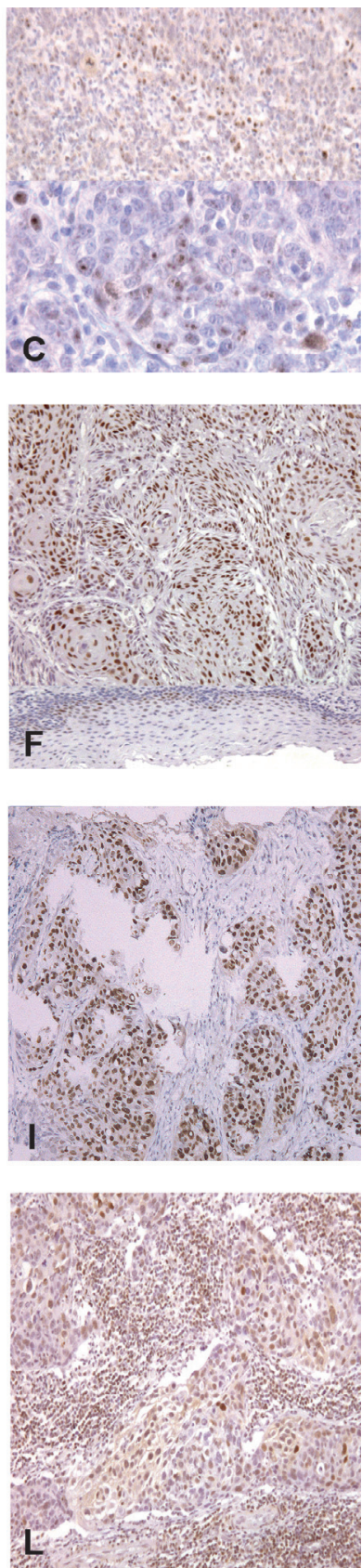

Figure 3.1 Representative examples of immunohistochemical staining on tissue sections for (A) Ki67, (B) p16 ${ }^{\mathrm{INK} 4 \mathrm{~A}},(\mathbf{C}) \mathrm{p} 14^{\mathrm{ARF}},(\mathbf{D}, \mathbf{J}) \mathrm{pRb},(\mathbf{E}, \mathbf{I})$ Cyclin D1, (F) p2 $1^{\mathrm{Cip} 1 / \mathrm{NAF} 1},(\mathbf{G}, \mathbf{H}) \mathrm{p} 53$, (K) MDM2 and (L) p2 $7^{\text {Kip1 }}$. Sections are from HPV-positive tonsillar squamous cell carcinoma (A-G), HPV-negative tonsillar squamous cell carcinoma $(\mathbf{H}-\mathbf{L})$ and adjacent squamous epithelium (A, B, D-G; lower image). Evaluation criteria as described in 


\begin{abstract}
Materials and Methods section. (A) Strong nuclear Ki67 staining in tumour cells and parabasal epithelial cells; (B) Strong and diffuse $\mathrm{p} 16^{\mathrm{INK} 4 \mathrm{~A}}$ staining in tumour cells, predominantly cytoplasmatic; epithelium negative; (C) Strong and diffuse nuclear $\mathrm{p} 14^{\mathrm{ARF}}$ staining (higher image). Some tumours show a rather nucleolar-like immunostaining (lower image). (D) Weak/no nuclear pRb staining in tumour cells in comparison with adjacent normal squamous epithelium. (E) Weak/no nuclear cyclin D1 staining in tumours cells; parabasal epithelial cells weakly positive; (F) Strong nuclear p21 ${ }^{\text {Cip1NAF1 }}$ staining in tumour cells; some (para)basal epithelial cells weakly positive; (G) Low frequency of tumour cells positive for nuclear p53; some (para)basal epithelial cells weakly positive; $(\mathbf{H})$ High frequency of tumour cells positive for nuclear p53; (I) High frequency of tumour cells positive for nuclear cyclin D1; (J) Strong nuclear $\mathrm{pRb}$ staining in tumour cells; (K) Low frequency of tumour cells showing strong and nuclear MDM2 staining; (L) Weak to strong nuclear immunostaining for p27Kip1 in tumour cell areas as well as in adjacent lymphocyte areas.

Magnification: 40x (A-C (higher image), D-I, K-L), 120x (J) and 200x (C (lower image)).
\end{abstract}

\title{
Indicators for disease-specific patient survival
}

To determine whether or not cell cycle protein expression patterns and clinicopathological parameters can be used as indicators of prognosis, we correlated these with the disease-specific survival data of patients with tonsillar squamous cell carcinoma (Table 3.3). Two patients died post-operatively, due to bleeding and aspiration, and from one patient no follow-up data were available. These patients were excluded from the analyses. Follow-up time ranged from 0 to 141 months, with a mean of 30 months. A total of $41(55 \%)$ of 74 patients died as a consequence of tonsillar carcinoma. The survival after 5 years was $31 \%$ for patients with a HPV-negative tumour and $69 \%$ for patients with a HPV-positive carcinoma (Hazard ratio $(H R)=0.4 ; 95 \%$ confidence interval $(\mathrm{Cl})=0.2-0.8)$. Besides the absence of HPV, the following parameters were also significantly associated with a shorter disease-specific survival according to Univariate Cox regression analysis: 1) smoking ( $\mathrm{HR}=5.8 ; 95 \% \mathrm{Cl}=1.4-24.1)$, 2) a tumour diameter $\geq 4 \mathrm{~cm}(\mathrm{HR}=3.1 ; 95 \% \mathrm{Cl}=1.6-6.0)$, 3) development of recurrent disease $(\mathrm{HR}=14.1 ; 95 \% \mathrm{Cl}=3.9-51.1), 4)$ no/low expression of either $\mathrm{p} 14^{\mathrm{ARF}}(\mathrm{HR}=2.2 ; 95 \% \mathrm{Cl}=1.1-4.3)$ or $\mathrm{p} 21^{\mathrm{Cip} 1 \text { NAF1 }}(\mathrm{HR}=2.7 ; 95 \% \mathrm{Cl}=1.3-5.5)$, and 5 ) positive cyclin D1 immunostaining in $>50 \%$ of tumour cells (HR=2.2; 95\% Cl=1.1-4.7). Gender, age at diagnosis, alcohol use, tumour grade, TNM-stage, lymph node status, and the remaining cell cycle markers were not related to disease-specific survival.

The parameters that were significantly correlated with disease-specific survival in the univariate analysis, i.e. HPV-status, tumour size, smoking, and immunostaining of $\mathrm{p} 14^{\mathrm{ARF}}, \mathrm{p} 21^{\mathrm{Cip} 1 \mathrm{NAF} 1}$ and cyclin D1, were included in the multivariate Cox regression analysis. Development of recurrent disease was not included for multivariate analysis, because this factor cannot be predicted at time of diagnosis, so the clinical impact is of less importance. Table 3.4 shows that four of the six parameters, i.e. tobacco consumption, tumour diameter $\geq 4 \mathrm{~cm}$, no/low p21 $1^{\text {Cip1/NAF1 }}$ immunostaining, or strong cyclin D1 
immunostaining, were the most optimal indicators of cancer-specific death, with tumour size and $221^{\text {Cip } 1 \text { MAF1 }}$ immunostaining being the most significantly correlated. In Figure 3.3 the Kaplan-Meier curves for these four parameters are shown.

A
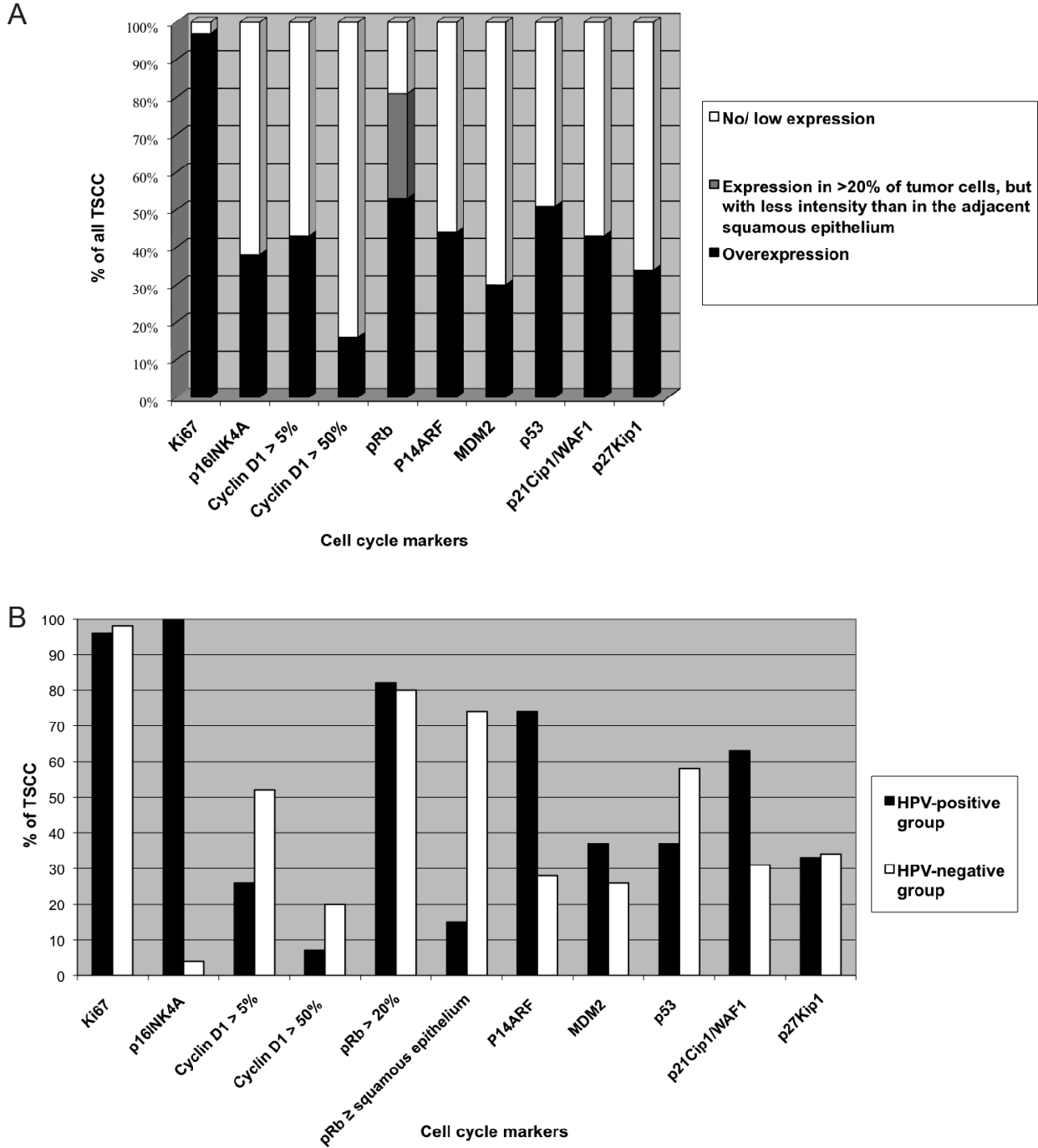

Figure 3.2 (A) Cell cycle protein expression in tonsillar squamous cell carcinoma according to the evaluation criteria presented in Table 3.2. (B) Fraction of HPV-positive and HPV-negative tonsillar squamous cell carcinoma showing expression of individual cell cycle markers. See table 3.2 for the used criteria for positivity of each individual cell cycle marker. 
Table 3.3 Influence of HPV-related and clinicopathologic parameters on disease-specific survival in 74 patients with TSCC, as determined by univariate Cox proportional hazard regression analysis.

\begin{tabular}{|c|c|c|c|c|}
\hline Variable & Total & Death & $\mathrm{P}$ value ${ }^{\mathrm{a}}$ & $\begin{array}{c}\text { Unadjusted HR } \\
(95 \% \mathrm{CI})\end{array}$ \\
\hline \multicolumn{5}{|c|}{ Cell cycle proteins } \\
\hline \multicolumn{5}{|l|}{ Ki67 } \\
\hline Positive & 72 & $40(56 \%)$ & \multirow[t]{2}{*}{$N S^{b}$} & $1.5(0.2-10.9)$ \\
\hline Negative & 2 & $1(50 \%)$ & & 1 (referent) \\
\hline \multicolumn{5}{|l|}{$\mathrm{P} 16^{\text {INK } 4 \mathrm{~A}}$} \\
\hline Positive & 28 & $10(36 \%)$ & \multirow{2}{*}{0.029} & $0.5(0.2-0.9)$ \\
\hline Negative & 46 & $31(67 \%)$ & & 1 (referent) \\
\hline \multicolumn{5}{|c|}{ Cyclin D1 >5\% } \\
\hline Positive & 31 & $20(65 \%)$ & \multirow{2}{*}{0.060} & $1.8(1.0-3.4)$ \\
\hline Negative & 43 & $21(49 \%)$ & & 1 (referent) \\
\hline \multicolumn{5}{|c|}{ Cyclin D1 >50\% } \\
\hline Positive & 11 & $9(82 \%)$ & \multirow[t]{2}{*}{0.028} & $2.2(1.1-4.7)$ \\
\hline Negative & 63 & $32(51 \%)$ & & 1 (referent) \\
\hline \multicolumn{5}{|l|}{$\mathrm{pRb}>20 \%$} \\
\hline Positive & 61 & $35(57 \%)$ & \multirow[t]{2}{*}{ NS } & $1.5(0.6-3.5)$ \\
\hline Negative & 13 & $6(46 \%)$ & & 1 (referent) \\
\hline \multicolumn{5}{|c|}{$\mathrm{pRb}$ intensity in tumour $\geq$ intensity } \\
\hline Positive & 40 & $25(62 \%)$ & \multirow[t]{2}{*}{ NS } & $1.5(0.8-2.9)$ \\
\hline Negative & 34 & $16(47 \%)$ & & 1 (referent) \\
\hline \multicolumn{5}{|l|}{$\mathrm{P} 14^{\mathrm{ARF}}$} \\
\hline Positive & 33 & $12(36 \%)$ & \multirow[t]{2}{*}{0.020} & $0.5(0.2-0.9)$ \\
\hline Negative & 41 & $29(71 \%)$ & & 1 (referent) \\
\hline \multicolumn{5}{|l|}{ MDM2 } \\
\hline Positive & 22 & $10(45 \%)$ & \multirow[t]{2}{*}{ NS } & $0.8(0.4-1.7)$ \\
\hline Negative & 52 & $31(60 \%$ & & 1 (referent) \\
\hline \multicolumn{5}{|l|}{ P53 } \\
\hline Positive & 37 & $22(59 \%)$ & \multirow[t]{2}{*}{ NS } & $1.2(0.7-2.2)$ \\
\hline \multirow{2}{*}{\multicolumn{5}{|c|}{$\mathrm{p} 21^{\text {Cip1/NAF1 }}$}} \\
\hline & & & & \\
\hline Positive & 30 & $10(33 \%)$ & \multirow[t]{2}{*}{0.004} & $0.4(0.2-0.8)$ \\
\hline Negative & 43 & $31(72 \%)$ & & 1 (referent) \\
\hline Unknown & 1 & & & \\
\hline \multicolumn{5}{|l|}{$\mathrm{P} 27^{\mathrm{KIP} 1}$} \\
\hline Positive & 25 & $14(66 \%)$ & NS & $1.2(0.6-2.3)$ \\
\hline Negative & 47 & $26(55 \%)$ & & 1 (referent) \\
\hline Unknown & 2 & & & \\
\hline & & & & \\
\hline Gender & & & & \\
\hline Male & 55 & $33(60 \%)$ & 0,084 & 1 (referent) \\
\hline Female & 19 & $8(42 \%)$ & & $1,9(0,9-4,2)$ \\
\hline Age (years) & & & & \\
\hline$<60$ & 41 & $24(58 \%)$ & NS & 1 (referent) \\
\hline$\geq 60$ & 33 & $17(52 \%)$ & & $0.8(0.4-1.5)$ \\
\hline Smoking $^{\mathrm{b}}$ & & & & \\
\hline No & 11 & $2(18 \%)$ & 0,006 & 1 (referent) \\
\hline Yes & 63 & $39(62 \%)$ & & $5.8(1.4-24.1)$ \\
\hline Alcohol $^{\mathrm{C}}$ & & & & \\
\hline No & 29 & $16(55 \%)$ & NS & 1 (referent) \\
\hline Yes & 45 & $25(56 \%)$ & & $1.1(0.6-2.0)$ \\
\hline
\end{tabular}


Table 3.3 (continued)

\begin{tabular}{|c|c|c|c|c|}
\hline Variable & Total & Death & $P$ value $^{a}$ & $\begin{array}{c}\text { Unadjusted HR } \\
(95 \% \mathrm{Cl})\end{array}$ \\
\hline \multicolumn{5}{|l|}{ Smoking and/or alcohol } \\
\hline No & 8 & $1(12 \%)$ & \multirow[t]{2}{*}{0,015} & 1 (referent) \\
\hline Yes & 66 & $40(61 \%)$ & & $7.9(1.1-57.7)$ \\
\hline \multicolumn{5}{|l|}{ Smoking and alcohol } \\
\hline No & 32 & $17(53 \%)$ & \multirow[t]{2}{*}{ NS } & 1 (referent) \\
\hline Yes & 42 & $24(57 \%)$ & & $1.3(0.7-2.3)$ \\
\hline \multicolumn{5}{|l|}{ TNM-classification } \\
\hline Stage $0-3$ & 38 & $20(53 \%)$ & \multirow[t]{2}{*}{ NS } & 1 (referent) \\
\hline Stage 4 & 36 & $21(58 \%)$ & & $1.5(0.8-2.8)$ \\
\hline \multicolumn{5}{|l|}{ T-classification } \\
\hline$<4 \mathrm{~cm}(\mathrm{~T} \mathrm{1-2})$ & 35 & $14(40 \%)$ & \multirow[t]{2}{*}{$<0.001$} & 1 (referent) \\
\hline$\geq 4 \mathrm{~cm} \mathrm{(T} \mathrm{3-4)}$ & 39 & $27(69 \%)$ & & $3.1(1.6-6.0)$ \\
\hline \multicolumn{5}{|l|}{ Tumour grade ${ }^{d}$} \\
\hline Poor/ moderate & 61 & $37(61 \%)$ & \multirow[t]{3}{*}{ NS } & 1 (referent) \\
\hline Well & 10 & $3(30 \%)$ & & $0.4(0.1-1.4)$ \\
\hline Unknown & 3 & & & \\
\hline \multicolumn{5}{|c|}{ Lymph node metastasis } \\
\hline Positive & 54 & $29(54 \%)$ & \multirow[t]{2}{*}{ NS } & $1.0(0.5-1.9)$ \\
\hline Negative & 20 & $12(60 \%)$ & & 1 (referent) \\
\hline \multicolumn{5}{|l|}{ Recurrent disease } \\
\hline Yes & 16 & $13(81)$ & \multirow[t]{3}{*}{$<0.0001$} & 1 (referent) \\
\hline No & 32 & $3(9 \%)$ & & $14.1(3.9-51.1)$ \\
\hline Never disease free & 26 & $25(96 \%)$ & & \\
\hline \multicolumn{5}{|l|}{ HPV-association } \\
\hline Yes & 26 & $8(31 \%)$ & \multirow[t]{2}{*}{0.010} & $0.4(0.2-0.8)$ \\
\hline No & 48 & $33(69 \%)$ & & 1 (referent) \\
\hline
\end{tabular}

$\mathrm{HR}=$ hazard ratio; NS = not significant; HPV = human papillomavrus. ${ }^{\text {a }}$ P-values based on the Log Rank test; ${ }^{\mathrm{b}}$ Patiens were classified as daily tobacco smokers ( $\geq 1$ cigarette, pipe, and/or cigar per day) or non-smokers (never smokers or patients who had stopped smoking more than 10 years before the diagnosis of TSCC); ${ }^{\circ}$ Patients were classified as drinkers (consumption of $>2$ whiskey equivalents per day (1whiskey equivalent $\approx 10 \mathrm{~g}$ alcohol); ${ }^{\mathrm{d}}$ Tumour grade was scored as well-, moderately-, or poorly differentiated according to the criteria of the World Health Organization.

Table 3.4 Multivariate analysis, according to Cox proportional hazard regression analysis, of the patient and tumour characteristics related to disease-specific mortality.

\begin{tabular}{lccc}
\hline Characteristic & HR & $95 \% \mathrm{Cl}$ & P-value \\
\hline Smoking: yes vs. no & 4.06 & $0.95-17.26$ & 0.058 \\
Tumour size: T3-4 vs. T1-2 & 2.58 & $1.32-5.07$ & 0.006 \\
p21 1 Cip1MAF1 : positive vs. negative & 0.38 & $0.18-0.79$ & 0.009 \\
Cyclin D1: $>50 \%$ vs. $\leq 50 \%{ }^{a}$ & 2.19 & $1.02-4.69$ & 0.044 \\
\hline
\end{tabular}

$\mathrm{HR}=$ hazard ratio; $\mathrm{Cl}=$ confidence interval. ${ }^{\mathrm{a}}$ Nuclear staining. 


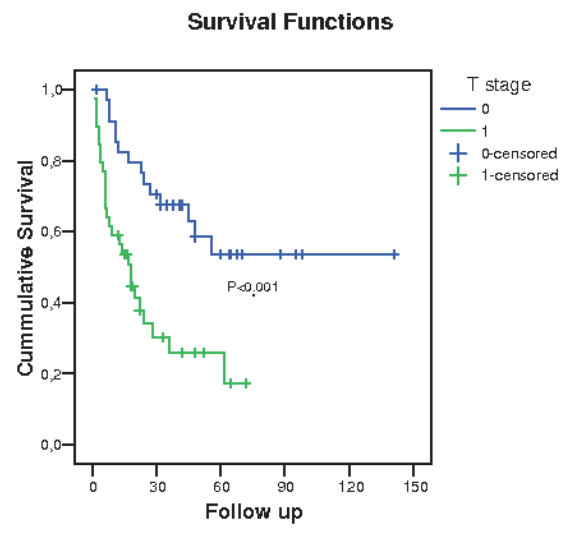

C

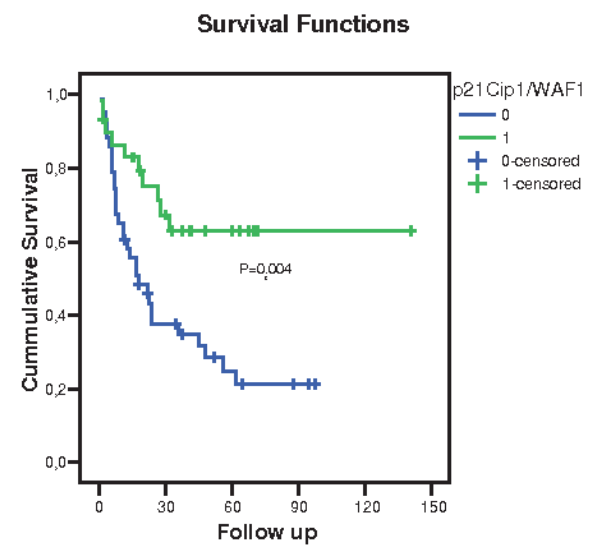

B

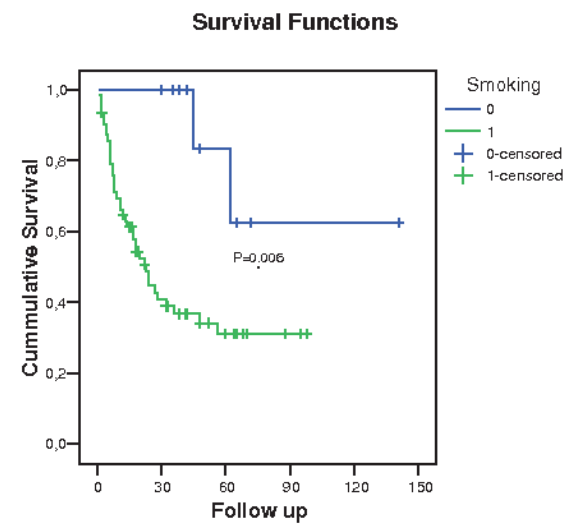

D

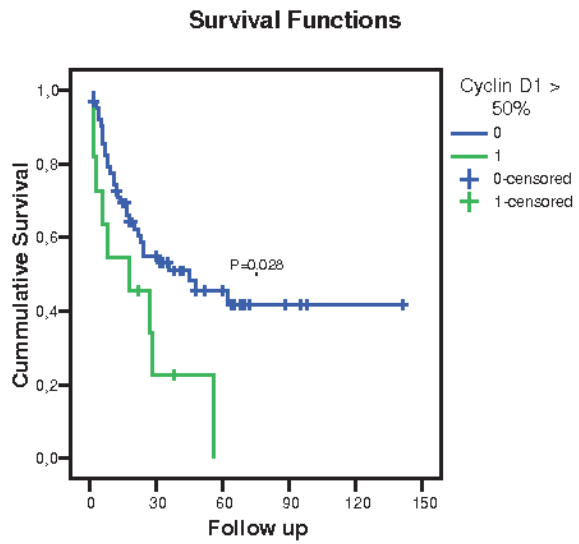

Figure 3.3 Kaplan-Meier survival curves according to (A) tumour size, (B) smoking status, (C) $221^{\text {Cip1/WAF } 1}$ expression, and (D) strong cyclin D1 expression.

\section{Discussion}

In this study we examined the expression of cell cycle-related constituents in a series of 77 tonsillar squamous cell carcinoma with the goal to determine their role in HPV-dependent and HPV-independent carcinogenesis. Furthermore, their prognostic value was evaluated by correlating the results with clinical follow-up data. Our results show that HPV16-positive tumours exhibit $\mathrm{p} 14^{\mathrm{ARF}}$ and $\mathrm{p} 21^{\text {Cip } 1 \text { /WAF } 1}$ overexpression and downregulation of $\mathrm{pRb}$ and cyclin D1 in 
contrast to HPV16-negative tumours. Secondly, tumour size and p21 Cip1/WAF1 positivity are the strongest independent indicators for a favourable outcome in patients with tonsillar squamous cell carcinoma.

All tonsillar squamous cell carcinoma, except one HPV-positive and one HPV-negative tumour, showed a high expression of Ki67, indicating that almost all tumours contained a high percentage of proliferative cells, which is in agreement with other studies on head and neck squamous cell carcinomas. ${ }^{37}$ In addition, high expression levels of inhibitors of apoptosis, such as $B c I X_{L}$ and survivin, have been reported in head and neck squamous cell carcinoma. ${ }^{38-41}$ Expression of $\mathrm{pRb}$ was detected in $81 \%$ of the tumours. Approximately half of all tumours showed strong nuclear expression in the tumour cells, with expression levels equal to or higher than the adjacent normal squamous epithelium, whereas $\mathrm{pRb}$ downregulation was observed in the remaining cases. In our study p53 overexpression was observed in little more than half of all tonsillar carcinomas, which is consistent with other studies. ${ }^{7,42}$ Immunostaining of all other cell cycle proteins was evident in less than $50 \%$ of tumours.

We noticed that the tumours with the low expression levels of $p R b$ showed overexpression of $\mathrm{p} 16^{\mathrm{INK} 4 \mathrm{~A}}$. Accumulation of this latter protein has been strongly associated with the presence of oncogenic HPV in oropharyngeal carcinomas, ${ }^{7,10,14,15}$ which was also evident in the underlying study. These HPV16-positive tonsillar squamous cell carcinoma furthermore showed downregulation of cyclin D1, next to accumulation of $\mathrm{p} 14^{\mathrm{ARF}}$ and $\mathrm{p} 21^{\text {Cip } 1 \text { NAF } 1}$. In addition, p53 expression was less profound in these HPV-positive tumours.

In HPV-associated tumours the oncoprotein E7 interacts with $\mathrm{pRb}$, resulting in its degradation. As a result, $\mathrm{p} 16^{\mathrm{INK} 4 \mathrm{~A}}$ is upregulated and cyclin D1 downregulated. ${ }^{43}$ This is in agreement with Andl et al., ${ }^{5}$ who suggested that E7 might overcome the need for cyclin D1 in the G1 phase of the cell cycle, because it interacts with the cyclin D1-binding site on $\mathrm{pRb}^{7,44}$ Indeed, high expression levels of cyclin D1 were predominantly observed in HPV-negative tonsillar carcinomas, most probably pointing to cyclin D1 gene amplification in these cases.

The $\mathrm{p} 14^{\mathrm{ARF}}$ gene is a target for the transcription factor E2F, which promotes its expression particularly in the HPV-positive tumours, as has become evident in this study. In the HPV-negative tumours both $\mathrm{p} 14^{\mathrm{ARF}}$ as well as $\mathrm{p} 16^{\mathrm{INK} 4 \mathrm{~A}}$ were often undetectable, which is in accordance with the fact that their expression is downregulated in most head and neck squamous cell carcinomas due to gene inactivation at the $9 \mathrm{p} 21$ locus. ${ }^{45,46}$ In normal tissue cells, p14 ${ }^{\text {ARF }}$ upregulation might lead to p53 upregulation, but in HPV-positive tonsillar squamous cell carcinomas this is usually counteracted by means of functional inactivation of wild-type p53 by the viral E6 protein. In contrast and as observed in our study, p53 is frequently upregulated in HPV-negative tumours due to mutations in the TP53 gene as a result of exposure to tobacco and/or alcohol. ${ }^{10,16,20,27,47}$ 
Although $\mathrm{p} 21^{\text {Cip } 1 \text { WAF } 1}$ is known to be a downstream effector of $\mathrm{p} 53,{ }^{48,49}$ it was surprising to find overexpression in HPV-positive tumours harboring low or no detectable levels of p53. Such observations have also been reported by MildeLangosch et al. ${ }^{50}$ in HPV-associated uterine cervical tumours and suggest that also p53-independent mechanisms may lead to p21 $1^{\text {Cip } 1 \text { WAF1 }}$ accumulation as described previously. ${ }^{51,52}$ Indeed, in HPV-positive cancer cells, p21 ${ }^{\text {Cip1/WAF1 }}$ expression appears to be inducible, ${ }^{53}$ although it remains unclear why under these conditions E7 cannot inactivate p21 ${ }^{\text {Cip } 1 \text { NAF1 } 1}$ by direct interaction. ${ }^{14}$

Despite the strong association of p21 Cip1/NAF1 overexpression with HPV-positivity in most tonsillar squamous cell carcinomas, we found p21 ${ }^{\text {Cip } 1 \text { NAF } 1}$ protein accumulation also in some HPV-negative tumours, which is in accordance with a study of $\mathrm{Li}$ et al. ${ }^{54}$ These authors examined 67 tonsillar squamous cell carcinomsa for HPV involvement but did not find p21 Cip1/WAF1 expression being associated with HPV-positivity. An explanation for this paradox might be on the one hand the use of a different p21 ${ }_{\text {Cip1/WAF } 1}$-specific primary antibody and different criteria to assess $221^{\text {Cip } 1 \text { WAF } 1}$ upregulation $(>20 \%$ of positive nuclei versus $>10 \%$ ) in comparison with our and other studies, ${ }^{29,20,25,36}$ and on the other hand the use of only PCR to determine the presence of HPV. To to assess a firm association between virus and tumour cells, namely, it is recommended to carry out additional tests, such as p16 INK4A immunostaining and/ or FISH, which has been applied in our study. ${ }^{55-56}$

In the univariate and multivariate statistical analyses we found that $\mathrm{p} 21^{\text {Cip } 1 \text { WAF } 1}$ overexpression was a highly significant indicator of favourable prognosis in tonsillar squamous cell carcinoma independent of HPV status. Expression of p21 ${ }^{\text {Cip } 1 \text { WAF } 1}$ has also been associated with a favourable survival in patients with tongue squamous cell carcinomas, and in patients with ovarian, superficial bladder, gastric, colorectal and esophageal cancers..$^{29,43,57,58}$ In one other study on tonsillar squamous cell carcinomas and two studies on laryngeal squamous carcinomas no correlation was reported ${ }^{36,54,59}$ and in one study on head and neck squamous cell carcinomas derived from multiple head and neck localizations even a negative correlation with survival was described ${ }^{19}$, which may be explained by the heterogeneous tumour population. Other strong indicators for a favourable prognosis in our study include tumour diameter $<4 \mathrm{~cm}$, low/no expression of cyclin D1, and low/no tobacco consumption. In accordance with most other studies on HPV-related oropharyngeal carcinomas, we also found a favourable disease-specific survival in patients with HPV16-positive tonsillar squamous cell carcinomas, ${ }^{12,46,60-64}$ and $\mathrm{p} 14^{\mathrm{ARF}}$ overexpression, ${ }^{31}$ although with less significance than the indicators described above. We noticed that lymph node status, which is generally considered as the most important prognostic factor in head and neck squamous cell carcinoma, ${ }^{23}$ had little value in our series of tonsillar squamous cell carcinomas, which is in concordance with other studies. ${ }^{24,25}$ 
In summary we can conclude that HPV16-positive tonsillar squamous cell carcinomas exhibit overexpression of $\mathrm{p} 14^{\mathrm{ARF}}$ and $\mathrm{p} 21^{\mathrm{Cip} 1 / \mathrm{WAF} 1}$, as well as downregulation of $\mathrm{pRb}$ and cyclin $\mathrm{D} 1$, and that strong immunostaining for p21 $1^{\text {Cip1NAF1 }}$ appears to be one of the most potent indicators for favourable prognosis in these tumours. 


\section{References}

1. Parkin DM, Pisani P, Ferlay J. Estimates of the worldwide incidence of 25 major cancers in 1990. Int J Cancer 1999;80:827-41.

2. St John MA, Abemayor E, Wong DT. Recent new approaches to the treatment of head and neck cancer. Anticancer Drugs 2006;17:365-75.

3. Mao L, Hong WK, Papadimitrakopoulou VA. Focus on head and neck cancer. Cancer Cell 2004;5:311-6.

4. Forastiere A, Koch W, Trotti A, et al. Head and neck cancer. $N$ Engl $J$ Med 2001;345:1890-900.

5. Andl T, Kahn T, Pfuhl A, et al. Etiological involvement of oncogenic human papillomavirus in tonsillar squamous cell carcinomas lacking retinoblastoma cell cycle control. Cancer Res 1998;58:5-13.

6. Wilczynski SP, Lin BTY, Xie Y, et al. Detection of human papillomavirus DNA and oncoprotein overexpression are associated with distinct morphological patterns of tonsillar squamous cell carcinoma. Am J Pathol 1998;152:145-56.

7. Li W, Thompson $\mathrm{CH}$, Cossart YE, et al. The expression of key cell cycle markers and presence of human papillomavirus in squamous cell carcinoma of the tonsil. Head Neck 2004;26:1-9.

8. Mellin H, Friesland S, Lewensohn R, et al. Human papillomavirus (HPV) DNA in tonsillar cancer: clinical correlates, risk of relapse and survival. Int $J$ Cancer 2000;89:300-4.

9. Fakhry C, Gillison ML. Clinical implications of human papillomavirus in head and neck cancers. J Clin Oncol 2006;24:2606-11.

10. Hafkamp HC, Speel EJ, Haesevoets A, et al. A subset of head and neck squamous cell carcinomas exhibits integration of HPV 16/18 DNA and overexpression of p16INK4A and p53 in the absence of mutations in p53 exons 5-8. Int $J$ Cancer 2003;107:394-400.

11. Klussmann JP, Weissenborn SJ, Wieland $U$, et al. Prevalence, distribution, and viral load of human papillomavirus 16 DNA in tonsillar carcinomas. Cancer 2001;92:2875-84.

12. Ritchie JM, Smith EM, Summersgill KF, et al. Human papillomavirus infection as a prognostic factor in carcinomas of the oral cavity and oropharynx. Int $J$ Cancer 2003; 104:336-44.

13. Hafkamp HC, Manni JJ, Haesevoets A, et al. Marked differences in survival rate between smokers and non-smokers with HPV 16-associated tonsillar carcinomas. Int J Cancer 2008;122:2656-64.

14. Zur Hausen $\mathrm{H}$. Papillomaviruses and cancer. from basic studies to clinical application. Nat Rev Cancer 2002;2:342-50.

15. Klussmann JP, Gültekin E, Weissenborn SJ, et al. Expression of p16 protein identifies a distinct entity of tonsillar carcinomas associated with human papillomavirus. Am J Pathol 2003;162:747-53.

16. Wiest T, Schwartz E, Enders C, et al. Involvement of intact HPV 16 E6/E7 expression in head and neck cancers with unaltered p53 status and perturbed pRb cell cycle control. Oncogene 2002;21:1510-7.

17. Reimers N, Kasper HU, Weissenborn SJ, et al. Combined analysis of HPV-DNA, p16 and EGFR expression to predict prognosis in oropharyngeal cancer. Int $J$ Cancer 2007;120:1731-8. 
18. Almadori G, Galli J, Cadoni G, et al. Human papillomavirus infection and cyclin D1 gene amplification in laryngeal squamous cell carcinoma: biologic function and clinical significance. Head Neck 2002;24:597-604.

19. Erber R, Klein W, Andl T, et al. Aberrant p21(CIP1/WAF1) protein accumulation in head and neck cancer. Int $J$ Cancer 1997;74:383-9.

20. Haraf DJ, Nodzenski E, Brachman D, et al. Human papilloma virus and p53 in head and neck cancer: clinical correlates and survival. Clin Cancer Res 1996;2:755-62.

21. Paz IB, Cook N, Odom-Maryon T, et al. Human papillomavirus (HPV) in head and neck cancer. Cancer 1997;79:595-604.

22. Ragin CC, Taioli E. Survival of squamous cell carcinoma of the head and neck in relation to human papillomavirus infection: review and meta-analysis. Int $\mathrm{J}$ Cancer 2007;121:1813-20.

23. Wenzel S, Sagowski C, Kehrl W, et al. The prognostic impact of metastatic pattern of lymph nodes in patients with oral and oropharyngeal squamous cell carcinomas. Eur Arch Otorhinolaryngol 2004;261:270-5.

24. al-Abdulwahed S, Kudryk W, al-Rajhi N, et al. Carcinoma of the tonsil: prognostic factors. J Otolaryngol 1996;26:196-9.

25. Friesland S, Fernberg JO, Lundell G, et al. Prognostic impact of complete remission after preoperative irradiation of tonsillar carcinoma: a retrospective analysis of the radiumhemmet data, 1980-1995. Int J Radiat Oncol Biol Phys 1999;45:1259-66.

26. Snijders PJ, Steenbergen RD, Top B, et al. Analysis of p53 status in tonsillar carcinomas associated with human papillomavirus. J Gen Virol 1994;75:2769-75.

27. Lindel K, Beer KT, Laissue J, et al. Human papillomavirus positive squamous cell carcinoma of the oropharynx: a radiosensitive subgroup of head and neck carcinoma. Cancer 2001;92:805-13.

27. Shanmugaratnam S. Histologic typing of tumors of the upper respiratory tract and ear. Geneva (Switserland): World Health Organization 1991.

28. Sgambato A, Migaldi M, Faraglia B, et al. Cyclin D1 expression in papillary superficial bladder cancer: its association with other cell cycle-associated proteins, cell proliferation and clinical outcome. Int J Cancer 2002;97:671-8.

30 Choi HR, Tucker SA, Huang Z, et al. Differential expressions of cyclin-dependent kinase inhibitors (p27 and p21) and their relation to p53 and Ki-67 in oral squamous tumorigenesis. Int J Oncol 2003;22:409-14.

31. Kwong RA, Kalish LH, Nguyen TV, et al. P14ARF protein expression is a predictor of both relapse and survival in squamous cell carcinoma of the anterior tongue. Clin Cancer Res 2005;11:4107-16.

32. Klaes R, Friedrich T, Spitkovsky D, et al U. Overexpression of p16(INK4A) as a specific marker for dysplastic and neoplastic epithelial cells of the cervix uteri. Int $J$ Cancer 2001;92:276-84.

33. Takes RP, Baatenburg de Jong RJ, et al. Expression of genetic markers in lymph node metastases compared with their primary tumours in head and neck cancer. Pathol 2001;194:298-302.

34. Kumar RV, Kadkol SS, Daniel R, et al. Human papillomavirus, p53 and Cyclin D1 expression in oropharyngeal carcinoma. Int J Oral Maxillofac Surg 2003;32:539-43.

35. Sjöström J, Blomqvist C, Heikkilä $P$, et al. Predictive value of p53, mdm-2, p21, and mib-1 for chemotherapy response in advanced breast cancer. Clin Cancer Res 2000;6:3103-10.

36. Korkmaz H, Du W, Yoo GH, et al. Prognostic significance of G1 cell-cycle inhibitors in early laryngeal cancer. Am J Otolaryngol 2005;26:77-82. 
37. Pich A, Chiusa L, Navone R. Prognostic relevance of cell proliferation in head and neck tumors. Ann Oncol 2004;15:1319-29.

38. Aebersold DM, Kollar A, Beer KT, et al. Involvement of the hepatocyte growth factor/scatter factor receptor cmet and of $\mathrm{Bcl}-\mathrm{xL}$ in the resistance of oropharyngeal cancer to ionizing radiation. Int J Cancer 2001;96:41-54.

39, Baltaziak M, Duraj E, Koda M, et al. Expression of Bcl-xL, Bax, and p53 in primary tumors and lymph node metastases in oral squamous cell carcinoma. Ann $N Y$ Acad Sci 2006;1090:18-25.

40. Lo Muzio L, Pannone G, Staibano S, et al. Survivin expression in oral squamous cell carcinoma. Br J Cancer 2003;89:2244-8.

41. Li F. Survivin study: what is the next wave? J Cell Physiol 2003;197:8-29.

42. Friedman M, Lim JW, Manders E, et al. Prognostic significance of Bcl-2 and p53 expression in advanced laryngeal squamous cell carcinoma. Head Neck 2001;23:280-5.

43. Li Y, Nichols MA, Shay JW, et al. Transcriptional repression of the D-type cyclindependent kinase inhibitor $\mathrm{p} 16$ by the retinoblastoma susceptibility gene product pRb. Cancer Res 1994;54:6078-82.

44. Kim YT, Zhao M. Aberrant cell cycle regulation in cervical carcinoma. Yonsei Med $J$ 2005;46:597-613.

45. Kamijo T, Zindy F, Roussel MF, et al. Tumor suppression at the mouse INK4a locus mediated by the alternative reading frame product p19ARF. Cell 1997;91: 649-59.

46. Krimpenfort P, Quon KC, Mooi WJ, et al. Loss of p16Ink4a confers susceptibility to metastatic melanoma in mice. Nature 2001;413:83-6.

47. Gillison ML, Koch WM, Capone RB, et al. Evidence for a causal association between human papillomavirus and a subset of head and neck cancers. J Natl Cancer Inst 2000;92:709-20.

48. el-Deiry WS, Tokino T, Velculescu VE, et al. WAF1, a potential mediator of p53 tumor suppression. Cell 1993;75:817-25.

49. Harper JW, Adami GR, Wei N, et al. The p21 cdk-interacting protein cip 1 is a potent inhibitor of G1 cyclin-dependent kinases. Cell 1993;75:805-16.

50. Milde-Langosch K, Riethdorf S, Kraus-Pöppinghaus A, et al. Expression of cyclindependent kinase inhibitors p16MTS1, p21WAF1, and p27KIP1 in HPV-positive and HPV-negative cervical adenocarcinomas. Virchows Arch 2001;439:55-61.

51. Michieli P, Chedid M, Lin D, et al. Induction of WAF1/CIP1 by a p53-independent pathway. Cancer Res 1994;54:3391-5.

52. el-Deiry WS, Harper JW, O'Connor PM, et al. WAF1/CIP1 is induced in p53mediated G1 arrest and apoptosis. Cancer Res 1994;54:1169-74.

53. Butz K, Shahabeddin L, Geisen C, et al. Functional p53 protein in human papillomavirus-positive cancer cells. Oncogene 1995;10:927-36.

54. Li W, Thompson CH, O'Brien CJ, et al. Human papillomavirus positivity predicts favourable outcome for squamous carcinoma of the tonsil. Int $J$ Cancer 2003;106:553-8.

55. Smeets SJ, Hesselink AT, Speel EJ, et al. A novel algorithm for reliable detection of human papillomavirus in paraffin embedded head and neck cancer specimen. Int J Cancer 2007;121:2465-72.

56. Franceschi S, Muñoz N, Snijders PJ. How strong and how wide is the link between HPV and oropharyngeal cancer? Lancet 2000;356:871-2. 
57. Goto M, Tsukamoto $\mathrm{T}$, Inada $\mathrm{K}$, et al. Loss of $\mathrm{p} 21 \mathrm{WAF} 1 / \mathrm{CIP} 1$ expression in invasive fronts of oral tongue squamous cell carcinomas is correlated with tumor progression and poor prognosis. Oncol Rep 2005;14:837-46.

58. Hirai $\mathrm{T}$, Kuwahara M, Yoshida K, et al. The prognostic significance of p53, p21 (Waf1/Cip1), and cyclin D1 protein expression in esophageal cancer patients. Anticancer Res 1999;19:4587-91.

59. Peschos D, Stefanou D, Vougiouklakis $T$, et al. Cell cycle proteins in laryngeal cancer: role in proliferation and prognosis. J Exp Clin Cancer Res 2005;24:431-7.

60. Mellin H, Dahlgren L, Munck-Wikland E, et al. Human papillomavirus type 16 is episomal and a high viral load may be correlated to better prognosis in tonsillar cancer. Int J Cancer 2002;102:152-8.

61. Sisk EA, Soltys SG, Zhu S, et al. Human papillomavirus and p53 mutational status as prognostic factors in head and neck carcinoma. Head Neck 2002;24:841-9.

62. Schwartz SR, Yueh B, McDougall JK, et al. Human papillomavirus infection and survival in oral squamous cell cancer: a population-based study. Otolaryngol Head Neck Surg 2001;125:1-9.

63. Chiba I, Shindoh M, Yasuda M, et al. Mutations in the p53 gene and human papillomavirus infection as significant prognostic factors in squamous cell carcinomas of the oral cavity. Oncogene 1996;12:1663-8.

64. Weinberger PM, Yu Z, Haffty BG, Kowalski D, et al. Molecular Classification identifies a subset of human papillomavirus-associated oropharyngeal cancers with favorable prognosis. J Clin Oncol 2006;24:736-47. 


\section{Chapter}

\section{GENETIC SIGNATURES OF HPV- RELATED AND UNRELATED OROPHARYNGEAL CARCINOMA AND THEIR PROGNOSTIC IMPLICATIONS}

Jens P Klussmann, Jeroen J Mooren, Martin Lehnen,

Sandra MH Claessen, Markus Stenner,

Christian U Huebbers, Soenke J Weissenborn, Inga Wedemeyer, Simon F Preuss, Jos Straatmans, Johannes J Manni, Anton HN Hopman, Ernst-Jan M Speel

Clinical Cancer Research 2009;15:1779-1786

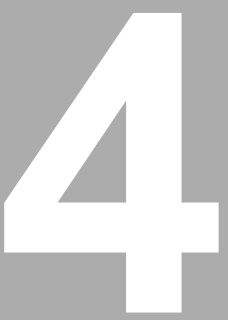




\section{Abstract}

\section{Purpose}

Patients with human papillomavirus (HPV)-containing oropharyngeal squamous cell carcinomas (OPSCC) have a better prognosis than patients with HPV-negative OPSCC. This may be attributed to different genetic pathways promoting cancer.

\section{Experimental design}

We used comparative genomic hybridization to identify critical genetic changes in 60 selected OPSCC, 28 of which were associated with HPV-16 as determined by HPV-specific PCR and fluorescence in situ hybridization analysis and positive $\mathrm{p} 16^{\text {INK4A }}$ immunostaining. Results were correlated with HPV status and clinical data from patients.

\section{Results}

Two thirds of OPSCC harbored gain at 3q26.3-qter irrespective of HPV status. In HPV-negative tumours this alteration was associated with advanced tumour stage $(p=0.013)$. In comparison with HPV-related OPSCC, the HPV-negative tumours harbored: a) a higher number of chromosomal alterations and amplifications $(p=0.03$ and 0.039 , respectively), b) significantly more losses at $3 p, 5 q, 9 p, 15 q$ and $18 q$ and gains/amplifications at 11q13 $(p=0.002,0.03,<0.001,0.02,0.004$ and 0.001 , respectively), and c) less often $16 q$ losses and $X p$ gains ( $p=0.02$ and 0.03 ). Survival analysis revealed a significantly better disease-free survival for HPV-related OPSCC $(p=0.02)$, whereas chromosome amplification was an unfavorable prognostic indicator for disease-free and overall survival ( $p=0.01$ and 0.05 , respectively). Interestingly, $16 q$ loss, predominantly identified in HPV-related OPSCC, was a strong indicator of favorable outcome (overall survival: $p=0.008$, disease-free survival $p=0.01$ ) and none of these patients had a tumour recurrence.

\section{Conclusions}

Genetic signatures of HPV-related and -unrelated OPSCC are different and most likely underlie differences in tumour development and progression, In addition, distinct chromosomal alterations have prognostic significance. 


\section{Introduction}

In the western world head and neck squamous cell carcinomas account for $\sim 5 \%$ of all cancers. Particularly the annual incidence of cancers developing in the oropharynx, oropharyngeal squamous cell carvinomas (OPSCC) is still increasing, whereas the incidence at other sites is declining. ${ }^{1,2}$ An estimated rate of $>35.000$ new cases of OPSCC are expected in the United States in 2008 , and $\sim 7.000$ patients are expected to die from the disease. ${ }^{3}$ Despite the implementation of multimodal treatment regimes in recent years, the prognosis of OPSCC has only slightly been improved. ${ }^{4,5}$ Identification of the molecular mechanisms underlying the carcinogenesis of OPSCC, therefore, seems crucial to enable the development of new therapeutic agents.

OPSCC from an interesting group of head and neck cancers to focus on, because in the past decades molecular and epidemiological studies have revealed that $25 \%$ to $50 \%$ of these tumours are associated with oncogenic human papillomavirus (HPV) ${ }^{6-8}$ High risk sexual behavior has particularly been related to the development of this group of OPSCC. ${ }^{9}$ The remaining group of OPSCC is predominantly associated with the risk factors tobacco smoking and alcohol consumption, also referred to as chemical/toxin-induced OPSCC. In contrast to the finding, that the majority of patients harboring HPV-DNAcontaining carcinomas present with an advanced stage of the disease, there is growing evidence that these patients have a favorable prognosis. ${ }^{10-13}$ In addition, differences in the expression of cell cycle and survival proteins, ${ }^{14-16}$ and TP53 gene mutation status ${ }^{17-19}$ have been identified comparing HPV-positive with HPV-negative OPSCC. Recently, our group was able to show that $\mathrm{p} 16^{\mathrm{INK} 4 \mathrm{~A}}$ (CDKN2A gene product) is highly expressed in HPV-related OPSCC $^{12,20,21}$ and is a reliable surrogate marker to identify these tumours. ${ }^{11}$ Therefore, $\mathrm{p} 16^{\mathrm{INK} 4 \mathrm{~A}}$ immunostaining and subsequent HPV-PCR have been recommended to detect HPV-related OPSCC. ${ }^{22}$ All together these findings lead to the hypothesis that at least two genetic routes underlie the development of OPSCC. ${ }^{23,24}$

The development of chemical/toxin-induced OPSCC seems to occur via accumulation of distinct (epi)genetic changes. Deletions at chromosomes $3 p$ and 9 p21 are already found in premalignant lesions, ${ }^{25,26}$ whereas further carcinogenesis is associated with losses at $4 q, 5 q, 7 q, 8 p, 13 q, 17 p, 18 q, 21 q$ and $22 q$ and gains at $1 q, 2 q, 3 q 26,5 p, 7 p, 8 q, 9 q, 11 q 13$ and $20 q .{ }^{27-29}$ The target genes for some alterations are known, such as the CDKN2A gene at 9p21, TP53 at 17p13, and CCND1 at 11q13. Gains at 3q, 11q and 12q and losses at $5 q, 6 q, 8 p, 21 q$ and $22 q$ have been associated with poor prognosis. $^{30,31}$

In contrast, HPV-related cancers harbor gains of $1 \mathrm{q}$ in early stages of tumour development and gains of $3 q, 5 p$ and $8 q$ and losses of $2 q, 3 p, 4 q, 11 q$ and $19 p$ 
later in tumour progression. ${ }^{32-34}$ Gain of $3 q$ has been correlated to integration of HPV-DNA into the cellular genome and progression to cancer in uterine cervical premalignant lesions. ${ }^{35}$ Therefore, it can be speculated that the genetic signature of chemical/toxin-induced and HPV-related OPSCC also differ with respect to quantity and chromosomal location of genetic changes.

In this study, we have analyzed a series of 60 OPSCC, of which the HPV status and the clinical follow-up were available, for DNA copy number changes by genome-wide comparative genomic hybridization $(\mathrm{CGH})$. Results were correlated with clinico-pathologic characteristics, smoking and alcohol intake and disease outcome.

\section{Materials and methods}

\section{Subjects and material}

For this study we selected from previous studies 29 HPV16-DNA positive OPSCC and 31 HPV-negative tumours from patients treated at the Department of Oto-Rhino-Laryngology, Head and Neck Surgery of the University of Cologne from 1997 to December 2005 on basis of the following criteria: a) availability of sufficient fresh-frozen tumour tissue with $\geq 70 \%$ tumour cells and high quality and enough tumour DNA, b) availability of clinical follow-up for $\geq 2$ $y$, and c) assessment of the presence or absence of HPV sequences. HPV DNA was detected with a highly sensitive group-specific nested PCR with degenerate primers $\mathrm{A} 5 / \mathrm{A} 10$ and $\mathrm{A} 6 / \mathrm{A} 8 .^{36} \mathrm{HPV}$ typing was done as described previously. ${ }^{8}$ A subset of 20 HPV16-positive cases was confirmed by fluorescence in situ hybridization using HPV16-specific DNA probes as previously described (Figure $4.1 \mathrm{~A}) .{ }^{12,17}$

Patient ages ranged from 43 to 79 y (median, $60 \mathrm{y}$ ). Forty-seven patients were males $(78 \%)$ and 13 were females $(22 \%)$. Written, informed consent was obtained from all patients. Tumour staging was assessed according to the 2002 American Joint Committee on Cancer staging criteria. ${ }^{37}$ Three percent of the patients presented at stage I, $12 \%$ at stage II, $15 \%$ at stage III, $53 \%$ at stage $\mathrm{IVa}$, and $12 \%$ at stage IVb. Three patients (5\%) had distant metastases (stage IVc) at the time of diagnosis. Histological grading was performed in a blind manner following the WHO criteria for squamous cell carcinomas of the oral mucosa. $^{38}$ Patients were treated with multimodal treatment regime as previously reported. ${ }^{5}$ Stratification of tumour stage, patient's age and treatment within HPV-related and -unrelated tumours revealed equal distribution and no significant differences. To include other major risk factors for OPSCC in our analysis we evaluated history of tobacco smoking and alcohol consumption from chart reviews. Total cumulative tobacco exposure was expressed in packyears, where one pack-year is equivalent to smoking one pack of cigarettes a 
day for one year. To dichotomise this parameter patients were divided into the categories smoker and non-smoker having history of more or less than 1 packyear in the last 10 years. Alcohol exposure was defined as the average number of drinks per week. Follow-up data were collected at periodic visits in 4- to 6-months intervals at our outpatients department.

A.

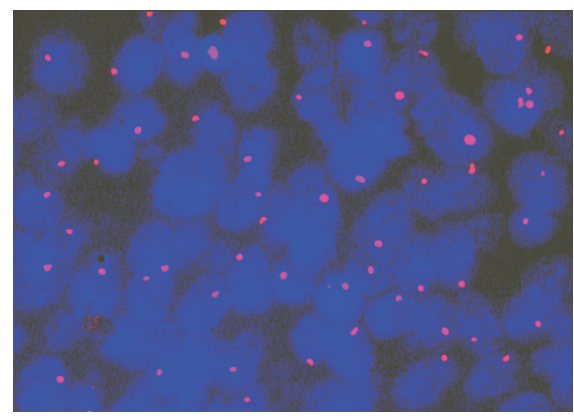

C.

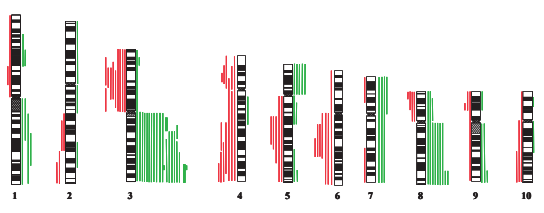

B.

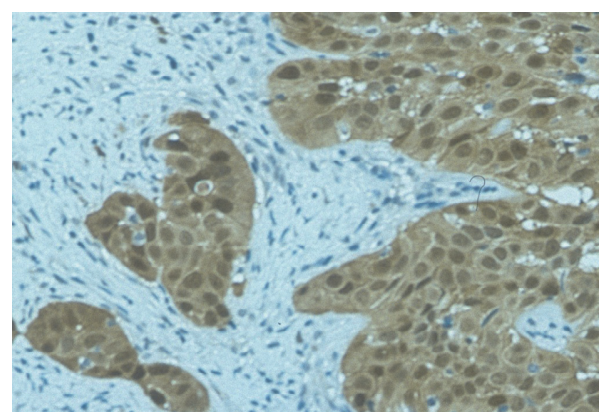

D.
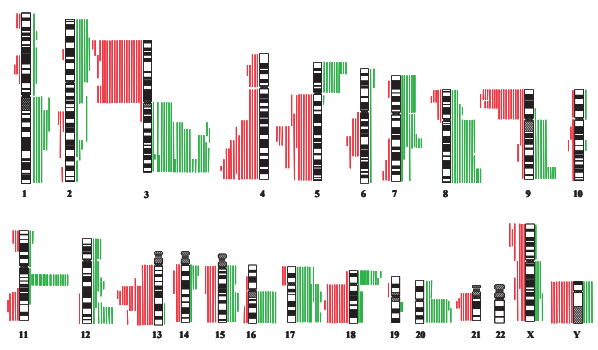

Figure 4.1 Representative examples of FISH analysis showing one HPV 16-specific punctate signal per nucleus indicating viral integration in the cellular genome $(\mathbf{A})$ and $\mathrm{p} 16^{\text {INK4A }}$ immunostaining (B) with strong $\mathrm{p} 16^{\mathrm{INK} 4 \mathrm{~A}}$ overexpression on paraffin-embedded tissue sections of OPSCC. DNA copy number changes in HPV-related (C) and unrelated (D) OPSCC as identified by $\mathrm{CGH}$. Gains are shown in green on the right side of the chromosome ideograms. Amplifications are indicated by bold lines. Losses are shown on the left side of the ideograms in red.

\section{Immunohistochemical staining}

To confirm PCR-based HPV status p16 ${ }^{\text {INK4A }}$ immunohistochemical detection of expression was performed as described previously. ${ }^{18}$ Two- to three-micrometer sections of formalin-fixed, paraffin-embedded biopsy samples were processed by the avidin-biotin-peroxidase method (Chem Mate Detection kit; Dako Cytomation) using a primary antibody against $\mathrm{p} 16^{\mathrm{INK} 4 \mathrm{~A}}$ (Ab-4, clone 16P04 Neo Markers). HPV16-positive cervical carcinoma specimens were used as positive control. Strong and diffuse nuclear as well as cytoplasmic staining in $>60 \%$ of 
the tumour cells was regarded as overexpression. Only cases with positive HPV-PCR and p16 overexpression in their tumours were regarded as HPV-related OPSCC (see below).

\section{CGH}

$\mathrm{CGH}$ was done with DNA isolated from tumour samples as previously described. ${ }^{39}$ Briefly, $2 \mu \mathrm{g}$ tumour DNA was labeled with Spectrum GreendUTPs (Abbott Molecular) by nick translation (BioNick labeling kit, Life Technologies). Spectrum Red-labeled normal and sex-matched reference DNA (Life technologies) was used for cohybridization. The hybridization mixture consisted of $800 \mathrm{ng}$ Spectrum Green-labeled tumour DNA, $800 \mathrm{ng}$ of Spectrum-Red labeled reference DNA and $10 \mu \mathrm{g}$ of human Cot-1 DNA (Life Technologies) dissolved in $12 \mu \mathrm{l}$ of hybridization buffer $(50 \%$ formamide, 2xSSC, $10 \%$ dextran sulfate, $\mathrm{pH} 7.0$ ). Hybridization was carried out for $3 \mathrm{~d}$ at $37^{\circ} \mathrm{C}$ to denatured $\left(5 \mathrm{~min}\right.$ at $75^{\circ} \mathrm{C}$ in $2 \times \mathrm{SSC} \mathrm{pH} 7.0$, followed by $5 \mathrm{~min}$ in $70 \%$ formamide/2xSSC, pH 7.0) normal male human metaphase spreads (Abbott Molecular). Slides were washed two times at $45^{\circ} \mathrm{C}$ for $5 \mathrm{~min}$ in $50 \%$ formamide/2xSSC, $\mathrm{pH} 7.0$, followed by dehydration in an ethanol series. The chromosomes were counterstained with $0.2 \mu \mathrm{g} \mathrm{4,6-diamidino-2-phenylindole}$ per $\mu \mathrm{l}$ Vectashield (Vector laboratories) for identification.

Digital images were collected from at least ten metaphases using the Metasystems Image Pro System black and white CCD camera (Altlussheim) mounted on top of a Leica DMRE fluorescence microscope, equipped with 4'-6Diamidino-2-phenylindole, Spectrum Green, and Spectrum Red filter sets. The software Metasystems ISIS 4.4.25 program was used to calculate average green-to-red ratio profiles for each chromosome. At least 10 observations per autosome and 5 observations per sex chromosome were included in each analysis. Gains and losses of DNA sequences were defined as chromosomal regions where the mean green-to-red fluorescence ratio was $>1.20$ and $<0.80$, respectively. Overrepresentations were considered amplifications when the fluorescence ratio values in a subregion of a chromosomal arm exceeded 1.5. In negative control hybridizations, the mean green-to-red ratio occasionally exceeded the fixed 1.2 cutoff level at the following chromosomal regions: 1p32-pter, 16p, 19, and 22. Gains of these G-C-rich regions were therefore excluded from all analyses.

\section{Statistical analysis}

Contingency table analysis was used to analyze the relationship between $\mathrm{HPV} / \mathrm{p} 16^{\mathrm{INK} 4 \mathrm{~A}}$-status and genomic alterations with the SPSS Base System, version 14.0 (SPSS). Student's $t$ test and ANOVA were applied to compare the number of genomic alterations in different groups. A significance level of $p \leq 0.05$ was chosen. Multivariate logistic regression was done to assess the 
association between HPV/p16 $16^{\text {INK4A }}$ status and genomic alterations while controlling for clinicopathologic factors and potential confounders.

Disease-free and overall survival rates were estimated using the Kaplan-Meier algorithm for incomplete observations. Three patients were excluded from survival analysis due to having stage IVc disease. The overall survival time was defined as the interval between the date of diagnosis and the last date when the patient was known to be alive (censored) or date of death for any reason (uncensored). The disease-free survival was measured as the period of time between the date of diagnosis and the date of the last follow-up examination, where the patient was disease-free (censored), or the date of first recurrence independently if it was a local, regional, or distant recurrence (uncensored). The log rank test was used to test for differences between subgroups. All $p$-values were considered statistically significant if $=0.05$ in two-sided tests.

\section{Results}

\section{Clinico-pathological data and $\mathrm{p} 16^{\mathrm{INK} 4 \mathrm{~A}}$ expression}

To further determine HPV-association $\mathrm{p} 16^{\mathrm{INK} 4 \mathrm{~A}}$ immunostaining was done on paraffin-embedded tissue sections of 57 OPSCC, of which $33(55 \%)$ were positive (Figure 4.1B). As expected there was a highly significant correlation of HPV-DNA detection by PCR and $p 16^{\text {INK4A }}$ expression $(p<0.001)$. Twenty-eight $(97 \%)$ of the HPV-positive tumours showed strong $\mathrm{p} 16^{\text {INK4A }}$ expression and these HPV/p16 ${ }^{\text {INK4A }}$ positive tumours were classified as HPV-related tumours for further analysis. The remaining 32 cases were summarized as HPV-unrelated. There was no significant difference of staging between both groups, but there was a significant association of the HPV-related cancers with poorer differentiation of the tumour $(p=0.05$, Table 4.1). HPV-related tumours were more likely located in the tonsils or in the base of the tongue compared to other parts of the oropharynx $(p<0.001$, Table 4.1). Evaluation of the risk factors smoking and alcohol used as categorized variables showed a significant lower exposure for nicotine and alcohol for patients with HPV-related OPSCC ( $p=0.006$ and $p<0.001$, respectively; Table 4.1$)$. 
Table 4.1 Clinical and genomic differences between HPV-unrelated and related OPSCC.

\begin{tabular}{|c|c|c|c|c|c|c|}
\hline Parameter & $\begin{array}{l}\text { Total } \\
\mathrm{n}(\%) \\
\end{array}$ & $\begin{array}{c}\text { HPV-unrelated } \\
\mathrm{n}(\%)\end{array}$ & $\begin{array}{c}\text { HPV-related } \\
\mathrm{n}(\%)\end{array}$ & $P^{*}$ & $\mathrm{P} \dagger$ & $P \ddagger$ \\
\hline \multicolumn{7}{|l|}{ Clinical data } \\
\hline Number of patients & $60(100)$ & $32(53)$ & $28(47)$ & & & \\
\hline alcohol use§ & $24(40)$ & $20(63)$ & $4(14)$ & $<0.001$ & N.D. & N.D. \\
\hline Tobacco usell & $48(80)$ & $30(94)$ & $18(64)$ & 0.006 & N.D. & N.D. \\
\hline Tumour grading & $30(51)$ & $12(39)$ & $18(64)$ & 0.05 & N.D. & N.D. \\
\hline Tumour location** & $46(77)$ & $19(59)$ & $27(96)$ & $<0.001$ & N.D. & N.D. \\
\hline \multicolumn{7}{|l|}{ Genetic alterations } \\
\hline $\begin{array}{l}\text { Gresence of at least one } \\
\text { amplification }\end{array}$ & $16(27)$ & $12(38)$ & $4(14)$ & 0.04 & 0.03 & N.S. \\
\hline \multicolumn{7}{|l|}{ Gains or amplifications } \\
\hline $11 q 13$ & $16(27)$ & $14(44)$ & $2(7)$ & 0.001 & 0.003 & N.S. \\
\hline$X p$ & $7(12)$ & $1(3)$ & $6(21)$ & 0.03 & N.S. & N.S. \\
\hline \multicolumn{7}{|l|}{ Losses } \\
\hline $3 p$ & $34(57)$ & $24(75)$ & $10(36)$ & 0.002 & 0.008 & 0.02 \\
\hline $5 q$ & $19(32)$ & $14(44)$ & $5(18)$ & 0.03 & 0.03 & N.S. \\
\hline $9 p$ & $23(38)$ & $20(63)$ & $3(11)$ & $<0.001$ & $<0.001$ & 0.001 \\
\hline 11q14-qter & $16(27)$ & $5(16)$ & $11(39)$ & 0.04 & N.S. & N.S. \\
\hline $15 q$ & $5(8)$ & $5(16)$ & $0(0)$ & 0.02 & N.S. & N.S. \\
\hline $16 q$ & $10(17)$ & $2(6)$ & $8(29)$ & 0.02 & 0.03 & 0.05 \\
\hline $18 q$ & $11(18)$ & $10(31)$ & $1(4)$ & 0.004 & 0.02 & 0.05 \\
\hline
\end{tabular}

N.D., not done; N.S., not significant. * Univariate analysis; † Multiple regression adjusting for age, gender, and TNM-stage; $\ddagger$ Multiple regression adjusting for age, gender, TNM-stage, alcohol and tobacco use; § Alcohol exposure includes beer, wine, and liquor. Alcohol equivalents (drinks) were defined as one 12-ounce can/bottle of beer $=$ one 4-ounce glass of wine $=$ one $1 \frac{1}{2}$ ounce shot of liquor $\sim 12 \mathrm{~g}$ alcohol. Variable was categorized $>5$ drinks per week; II $>1$ pack-year in the last 10 years; II Tumour grading $>2$; ${ }^{*}$ Tumour located in tonsils or base of tongue compared to other parts of the oropharynx.

\section{CGH analysis}

The CGH results are presented in Figure 4.1C and 4.1D and Table 4.1. The total number of chromosomal aberrations per tumour was significantly lower in the HPV-related $(8.9 \pm 4.9)$ than in the HPV-unrelated group (12.1 $\pm 5.9 ; p=0.03)$, as was also observed for amplifications ( $14 \%$ vs. $38 \%, p=0.039)$. The HPV-unrelated tumours particularly harbored amplifications at $11 q 13$ and $18 p$, whereas amplifications at chromosome $3 q$ were detected in both groups (3q26.3-qter as smallest region of involvement). Gain of $3 q$ was the most frequent chromosomal alteration in OPSCC $(72 \%)$ independent of HPV status and was significantly associated with advanced $\mathrm{T}$ - and tumour stage in the total group (T1/T2 vs. T3/T4, $p=0.042 ; \quad I / I I$ vs. III/IV; $p=0.035$ ) and in the HPV-unrelated group of tumours (T1/T2 vs. T3/T4, $p=0.028$; I/II vs. III/IV; $\mathrm{p}=0.013)$.

Losses of $3 p, 4 q, 9 p$ and $13 q$ and gains of $3 q, 8 q$ and $17 q$ were found in $>33 \%$ of all OSCC. The most frequent genetic changes in $>30 \% \mathrm{HPV}$-unrelated cancers were losses at 3p, 4q, 5q, 9p, 13q, 18q and $Y$ and gains at 3q, 8q, 
11q13, 12q, 17q and 20q. In the HPV-related group losses at 3p, 4q, 11q14qter, $13 q$ and gains at $3 q, 8 q, 17 q$ and $20 q$ were identified in $>30 \%$ of tumours. Significant differences in the occurrence of chromosomal changes between $\mathrm{HPV} / \mathrm{p} 16^{\text {INK4A }}$-positive and -negative tumours were observed for gains at $11 \mathrm{q} 13$ and $X p$ and for losses at 3p, 5q, 9p, 11q14-qter, 15q, 16q, and 18q (Table 4.1). To determine possible confounders we analysed the DNA copy number changes comparing HPV-related and HPV-unrelated OPSCC while correcting for tumour stage, age and gender (model 1) and for tumour stage, age, gender, tobacco and alcohol consumption (model 2) by using multivariate logisticregression. In model 1 differences remained significant for most chromosomal aberrations (Table 4.1). Adjusting in addition for tobacco and alcohol use revealed still significant differences for $3 p, 9 p$ and $18 q$ loss (Table 4.1) but excluded $11 \mathrm{q} 13$ gain as a discriminating genetic alteration because it strongly correlated with exposure to these carcinogens (data not shown).

\section{Survival analysis}

The median follow up time was 27.5 months with a maximum of 111 months. Tumour relapse developed in $38 \%$ of study population and $38 \%$ of the patients died during observation time. The mean disease-free survival time after first diagnosis was $31.3 \pm 3.5$ months and the mean overall survival time was 37.0 \pm 3.8 months. HPV-related OPSCC showed a significantly better 5-year disease-free survival rate compared to HPV-unrelated OPSCC ( $71 \%$ vs. $46 \%$; $p=0.02$, Table 4.2, Figure 4.2A). Overall survival did not significantly differ between both OPSCC groups (Figure 4.2B). Using HPV-DNA detection by PCR for stratification yielded similar results (data not shown).

To determine the impact of genetic changes on prognosis in OPSCC patients all chromosomal alterations were used for stratification in Kaplan-Meier analysis. Chromosome amplification independent from its location was a significant predictor for a decreased 5 -year disease-free and overall survival in all patients ( $p=0.01$ vs. $p=0.05$; Table 4.2 ; Figure $4.2 \mathrm{C}$ and $4.2 \mathrm{D}$ ) and within the HPV-related cancers ( $p=0.03$ vs. $p=0.04$ ). Detection of a $11 q 13$ amplification was an indicator for unfavorable overall survival $(29 \%$ vs. $62 \%$; $p=0.02$; Table 4.2), which was found with one exception in HPV-unrelated cancers (Figure 4.1C and 4.1D).

Patients with $16 q$ loss in their tumour showed a strongly improved 5-year disease-free and overall survival $(p=0.008$ and $p=0.01$, respectively; Figure 4.2E and 4.2F), which was also significant in HPV-related cancers ( $p=0.05$ and $p=0.04$ ). Interestingly, also $9 p$ loss proved to be an indicator for favorable prognosis in this group, despite the small number of tumours exhibiting this alteration ( $p=0.04$ and $p<0.0015$ for 5 -year disease-free and overall survival, respectively). Within the group of HPV-unrelated cancers $3 p$ loss was an indicator for an improved 5 -year disease-free survival rate $(55 \%$ vs. $19 \%$; 
$\mathrm{p}=0.04$ ). In addition, patients with an OPSCC containing $11 \mathrm{p}$ loss or Xp gain and non-smoker tended to show a favorable prognosis, which however did not reach statistical significance (data not shown).

Table 4.2 Univariate 5-year overall and disease-free survival analysis stratified for HPV-relation and chromosomal parameters in 60 OPSCC patients.

\begin{tabular}{|c|c|c|c|c|c|c|}
\hline Parameter & $\begin{array}{c}\text { Disease-free } \\
\text { survival (DFS) }\end{array}$ & $\begin{array}{c}\text { Mean DFS in } \\
\text { months } \\
(95 \% \mathrm{Cl})\end{array}$ & $P$ & $\begin{array}{c}\text { Overall } \\
\text { survival } \\
\text { (OS) }\end{array}$ & $\begin{array}{c}\text { Mean OS in } \\
\text { months } \\
(95 \% \mathrm{Cl})\end{array}$ & $P$ \\
\hline HPV-related & $71 \%$ & $63(52-75)$ & & $65 \%$ & $61(49-73)$ & \\
\hline HPV-unrelated & $46 \%$ & $53(34-72)$ & 0.02 & $51 \%$ & $63(46-81)$ & N.S. \\
\hline \multicolumn{7}{|l|}{ Amplifications } \\
\hline Yes & $34 \%$ & $22(13-30)$ & & $40 \%$ & $43(25-62)$ & \\
\hline No & $66 \%$ & $74(59-90)$ & 0.01 & $64 \%$ & 78 (64-92) & 0.05 \\
\hline \multicolumn{7}{|c|}{ Amplification at $11 q 13$} \\
\hline Yes & $47 \%$ & $21(11-32)$ & & $29 \%$ & $19(10-29)$ & \\
\hline No & $60 \%$ & $69(55-84)$ & N.S. & $62 \%$ & 76 (62-89) & 0.02 \\
\hline \multicolumn{7}{|l|}{$16 q$-loss } \\
\hline Yes & $100 \%$ & & & $100 \%$ & & \\
\hline No & $48 \%$ & $57(42-72)$ & 0.008 & $49 \%$ & $63(49-77)$ & 0.01 \\
\hline \multicolumn{7}{|c|}{$\begin{array}{l}\text { 16q-loss } \\
\text { (only HPV-related cases) }\end{array}$} \\
\hline Yes & $100 \%$ & & & $100 \%$ & & \\
\hline No & $59 \%$ & $51(37-65)$ & 0.05 & $51 \%$ & $49(35-62)$ & 0.04 \\
\hline \multicolumn{7}{|c|}{$\begin{array}{l}\text { 9p-loss } \\
\text { (only HPV-related cases) }\end{array}$} \\
\hline Yes & $74 \%$ & $65(54-77)$ & & $70 \%$ & $65(53-77)$ & \\
\hline No & $50 \%$ & $13(8-17)$ & 0.04 & $50 \%$ & $14(10-18)$ & $<0.001$ \\
\hline \multicolumn{7}{|c|}{$\begin{array}{l}\text { 3p-loss } \\
\text { (only HPV-unrelated cases) }\end{array}$} \\
\hline Yes & $55 \%$ & $66(44-88)$ & & $53 \%$ & 65 (45-88) & \\
\hline No & $19 \%$ & $22(4-39)$ & 0.05 & $47 \%$ & $42(19-66)$ & N.S. \\
\hline
\end{tabular}

$95 \% \mathrm{Cl}=95 \%$ confidence interval. 
A.

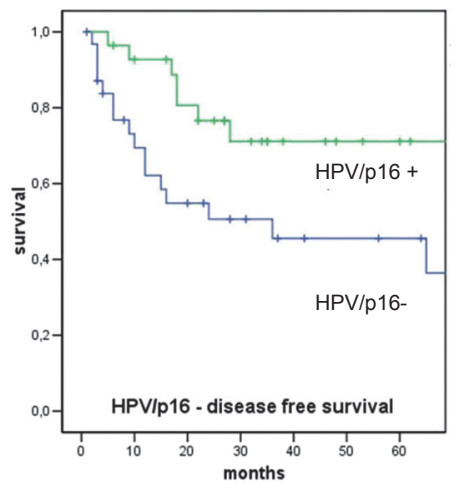

C.

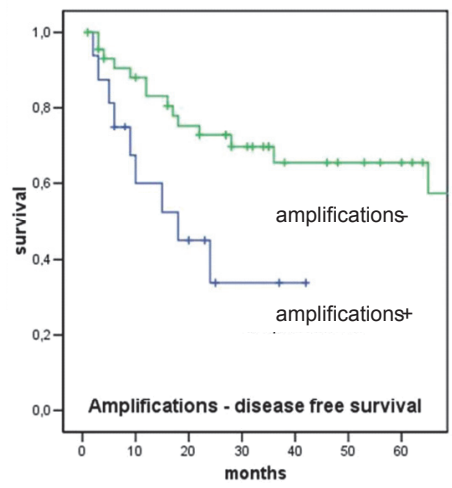

E.

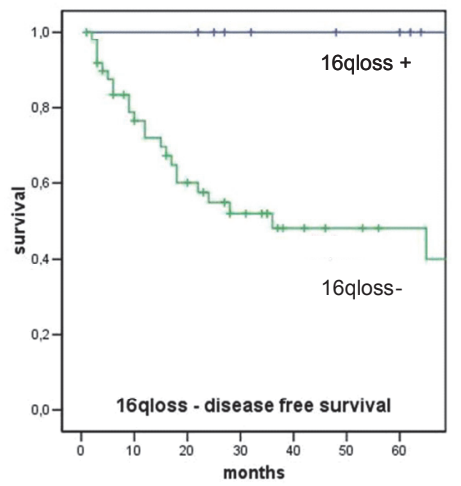

B.

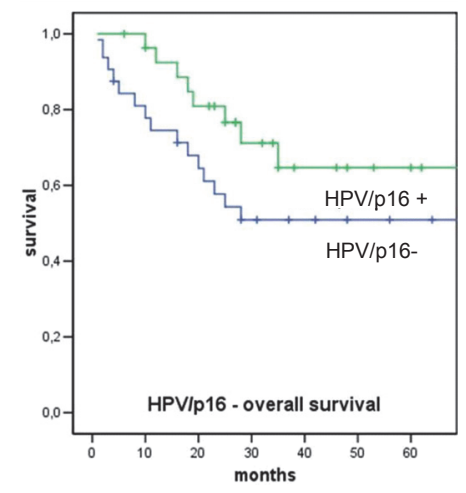

D.

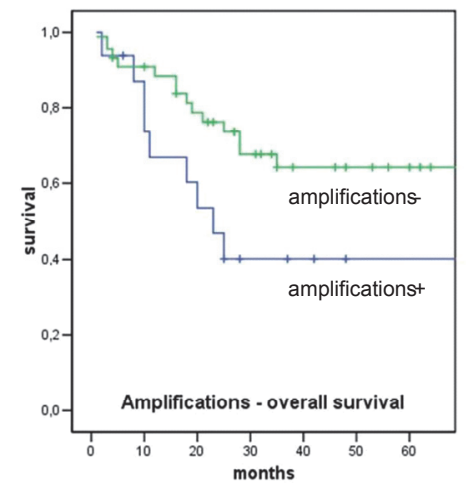

F.

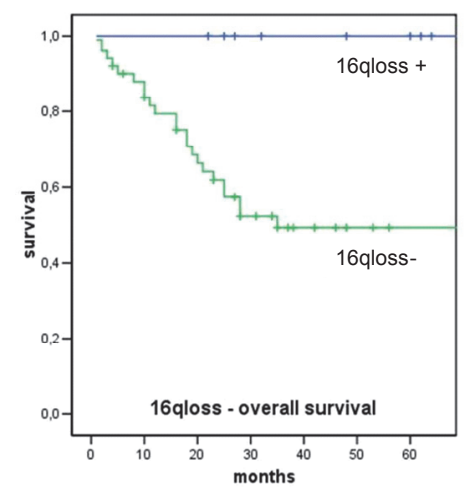

Figure 4.2 Univariate survival analysis stratified for the following groups: HPV-related and unrelated $\operatorname{OPSCC}(\mathbf{A}, \mathbf{B})$, amplification in the tumour (C, D, ) and detection of $16 \mathrm{q}$ loss $(\mathbf{E}, \mathbf{F})$. Disease-free survival $(\mathbf{A}, \mathbf{C}$ and $\mathbf{E})$ and overall survival $(\mathbf{B}, \mathbf{D}$ and $\mathbf{F})$ curves based on the Kaplan-Meier method are shown. 


\section{Discussion}

Head and neck cancers are a heterogeneous group of malignancies in terms of etiology, biological behavior and prognosis. ${ }^{40}$ Tobacco and alcohol consumption are the main risk factors for these cancers and models of sequential accumulation of (epi)genetic changes have been introduced. ${ }^{41}$ There is also molecular evidence that a significant proportion of these cancers are associated with oncogenic HPV, particularly those originating from the oropharynx. Our study represents the most comprehensive assessment of chromosomal alterations in relation to HPV status and prognosis in tumours detected in this anatomical site. HPV-related cancers were defined as being HPV-DNA-positive using PCR and $\mathrm{p} 16^{\mathrm{INK} 4 \mathrm{~A}}$ immunostaining, as recommended recently. ${ }^{22}$

We found that per tumour the total number of chromosomal alterations as well as amplifications was significantly lower in the HPV-related than in the HPVunrelated OPSCC. This finding is in accordance with previous molecular genetic reports ${ }^{42,43}$ and with the assumption that due to the inactivation of the tumour suppressor proteins p53 and pRb by the viral E6 and E7 oncoproteins, respectively, the number of required genetic alterations for a malignant phenotype is lower in HPV-driven tumourigenesis. Moreover, a recent study using uterine cervical cancer specimens has pointed out that a substantial number of lesions show integrated HPV DNA in (near)diploid rather than aneuploid cells. ${ }^{44}$ Preliminary data on a series of 20 tumours suggests that this is also the case in most HPV-related OPSCC when compared with HPVunrelated cases. ${ }^{7}$

Although in a previous $\mathrm{CGH}$-study on 25 tonsillar carcinomas $3 q$ gain was associated with HPV presence, ${ }^{43}$ in our series of 60 tumours and a recently reported series of 24 tumours $^{42}$ this alteration was found to be the most frequent in both HPV-related and -unrelated tumours. Gains in $3 q$ copy number are frequently found in squamous cell carcinomas, including those originating from the head and neck, lung, vulva and uterine cervical mucosa. $^{27,32,44-46}$ This alteration has been implicated as a key event in the progression from severe dysplasia to invasive cancer in lung and uterine cervical tumours. ${ }^{32,46}$ For OPSCC, however, it remains to be determined if $3 q$ gain is a marker for progression. ${ }^{12}$ Our data indicate that $3 q$ gain is a late event in HPV-unrelated OPSCC, because $3 q$ gain did correlate with advanced T- and tumour stage in this subgroup. The regions of copy number gain ranged in size from the whole $3 q$ arm to the smallest region of involvement at 3q26.3-qter. Of the numerous genes on chromosome $3 q$ that have been implicated in cancer ATR at $3 \mathrm{q} 23$ is a candidate. ATR has been shown to induce loss of differentiation, aneuploidy and to eliminate radiation-induced $G_{1}$ arrest upon duplication in rhabdomyosarcomas, ${ }^{47}$ features also recognized in OPSCC. 
Most reported candidate genes, however, reside in the 3q26.3-qter region, which we found amplified in six tumours, and is also frequently amplified in lung tumours. ${ }^{46}$ These include, among others, PIK3CA, TP63, TERC, DCUN1D1, $\angle A M P 3$ and RPL35A. ${ }^{44,46,48-51}$ More studies are needed to indicate which of these genes are pivotal in HPV-related and -unrelated OPSCC pathogenesis.

We noticed that the most significant genetic differences between HPV-related and HPV-unrelated OPSCC included 11q13 gains and 3p, 9p and 18q losses, which occurred more frequently in the latter group. Increased 11q13 copy numbers were identified in $44 \%$ of the HPV-unrelated OPSCC, a frequency which is often detected in chemical/toxin-induced head and neck cancer. ${ }^{28,31,42,52,53}$ In our study population $64 \%$ of the patients with HPV-related cancers were smokers, which could confound our results, but only $6(21 \%)$ of these patients were heavy smokers with the lifetime history of more than 24 pack-years and none of them had a 11q13 gain/amplification in their tumour. In contrast, in the HPV-unrelated OPSCC we did find a significant association between $11 \mathrm{q} 13$ gain and tobacco and alcohol consumption. The best candidate genes in the gained $11 \mathrm{q} 13$ region, whose products have been shown to be overexpressed, include CCND1, CTTN and FADD resulting in deregulation of cell cycle control and migration. Because cyclin D1 upregulation is ineffective in inactivate $\mathrm{pRb}$ in virus-driven tumourigenesis, which uses $E 7$ for this purpose, $11 q 13$ amplification is seldom observed in HPV-related OPSCC. Some studies suggest that $11 \mathrm{q} 13$ amplification is caused by breakage-fusion-bridge cycles initiated at the chromosomal fragile site $F R A 11 F^{54}$ and is often associated with loss of material of distal $11 \mathrm{q} .{ }^{55}$ Fragile sites have also been frequently observed as sites for HPV-DNA integration ${ }^{56}$ resulting in alterations of genomic structure. For example, in cervical cancer a high percentage of 11q22 loss has been reported. ${ }^{57,58}$ In our study we also found $11 \mathrm{q}$ losses more frequent in the HPV-related OPSCC and most were distal to $11 \mathrm{q} 22$. This difference could not be detected in either of two previous $\mathrm{CGH}$-studies. ${ }^{42,43}$ Several DNA repair genes, such as ATM and CHEK1, are located on chromosome 11q22-q24 and gene inactivation might underlie the genomic instability observed in HPV-related cancers.

Deletions at $3 p$ and $9 p$ have been observed in more than two thirds of head and neck squamous cell carcinomas ${ }^{25,28}$ and were in our study predominantly detected in the HPV-unrelated OPSCC. Therefore the suggestion that in HPV-negative OPSCC $3 p$ and $9 p$ loss is sporadically detected by $\mathrm{CGH}$, as stated previously, ${ }^{43}$ cannot be confirmed. Among the target tumour suppressor genes for these loci are FHIT at 3p14.3 and CDKN2A at 9p21. FHIT is located at the frequently altered fragile site $F R A 3 B$ and its inactivation has been linked to deregulation of cell signaling pathways, including nuclear factor $-\mathrm{k}-\beta$, AKT-Survivin and Src. The observation that $3 p$ loss is also detected in a subgroup of HPV-related OPSCC might relate to the fact that FRA3B is an 
integration hot spot for HPV. ${ }^{33}$ Inactivation of $\mathrm{p} 16^{\mathrm{INK} 4 \mathrm{~A}}$ is an early and frequent event in head and neck squamous cell carcinoma leading to the disruption of $\mathrm{pRb}$ cell cycle control. In our study 9p loss coincided with 11q13 gain/amplification $(p=0.003)$ underscoring deregulation of this pathway in chemical/toxin-induced OPSCC. In the HPV-related tumours HPV-E7 interferes with this pathway and as a consequence, $\mathrm{p} 16^{\mathrm{INK} 4 \mathrm{~A}}$ inactivation is not required and overexpression of the protein is usually detected.

In accordance with previous reports by us and others, ${ }^{11-13.20}$ HPV-related OPSCC showed a favorable prognosis. Interestingly, different genetic changes proved to be significant indicators of clinical outcome, such as chromosome amplification at $3 q, 11 q 13$ and $18 p$ predictive for unfavorable and $16 q$ deletions predictive for favorable patient survival. The latter finding has also been reported for breast and prostate cancer. ${ }^{59,60}$ Although it is unlikely that $\mathrm{E}$-cadherin inactivation is related to $16 \mathrm{q}$ deletion, because of its correlation with poor prognosis, ${ }^{61}$ our finding might be linked to the common fragile site FRA16D, located at $16 \mathrm{q} 23.2$ and containing the WWOX gene. ${ }^{62}$ The relatively high occurrence of $16 \mathrm{q}$ loss in HPV-positive tumours suggests the use of FRA16D as a HPV integration site that, as described above, might lead to extended loss of 16q DNA. In our study population we also noticed a strong correlation between a worse disease-free survival and a) $3 p$ loss in HPV-unrelated OPSCC, and b) $9 p$ loss in HPV-related tumours. Although the number of tumours harboring these deletions in the different subsets was small, both alterations have been associated with an increased risk for malignancy in head and neck precursor lesions. ${ }^{25}$ Future studies are needed to validate these findings in larger series of OPSCC in relation to HPV.

In conclusion, we have identified specific DNA copy number changes that are associated with HPV- or chemically-induced OPSCC, and with prognosis. 


\section{References}

1. Frisch $M$, Hjalgrim $H$, Jaeger $A B$, Biggar RJ. Changing patterns of tonsillar squamous cell carcinoma in the United States. Cancer Causes Control 2000;11:489-95.

2. Shiboski $\mathrm{CH}$, Schmidt BL, Jordan RC. Tongue and tonsil carcinoma: increasing trends in the U.S. population ages 20-44 years. Cancer 2005;103:1843-9.

3. Jemal A, Siegel R, Ward E, Hao Y, Xu J, Murray T, et al. Cancer statistics, 2008. CA Cancer J Clin 2008;58:71-96.

4. Carvalho AL, Nishimoto IN, Califano JA, Kowalski LP. Trends in incidence and prognosis for head and neck cancer in the United States: a site-specific analysis of the SEER database. Int J Cancer 2005;114:806-16.

5. Preuss SF, Dinh V, Klussmann JP, Semrau R, Mueller RP, Guntinas-Lichius O. Outcome of multimodal treatment for oropharyngeal carcinoma: a single institution experience. Oral Oncol 2007;43:402-7.

6. Syrjanen S. Human papillomaviruses in head and neck carcinomas. N Engl J Med 2007;356:1993-5.

7. Kreimer AR, Clifford GM, Boyle P, Franceschi S. Human papillomavirus types in head and neck squamous cell carcinomas worldwide: a systematic review. Cancer Epidemiol Biomarkers Prev 2005;14:467-75.

8. Klussmann JP, Weissenborn S., Wieland U., Dries V., Kolligs J., Jungehuelsing M, et al. Prevalence, Distribution And Viral Load Of Human Papillomavirus 16 DNA In Tonsillar Carcinomas. Cancer 2001;92:2875-84.

9. D'Souza G, Kreimer AR, Viscidi R, Pawlita M, Fakhry C, Koch WM, et al. Casecontrol study of human papillomavirus and oropharyngeal cancer. $N$ Engl J Med 2007;356:1944-56.

10. Ragin CC, Taioli E. Survival of squamous cell carcinoma of the head and neck in relation to human papillomavirus infection: Review and meta-analysis. Int J Cancer 2007;121:1813-20.

11. Reimers N, Kasper HU, Weissenborn SJ, Stutzer H, Preuss SF, Hoffmann TK, et al. Combined analysis of HPV-DNA, p16 and EGFR expression to predict prognosis in oropharyngeal cancer. Int J Cancer 2007;120:1731-8.

12. Hafkamp HC, Manni JJ, Haesevoets A, Voogd AC, Schepers M, Bot FJ, et al. Marked differences in survival rate between smokers and nonsmokers with HPV 16-associated tonsillar carcinomas. Int J Cancer 2008;122:2656-64.

13. Fakhry C, Westra WH, Li S, Cmelak A, Ridge JA, Pinto H, et al. Improved survival of patients with human papillomavirus-positive head and neck squamous cell carcinoma in a prospective clinical trial. J Natl Cancer Inst 2008;100:261-9.

14. Lo ML, D'Angelo M, Procaccini M, Bambini F, Calvino F, Florena AM, et al. Expression of cell cycle markers and human papillomavirus infection in oral squamous cell carcinoma: use of fuzzy neural networks. Int $J$ Cancer 2005;115: 717-23.

15. Preuss SF, Weinell A, Molitor M, Stenner M, Semrau R, Drebber U, et al. Nuclear survivin expression is associated with HPV-independent carcinogenesis and is an indicator of poor prognosis in oropharyngeal cancer. Br J Cancer 2008;98:627-32.

16. Hafkamp HC, Mooren JJ Claessen SM, Klingenberg B, Voogd AC, Bot FC, et al. P21 Cip1/WAF1 expression is strongly associated with HPV-positive tonsillar carcinoma and a favorable prognosis. Mod Pathol 2009;22:686-98. 
17. Hafkamp HC, Speel EJ, Haesevoets A, Bot FJ, Dinjens WN, Ramaekers FC, et al. A subset of head and neck squamous cell carcinomas exhibits integration of HPV $16 / 18$ DNA and overexpression of p16INK4A and p53 in the absence of mutations in p53 exons 5-8. Int J Cancer 2003;107:394-400.

18. Balz V, Scheckenbach K, Gotte K, Bockmuhl U, Petersen I, Bier H. Is the p53 Inactivation Frequency in Squamous Cell Carcinomas of the Head and Neck Underestimated? Analysis of p53 Exons 2-11 and Human Papillomavirus 16/18 E6 Transcripts in 123 Unselected Tumor Specimens. Cancer Res 2003;63:1188-91.

19. van Houten VM, Snijders PJ, van den Brekel MW, Kummer JA, Meijer CJ, van Leeuwen $B$, et al. Biological evidence that human papillomaviruses are etiologically involved in a subgroup of head and neck squamous cell carcinomas. Int $J$ Cancer 2001;93:232-5.

20. Klussmann JP, Gultekin E, Weissenborn SJ, Wieland U, Dries V, Dienes HP, et al. Expression of p16 Protein Identifies a Distinct Entity of Tonsillar Carcinomas Associated with Human Papillomavirus. Am J Pathol 2003;162:747-53.

21. Wittekindt C, Gultekin E, Weissenborn SJ, Dienes HP, Pfister HJ, Klussmann JP. Expression of $\mathrm{p} 16$ protein is associated with human papillomavirus status in tonsillar carcinomas and has implications on survival. Adv Otorhinolaryngol 2005;62:72-80.

22. Smeets SJ, Hesselink AT, Speel EJ, Haesevoets A, Snijders PJ, Pawlita M, et al. A novel algorithm for reliable detection of human papillomavirus in paraffin embedded head and neck cancer specimen. Int J Cancer 2007;121:2465-72.

23. Gillison ML. Human papillomavirus-associated head and neck cancer is a distinct epidemiologic, clinical, and molecular entity. Semin Oncol 2004;31:744-54.

24. Klussmann JP, Weissenborn SJ, Wieland U, Dries V, Eckel HE, Pfister HJ, et al. Human papillomavirus-positive tonsillar carcinomas: a different tumor entity? Med Microbiol Immunol 2003;192:129-32.

25. Mao L, Hong WK, Papadimitrakopoulou VA. Focus on head and neck cancer. Cancer Cell 2004;5:311-6.

26. Veltman JA, van W, I, Aubele M, Bot FJ, Ramaekers FC, Manni JJ, et al. Specific steps in aneuploidization correlate with loss of heterozygosity of 9p21,17p13 and $18 q 21$ in the progression of pre-malignant laryngeal lesions. Int $J$ Cancer 2001;91:193-9.

27. Bockmuhl U, Schluns K, Schmidt S, Matthias S, Petersen I. Chromosomal alterations during metastasis formation of head and neck squamous cell carcinoma. Genes Chromosomes Cancer 2002;33:29-35.

28. Gollin SM. Chromosomal alterations in squamous cell carcinomas of the head and neck: window to the biology of disease. Head Neck 2001;23:238-53.

29. Beder LB, Gunduz M, Ouchida M, Fukushima K, Gunduz E, Ito S, et al. Genomewide analyses on loss of heterozygosity in head and neck squamous cell carcinomas. Lab Invest 2003;83:99-105.

30. Wreesmann VB, Shi W, Thaler HT, Poluri A, Kraus DH, Pfister D, et al. Identification of novel prognosticators of outcome in squamous cell carcinoma of the head and neck. J Clin Oncol 2004;22:3965-72.

31. Bockmuhl U, Schluns K, Kuchler I, Petersen S, Petersen I. Genetic imbalances with impact on survival in head and neck cancer patients. Am J Pathol 2000;157: 369-75.

32. Heselmeyer K, Schrock E, du MS, Blegen H, Shah K, Steinbeck R, et al. Gain of chromosome $3 q$ defines the transition from severe dysplasia to invasive carcinoma of the uterine cervix. Proc Natl Acad Sci U S A 1996;93:479-84. 
33. Huang FY, Kwok YK, Lau ET, Tang MH, Ng TY, Ngan HY. Genetic abnormalities and HPV status in cervical and vulvar squamous cell carcinomas. Cancer Genet Cytogenet 2005;157:42-8.

34. Snijders PJ, Steenbergen RD, Heideman DA, Meijer CJ. HPV-mediated cervical carcinogenesis: concepts and clinical implications. J Pathol 2006;208:152-64.

35. Heselmeyer-Haddad K, Sommerfeld K, White NM, Chaudhri N, Morrison LE, Palanisamy N, et al. Genomic amplification of the human telomerase gene (TERC) in pap smears predicts the development of cervical cancer. Am J Pathol 2005; 166:1229-38.

36. Wieland U, Brockmeyer NH, Weissenborn SJ, Hochdorfer B, Stucker M, Swoboda $\mathrm{J}$, et al. Imiquimod treatment of anal intraepithelial neoplasia in HIV-positive men. Arch Dermatol 2006;142:1438-44.

37. Greene FL, Page DL, Fleming ID, Fritz AG, Blach CM, Haller DG, et al. American Joint Committee on Cancer Staging Manual. 6 ed. Berlin, New York: Springer; 2002.

38. Pindbord JJ, Reichart PA, Smith CJ, van der Waal I. Histological typing of cancer and precancer of the oral mucosa. 2 ed. Berlin, New York: Springer; 1997.

39. Speel EJ, Scheidweiler AF, Zhao J, Matter C, Saremaslani P, Roth J, et al. Genetic evidence for early divergence of small functioning and nonfunctioning endocrine pancreatic tumors: gain of $9 \mathrm{Q} 34$ is an early event in insulinomas. Cancer Res 2001;61:5186-92.

40. Forastiere A, Koch W, Trotti A, Sidransky D. Head and neck cancer. N Engl J Med 2001;345:1890-900.

41. Califano J, van der RP, Westra W, Nawroz H, Clayman G, Piantadosi S, et al. Genetic progression model for head and neck cancer: implications for field cancerization. Cancer Res 1996;56:2488-92.

42. Smeets SJ, Braakhuis BJ, Abbas S, Snijders PJ, Ylstra B, van de Wiel MA, et al. Genome-wide DNA copy number alterations in head and neck squamous cell carcinomas with or without oncogene-expressing human papillomavirus. Oncogene 2006;25:2558-64.

43. Dahlgren L, Mellin H, Wangsa D, Heselmeyer-Haddad K, Bjornestal L, Lindholm J, et al. Comparative genomic hybridization analysis of tonsillar cancer reveals a different pattern of genomic imbalances in human papillomavirus-positive and negative tumors. Int J Cancer 2003;107:244-9.

44. Hopman AH, Theelen W, Hommelberg PP, Kamps MA, Herrington CS, Morrison LE, et al. Genomic integration of oncogenic HPV and gain of the human telomerase gene TERC at $3 q 26$ are strongly associated events in the progression of uterine cervical dysplasia to invasive cancer. J Pathol 2006;210:412-9.

45. Martin CL, Reshmi SC, Ried T, Gottberg W, Wilson JW, Reddy JK, et al. Chromosomal imbalances in oral squamous cell carcinoma: Examination of 31 cell lines and review of the literature. Oral Oncol 2008;44:369-82.

46. Qian J, Massion PP. Role of chromosome $3 q$ amplification in lung cancer. J Thorac Oncol 2008;3:212-5.

47. Smith L, Liu SJ, Goodrich L, Jacobson D, Degnin C, Bentley N, et al. Duplication of ATR inhibits MyoD, induces aneuploidy and eliminates radiation-induced G1 arrest. Nat Genet 1998;19:39-46.

48. Lockwood WW, Chari R, Chi B, Lam WL. Recent advances in array comparative genomic hybridization technologies and their applications in human genetics. Eur $\mathrm{J}$ Hum Genet 2006;14:139-48. 
49. Ma YY, Wei SJ, Lin YC, Lung JC, Chang TC, Whang-Peng J, et al. PIK3CA as an oncogene in cervical cancer. Oncogene 2000;19:2739-44.

50. Kanao H, Enomoto T, Kimura T, Fujita M, Nakashima R, Ueda $Y$, et al. Overexpression of LAMP3/TSC403/DC-LAMP promotes metastasis in uterine cervical cancer. Cancer Res 2005;65:8640-5.

51. Lopez CD, Martinovsky G, Naumovski L. Inhibition of cell death by ribosomal protein L35a. Cancer Lett 2002;180:195-202.

52. Fan CS, Wong N, Leung SF, To KF, Lo KW, Lee SW, et al. Frequent c-myc and Int-2 overrepresentations in nasopharyngeal carcinoma. Hum Pathol 2000;31: 169-78.

53. Ragin CC, Taioli E, Weissfeld JL, White JS, Rossie KM, Modugno F, et al. 11q13 amplification status and human papillomavirus in relation to $\mathrm{p} 16$ expression defines two distinct etiologies of head and neck tumours. Br J Cancer 2006;95:1432-8.

54. Reshmi SC, Roychoudhury S, Yu Z, Feingold E, Potter D, Saunders WS, et al. Inverted duplication pattern in anaphase bridges confirms the breakage-fusionbridge (BFB) cycle model for 11q13 amplification. Cytogenet Genome Res 2007; 116:46-52.

55. Jin $Y$, Hoglund $M$, Jin C, Martins C, Wennerberg J, Akervall J, et al. FISH characterization of head and neck carcinomas reveals that amplification of band $11 \mathrm{q} 13$ is associated with deletion of distal 11q. Genes Chromosomes Cancer 1998;22:312-20.

56. Wentzensen N, Vinokurova S, von Knebel DM. Systematic review of genomic integration sites of human papillomavirus genomes in epithelial dysplasia and invasive cancer of the female lower genital tract. Cancer Res 2004;64:3878-84.

57. Choi YW, Bae SM, Kim YW, Lee HN, Kim YW, Park TC, et al. Gene expression profiles in squamous cell cervical carcinoma using array-based comparative genomic hybridization analysis. Int J Gynecol Cancer 2007;17:687-96.

58. Steenbergen RD, Hermsen MA, Walboomers JM, Joenje H, Arwert F, Meijer CJ, et al. Integrated human papillomavirus type 16 and loss of heterozygosity at $11 \mathrm{q} 22$ and 18q21 in an oral carcinoma and its derivative cell line. Cancer Res 1995;55:5465-71.

59. Fromont G, Valeri A, Cher M, Pontes JE, Vallancien G, Validire P, et al. Allelic loss at $16 q 23.2$ is associated with good prognosis in high grade prostate cancer. Prostate 2005;65:341-6.

60. Hansen LL, Yilmaz M, Overgaard J, Andersen J, Kruse TA. Allelic loss of 16q23.224.2 is an independent marker of good prognosis in primary breast cancer. Cancer Res 1998;58:2166-9.

61. Bosch FX, Andl C, Abel U, Kartenbeck J. E-cadherin is a selective and strongly dominant prognostic factor in squamous cell carcinoma: a comparison of $\mathrm{E}$ cadherin with desmosomal components. Int J Cancer 2005;114:779-90.

62. Smith DI, McAvoy S, Zhu Y, Perez DS. Large common fragile site genes and cancer. Semin Cancer Biol 2007;17:31-41. 


\section{Chapter}

\section{CHROMOSOME STABILITY IN TONSILLAR SQUAMOUS CELL CARCINOMA IS ASSOCIATED WITH HPV16 INTEGRATION AND INDICATES A FAVOURABLE PROGNOSIS}

Jeroen J Mooren, Bernd Kremer, Sandra MH Kremer-Claessen, Adri C Voogd,

Frederik J Bot, J Peter Klussmann, Christian U Huebbers, Anton HN Hopman, Frans CS Ramaekers, Ernst-Jan M Speel

International Journal of Cancer 2013;132:1781-1789 


\section{Abstract}

Tonsillar squamous cell carcinoma (TSCC) is frequently associated with human papillomavirus (HPV) and chromosome instability. Data from cellular model systems are, however, controversial concerning a relation between HPV and chromosome instability development. Here we studied this association in 77 primary TSCC with known clinical outcome and cell cycle protein expression profiles. Thirty-two tumours (42\%) showed HPV16-integration. All 77 cases were analyzed by fluorescence in situ hybridization using chromosome 1- and 7-specific centromere DNA probes to detect chromosome instability, indicated by the presence of chromosome imbalances and/or polyploidization for these chromosomes. In addition, eight HPV-positive dysplasias, seven of which were adjacent to a carcinoma, were analyzed.

Disomy for chromosome 1 and 7 was present in 29 out of 77 TSCC (38\%), of which 19 were HPV16-positive $(p=0.002)$. Aneusomy was observed in the remaining 48 TSCC, of which 13 were HPV-positive. Aneusomies correlated significantly with tobacco- and alcohol consumption ( $p=0.001$ and $p=0.016$, respectively) and a higher T-stage $(p=0.018)$. Both HPV-positivity and chromosome disomy were significantly associated with a favourable disease-free survival ( $p=0.001$ and $p=0.025$, respectively). Particularly in the HPV16-positive group chromosome instability is a very strong indicator for an unfavourable prognosis $(p=0.032)$. In the dysplasias an identical HPV and chromosome copy number status was identified as in the adjacent tumours. We conclude that HPV-positive TSCC and their precursor lesions are more often genetically stable than HPV-negative lesions and that these tumours are associated with a favourable prognosis. Chromosome instability is an indicator for unfavourable prognosis, particularly in the HPV-positive patient group. 


\section{Introduction}

Chromosome instability or aneuploidy is a characteristic of most solid tumours, including head and neck squamous cell carcinoma (HNSCC). Chromosome instability refers to changes in chromosome number (gains or losses), amongst others caused by failures in mitotic chromosome transmission and disturbances in the polarity of cell division. ${ }^{1}$ Previous flow cytometric studies have shown that chromosome instability is often present in primary HNSCC and their metastases, with an incidence ranging from $44-90 \% .{ }^{2,3}$ Similar frequencies were found using other technologies detecting chromosome instability, such as microsatellite analysis, comparative genomic hybridization $(\mathrm{CGH})$, fluorescence in situ hybridization (FISH), or using chromosome instability-associated p53-immunostaining. ${ }^{4-6}$ We and others have shown that alterations in chromosome 1 and 7 copy numbers detected by FISH are frequently found in head and neck (pre)malignancies. ${ }^{7,8}$ On the basis of imbalances in chromosome 1 and 7 copy number ratios, we were able to reliably predict malignant progression and tumour recurrence. ${ }^{8-10}$ In these cases, the chromosome 1 copy number most often equalled the average copy number of all chromosomes (ploidy) in the lesions, whereas generally higher copy numbers for chromosome 7 were detected. The latter finding is also reflected by data of Benchekroun et al. reporting increased epidermal growth factor receptor (EGFR) gene copy numbers on chromosome 7 in premalignant oral leukoplakia that progressed to carcinoma. ${ }^{11}$

Mutations in, e.g., the p16 and p53 genes in early head and neck carcinogenesis are associated with well-known risk factors, such as smoking and alcohol consumption, whereas wildtype p16 and p53 are often found in tumours associated with oncogenic human papillomavirus (HPV). The deregulation of the p53 and pRb pathways in both HPV related and -unrelated carcinogenic routes will ultimately result in a deregulation of the cell cycle and of the apoptotic process, finally leading to chromosome instability. ${ }^{12,13}$

The occurrence of chromosome instability is considered to be a late event in HPV related carcinogenesis. In vitro studies with HPV-E6/E7 immortalized keratinocytes and raft cultures have shown that a persistent HPV infection is not sufficient for malignant transformation. ${ }^{14-16}$ This transformation can be achieved by treating them for example with tobacco mutagens. ${ }^{17}$ However, patients with HPV-positive carcinomas are significantly less likely found in smokers and drinkers. ${ }^{18-20}$ Alternatively, several in vitro transcription studies have shown chromosome and centrosome alterations to occur as a result of high levels of the HPV-oncoproteins E6 and E7,,$^{21-23}$ although the role of the individual proteins in this process remains controversial. ${ }^{24,25}$

We and others have shown that in uterine cervix cancer oncogenic HPV integration is associated with the transition from cervical intraepithelial 
neoplasia to invasive carcinoma. ${ }^{26,27}$ Viral integration is often accompanied by an upregulation of the oncoproteins $\mathrm{E} 6$ and $\mathrm{E} 7$, and subsequently chromosome instability. ${ }^{26,28}$ Nevertheless, viral integration has been detected in both diploid and aneuploid cervical cancer lesions. ${ }^{27}$ Upregulation of E6 and E7 due to viral integration is also suggested to occur during the development of tonsillar squamous cell carcinoma (TSCC), in which there is a high prevalence of oncogenic HPV $(30-75 \%){ }^{18,20,29-32}$ The question therefore is if HPV integration will also lead to chromosome instability in primary HPV-positive TSCC, and whether or not chromosome instability can be detected in the same frequency as in HPV-negative tumours?

The aim of the present study was to analyse a series of 77 TSCC for chromosome instability by means of FISH using chromosome 1 and 7 -specific centromere probes. Chromosome copy number-data were correlated with the HPV16 status, as well as clinical and lifestyle parameters. ${ }^{31,33}$ Furthermore, we were able to select eight additional HPV-positive tonsillar dysplasias, seven of which were found adjacent to a TSCC, for comparison of chromosomal (in)stability and the physical status of HPV.

\section{Materials and methods}

\section{Tumour material and patient data}

We analysed formaldehyde fixed, paraffin embedded archival biopsy and resection material of primary TSCC from 77 patients, selected from the archives of the department of Pathology, Maastricht University Medical Centre, The Netherlands and the department of Pathology, University of Cologne, Germany.

Patients were diagnosed between 1992 and 2001. Sections had been previously examined for HPV16 and -18 association by type specific FISH and PCR and cell cycle protein expression profiles. ${ }^{19,33}$ Patient material was used according to the code for proper secondary use of human tissue (Federation of Medical Scientific Societies, The Netherlands; 2003). Demographic data, tumour site, degree of differentiation, TNM classification and clinical follow-up data of all patients were available. ${ }^{19}$ Patients have been treated by surgery, radiotherapy, chemotherapy or a combination, irrespective of HPV status. Fiftyfive patients were male and 22 patients were female. The mean age at diagnosis was 60 (range 39-87) years. Smoking and alcohol-intake data were available for 77 and 76 patients, respectively. Sixty-one (79\%) of the 77 patients were smokers ( $\geq 1$ cigarette, pipe, and/or cigar per day), $42(55 \%)$ of 76 patients were classified as drinkers (consumption of $>2$ whiskey equivalents per day ( 1 whiskey equivalent $\sim 10 \mathrm{~g}$ alcohol)) and 38 (49\%) patients used both. Thirty-eight (49\%) patients had a tumour with a diameter 
$\geq 4 \mathrm{~cm}$, and $57(74 \%)$ had lymph node metastasis at time of diagnosis. The male/female ratio and the age at first diagnosis were similar for the HPV-positive and HPV-negative group. Smoking and drinking was significantly correlated with an HPV-negative tumour ( $p<0.0001$ and $p=0.002$, respectively). In addition, we analyzed one dysplasia and seven tumours and adjacent tissue that had the appearance of - and were classified as dysplasia. Also the tumour areas were analysed for comparison. This tissue material was obtained from the archives of the Department of Pathology, University of Cologne, Germany.

A series of $4 \mu \mathrm{m}$-thick sections was cut from the specimens for hematoxylineosin staining and detailed histopathological classification, according to the criteria of the World Health Organization. ${ }^{34}$ On consecutive sections HPV-status was determined by HPV-specific PCR followed by FISH analysis. Double-target FISH analysis was applied using chromosome 1- and 7-specific centromere DNA probes.

\section{FISH analysis}

\section{Chromosome 1 and 7 copy number analysis}

FISH was performed on $4 \mu \mathrm{m}$-thick tissue sections as described previously. ${ }^{9,35}$ Briefly, sections were deparaffinized, pre-treated with $85 \%$ formic acid/0.3\% $\mathrm{H}_{2} \mathrm{O}_{2}, 1 \mathrm{M} \mathrm{NaSCN}$ and $4 \mathrm{mg} / \mathrm{ml}$ pepsin, postfixed in $1 \%$ formaldehyde in PBS $(\mathrm{pH} 7.4)$, dehydrated in an ethanol series and hybridized with a mixture of digoxigenin-labeled human centromere 1-specific and biotin-labeled centromere 7 -specific DNA probes $(1 \mathrm{ng} / \mu \mathrm{l} 60 \%$ formamide, $2 x$ saline sodium citrate (SSC), 10\% dextran sulphate and 50x excess salmon sperm carrier DNA). After hybridization the preparations were washed stringently in $2 \times S S C$ at $42^{\circ} \mathrm{C}$ (two times $5 \mathrm{~min}$ ) and $0.1 \times S S C$ at $60^{\circ} \mathrm{C}$ (two times $5 \mathrm{~min}$ ).

Both probes were detected simultaneously, using (i) mouse anti-digoxin (Sigma, St. Louis, MO), (ii) rabbit anti-mouse rhodamine (DAKO A/S, Glostrup, Denmark), and (iii) swine anti-rabbit rhodamine (DAKO A/S) for the digoxigenin-labeled probe and (i) avidin fluorescein (Vector Laboratories, Burlingame, CA), (ii) biotinylated goat anti-avidin (Vector), and (iii) avidin fluorescein for the biotin-labeled probe. Preparations were mounted in Vectashield (Vector Laboratories, Burlingame, CA) containing 4,6-diamidino-2phenyl indole (DAPI; Sigma: $0.2 \mathrm{~g} / \mathrm{ml}$ ).

Slides were evaluated under the microscope and images were recorded with the Metasystems Image Pro System (black and white CCD camera; Sandhausen, Germany) mounted on top of a Leica DM-RE fluorescence microscope equipped with DAPI, fluorescein and rhodamine filters.

Evaluation of the FISH results was carried out according to the criteria previously described. ${ }^{10,35}$ FISH signals were scored per colour and nucleus for 
the presence of aberrant copy numbers. The highest copy number per nucleus was determined and set if $\geq 20 \%$ of the nuclei (50-200 nuclei are counted, depending on the size of the lesion) showed this number of FISH signals. Based on this evaluation, areas were categorized as either monosomic, disomic, trisomic, tetrasomic or polysomic ( $>4$ signals per nucleus) for the respective probe targets. Next, the lesions were divided into a group of lesions without evidence of chromosome alterations (disomic), and a group of lesions showing either altered but balanced chromosome copy numbers (trisomy or tetrasomy) or characteristics of chromosome instability, i.e., containing chromosome copy number imbalances and/or chromosome polysomy (indicative for aneuploidy). ${ }^{9}$

\section{HPV analysis}

HPV FISH was performed on $4 \mu \mathrm{m}$-thick tissue sections as described previously. ${ }^{31}$ Briefly, sections were pretreated as described above and hybridized with a digoxigenin-labeled HPV 16-specific probe (PanPath, Budel, The Netherlands) according to the manufacturer's instructions. After stringent washing in $50 \%$ formamide, $2 \times \mathrm{SSC}, \mathrm{pH} 7.0$ at $42^{\circ} \mathrm{C}$ (two times $5 \mathrm{~min}$ ), probe hybridisation was visualized by subsequent incubations with mouse antidigoxin (Sigma), peroxidase-conjugated rabbit anti-mouse IgG, peroxidaseconjugated swine anti-rabbit IgG (both DAKO A/S) and finally rhodaminelabeled tyramide. Preparations were mounted, evaluated and recorded as described above.

Evaluation of nuclear hybridization signals was performed by two investigators (JM and EJMS) according to previously described criteria: ${ }^{31}$ nuclear punctate signals were considered to indicate integrated HPV DNA and diffuse signals to indicate episomal HPV DNA. Also a granular FISH pattern, defined as the presence of several nuclear signals varying significantly in size and intensity, was observed in a few cases, which may indicate a combination of viral integration and episomal DNA and/ or viral RNA. ${ }^{31}$

\section{Statistical analysis}

Previously assessed clinical and molecular parameters were correlated with chromosome instability and HPV-status using cross-tabulations and the twotailed Fisher exact test and/or Chi-square test. ${ }^{33}$ We regarded a p-value $\leq 0.05$ as level of significance. The Kaplan-Meier method was used to calculate disease-specific survival curves. Survival was calculated from the date of diagnosis until patient's death or until the last date the patient was known to be alive (this ranged from 16-141 months). Patients that died of other causes than tonsillar carcinoma were considered censored observations in the diseasespecific survival analyses. Disease-free survival was calculated from the date of diagnosis until the date of recurrence (local, regional or distant, whichever 
occurred first). Patients without recurrence were censored at the date of the last follow-up or the date of death. The statistical significance of differences between survival times was determined by the log rank test in univariate analysis. Multivariate analyses were performed using the Cox proportional hazards model. Variables remained in the model if their $p$-values were below 0.10. We used the SPSS Base System version 18.0 for all calculations.

\section{Results}

\section{HPV16-positivity in TSCC is correlated with chromosome stability}

Figure 5.1 shows the distribution of the HPV and chromosome copy number status amongst the 77 TSCC examined in this study. We have analyzed chromosome 1 and 7 alterations and HPV16 integration status using FISH, and the expression of $\mathrm{p} 16^{\text {INK4A }}$ using immunohistochemistry. We found 32 HPV16-positive cases, as indicated by overexpression of $\mathrm{p} 16^{\mathrm{INK} 4}$, and a punctate HPV16 signal in 31 cases and a granular pattern in 1 case (Figure 5.1). Predominantly single HPV16 integration sites per tumour cell nucleus were found, except for six cases that exhibited two integration sites per nucleus by FISH. Two of these were found in an aneusomic tumour. The other 4 were observed in diploid TSCC, which also exhibited tumour areas containing cells with only 1 HPV16 integration site by FISH. These TSCC might have undergone tetraploidization with duplication of the viral integration site, despite the fact that we could not find the tetraploidization of chromosomes 1 and 7 in these cases.

Disomy for chromosome 1 and 7 was found in 29 out of 77 TSCC (38\%). Nineteen of these were HPV16-positive ( $p=0.002$ ), including 11 nonsmokers (of 16 nonsmoking patients in total). Figures $5,2 \mathrm{~A}-\mathrm{C}$ show a typical example of an HPV16-positive tumour in which a strong positivity for the HPV surrogate marker $\mathrm{p} 16^{\mathrm{INK} 4 \mathrm{~A}}$ (Figure 5.2A), a punctate FISH HPV pattern indicating integration (Figure 5.2B), and disomy for chromosome 1 and 7 (Figure 5.2C) can be observed.

Aneusomies for both chromosomes were observed in 48 out of 77 TSCC (62\%), of which 28 tumours showed balanced and 20 showed unbalanced copy numbers (19 cases with a higher chromosome 7 copy number). Aneusomies correlated significantly with HPV-negative tumours $(p=0.002)$ (Figure 5.1 and Figures 5.2D-E), tobacco- and alcohol consumption $(p=0.001$ and $p=0.016$, respectively) and a higher $T$-stage $(p=0.018)$. Strong $p 53$ immunostaining was also associated with HPV-negative tumours $(p=0.003)$ and smoking and/or alcohol abuse $(p=0.005)$, but not with aneusomy and T-stage. ${ }^{33}$ 


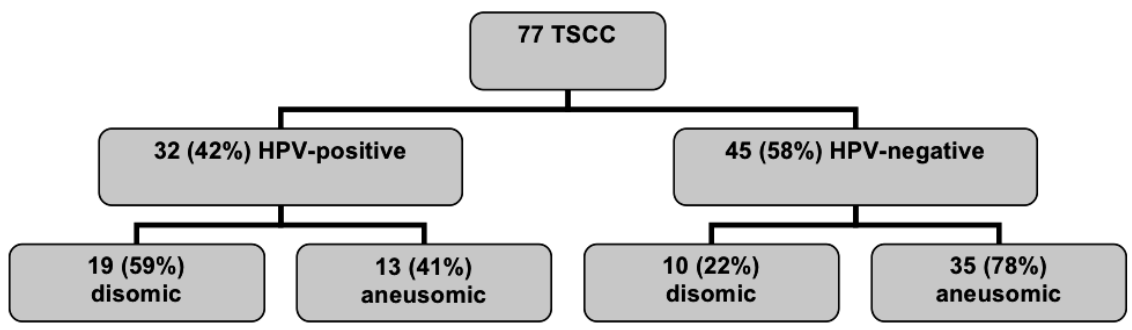

Figure 5.1 Overview of the HPV16 and chromosome $1 / 7$ status in 77 cases of TSCC. Disomy is significantly associated with HPV16-positivity in TSCC, whereas aneusomy is associated with HPV16-negative carcinomas $(p=0.002)$.

\section{HPV16-positive TSCC and adjacent dysplasias show similar HPV patterns and chromosome copy numbers}

We were able to compare the occurrence of chromosome instability between HPV-positive tumours and their adjacent dysplastic lesions in seven cases. In both tumours and dysplasias strong nuclear and cytoplasmatic p16 ${ }^{\text {INK4A }}$ immunostaining (Figures 5.2F-I) was observed and found to be associated with HPV16-positivity as determined by FISH (Table 5.1). A punctate HPV pattern was predominantly detected, indicating viral integration in both the dysplastic and malignant lesions. In addition, similar chromosome copy numbers were identified in the tumours and the adjacent dysplastic areas, including cases with disomy, tetrasomy and aneusomy. Interestingly, two cases showed both disomic and aneusomic cell clusters adjacent to each other already in the dysplastic lesion. Case number 6 (Table 5.1) showed different HPV patterns (punctate and granular) in relation to disomic and aneusomic cells, respectively, and only the disomic population in the TSCC showed a punctate HPV pattern. In contrast, case number 7 (Table 5.1) showed cell populations with a punctate HPV pattern and disomy or aneusomy in both the dysplasia and the carcinoma. In the dysplasia that was not associated with a TSCC (Table 5.1, Case 5.1) cells exhibited $\mathrm{p} 16^{\mathrm{INK} 4 \mathrm{~A}}$ immunopositivity, a punctate HPV16 pattern and disomy. 

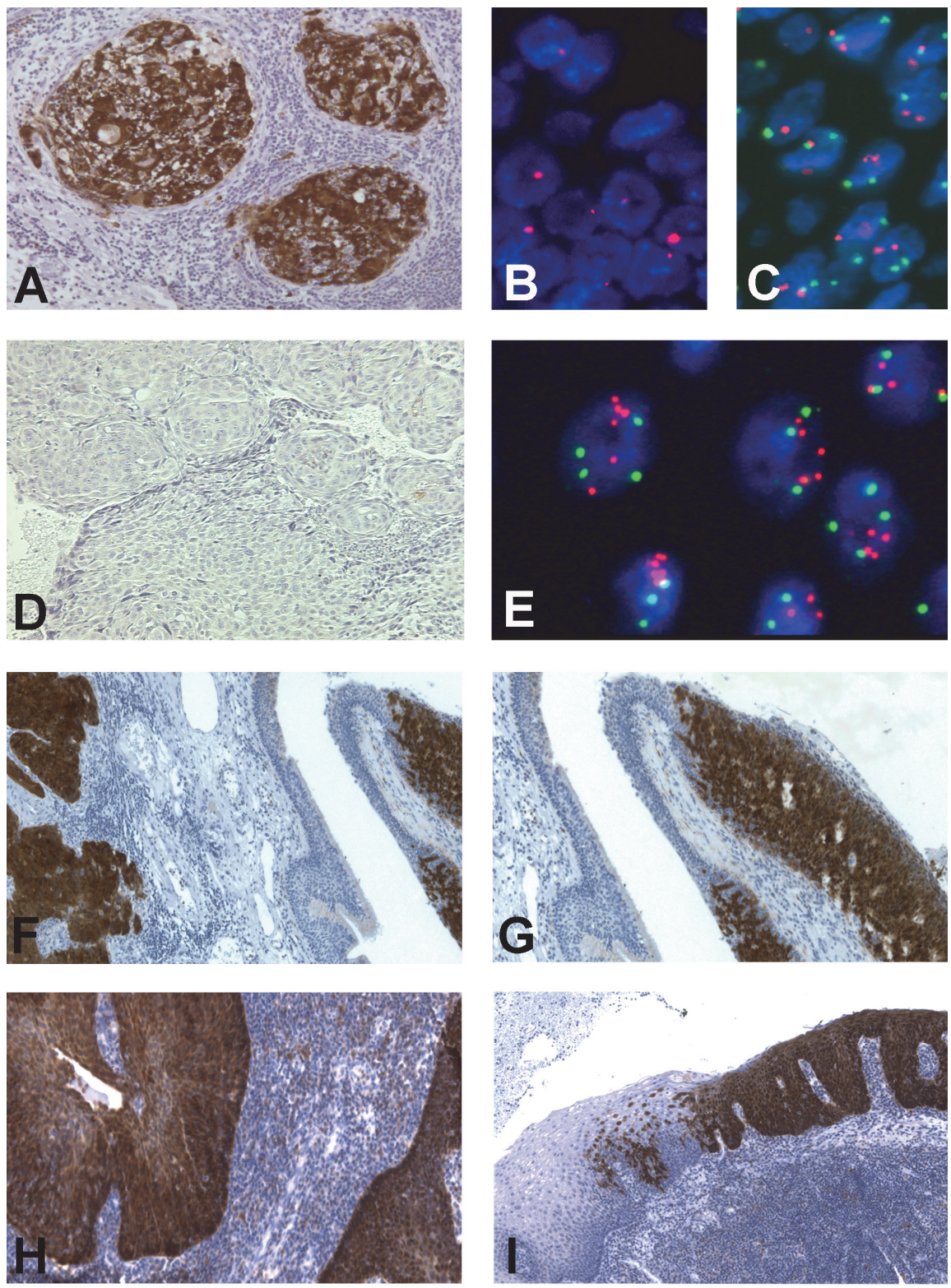

Figure 5.2 Representative examples of immunohistochemical staining for p16 ${ }^{\text {INK4A }}$ (A,D,F-I), as well as HPV16 FISH (B) and chromosome 1 and 7 double-target FISH analyses (C,E) on tissue sections of an HPV-positive TSCC (A-C), two HPV-positive TSCC and adjacent dysplasia (F-I), and an HPV-negative TSCC (D-E). (A) Strong nuclear and cytoplasmatic $\mathrm{p} 16^{\mathrm{INK} 4 \mathrm{~A}}$ immunostaining. (B) Punctate HPV16 FISH pattern indicating viral integration. (C) Disomy for chromosomes 1 and 7. (D) No $\mathrm{p} 16^{\mathrm{INK} 4 \mathrm{~A}}$ immunostaining. (E) Aneusomy for chromosomes 1 and 7. (F-I) Strong nuclear and cytoplasmatic $\mathrm{p} 16^{\mathrm{INK} 4 \mathrm{~A}}$ immunostaining in TSCC number 2 ( $\mathrm{F}$ left side) and its adjacent dysplasia (F right side, $\mathbf{G}$ ), and in TSCC number $8(\mathbf{H})$ and its adjacent dysplasia (I). 


\section{HPV16-positivity and chromosome stability are associated with a favourable prognosis}

We correlated HPV16 and chromosomal copy number status with the diseasespecific survival (DSS) data of patients with TSCC to determine the role of these two parameters as indicators of prognosis. Follow-up time ranged from 0 to 141 months, with a mean of 33 months. Thirty-nine $(48 \%)$ out of 75 patients died as a consequence of TSCC. The DSS after 5 years was $30 \%$ for patients with an HPV-negative carcinoma and $74 \%$ for patients with an HPV-positive carcinoma (Hazard ratio $(\mathrm{HR})=0.3 ; 95 \%$ Confidence Interval $(\mathrm{Cl})=0.1-0.6) \quad$ (Figure 5.3A). Also chromosome disomy was significantly associated with a favourable outcome in the entire group of TSCC (HR=0.4; $95 \% \mathrm{Cl}=0.2-0.9)$ (Figure 5.3B). Interestingly, in the patient group with HPV positive tumours chromosome disomy was an even stronger indicator of favourable prognosis $(\mathrm{HR}=0.2 ; \mathrm{Cl}=0.03-0.86)$ (Figure $5.3 \mathrm{C}$ ) as compared to the whole patient group. No prognostic association was observed for chromosome instability in the HPV-negative TSCC (Figure 5.3D). The HPV-positive aneusomic tumours (Figure $5.3 \mathrm{C}$ ) did not show significantly more often p53 overexpression.

Table 5.1 p16 $6^{\mathrm{INK} 4 \mathrm{~A}}-$, HPV16- and chromosome 1 and 7 copy number status in dysplastic lesions and their adjacent TSCC. Furthermore, the smoking behaviour of the 8 patients is indicated.

\begin{tabular}{|c|c|c|c|c|c|c|c|}
\hline \multirow[b]{2}{*}{ Number } & \multicolumn{3}{|c|}{ Dysplasia } & \multicolumn{3}{|c|}{ Carcinoma } & \multirow[t]{2}{*}{${ }^{1}$ Smoking } \\
\hline & ${ }^{2} \mathrm{P} 16^{\mathrm{INK} 4 \mathrm{~A}}$ & ${ }^{3} \mathrm{HPV} 16$ & ${ }^{4} \mathrm{Chr} \mathrm{1/7}$ & P16 ${ }^{\text {INK4A }}$ & HPV16 & Chr 1/7 & \\
\hline 51 & + & + & $\mathrm{D}$ & & & & ${ }^{6}$ N.A. \\
\hline 2 & + & + & D & + & + & D & Yes \\
\hline 3 & + & Granular & D & + & Granular & D & No \\
\hline 4 & + & + & $\mathrm{T}$ & + & + & $\mathrm{T}$ & Yes \\
\hline 5 & + & + & T & + & + & $T$ & No \\
\hline${ }^{7} 6$ & + & + and granular & $D$ and $A$ & + & + & D & No \\
\hline 7 & + & + & $D$ and $A$ & + & + & $D$ and $A$ & No \\
\hline 8 & + & + & A & + & + & A & Yes \\
\hline
\end{tabular}

${ }^{1}$ Smoking was defined as $\geq 1$ cigarette, pipe, and/or cigar per day; none of these patients were alcohol abusers (defined as consumption of $>2$ whiskey equivalents per day); ${ }^{2} \mathrm{P} 16^{\text {INK4A }}$ immunohistochemical data: + means strong nuclear and cytoplasmatic immunostaining; ${ }^{3}$ FISH data: + means punctate FISH pattern; ${ }^{4}$ Chromosome 1 and 7 copy numbers: $\mathrm{D}=$ disomy, $\mathrm{T}=$ tetrasomy, $\mathrm{A}=$ aneusomy; ${ }^{5}$ This case consists of a dysplastic lesion not associated with an adjacent TSCC; ${ }^{6}$ N.A. $=$ not available; ${ }^{7}$ This dysplastic lesion contained one part with small nuclei, punctated HPV and chromosome disomy and another part with large nuclei, granular HPV and polysomic chromosome numbers 
A

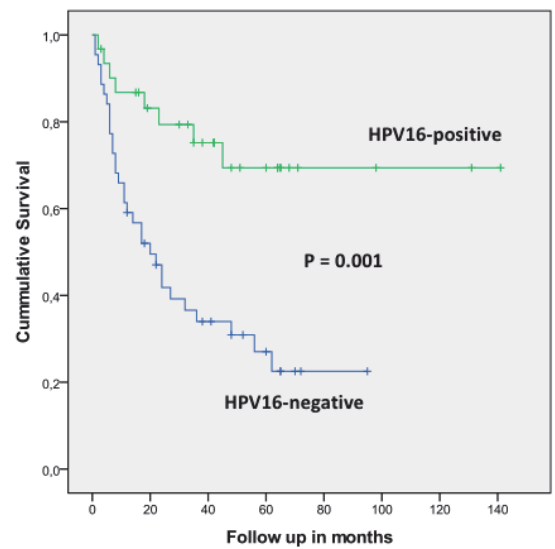

C

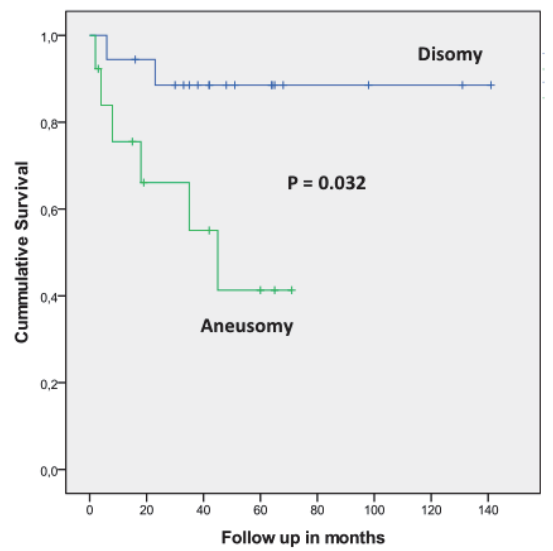

B

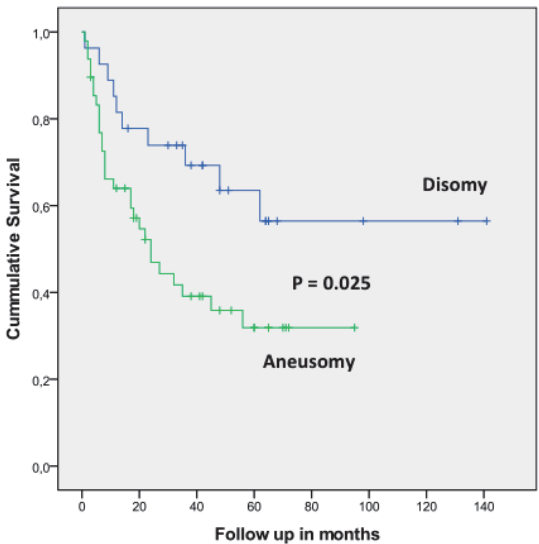

D

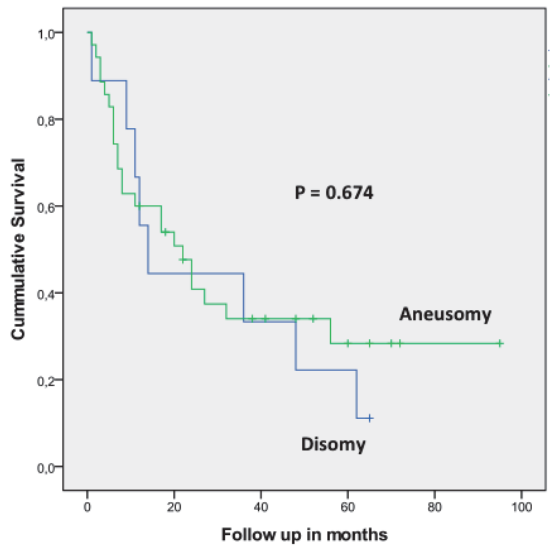

Figure 5.3 Kaplan-Meier survival curves according to (A) HPV16 status in 77 TSCC, (B) chromosomal (in)stability status in 77 TSCC, (C) chromosomal (in)stability status in the 32 HPV16-positive TSCC, and (D) chromosomal (in)stability status in the 45 HPV16-negative TSCC. On the plot, small vertical tick-marks indicate losses, where a patient's survival time has been right-censored.

\section{Discussion}

TSCC can be divided into at least two etiological subgroups, i.e., smoking/ alcohol induced and HPV induced tumours. Despite the different initiating factors and their different biological behaviour, ${ }^{12,36}$ both subgroups have been reported to develop chromosome instability as a late carcinogenic event, although some studies suggest that less genetic mutations occur in 
HPV-positive tumours. ${ }^{37,38}$ Data on the mechanisms of how HPV induces chromosome instability are particularly based on cell model experiments, in which the viral oncoproteins E6 and E7 are overexpressed. ${ }^{21-23}$ In the present study we analyzed the relation between the presence of HPV and the occurrence of chromosome instability in 77 primary TSCC, of which $32(42 \%)$ were HPV16-positive. We used FISH analysis to determine chromosome 1 and 7 copy number imbalances and/or polysomy, which is often associated with a more general chromosome instability., ${ }^{9,10}$ Our data show that chromosome stability was significantly associated with HPV-positivity. In contrast, chromosome instability was shown to correlate strongly with tobacco- and alcohol consumption, a higher T-stage and an unfavourable prognosis. Thus, primary HPV-positive TSCC predominantly exhibit a stable genome, which is a favourable prognosticator.

Several in vitro cell model studies using human keratinocytes and fibroblasts transfected with HPV16 E6, E7 or both, have reported that high expression levels of these viral oncoproteins can render these cells genomically unstable, thus predisposing them to accumulate chromosomal alterations. ${ }^{21-23}$ In this respect HPV16 E6 expressing cells exhibited evidence for structural chromosomal changes only after prolonged culturing, whereas HPV16 E7 expressing cells rapidly induced centrosome-related mitotic defects and chromosome instability. In the present study, however, we predominantly found chromosome stability in primary HPV-positive TSCC, which might be the result of lower expression levels of E6 and E7 than generated in the cell model studies. Indeed, a study by Lace et al., ${ }^{15}$ examining HPV persistence induced by HPV16, 18, 31 and 11 episomes in primary human keratinocytes from the foreskin, cervix and tonsils revealed that cell growth could be promoted by steady state E6 and E7 expression without the induction of chromosome instability. This raises the question which factor(s) besides the presence of HPV is (are) required for malignant progression in those cases where chromosome instability is not involved? Tobacco mutagens are not the only factor, because in this subgroup the highest frequency of nonsmokers is found. As stated above, chromosome instability was particularly observed in HPV-negative TSCC from heavy smokers. More likely factors for malignant progression in the HPV-positive group include the accumulation of confined chromosomal alterations, such as extra copies of chromosome $3 q$ found in HPV-positive uterine cervical cancers and TSCC, ${ }^{39-41}$ deletion of $16 q^{40,41}$ and/or modification of the methylation status of the host cell DNA. ${ }^{42,43}$ In addition, molecular alterations underlying lymphangiogenesis and epithelial mesenchymal transition might contribute to malignant tumour progression in these cases. ${ }^{44,45}$ 
Because most HPV-positive TSCCs are genomically stable, it could be expected that also their associated precursor lesions show this feature. Studies on premalignant tonsillar lesions are scarce, because patients usually enter the clinic with invasive tumours. Nevertheless, we were able to examine seven cases of HPV-positive TSCC with tumour-adjacent dysplasia found in the resection margins, and detected indeed in four cases disomy for chromosomes 1 and 7 in both the tumour and dysplastic lesion. This finding is in accordance with data on uterine cervical carcinogenesis, ${ }^{27}$ showing that HPV-integration can take place in diploid precursor lesions. In addition, we identified tetrasomy in two dysplastic lesions and their adjacent malignancies, and aneusomy for chromosomes 1 and 7 in three dysplastic lesions and two TSCC along with HPV integration, suggesting that HPV can also integrate into an unstable cellular genome. This has also been observed in uterine cervical preneoplasia, ${ }^{26,46}$ and might be the result of persistent infections and high viral loads in the (para)basal cells of the squamous epithelium, leading to chromosome instability before integration occurs. Another explanation might be that preneoplasia with chromosome instability is the result of DNA damage induced by for example heavy smoking, such as observed in case 8 (Table 5.1 ), although a larger series of dysplasias needs to be studied to underscore this hypothesis.

Also in our series of 77 TSCC, 13 out of 32 HPV-positive cases showed chromosome instability and these patients exhibited a significantly worse prognosis than those with chromosome stable tumours, although they were treated with comparable therapeutic regimes. Strikingly, 10 of these 13 tumours were diagnosed in smokers. In the literature smoking has been associated with an unfavourable prognosis in HPV-positive tumours as well. ${ }^{31,47}$

Because also other prognostic parameters have been reported, including $T$ and $\mathrm{N}$ status ${ }^{31,48}$ and EGFR expression, ${ }^{47,49}$ the construction of multiparameter models, based on large patient series, will be essential to optimally classify patients with a low, intermediate or high risk of cancer specific death. ${ }^{48,50}$

For HPV-positive HNSCC, Weinberger et al. ${ }^{13}$ proposed that HPV-positive and chromosome instability-containing tumours in smokers might be initially smoking-induced, after which HPV infection leads to its integration into the cellular genome ("hitchhiker model"). The typical characteristics of a smoking induced HNSCC comprise p53 mutations and downregulation of $\mathrm{p} 16^{\mathrm{INK} 4 \mathrm{~A}}$. However, we and others have shown that HPV-positive tumours, also in smokers, predominantly express high $\mathrm{p} 16^{\mathrm{INK} 4 \mathrm{~A}}$ levels and exhibit wild type p53. ${ }^{19,51}$ Therefore it is more likely that HPV integration occurs as an initial step in tetraploid or aneuploidy containing epithelial cells, most probably induced by high viral loads and not by p53 mutations as a result of smoking.

On the basis of our results, we propose a hypothetical model for HPV16 integration in relation to chromosome (in)stability during TSCC tumourigenesis 
(Figure 5.4), in which the latter is a key feature of survival in this patient group. In nonsmoking or sporadically smoking patients, TSCC predominantly show single HPV integration signals in a chromosome stable background. These TSCC most likely develop from diploid premalignant lesions. Some diploid TSCC may undergo duplication of the viral integration site or a second integration event.

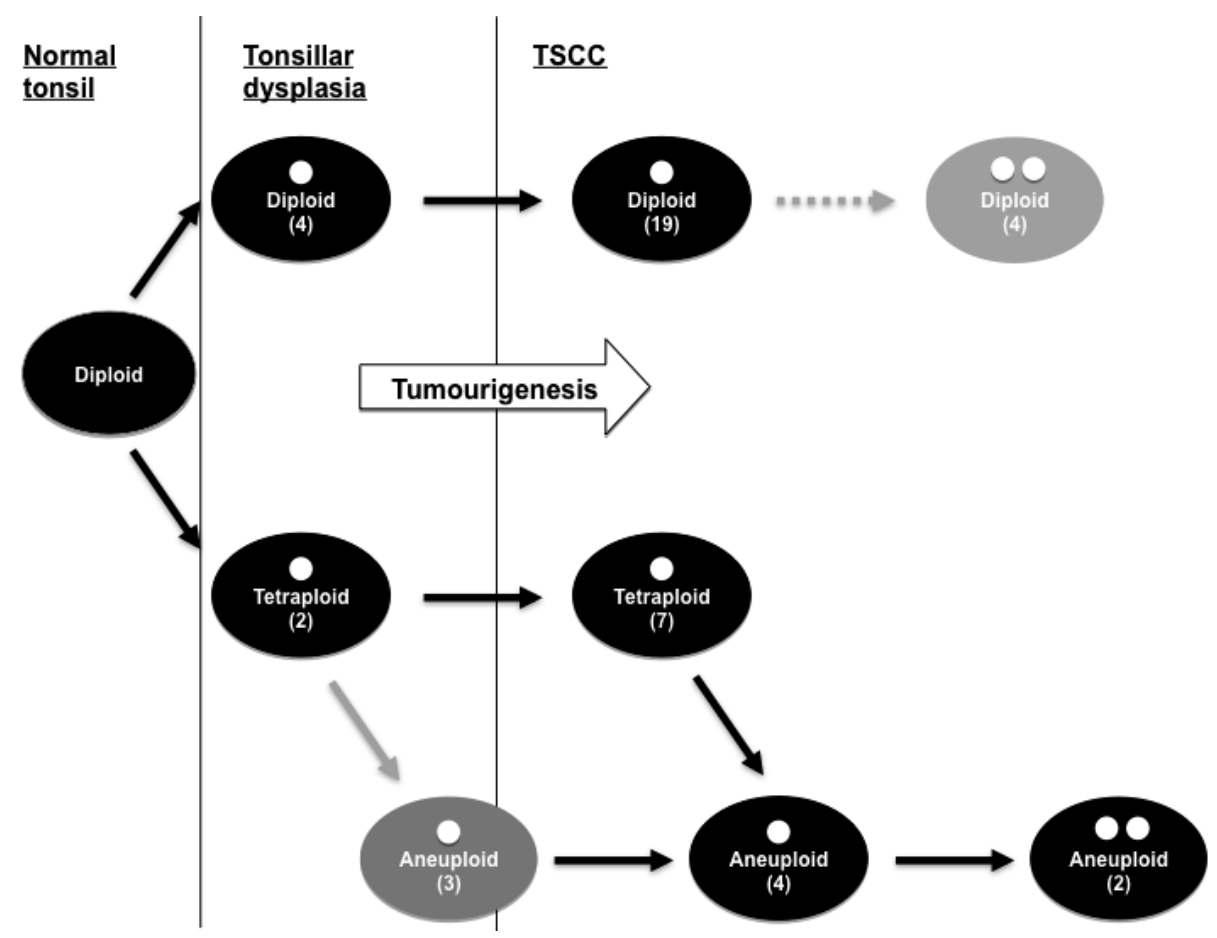

Figure 5.4 Hypothetical model for the development of HPV16-positive TSCC in relation to chromosome (in)stability, based on the findings of this study. An important event during tumourigenesis is HPV integration. Chromosome instability leading to tetraploidy or aneuploidy in the tumour is a key feature for survival.The most likely tumourigenic pathways are indicated in black, whereas less frequently occurring events are indicated in gray. The number of the HPV integration sites is indicated by the white dots. The number of observed cases is shown between brackets.

In smoking patients, more often single HPV16 integration signals in a chromosome unstable background are detected. These TSCC most likely develop from tetraploid or aneuploid premalignant lesions, induced by high HPV load and/or smoking-related toxins. During tumour progression these carcinomas undergo further genomic multiplication including the viral 
integration site. In conclusion, our data show that chromosome stability is more often found in HPV-positive TSCC than in HPV-negative tumours, and that chromosome instability is an indicator for unfavourable prognosis, particularly in the HPV-positive patient group.

Therefore, we recommend that ploidy-status should be taken into consideration as an additional prognostic factor in future risk models for cancer specific death, particularly in HPV-positive TSCC. 


\section{References}

1. Aguilera A, Gómez-González B. Genome instability: a mechanistic view of its causes and consequences. Nat Rev Genet 2008;9:204-17.

2. Abou-Elhamd KE, Habib TN. The flow cytometric analysis of premalignant and malignant lesions in head and neck squamous cell carcinoma. Oral Oncol 2007;43:366-72.

3. Mahmood JU, Suzuki K, Nomura T, Shingaki S, Nakajima T. The implication of DNA content and S-phase fraction in oral carcinomas with and without metastasis. Int J Oral Maxillofac Surg 1995;24:427-32.

4. Bockmuhl U, Wolf G, Schmidt S, Schwendel A, Jahnke V, Dietel M, Petersen I. Genomic alterations associated with malignancy in head and neck cancer. Head Neck 1998;20:145-51.

5. Califano J, van der Riet P, Westra W, Nawroz H, Clayman G, Piantadosi S, Corio R, Lee D, Greenberg B, Koch W, Sidransky D. Genetic progression model for head and neck cancer: implications for field cancerization. Cancer Res 1996;56: 2488-92.

6. Soder Al, Hopman AH, Ramaekers FC, Conradt C, Bosch FX. Distinct nonrandom patterns of chromosomal aberrations in the progression of squamous cell carcinomas of the head and neck. Cancer Res 1995;55:5030-7.

7. Morrison LE, Jacobson KK, Friedman M, Schroeder JW, Coon JS. Aberrant EGFR and chromosome 7 associate with outcome in laryngeal cancer. Laryngoscope 2005;115:1212-8.

8. Veltman JA, Bot FJ, Huynen FC, Ramaekers FC, Manni JJ, Hopman AH. Chromosome instability as an indicator of malignant progression in laryngeal mucosa. J Clin Oncol 2000;18:1644-51.

9. Bergshoeff VE, Hopman AH, Zwijnenberg IR, Ramaekers FC, Bot FJ, Kremer B, Manni JJ, Speel EJ. Chromosome instability in resection margins predicts recurrence of oral squamous cell carcinoma. J Pathol 2008;215:347-8.

10. Fleskens SJHM, Takes RP, Otte-Höller I, van Doesburg L, Smeets A, Speel E-JM, Slootweg PJ, van der Laak JAWM. Simultaneous assessment of DNA ploidy and biomarker expression in paraffin-embedded tissue sections. Histopathology 2010;57:14-26.

11. Taoudi Benchekroun $M$, Saintigny $P$, Thomas SM, El-Naggar AK, Papadimitrakopoulou V, Ren H, Lang W, Fan Y-H, Huang J, Feng L, Lee JJ, Kim ES, et al. Epidermal growth factor receptor expression and gene copy number in the risk of oral cancer. Cancer Prev Res (Phila) 2010;3:800-9.

12. Hafkamp HC, Manni JJ, Speel EJ. Role of human papillomavirus in the development of head and neck squamous cell carcinomas. Acta Otolaryngol 2004;124:520-6.

13. Weinberger PM, Yu Z, Haffty BG, Kowalski D, Harigopal M, Brandsma J, Sasaki C, Joe J, Camp RL, Rimm DL, Psyrri A. Molecular classification identifies a subset of human papillomavirus--associated oropharyngeal cancers with favorable prognosis. Journal of Clinical Oncology 2006;24:736-47.

14. Chen TM, Pecoraro G, Defendi V. Genetic analysis of in vitro progression of human papillomavirus-transfected human cervical cells. Cancer Res 1993;53:1167-71. 
15. Lace MJ, Anson JR, Klingelhutz AJ, Lee JH, Bossler AD, Haugen TH, Turek LP. Human Papillomavirus (HPV) Type 18 Induces Extended Growth in Primary Human Cervical, Tonsillar, or Foreskin Keratinocytes More Effectively than Other High-Risk Mucosal HPVs. Journal of Virology 2009;83:11784-94.

16. Pecoraro G, Lee M, Morgan D, Defendi V. Evolution of in vitro transformation and tumorigenesis of HPV16 and HPV18 immortalized primary cervical epithelial cells. Am J Pathol 1991;138:1-8.

17. Kim MS, Shin KH, Baek JH, Cherrick HM, Park NH. HPV-16, tobacco-specific Nnitrosamine, and $\mathrm{N}$-methyl-N'-nitro- $\mathrm{N}$-nitrosoguanidine in oral carcinogenesis. Cancer Res 1993;53:4811-6.

18. Gillison ML, Koch WM, Capone RB, Spafford M, Westra WH, Wu L, Zahurak ML, Daniel RW, Viglione M, Symer DE, Shah KV, Sidransky D. Evidence for a causal association between human papillomavirus and a subset of head and neck cancers. J Natl Cancer Inst 2000;92:709-20.

19. Hafkamp HC, Speel EJM, Haesevoets A, Bot FJ, Dinjens WNM, Ramaekers FCS, Hopman AHN, Manni JJ. A subset of head and neck squamous cell carcinomas exhibits integration of HPV 16/18 DNA and overexpression of p16INK4A and p53 in the absence of mutations in p53 exons 5-8. Int J Cancer 2003;107:394-400.

20. Klussmann JP, Weissenborn SJ, Wieland U, Dries V, Kolligs J, Jungehuelsing M, Eckel HE, Dienes HP, Pfister HJ, Fuchs PG. Prevalence, distribution, and viral load of human papillomavirus 16 DNA in tonsillar carcinomas. Cancer 2001;92: 2875-84.

21. Duensing S, Münger K. Mechanisms of genomic instability in human cancer: insights from studies with human papillomavirus oncoproteins. Int J Cancer 2004; 109:157-62.

22. Patel D, Incassati A, Wang N, McCance DJ. Human papillomavirus type 16 E6 and E7 cause polyploidy in human keratinocytes and up-regulation of G2-M-phase proteins. Cancer Res 2004;64:1299-306.

23. White AE, Livanos EM, TIsty TD. Differential disruption of genomic integrity and cell cycle regulation in normal human fibroblasts by the HPV oncoproteins. Genes \& Development 1994;8:666-77.

24. Southern SA, Noya F, Meyers C, Broker TR, Chow LT, Herrington CS. Tetrasomy is induced by human papillomavirus type 18 E7 gene expression in keratinocyte raft cultures. Cancer Res 2001;61:4858-63.

25. Xiong Y, Kuppuswamy D, Li Y, Livanos EM, Hixon M, White A, Beach D, TIsty TD. Alteration of cell cycle kinase complexes in human papillomavirus E6- and E7expressing fibroblasts precedes neoplastic transformation. Journal of Virology 1996;70:999-1008.

26. Hopman AHN, Smedts F, Dignef W, Ummelen M, Sonke G, Mravunac M, Vooijs GP, Speel E-JM, Ramaekers FCS. Transition of high-grade cervical intraepithelial neoplasia to micro-invasive carcinoma is characterized by integration of HPV 16/18 and numerical chromosome abnormalities. J Pathol 2004;202:23-33.

27. Hopman A, Theelen W, Hommelberg P, Kamps M, Herrington C, Morrison L, Speel E-J, Smedts F, Ramaekers F. Genomic integration of oncogenic HPV and gain of the human telomerase geneTERC at 3q26 are strongly associated events in the progression of uterine cervical dysplasia to invasive cancer. $J$ Pathol 2006;210:412-9.

28. Hausen zur H. Papillomaviruses and cancer: from basic studies to clinical application. Nat Rev Cancer 2002;2:342-50. 
29. Andl T, Kahn T, Pfuhl A, Nicola T, Erber R, Conradt C, Klein W, Helbig M, Dietz A, Weidauer $\mathrm{H}$, Bosch $\mathrm{FX}$. Etiological involvement of oncogenic human papillomavirus in tonsillar squamous cell carcinomas lacking retinoblastoma cell cycle control. Cancer Res 1998;58:5-13.

30. D'Souza G, Kreimer AR, Viscidi R, Pawlita M, Fakhry C, Koch WM, Westra WH, Gillison ML. Case-control study of human papillomavirus and oropharyngeal cancer. N Engl J Med 2007;356:1944-56.

31. Hafkamp HC, Manni JJ, Haesevoets A, Voogd AC, Schepers M, Bot FJ, Hopman AHN, Ramaekers FCS, Speel E-JM. Marked differences in survival rate between smokers and nonsmokers with HPV 16-associated tonsillar carcinomas. Int $J$ Cancer 2008;122:2656-64.

32. Mellin H, Friesland $S$, Lewensohn R, Dalianis T, Munck-Wikland E. Human papillomavirus (HPV) DNA in tonsillar cancer: clinical correlates, risk of relapse, and survival. Int J Cancer 2000;89:300-4.

33. Hafkamp HC, Mooren JJ, Claessen SM, Klingenberg B, Voogd AC, Bot FJ, Klussmann JP, Hopman AH, Manni JJ, Kremer B, Ramaekers FC, Speel EJ. P21 Cip1/WAF1 expression is strongly associated with HPV-positive tonsillar carcinoma and a favorable prognosis. Mod Pathol 2009;22:686-98.

34. Shanmugaratnam S. Histologic typing of tumors of the upper respiratory tract and ear. Geneva (Switserland): World Health Organization, 1991.

35. Hopman AH, Kamps MA, Speel EJ, Schapers RF, Sauter G, Ramaekers FC. Identification of chromosome 9 alterations and p53 accumulation in isolated carcinoma in situ of the urinary bladder versus carcinoma in situ associated with carcinoma. Am J Pathol 2002;161:1119-25.

36. Marur S, D'Souza G, Westra WH, Forastiere AA. HPV-associated head and neck cancer: a virus-related cancer epidemic. The Lancet Oncology 2010;11:781-9.

37. Braakhuis BJ, Snijders PJ, Keune WJ, Meijer CJ, Ruijter-Schippers HJ, Leemans $\mathrm{CR}$, Brakenhoff RH. Genetic patterns in head and neck cancers that contain or lack transcriptionally active human papillomavirus. J Natl Cancer Inst 2004;96: 998-1006.

38. Agrawal N, Frederick MJ, Pickering CR, Bettegowda C, Chang K, Li RJ, Fakhry C, Xie TX, Zhang J, Wang J, Zhang N, El-Naggar AK, et al. Exome Sequencing of Head and Neck Squamous Cell Carcinoma Reveals Inactivating Mutations in NOTCH1. Science 2011;333:1154-7.

39. Heselmeyer K, Schrock E, Manoir du S, Blegen H, Shah K, Steinbeck R, Auer G, Ried T. Gain of chromosome $3 q$ defines the transition from severe dysplasia to invasive carcinoma of the uterine cervix. Proc Natl Acad Sci U S A 1996;93: 479-84.

40. Klussmann JP, Mooren JJ, Lehnen M, Claessen SMH, Stenner M, Huebbers CU, Weissenborn SJ, Wedemeyer I, Preuss SF, Straetmans JMJAA, Manni JJ, Hopman AHN, et al. Genetic Signatures of HPV-related and Unrelated Oropharyngeal Carcinoma and Their Prognostic Implications. Clinical Cancer Research 2009;15:1779-86.

41. Jung AC, Briolat J, Millon R, de Reyniès A, Rickman D, Thomas E, Abecassis J, Clavel C, Wasylyk B. Biological and clinical relevance of transcriptionally active human papillomavirus (HPV) infection in oropharynx squamous cell carcinoma. Int J Cancer 2010;126:1882-94. 
42. Sartor MA, Dolinoy DC, Jones TR, Colacino JA, Prince ME, Carey TE, Rozek LS. Genome-wide methylation and expression differences in HPV(+) and HPV(-) squamous cell carcinoma cell lines are consistent with divergent mechanisms of carcinogenesis. Epigenetics 2011;6:777-87.

43. Yang N, Nijhuis ER, Volders HH, Eijsink JJ, Lendvai A, Zhang B, Hollema H, Schuuring E, Wisman GB, van der Zee AG. Gene promoter methylation patterns throughout the process of cervical carcinogenesis. Cell Oncol 2010;32:131-43.

44. Stenner M, Yosef B, Huebbers CU, Preuss SF, Dienes H-P, Speel E-JM, Odenthal $M$, Klussmann JP. Nuclear translocation of $\beta$-catenin and decreased expression of epithelial cadherin in human papillomavirus-positive tonsillar cancer: an early event in human papillomavirus-related tumour progression? Histopathology 2011;58:1117-26.

45. Tammela T, Alitalo K. Lymphangiogenesis: Molecular mechanisms and future promise. Cell 2010;140:460-76.

46. Southern SA, Evans MF, Herrington CS. Basal cell tetrasomy in low-grade cervical squamous intraepithelial lesions infected with high-risk human papillomaviruses. Cancer Res 1997;57:4210-3.

47. Kumar B, Cordell KG, Lee JS, Worden FP, Prince ME, Tran HH, Wolf GT, Urba SG, Chepeha DB, Teknos TN, Eisbruch A, Tsien Cl, et al. EGFR, p16, HPV Titer, $\mathrm{Bcl}-\mathrm{xL}$ and $\mathrm{p53}$, sex, and smoking as indicators of response to therapy and survival in oropharyngeal cancer. Journal of Clinical Oncology 2008;26:3128-37.

48. Ang KK, Harris J, Wheeler R, Weber R, Rosenthal DI, Nguyen-Tân PF, Westra $\mathrm{WH}$, Chung $\mathrm{CH}$, Jordan RC, Lu C, Kim H, Axelrod R, et al. Human papillomavirus and survival of patients with oropharyngeal cancer. N Engl J Med 2010;363:24-35.

49. Reimers N, Kasper HU, Weissenborn SJ, Stutzer H, Preuss SF, Hoffmann TK, Speel EJ, Dienes HP, Pfister HJ, Guntinas-Lichius O, Klussmann JP. Combined analysis of HPV-DNA, p16 and EGFR expression to predict prognosis in oropharyngeal cancer. Int J Cancer 2007;120:1731-8.

50. Egelmeer AGTM, Velazquez ER, de Jong JMA, Oberije C, Geussens Y, Nuyts S, Kremer B, Rietveld D, Leemans CR, de Jong MC, Rasch C, Hoebers F, et al. Development and validation of a nomogram for prediction of survival and local control in laryngeal carcinoma patients treated with radiotherapy alone: a cohort study based on 994 patients. Radiother Oncol 2011;100:108-15.

51. Maxwell JH, Kumar B, Feng FY, Worden FP, Lee JS, Eisbruch A, Wolf GT, Prince ME, Moyer JS, Teknos TN, Chepeha DB, McHugh JB, et al. Tobacco use in human papillomavirus-positive advanced oropharynx cancer patients related to increased risk of distant metastases and tumor recurrence. Clin Cancer Res 2010;16: 1226-35. 


\section{Chapter}

EGFR EXPRESSION PREDICTS UNFAVOURABLE SURVIVAL IN ADVANCED HPV-POSITIVE OROPHARYNGEAL CANCER TREATED WITH CHEMORADIATION

J. Pramana*, Jeroen J Mooren*, MC de Jong, MWM van den Brekel, ML van Velthuysen, T Pirens,

Annick Haesevoets, Bernd Kremer, AC Begg,

Ernst-Jan M Speel

* These authors contributed equally to this study as first authors

Submitted for publication 


\section{Abstract}

\section{Objective}

About half of the patients with a head and neck squamous cell carcinoma have advanced disease. In these cases chemoradiation can achieve locoregional control rates of on average $65 \%$. Recent literature suggests that HPV-detection might subdivide these cases, particularly those originating from the pharynx, into groups with a different prognosis. This separation can even be stronger by taking cigarette smoking and high EGFR expression into consideration as poor prognosticators. We studied the incidence and predictive value of HPV-presence in a series of squamous cell carcinomas presented in the oropharynx (OPSCC) and hypopharynx (HPSCC), all treated with chemoradiation therapy. Furthermore, we tested the hypothesis that high EGFR expression and/ or cigarette smoking within HPV-positive tumours have an influence on patient survival.

\section{Material and methods}

Advanced OPSCC $(n=111)$ and HPSCC $(n=46)$ patients, treated with concurrent radiotherapy and chemotherapy (cisplatin) within phase II and randomized phase III trials at the Netherlands Cancer Institute between 1997 and 2004, were included. Tissue microarrays of tumour specimens were subjected to $\mathrm{p} 16^{\text {INK4A }}$ and EGFRimmunohistochemistry and HPV16-specific FISH-analysis. Whole tissue sections were used for DNA isolation and HPV-specific PCR in 10 cases. Endpoints included locoregional recurrence free survival, distant metastases free survival and overall and disease free survival.

\section{Results}

Out of 111 OPSCC, 37 (33\%) were p16 ${ }^{\text {INK4A }}$ positive, of which 35 were HPV16- and 2 HPV33-positive. Kaplan-Meier analyses revealed that HPV-positivity was associated with less locoregional recurrences (0.039), less distant metastases $(p=0.012)$ and a more favourable overall and disease free survival $(p=0.001)$. Within the HPV-positive group, EGFR immunopositive tumours had a worse survival than EGFR negative cases $(p=0.02)$, and 9 out of 31 smokers developed recurrent diseases versus 1 out of 6 nonsmokers (no significant difference). Only 1 HPSCC (2\%) was HPV16-positive.

\section{Conclusion}

$\mathrm{P} 16^{\mathrm{INK} 4 \mathrm{~A}}$ is a good surrogate marker for high-risk HPV-positive pharyngeal cancer. HPV-presence in advanced OPSCC, all treated with a similar treatment modality, predicts decreased risk of locoregional recurrences, distant metastases and a favourable disease free survival. Interestingly, EGFR-immunopositivity was an unfavourable predictive factor in HPV-positive tumours. 


\section{Introduction}

Head and neck squamous cell carcinoma (HNSCC) is the $7^{\text {th }}$ most common cancer in the world with more than 630,000 new cases and around 350,000 disease related deaths in 2008. ${ }^{1}$ At presentation half of these patients have advanced disease. ${ }^{2}$ In cases with advanced oropharyngeal and hypopharyngeal cancer chemoradiation is the most frequently used treatment, with locoregional control rates of around $65 \%$ after two years. ${ }^{3}$

A subgroup of HNSCC, originating from the oropharynx, is etiologically related to prolonged exposure to cigarette smoking and alcohol intake, but can also be induced by high-risk (HR) human papillomavirus (HPV) infection, particularly HPV-type $16{ }^{4-6}$ The latter subgroup is the only type of HNSCC with a rising age adjusted incidence in recent years. ${ }^{7,8}$ Furthermore, patients with an HPV-positive tumour have a much better prognosis than patients with a smoking/tobacco induced tumour., ${ }^{5,910}$ Within the HPV-positive patient group, smoking is an indicator of unfavourable prognosis. ${ }^{10,11}$

The HPV-positive tumours are now considered to be a separate entity on basis of both clinical and molecular factors. ${ }^{12}$ For example, these tumours often have low $\mathrm{T}$-stages and higher $\mathrm{N}$-stages at presentation and are associated with less smoking/ alcohol consumption. By using these parameters, a prognostic riskmodel has been put forward to subdivide OPSCC patients in 3 risk-groups. ${ }^{11}$

On the molecular level, HPV-positive tumours show deregulation of the cellular p53 and pRb pathways by the functional activity of the viral oncoproteins E6 and E7, respectively. As a consequence, they usually lack classical gene mutations found in the HPV-negative tumours, such as those in p53 and p16 ${ }^{\text {INK4A }}{ }^{13,14}$ Moreover, high expression of the epidermal growth factor receptor (EGFR) is usually absent. ${ }^{15-17}$ If present in HPV-positive tumours, patients may show an unfavourable survival when treated with multimodal therapy. ${ }^{15}$

A number of chemoradiation trials have been retrospectively analysed for HPV-presence and in all studies HPV-positivity was found to be a favourable prognostic factor. ${ }^{18}$ Some studies analysed in addition EGFR expression with different outcomes in relation to survival. ${ }^{16,19}$

The aim of the present study was to analyse the incidence and predictive value of HPV-presence, $\mathrm{p} 16^{\mathrm{INK} 4 \mathrm{~A}}$ and EGFR (over)expression, as well as clinical factors in a series of patients with squamous cell carcinoma originating from the oropharynx (OPSSC) and hypopharynx (HPSCC), treated with the same modality, i.e. concurrent radiotherapy and chemotherapy (cisplatin) at the Netherlands Cancer Institute [20]. Data were correlated with survival outcomes, including locoregional control, distant metastasis, overall survival (OS) and disease free survival (DFS). 


\section{Patients and methods}

\section{Study population}

We selected tissue material from 157 patients, diagnosed between 1997 and 2004 and treated within phase II and randomized phase III trials at the Netherlands Cancer Institute. ${ }^{3}$ These included 111 patients with an OPSCC and 46 with a HPSCC. Patient material was used according to the Code for Proper Secondary Use of Human Tissue (Federation of Medical Scientific Societies, The Netherlands; 2003). Patient data were extracted from retrospective chart review, including age at diagnosis, gender, smoking behaviour, TNM stage and clinical follow-up data.

Overall follow-up time ranged from 3 months to 77 months with a mean of 24 months. The follow-up time to locoregional recurrence ranged from 1 month to 13 months (mean: 6 months), time to distant metastases from 1 month to 57 months (mean: 9 months) and time to disease recurrence from 1 month to 57 months (mean: 13 months).

Table 1 provides demographic and clinical features of the 111 OPSCC patients included in this study. Age at diagnosis ranged from 39 to 85 years (mean 58 years), 79 patients were male and 32 patients were female. Most of these patients presented with advanced (T3 and T4) pharyngeal tumours and had lymph node metastases at time of diagnosis. Smoking data were available for 108 patients. One hundred (93\%) of the 108 patients were smokers (>1 cigarette, pipe, and/or cigar per day). Two out of the 8 non-smokers were former smokers (quit smoking $>10$ years before diagnosis).

All patients were treated with concurrent radiotherapy and chemotherapy (cisplatin) in a phase II and randomised phase III trial with intention to cure. All patients were irradiated with a total dose of 46 Gy to elective lymph nodes and 70 Gy to the affected areas, given in 2 Gy daily fractions, 5 times per week. During radiotherapy, patients received either 3 courses of high dose cisplatin: $100 \mathrm{mg} / \mathrm{m}^{2}$ body surface intravenously (IV), 4 courses of $150 \mathrm{mg} / \mathrm{m}^{2}$ body surface given intra-arterially (IA) or a daily low dose of cisplatin $\left(20 \times 6 \mathrm{mg} / \mathrm{m}^{2}\right.$ body surface). Recurrences were defined as histologically confirmed local recurrences or clinically progressive disease. In the neck, a regional recurrence was defined as vital tumour cells in a neck dissection specimen or clinically progressive disease. Necrosis in a lymph node in the neck dissection specimen without vital tumour cells was not considered a regional recurrence. If there was no evidence for recurrent disease, patients were considered to be cured. Following primary treatment, 16 out of 111 patients (23\%) developed a locoregional recurrence and 41 out of 111 (37\%) a disease recurrence (locoregional or distant metastasis). Seventy patients (63\%) remained disease free after treatment. 
Clinical and molecular data for the HPSCC patient group are summarized in supplementary Table 6.1.

Table 6.1 Clinical and molecular characteristics of OPSCC, including HPV-status.

\begin{tabular}{|c|c|c|c|}
\hline Characteristic & $\mathrm{HPV}+(\%)$ & HPV - (\%) & $\begin{array}{c}\text { p-value (Fisher's } \\
\text { exact) }\end{array}$ \\
\hline \multicolumn{4}{|l|}{ Gender } \\
\hline Male & $31(84 \%)$ & $48(65 \%)$ & $p=0.046$ \\
\hline Female & $6(16 \%)$ & $26(35 \%)$ & \\
\hline \multicolumn{4}{|l|}{ Age at diagnosis } \\
\hline$>60$ & $23(62 \%)$ & $43(58 \%)$ & NS \\
\hline$<60$ & $14(38 \%)$ & $31(42 \%)$ & \\
\hline \multicolumn{4}{|l|}{ T-stage } \\
\hline T2 & $1(3 \%)$ & $4(5 \%)$ & NS \\
\hline T3 & $12(32 \%)$ & $27(36 \%)$ & \\
\hline T4 & $24(65 \%)$ & $43(59 \%)$ & \\
\hline \multicolumn{4}{|l|}{$\mathrm{N}$-stage } \\
\hline No & $8(21 \%)$ & $12(16 \%)$ & NS \\
\hline $\mathrm{N} 1$ & $5(14 \%)$ & $7(10 \%)$ & \\
\hline N2 & $20(54 \%)$ & $43(58 \%)$ & \\
\hline N3 & $4(11 \%)$ & $12(16 \%)$ & \\
\hline \multicolumn{4}{|l|}{ M-stage } \\
\hline Mo & $31(84 \%)$ & $56(76 \%)$ & $p=0.46$ \\
\hline M1 & $6(16 \%)$ & $18(24 \%)$ & \\
\hline \multicolumn{4}{|l|}{ Locoregional recurrence } \\
\hline Yes & $5(14 \%)$ & $21(28 \%)$ & NS \\
\hline No & $32(86 \%)$ & $53(72 \%)$ & \\
\hline \multicolumn{4}{|l|}{ Disease recurrence } \\
\hline Yes & $11(30 \%)$ & $30(40 \%)$ & NS \\
\hline No & $26(70 \%)$ & $44(60 \%)$ & \\
\hline \multicolumn{4}{|l|}{$\mathrm{P} 16^{\mathrm{INK} 4 \mathrm{~A}}$} \\
\hline Positive & $37(100 \%)$ & 0 & $p<0.0001$ \\
\hline Negative & 0 & $74(100 \%)$ & \\
\hline \multicolumn{4}{|l|}{ EGFR } \\
\hline Positive & $27(73 \%)$ & $47(64 \%)$ & NS \\
\hline Negative & $10(27 \%)$ & $27(36 \%)$ & \\
\hline \multicolumn{4}{|l|}{ Smoking } \\
\hline Yes & $31(84 \%)$ & $69(97 \%)$ & $p=0.02$ \\
\hline $\begin{array}{c}\text { No } \\
\text { (3 patients no data) }\end{array}$ & $6(16 \%)$ & $2(3 \%)$ & \\
\hline
\end{tabular}

\section{Tissue Microarray}

Tissue Microarrays (TMAs) were constructed as described by Chen et al. ${ }^{21}$ Briefly, from every routinely fixed paraffin embedded tumour block (tissues collected prior to treatment) a tissue section was stained with $H$ \& $E$ to guide the sampling of morphologically representative regions of the tumour. To construct the TMA, 3 core tissue biopsy specimens (diameter: $0.6 \mathrm{~mm}$ ) from selected regions of the donor block were taken and brought into a new recipient paraffin block using a manual tissue arrayer (Beecher Instruments, 
Silver Spring, MD, USA). Each TMA block contained a maximum of 168 punches. Five $\mu \mathrm{m}$ tissue sections were cut with a microtome using an adhesive-coated tape sectioning system (Instramedics Hackensack, NJ) of which one was stained with $\mathrm{H} \& \mathrm{E}$ to verify histology.

\section{P16 ${ }^{\text {INK } 4 A}$ and EGFR immunohistochemistry}

Immunostaining with primary antibodies was performed using standard methodologies previously described. ${ }^{21,22}$ In short, TMA sections were deparaffinized and subsequently heated in a microwave in $0.1 \mathrm{M}$ Citrate $\mathrm{pH} 6.0$ ( $\mathrm{p} 16^{\mathrm{INK} 4 \mathrm{~A}}$ staining) or treated with pepsin at $37^{\circ} \mathrm{C}$ (EGFR staining) for antigen retrieval. After blocking endogenous peroxidases with $0.3 \% \mathrm{H}_{2} \mathrm{O}_{2}$ the sections were incubated with primary mouse monoclonal antibodies directed against EGFR (clone 111.6; diluted 1:100, Neomarkers, Freemont, CA, US) or p16 ${ }^{\text {INK } 4 A}$ (clone 16P04; diluted 1:500, Neomarkers) diluted in 1\% BSA-PBS.

Secondary rabbit anti-mouse peroxidase antibodies were used to detect the primary antibodies. Peroxidase activity was visualized by $\mathrm{H}_{2} \mathrm{O}_{2} / 3.3$ ' diaminobenzidine tetrachloride as a substrate and slides were counterstained with hematoxylin. Stainings were considered positive for $\mathrm{p} 16^{\mathrm{INK} 4 \mathrm{~A}}$ if more than $70 \%$ of the nuclei and cytoplasm stained strongly positive and for EGFR if more than $50 \%$ of tumour cell membranes, with or without the cytoplasm, completely stained positive. ${ }^{15}$ The scoring was performed by 2 investigators (J.P., E-J.S.).

\section{FISH analysis}

FISH for the detection of HPV16 was performed on 5- $\mu$ m thick TMA sections from all patients as described previously. ${ }^{13}$ Briefly, sections were deparaffinized, pretreated with $85 \%$ formic acid $0.3 \% \mathrm{H} 2 \mathrm{O} 2,1 \mathrm{M} \mathrm{NaSCN}$ and $4 \mathrm{mg} / \mathrm{ml}$ pepsin, post-fixed in $1 \%$ formaldehyde in PBS, dehydrated in an ethanol series and hybridized with digoxigenin-labeled HPV16-specific probes (PanPath, Budel, The Netherlands) according to the manufacturer's instructions. After hybridization the preparations were washed stringently in $50 \%$ formamide, $2 \times \mathrm{SSC}$ at $42^{\circ} \mathrm{C}(2$ times $5 \mathrm{~min})$. The probes were detected by application of mouse anti-digoxin (Sigma, St. Louis, MO), peroxidaseconjugated rabbit anti-mouse and peroxidase-conjugated swine anti-rabbit antibodies (both Dako A/S), and visualized by a peroxidase reaction using rhodamine-labeled tyramide. ${ }^{23}$ Preparations were mounted in Vectashield (Vector Laboratories, Burlingame, CA) containing 4,6-diamidino-2-phenyl indole (DAPI; Sigma: $0.2 \mathrm{~g} / \mathrm{ml}$ ). Microscope images were recorded with the Metasystems Image Pro System (black and white CCD camera; Sandhausen, Germany) mounted on top of a Leica DM-RE fluorescence microscope equipped with DAPI and rhodamine filters.

Evaluation of nuclear hybridization signals was performed by 2 investigators (J.P., E-J.S.) according to the criteria described by Mooren et al., ${ }^{24}$ i.e. nuclear 
punctate signals were considered to indicate integrated HPV DNA and diffuse signals to indicate episomal HPV DNA. Also a granular FISH pattern, defined as the presence of several nuclear signals varying significantly in size and intensity, was observed in a few cases, which may indicate a combination of viral integration and episomal DNA and/or viral RNA. Controls included hybridizations on HPV16-positive formaldehyde-fixed, paraffin-embedded tissues of known human uterine cervical and head and neck (pre)malignancies. Negative controls consisted of HPV PCR- and FISH-negative tissue sections and hybridizations omitting the viral probe.

\section{HPV-specific PCR and enzyme-immunoassay typing}

PCR analysis was performed to identify HPV-types in $2 \mathrm{p} 16^{\mathrm{INK} 4 \mathrm{~A}}$ positive, HPV16 FISH-negative tumours. Additionaly, 4 HPV16-positive and 4 HPV16negative cases were analysed as controls. Genomic DNA was extracted from 5-10 five $\mu \mathrm{m}$-thick tissue sections of biopsies (collected prior to treatment), using the QIAamp DNA mini kit (Qiagen, Westburg, Leusden, The Netherlands). RAG1 gene PCR, according to the protocol of the Department of Pathology of the Maastricht University Medical Center, was performed with all samples to demonstrate that they contained sufficient DNA of adequate quality and size (minimal $200 \mathrm{bp}$ ).

HPV16-specific PCR was performed according to Baay et al. ${ }^{25}$ Negative controls, consisting of water or human placental DNA instead of patient samples, were included in each PCR run. A general primer GP5+/6+ PCR (150 bp product) for HPV was used; PCR products were separated on $2 \%$ agarose gels and visualized by Sybr Safe staining. For HPV-typing biotinylated PCR products were hybridized with 37 type-specific digoxigenin-labeled oligonucleotide probes in an enzyme-immunoassay (EIA). ${ }^{26}$

\section{Statistical analysis}

Clinical and molecular parameters were correlated with HPV-status using cross-tabulations and the two-tailed Fisher exact test and/or Chi-square test. We regarded a $p$-value $\leq 0.05$ as significant. The Kaplan-Meier method was used to calculate survival curves. Overall survival (OS) was calculated from the date of diagnosis until date of patient's death or until the last date the patient was known to be alive. Disease-free survival (DFS) was calculated from the date of diagnosis until the date of recurrence (local, regional or distant, whichever occurred first). Patients without recurrence were censored at the date of the last follow-up or the date of death. Locoregional recurrence free survival (LRFS) and metastases free survival (MFS) were calculated from the date of diagnosis until the date of locoregional recurrence and the date of metastases detection, respectively. 
The statistical significance of differences between survival times was determined by the log rank test in univariate analysis. Hazard ratios were calculated using Cox regression analysis. We used the SPSS Base System version 20.0 for all calculations.

\section{Results}

\section{Correlation between HPV-status, immunostainings and clinical factors}

Of the 46 HPSCCs only $1(2 \%)$ showed a strong nuclear and cytoplasmic p $16^{\text {INK4A }}$ immunostaining and FISH analysis identified HPV16 in the cell nuclei (see Supplementary Table S6.1). This tumour originated from the pyriform sinus. In contrast, 37 of 111 (33\%) OPSCCs showed strong p16 INK4A $^{\text {In }}$ immunostaining in more than $70 \%$ of tumour cells (Figure $6.1 \mathrm{~A}$ ). Thirty-five of these 37 cases contained HR-HPV16 assessed by FISH analysis; 31 showed punctate (Figure 6.1B), 2 granular and 2 diffuse FISH signals. The two $\mathrm{p} 16^{\mathrm{INK} 4 \mathrm{~A}}$ positive/ HPV16 FISH-negative cases proved to contain HPV33 DNA upon PCR analyses. Thus, all $\mathrm{p} 16^{\mathrm{INK} 4 \mathrm{~A}}$ positive cases harboured HR-HPV in this study (Table 6.1).
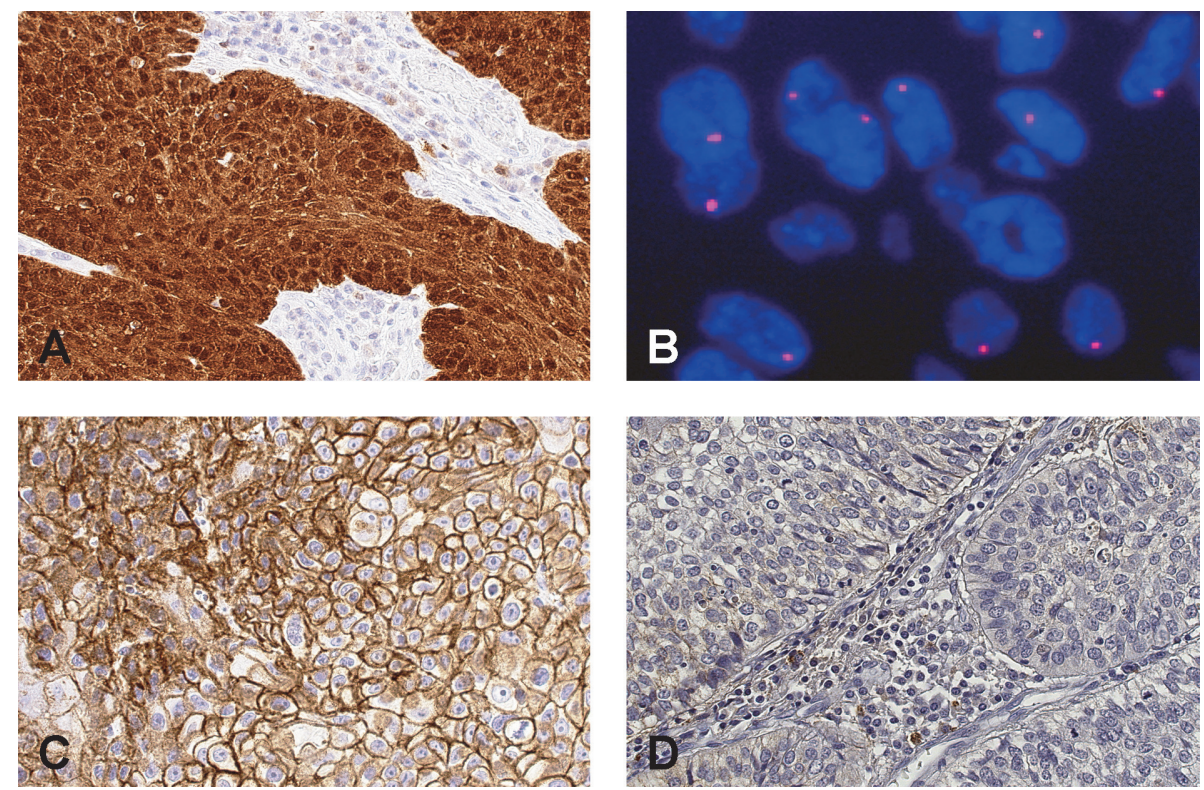

Figure 6.1 Representative examples of (A) an HPV16-positive OPSCC with a strong nuclear and cytoplasmic $\mathrm{p} 16^{\mathrm{INK} 4 \mathrm{~A}}$ immunohistochemical staining pattern in all tumour cells, (B) an HPV16-positive OPSCC with a punctated FISH pattern, (C) an HPV-negative OPSCC with strong EGFR immunostaining of the tumour cell membranes and (D) an HPVpositive, EGFR negative OPSCC. 
The HPV-positive OPSCC group showed a significantly higher male-female ratio $(p=0.046)$ and these patients smoked significantly less than patients with an HPV-negative tumour $(p=0.002)$. There were no significant differences in age at first diagnosis or the $\mathrm{T}$ - and $\mathrm{N}$-status between the 2 patient groups.

Twenty-seven out of 37 (73\%) HPV-positive OPSCCs were EGFR positive, compared to 47 out of $74(64 \%)$ in the HPV-negative group (Figure 6.1C, no significant difference). Six out of the 8 non- or former-smokers were found in the HPV-positive group, of which only 1 was EGFR negative. From the 2 nonsmokers in the HPV-negative group 1 tumour was EGFR negative and 1 EGFR positive.

\section{Survival}

OS and DFS between OPSCC and HPSCC were not significantly different (data not shown).

Within the OPSCC group we correlated HPV-status, EGFR expression and smoking-behaviour with OS, DFS, LRFS and MFS to determine their role as predictive markers and indicators of prognosis. Results are presented in Figure 6.2 and Figure 6.3.
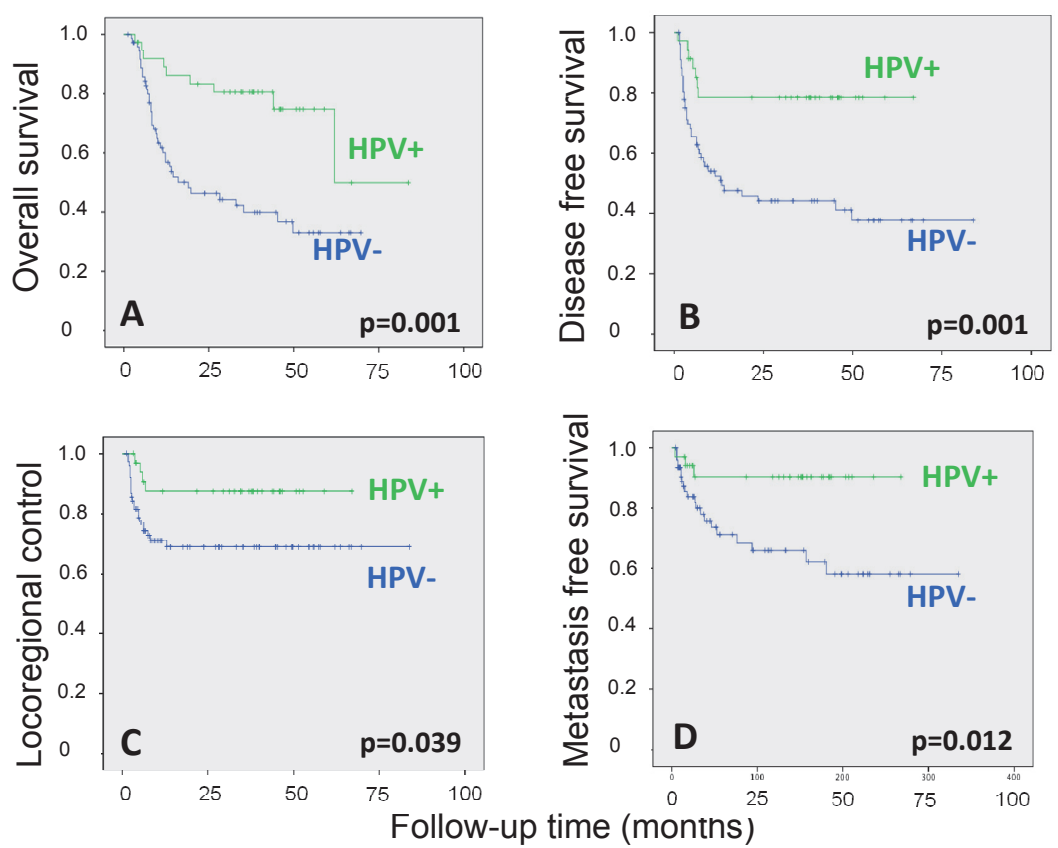

Figure 6.2 Kaplan Meier curves according to HPV-status for (A) overall survival $(H R=0.27$, $95 \% \mathrm{Cl}=0.12-0.62), \quad$ (B) disease free survival ( $\mathrm{HR}=0.29,95 \% \mathrm{Cl}=0.13-0.65)$, (C) locoregional control (HR=0.241, 95\% Cl=0.072-0.811) and (D) metastasis free survival $(\mathrm{HR}=0.337,95 \% \mathrm{Cl}=0.116-0.981)$ in 111 OPSCC. 
HPV-positive OPSCCs have a significant favourable OS, DFS, LRFS and MFS compared to HPV-negative tumours (Figure 6.2). The 5 -year OS was $76 \%$ for the HPV-positive OPSCC group and $45 \%$ for the HPV-negative group $(\mathrm{HR}=0.27,95 \% \mathrm{Cl}=0.12-0.62)$ (Figure 6.2A). The DFS after 5 years was $79 \%$ for patients with an HPV-positive carcinoma and $46 \%$ for patients with an $\mathrm{HPV}$-negative carcinoma ( $\mathrm{HR}=0.29, \quad 95 \% \mathrm{Cl}=0.13-0.65)$ (Figure 6.2B). Furthermore patients with an HPV-positive tumour developed significantly less locoregional recurrences and distant metastases than patients with an HPV-negative tumour $(\mathrm{HR}=0.241,95 \% \mathrm{Cl}=0.072-0.811$, and $\mathrm{HR}=0.337,95 \%$ $\mathrm{Cl}=0.116-0.981$, respectively) (Figure $6.2 \mathrm{C}$ and 6.2D).

No associations were found between EGFR expression and patient survival in the whole OPSCC group. In the OS analyses, however, after $\sim 35$ months a difference between EGFR positive and -negative tumours could be observed (Figure 6.3A). Therefore, we also assessed the correlation between EGFR expression and survival in OPSCC, stratified for HPV-status. This revealed no association between EGFR expression and survival in the HPV-negative group (Figure 6.3B), but did reveal that EGFR overexpression was significantly associated with an unfavourable OS and DFS in the HPV-positive OPSCC group ( $p=0.02$ and $p=0.036$, Figure $6.3 \mathrm{C}$ and Figure $6.3 \mathrm{D}$, respectively). Both in LRFS and MFS analyses similar curves can be seen, although not reaching significance (data not shown).
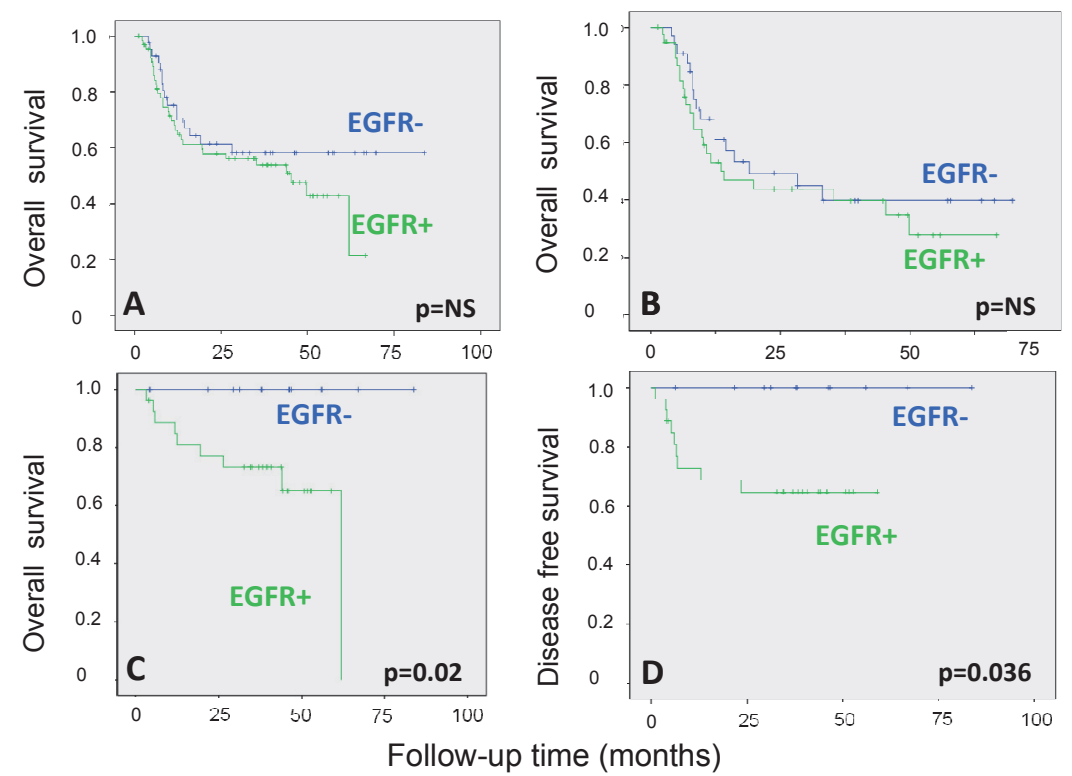

Figure 6.3 Kaplan Meier curves according to EGFR status for overall survival in (A) all 111 OPSCC, (B) 74 HPV-negative OPSCC and (C) 37 HPV-positive OPSCC; and for (D) disease free survival in $37 \mathrm{HPV}$-positive OPSCC. 
Eight patients were non-smokers in the OPSCC group. No association was found between smoking-status and patient survival, also after stratification for HPV-status. Nevertheless, a favourable trend could be observed for nonsmokers in OS and MFS analyses (Supplementary Figure S6.1A and S6.1B).

\section{Discussion}

In contrast to the decreases in incidence of most HNSCC over the last decade, the occurrence of OPSCC is increasing worldwide, which has been particularly attributed to HPV. ${ }^{7,8}$ Survival is markedly better for patients with HPV-positive OPSCC, but appears to be influenced by several additional parameters, including smoking behaviour and, on the molecular level EGFR gene expression. ${ }^{10,16}$ The goal of the present study was to analyse the incidence and predictive value of HPV-presence, $\mathrm{p} 16^{\text {INK4A }}$ and EGFR protein (over)expression, as well as clinical factors in a series of patients with OPSSC and HPSCC, all treated with a similar treatment modality, i.e. concurrent radiotherapy and chemotherapy (cisplatin). We found an incidence of HR-HPV in OPSCC and HPSCC of $33 \%$ and $2 \%$, respectively. In the OPSCC group HPV-positivity was associated with the occurrence of less locoregional recurrences, less distant metastases and a more favourable overall and disease free survival. Within the HPV-positive tumours, EGFR immunopositivity was associated with a significant unfavourable survival, and recurrent disease appeared to be more often present in smokers.

The observed prevalence of $33 \%$ HPV-positivity in our study with OPSCC specimens obtained between 1997 and 2004 is in accordance with other studies using material of patients diagnosed in approximately the same time period. ${ }^{6,22,27}$ Recent studies show increasing incidence-figures of HPV-related OPSCC over the last decades, for example Marur et al. ${ }^{7}$ describe a rise in incidence of OPSCC (most likely to be HPV-associated) by $1.3 \%$ for base of tongue carcinomas and by $0.6 \%$ for tonsillar carcinomas every year between 1973 and 2004 in the USA, and in the Netherlands Rietbergen et al. ${ }^{7,8}$ show an increase in the proportion of HPV-positive OPSCC from $5.1 \%$ in 1990 to $29 \%$ in 2010. In contrast to OPSCC we only detected HPV in 1 out of 46 HPSCC. This is in accordance with a recent study of Wendt et al., who detected 4 HPV16positive and $\mathrm{p} 16^{\mathrm{INK} 4 \mathrm{~A}}$ positive tumours out of $109 \mathrm{HPSCC}^{28}$ Several other studies observed higher frequencies of HR-HPV-positive HPSCC, ranging from $20 \%$ to even $82 \%,{ }^{29-31}$ but these studies did not apply the algorithm of $\mathrm{p} 16^{\text {INK } 4 \mathrm{~A}}$ immunohistomchemistry followed by HPV-specific DNA-analyses to identify relevant HPV-related tumours. Remarkably, Ernoux-Neufcoeur et al. did 
immunostain their tumour collection for $\mathrm{p} 16^{\text {INK4A }}$ overexpression, which resulted in only $11 \%$ HPV-positive and $\mathrm{p} 16^{\mathrm{INK} 4 \mathrm{~A}}$ positive cases. ${ }^{31}$

The influence of tumour HPV-status on outcome after CRT has been investigated in several studies and in a variety of treatment combinations, differing amongst others in timing of chemotherapy, use of different drugs and poly/monochemotherapy. ${ }^{32}$ We observed a more favourable overall and disease free survival for patients with an HPV-positive OPSCC treated by concurrent radiotherapy and cisplatin. This is in accordance with other studies using a similar treatment modality or other combinations of chemotherapeutic drugs with radiotherapy. ${ }^{11,32,33}$

We have also analysed EGFR expression in our tumour series in relation to HPV-status and patient survival, because previous studies suggest that HPV-positive tumours show less frequently EGFR overexpression than HPV-negative tumours ${ }^{15,16,34}$ and that EGFR overexpression results in an unfavourable prognosis. ${ }^{15,16}$ In our study, we did not find a correlation between HPV-positivity and no/low EGFR expression, and in comparison with these studies, we even detected a relatively high prevalence of EGFR immunopositivity in the HPV-positive tumours. This might be due to the fact that our series contains a relatively high amount of advanced tumours, which has been reported to be associated with a higher occurrence of EGFR overexpression. ${ }^{15}$ Interestingly, although EGFR overexpression did not correlate with a poor prognosis in our series of OPSCC, it did predict a significant worse survival in the HPV-positive tumour group. This implicates that for accurate prediction of prognosis of OPSCC patients EGFR expression might be an additional factor to take into consideration, besides HPV-status, smoking and $\mathrm{N}$-stage, as suggested by Ang et al. ${ }^{11}$ Recently new prediction models have been proposed for HNSCC by Egelmeer et al. ${ }^{35}$ and Rietbergen et al. ${ }^{8}$ and it will be interesting to determine if EGFR expression can improve the value of these models when applied to OPSCC.

Despite the fact that HPV-positive tumours have a good overall and disease free survival when treated with CRT, this is a toxic treatment with severe adverse events. As a consequence, trials, such as the RTOG1016 trial in the USA and the De-ESCALaTE HPV trial in Europe, have been initiated to examine if de-escalation of therapy can reduce toxicity in this subgroup while maintaining favourable prognosis. ${ }^{36,37}$ For example, use of radiotherapy alone has been proven to show good survival rates when compared to CRT for the HPV-positive low-risk group. ${ }^{9,38}$ 
In case of HPV-positive tumours with EGFR overexpression (having a worse prognosis) we would not recommend to use de-escalation of therapy. In these cases it would be interesting to analyse if a combination of cetuximab with radiotherapy might be a better option than chemoradiation, which remains to be studied.

Because EGFR immunohistochemistry may vary in staining protocol, signal interpretation and used primary antibody clone when applied in different molecular diagnostic laboratories, ${ }^{39}$ it is important to develop standardized protocols and scoring criteria (as developed for $\left.\mathrm{p} 16^{\mathrm{INK} 4 \mathrm{~A}}\right)^{40,41}$ to reliably use this marker in future risk models or as potential indicator for targeted therapy in HPV-positive OPSCC.

In conclusion, our data show that $\mathrm{p} 16^{\mathrm{INK} 4 \mathrm{~A}}$ is an excellent surrogate marker for HR-HPV in the here studied OPSCCs and HPSCCs, all treated with chemoradiation therapy. HPV-presence in advanced OPSCC predicts a decreased risk of locoregional recurrences, distant metastasis and a favourable overall survival. Interestingly, EGFR overexpression marks a distinct subgroup of HPV-positive tumours with a significantly worse survival. We suggest EGFR expression to be taken into consideration as additional marker in future riskmodels for OPSCC and to be explored as potential biomarker for anti-EGFR targeted therapy in HPV-positive OPSCC. 


\section{Supplemental table and figure}

Table S6.1 Clinical and molecular characteristics of HPSCC.

\begin{tabular}{|c|c|}
\hline Characteristic & $\mathrm{N}(\%)$ \\
\hline \multicolumn{2}{|l|}{ Gender } \\
\hline Male & $35(76 \%)$ \\
\hline Female & $11(24 \%)$ \\
\hline \multicolumn{2}{|l|}{ Age at diagnosis } \\
\hline$>60$ & $20(43 \%)$ \\
\hline$<60$ & $26(57 \%)$ \\
\hline \multicolumn{2}{|l|}{ T-stage } \\
\hline T2 & $8(18 \%)$ \\
\hline T3 & $18(39 \%)$ \\
\hline T4 & $20(43 \%)$ \\
\hline \multicolumn{2}{|l|}{$\mathrm{N}$-stage } \\
\hline No & $14(30 \%)$ \\
\hline N1 & $6(13 \%)$ \\
\hline $\mathrm{N} 2$ & $16(35 \%)$ \\
\hline N3 & $10(22 \%)$ \\
\hline \multicolumn{2}{|l|}{ M-stage } \\
\hline M0 & $39(85 \%)$ \\
\hline M1 & $7(15 \%)$ \\
\hline \multicolumn{2}{|c|}{ Locoregional recurrence } \\
\hline Yes & $6(13 \%)$ \\
\hline No & $40(87 \%)$ \\
\hline \multicolumn{2}{|l|}{ Disease recurrence } \\
\hline Yes & $13(28 \%)$ \\
\hline No & $33(72 \%)$ \\
\hline \multicolumn{2}{|l|}{$\mathrm{HPV}+/ \mathrm{p} 16^{\mathrm{INK} 4 \mathrm{~A}}+$} \\
\hline Positive & $1(2 \%)$ \\
\hline Negative & $45(98 \%)$ \\
\hline \multicolumn{2}{|l|}{ EGFR } \\
\hline Positive & $37(80 \%)$ \\
\hline Negative & $9(20 \%)$ \\
\hline
\end{tabular}

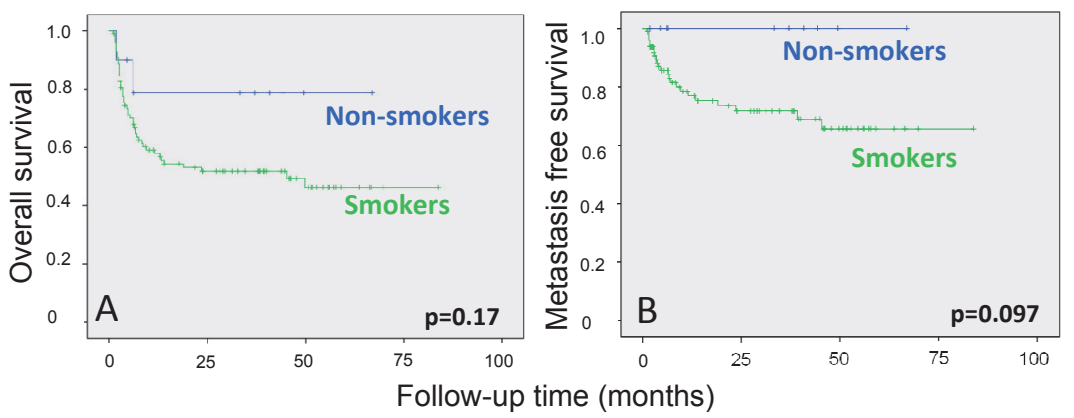

Figure S6.1 Kaplan Meier curves according to smoking status for (A) overall survival and (B) distant metastases free survival in 108 OPSCC. 


\section{References}

1. Ferlay J, Parkin DM, Steliarova-Foucher E. Estimates of cancer incidence and mortality in Europe in 2008. Eur J Cancer 2010;46:765-81.

2. León X, Gich I, Orús C, Del Prado Venegas M, Ramón Gras J, Quer M. Comparison of the Radiation Therapy Oncology Group recursive partitioning classification and Union Internationale Contre le Cancer TNM classification for patients with head and neck carcinoma. Head Neck 2005;27:248-57.

3. Rasch CR, Hauptmann M, Schornagel J, Wijers O, Buter J, Gregor T, Wiggenraad R, de Boer JP, Ackerstaff AH, Kroger R, Hoebers FJ, Balm AJ, Hilgers FJ. Intraarterial versus intravenous chemoradiation for advanced head and neck cancer: Results of a randomized phase 3 trial. Cancer 2010;116:2159-65.

4. El-Mofty SK, Lu DW. Prevalence of high-risk human papillomavirus DNA in nonkeratinizing (cylindrical cell) carcinoma of the sinonasal tract: a distinct clinicopathologic and molecular disease entity. Am J Surg Pathol 2005;29:1367-72.

5. Gillison ML, Koch WM, Capone RB, Spafford M, Westra WH, Wu L, Zahurak ML, Daniel RW, Viglione M, Symer DE, Shah KV, Sidransky D. Evidence for a causal association between human papillomavirus and a subset of head and neck cancers. J Natl Cancer Inst, 2000;92:709-20.

6. Klussmann JP, Weissenborn SJ, Wieland U, Dries V, Kolligs J, Jungehuelsing M, Eckel HE, Dienes HP, Pfister HJ, Fuchs PG. Prevalence, distribution, and viral load of human papillomavirus 16 DNA in tonsillar carcinomas. Cancer 2001;92:2875-84.

7. Marur S, D'Souza G, Westra WH, Forastiere AA. HPV-associated head and neck cancer: a virus-related cancer epidemic. Lancet Oncol 2010;11:781-9.

8. Rietbergen MM, Leemans CR, Bloemena E, Heideman DA, Braakhuis BJ, Hesselink AT, Witte BI, Baatenburg de Jong RJ, Meijer CJ, Snijders PJ, Brakenhoff $\mathrm{RH}$. Increasing prevalence rates of HPV attributable oropharyngeal squamous cell carcinomas in the Netherlands as assessed by a validated test algorithm. Int $\mathrm{J}$ Cancer 2013;132:1565-71.

9. O'Sullivan B, Huang SH, Siu LL, Waldron J, Zhao H, Perez-Ordonez B, Weinreb I, Kim J, Ringash J, Bayley A, Dawson LA, Hope A, Cho J, Irish J, Gilbert R, Gullane $P$, Hui A, Liu FF, Chen E, Xu W. Deintensification candidate subgroups in human papillomavirus-related oropharyngeal cancer according to minimal risk of distant metastasis. J Clin Oncol 2013;31:543-50.

10. Hafkamp HC, Manni JJ, Haesevoets A, Voogd AC, Schepers M, Bot FJ, Hopman $\mathrm{AH}$, Ramaekers FC, Speel EJ. Marked differences in survival rate between smokers and nonsmokers with HPV 16-associated tonsillar carcinomas. Int J Cancer 2008;122:2656-64.

11. Ang KK, Harris J, Wheeler R, Weber R, Rosenthal DI, Nguyen-Tân PF, Westra $\mathrm{WH}$, Chung $\mathrm{CH}$, Jordan RC, Lu C, Kim H, Axelrod R, Silverman CC, Redmond KP, Gillison ML. Human papillomavirus and survival of patients with oropharyngeal cancer. N Engl J Med 2010;363:24-35.

12. Olthof NC, Straetmans JM, Snoeck R, Ramaekers FC, Kremer B, Speel EJ. Nextgeneration treatment strategies for human papillomavirus-related head and neck squamous cell carcinoma: where do we go? Rev Med Virol 2012;22:88-105.

13. Hafkamp HC, Speel EJ, Haesevoets A, Bot FJ, Dinjens WN, Ramaekers FC, Hopman AH, Manni JJ. A subset of head and neck squamous cell carcinomas exhibits integration of HPV 16/18 DNA and overexpression of p16INK4A and p53 in the absence of mutations in p53 exons 5-8. Int J Cancer 2003;107:394-400. 
14. Wiest T, Schwarz E, Enders C, Flechtenmacher C, Bosch FX. Involvement of intact HPV16 E6/E7 gene expression in head and neck cancers with unaltered p53 status and perturbed pRb cell cycle control. Oncogene 2002;21:1510-7.

15. Reimers N, Kasper HU, Weissenborn SJ, Stützer H, Preuss SF, Hoffmann TK, Speel EJ, Dienes HP, Pfister HJ, Guntinas-Lichius O, Klussmann JP. Combined analysis of HPV-DNA, p16 and EGFR expression to predict prognosis in oropharyngeal cancer. Int J Cancer 2007;120:1731-8.

16. Kumar B, Cordell KG, Lee JS, Worden FP, Prince ME, Tran HH, Wolf GT, Urba SG, Chepeha DB, Teknos TN, Eisbruch A, Tsien CI, Taylor JM, D'Silva NJ, Yang K, Kurnit DM, Bauer JA, Bradford CR, Carey TE. EGFR, p16, HPV Titer, Bcl-xL and p53, sex, and smoking as indicators of response to therapy and survival in oropharyngeal cancer. J Clin Oncol 2008;26:3128-37.

17. Herrero R, Castellsagué X, Pawlita M, Lissowska J, Kee F, Balaram P, Rajkumar $T$, Sridhar $H$, Rose $B$, Pintos J, Fernández L, Idris $A$, Sánchez MJ, Nieto $A$, Talamini R, Tavani A, Bosch FX, Reidel U, Snijders PJ, Meijer CJ, Viscidi R, Muñoz N, Franceschi S; IARC Multicenter Oral Cancer Study Group. Human papillomavirus and oral cancer: the International Agency for Research on Cancer multicenter study. J Natl Cancer Inst 2003;95:1772-83.

18. Lassen P, Eriksen JG, Hamilton-Dutoit S, Tramm T, Alsner J, Overgaard J; Danish Head and Neck Cancer Group (DAHANCA). HPV-associated p16-expression and response to hypoxic modification of radiotherapy in head and neck cancer. Radiother Oncol 2010;94:30-5.

19. Kies MS, Holsinger FC, Lee JJ, William WN Jr, Glisson BS, Lin HY, Lewin JS, Ginsberg LE, Gillaspy KA, Massarelli E, Byers L, Lippman SM, Hong WK, ElNaggar AK, Garden AS, Papadimitrakopoulou V. Induction chemotherapy and cetuximab for locally advanced squamous cell carcinoma of the head and neck: results from a phase II prospective trial. J Clin Oncol 2010;28:8-14.

20. Pramana J, Van den Brekel MW, van Velthuysen ML, Wessels LF, Nuyten DS, Hofland I, Atsma D, Pimentel N, Hoebers FJ, Rasch CR, Begg AC. Gene expression profiling to predict outcome after chemoradiation in head and neck cancer. Int J Radiat Oncol Biol Phys 2007;69:1544-52.

21. Chen B, van den Brekel MW, Buschers W, Balm AJ, van Velthuysen ML. Validation of tissue array technology in head and neck squamous cell carcinoma. Head Neck 2003;25:922-30.

22. Hafkamp HC, Mooren JJ, Claessen SM, Klingenberg B, Voogd AC, Bot FJ, Klussmann JP, Hopman AH, Manni JJ, Kremer B, Ramaekers FC, Speel EJ. P21 Cip1/WAF1 expression is strongly associated with HPV-positive tonsillar carcinoma and a favorable prognosis. Mod Pathol 2009;22:686-98.

23. Speel EJ, Ramaekers FC, Hopman AH. Sensitive multicolor fluorescence in situ hybridization using catalyzed reporter deposition (CARD) amplification. J Histochem Cytochem 1997;45:1439-46.

24. Mooren JJ, Kremer B, Claessen SM, Voogd AC, Bot FJ, Peter Klussmann J, Huebbers CU, Hopman AH, Ramaekers FC, Speel EJ. Chromosome stability in tonsillar squamous cell carcinoma is associated with HPV16 integration and indicates a favorable prognosis. Int J Cancer 2013;132:1781-9.

25. Baay MF, Koudstaal J, Hollema H, Duk JM, Burger MP, Quint WG, Stolz E, Herbrink P. Detection of HPV-16 DNA by PCR in histologically cancer free lymph nodes from patients with cervical cancer. J Clin Pathol 1997;50:960-1. 
26. van den Brule AJ, Pol R, Fransen-Daalmeijer N, Schouls LM, Meijer CJ, Snijders PJ. GP5+/6+ PCR followed by reverse line blot analysis enables rapid and highthroughput identification of human papillomavirus genotypes. J Clin Microbiol 2002;40:779-87.

27. Ragin CC, Taioli E. Survival of squamous cell carcinoma of the head and neck in relation to human papillomavirus infection: review and meta-analysis. Int $\mathrm{J}$ Cancer 2007;121:1813-20.

28. Wendt M, Romanitan M, Näsman A, Dalianis T, Hammarstedt L, Marklund L, Ramqvist T, Munck-Wikland E. Presence of human papillomaviruses and p16 expression in hypopharyngeal cancer. Head Neck 2014;36:107-12.

29. Hoffmann M, Görögh T, Gottschlich S, Lohrey C, Rittgen W, Ambrosch P, Schwarz E, Kahn T. Human papillomaviruses in head and neck cancer: 8 year-survivalanalysis of 73 patients. Cancer Lett 2005;218:199-206.

30. Sethi S, Ali-Fehmi R, Franceschi S, Struijk L, van Doorn LJ, Quint W, Albashiti B, Ibrahim M, Kato I. Characteristics and survival of head and neck cancer by HPV status: a cancer registry-based study. Int J Cancer 2012;131:1179-86.

31. Ernoux-Neufcoeur P, Arafa M, Decaestecker C, Duray A, Remmelink M, Leroy X, Herfs M, Somja J, Depuydt CE, Delvenne P, Saussez S. Combined analysis of HPV DNA, p16, p21 and p53 to predict prognosis in patients with stage IV hypopharyngeal carcinoma. J Cancer Res Clin Oncol 2011;137:173-81.

32. Lassen P1, Eriksen JG, Hamilton-Dutoit S, Tramm T, Alsner J, Overgaard J. Effect of HPV-associated p16INK4A expression on response to radiotherapy and survival in squamous cell carcinoma of the head and neck. J Clin Oncol 2009;27:1992-8.

33. Rischin D, Young RJ, Fisher R, Fox SB, Le QT, Peters LJ, Solomon B, Choi J, O'Sullivan B, Kenny LM, McArthur GA. Prognostic significance of p16INK4A and human papillomavirus in patients with oropharyngeal cancer treated on TROG 02.02 phase III trial. J Clin Oncol 2010;28:4142-8.

34. Kim SH, Koo BS, Kang S, Park K, Kim H, Lee KR, Lee MJ, Kim JM, Choi EC, Cho $\mathrm{NH}$. HPV integration begins in the tonsillar crypt and leads to the alteration of $\mathrm{p} 16$, EGFR and c-myc during tumor formation. Int J Cancer 2007;120:1418-25.

35. Egelmeer AG, Velazquez ER, de Jong JM, Oberije C, Geussens Y, Nuyts S, Kremer B, Rietveld D, Leemans CR, de Jong MC, Rasch C, Hoebers F, Homer J, Slevin N, West C, Lambin P. Development and validation of a nomogram for prediction of survival and local control in laryngeal carcinoma patients treated with radiotherapy alone: a cohort study based on 994 patients. Radiother Oncol 2011;100:108-15.

36. Zandberg DP, Bhargava R, Badin S, Cullen KJ. The role of human papillomavirus in nongenital cancers. CA Cancer J Clin 2013;63:57-81.

37. Brakenhoff RH. Potentially novel options for treatment of HPV-attributable head and neck cancer. Cell Cycle 2013;12:1020-1.

38. Sinha P, Lewis JS Jr, Piccirillo JF, Kallogjeri D, Haughey BH. Extracapsular spread and adjuvant therapy in human papillomavirus-related, p16-positive oropharyngeal carcinoma. Cancer 2012;118:3519-30.

39. Thunnissen E, Bovée JV, Bruinsma H, van den Brule AJ, Dinjens W, Heideman DA, Meulemans E, Nederlof P, van Noesel C, Prinsen CF, Scheidel K, van de Ven PM, de Weger R, Schuuring E, Ligtenberg M. EGFR and KRAS quality assurance schemes in pathology: generating normative data for molecular predictive marker analysis in targeted therapy. J Clin Pathol 2011;64:884-92. 
40. Rietbergen MM1, Snijders PJ, Beekzada D, Braakhuis BJ, Brink A, Heideman DA, Hesselink AT, Witte BI, Bloemena E, Baatenburg-De Jong RJ, Leemans CR, Brakenhoff $\mathrm{RH}$. Molecular characterization of p16-immunopositive but HPV DNAnegative oropharyngeal carcinomas. Int J Cancer, 2014;134:2366-72.

41. Mooren JJ, Kremer B, Claessen SM, Voogd AC, Bot FJ, Peter Klussmann J, Huebbers CU, Hopman AH, Ramaekers FC, Speel EJ. Chromosome stability in tonsillar squamous cell carcinoma is associated with HPV16 integration and indicates a favorable prognosis. Int J Cancer 2013;132:1781-9. 


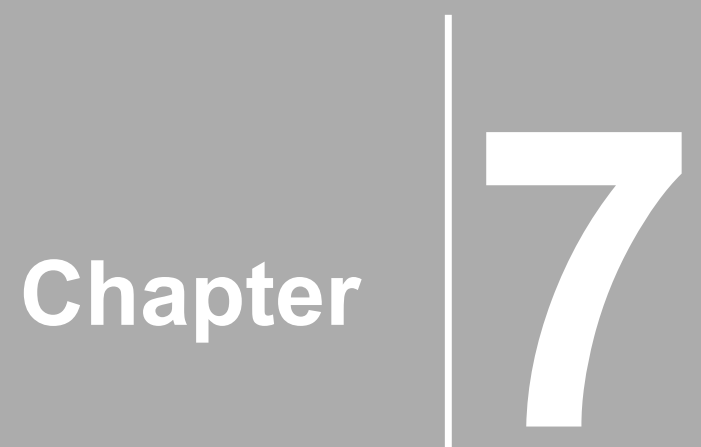

GENERAL DISCUSSION AND CONCLUSION 


\section{General discussion and conclusion}

Currently HPV is one of the most common sexually transmitted infections worldwide.

About half of new infections are detected in young people aged between 15 and 24 , but nearly all sexually active men and women become infected with HPV at some point in their life. Most of them, however, will remain asymptomatic, because the virus will be cleared by the immune system in about $90 \%$ of cases within 1 or 2 years. This is true of both HR- and LR-HPV types. The remaining $10 \%$ will retain a persistent infection with an increased risk of cancer development in the case of an HR-HPV infection. According to Zandberg et al. ${ }^{1}$ approximately half of these individuals will develop a carcinoma after on average 30 years of persistent infection.

In the past decade, the increasing incidence of OPSCC has been widely attributed to HPV-infection. In the last few years several studies have reported clinical and molecular differences between HPV-induced OPSCC as compared to smoking- and/ or alcohol-induced cases. The reported overall incidence of HPV in OPSCC ranges from less than $20 \%$ to more than $90 \%$ in different studies. Amongst others, geographical features, differences in tobacco and alcohol consumption, differences in sexual behaviour (more oral sex and/or sexual partners), sample preparation and also the type of HPV-detection methods, have been put forward as explanation for this variation., ${ }^{2,3}$

Many different HPV-detection methods are available, all with their pros and cons when taking aspects like sensitivity, specificity, practicability and costs into consideration. Until now, there is still no current standard for testing or interpretation of HPV-presence. It has been shown that not all tumours tested positive for HPV-DNA can be regarded as etiologically HPV-related, i.e. being caused by a clinically relevant infection. The latter can be recognized by detectable expression of the viral oncogenes $E 6$ and $E 7,,^{4-6}$ as has been described in detail in the Introduction of this thesis. For daily practice, overexpression of $\mathrm{p} 16^{\mathrm{INK} 4 \mathrm{~A}}$ has been put forward as a specific surrogate biomarker for the presence of HR-HPV, in particular in (pre)malignancies of the uterine cervix, but also for those in the head and neck region. ${ }^{7-10}$ In the latter the discriminating power of this biomarker is even enhanced, because in smoking- and/or alcohol-induced HPV-negative OPSCC p16 ${ }^{\text {INK4A }}$ is often downregulated as a result of chromosome 9p21 loss. Nevertheless, the reliability of $\mathrm{p} 16^{\mathrm{INK} 4 \mathrm{~A}}$ as a surrogate marker for HPV-presence is still subject to debate, for example because standardization and evaluation criteria for staining protocols are still lacking. ${ }^{11,12}$ 


\section{Reliability of $\mathrm{p} 16^{\mathrm{INK} 4 \mathrm{~A}}$ immunohistochemistry as surrogate marker for HPV}

The first study in this thesis (chapter 2), therefore, examined the predictive value of $\mathrm{p} 16^{\mathrm{INK} 4 \mathrm{~A}}$ in the distinction between HPV-positive and HPV-negative head and neck lesions.

In this study $\mathrm{p} 16^{\mathrm{INK} 4 \mathrm{~A}}$ immunohistochemistry was combined with HPV-specific FISH and PCR to detect the presence of HPV in benign and (pre)-malignant head and neck cases. Taken together, the $\mathrm{p} 16^{\mathrm{INK} 4 \mathrm{~A}}$ immunohistochemical staining results showed a sensitivity of $98 \%$ and a specificity of $95 \%$ for HPVpresence in OPSCC, when using a cut-off point of $70 \%$ of tumour cells showing diffuse cytoplasmic and/or nuclear immunopositivity. Recent literature is in agreement with this finding. ${ }^{13-16}$ In initial studies, including those from our own laboratory, $7,17,18$ lower cut-off values of $\geq 25 \%$ were used, in general derived from cut-off values for the expression of other proteins involved in cell cycle regulation such as $\mathrm{pRb}$ and $\mathrm{p53}$. In theory this cut-off value may lead to higher false positivity than with a cut-off value of $70 \%$, although in practice this is seldomly observed, because almost always HPV-positive tumours are p16 INK4A immunopositive in all tumour cells.

In the case of benign and premalignant head and neck lesions, however, the relation between $\mathrm{p} 16^{\mathrm{INK} 4 \mathrm{~A}}$ and HPV-positivity is less clear. Chapter 2 shows that $\mathrm{p} 16^{\mathrm{INK} 4 \mathrm{~A}}$ is a reliable surrogate marker for HR-HPV in tonsillar dysplasias, when using $70 \%$ immunopositivity as cut-off and that this positivity is observed en bloc, defined as cellular staining observed in the basal cell layer with extension upwards. However, in tonsillar and laryngeal papillomas, as well as laryngeal dysplasias $\mathrm{p} 16^{\mathrm{INK} 4 \mathrm{~A}}$ immunostaining patterns are highly variable and not en bloc, and moreover irrespective of the HPV-status. Thus, caution is recommended when using $\mathrm{p} 16^{\mathrm{INK} 4 \mathrm{~A}}$ expression as surrogate marker for HPV-infection in these lesions. In studies described in this thesis a few HPV-negative OPSCC and tonsillar dysplasias were $\mathrm{p} 16^{\mathrm{INK} 4 \mathrm{~A}}$ positive. This $\mathrm{p} 16^{\mathrm{INK} 4 \mathrm{~A}}$ false-positivity may result from deregulation of the cell cycle by means of mutations in the pRb pathway, or by other mechanisms, such as infection with other viruses, ${ }^{19-21}$ physiological stress, oncogene-driven senescence, or replicative senescence due to DNA-damage or oxidative stress. ${ }^{22-25}$

On the other hand, LR-HPV containing benign and premalignant head and neck lesions can be $\mathrm{p} 16^{\text {INK4A }}$ negative. This may be explained by the fact that the interaction of the oncogenes E6 and E7 with p53 and pRb is different between LR- and HR-HPV. ${ }^{26}$

The study described in Chapter 3 shows that in addition to $\mathrm{p} 16^{\text {INK4A }}$ overexpression also certain expression levels of other cell cycle proteins were observed to be significantly associated with HPV-positivity, i.e. downregulation of cyclin $\mathrm{D} 1$ and $\mathrm{pRb}$ and overexpression of $\mathrm{p} 14^{\mathrm{ARF}}$ and $\mathrm{p} 21^{\mathrm{Cip} 1 \text { /NAF } 1}$. All these 
proteins, however, did not approximate the sensitivity of the $\mathrm{p} 16^{\mathrm{INK} 4 \mathrm{~A}}$ staining. Nevertheless, other studies have shown $\mathrm{p} 16^{\text {INK4A }}$ positive/ HPV-negative tumours in up to $15-20 \%$ of OPSCC. ${ }^{27-29}$ Holzinger et al. therefore proposed to use a combination of two cell cycle markers to predict the presence of HR-HPV. ${ }^{28}$

To summarize, $\mathrm{p} 16^{\mathrm{INK} 4 \mathrm{~A}}$ immunostaining is a relatively low-cost, fast and easy to perform technique, making it a practical and reliable procedure to predict the presence of HR-HPV with a high sensitivity and specificity. A drawback of this method is that it cannot reliably be used for detection of LR-HPV. To overcome p $16^{\text {INK4A }}$ false-positivity, the presence of HPV always needs to be confirmed by applying HPV-specific FISH and/or or RT-PCR analysis of E6/E7 transcripts after HPV-typing. ${ }^{17,30,31}$ In case of $\mathrm{p} 16^{\mathrm{INK} 4 \mathrm{~A}}$ negativity in OPSCC no further analyses are needed, thereby omitting the need for more time-consuming and costly diagnostic procedures.

\section{Clinical and molecular parameters distinguishing HPV- positive from HPV-negative OPSCC}

A second aim of the studies described in this thesis was to gain more insight into the molecular changes occurring in head and neck carcinogenesis as a result of HPV-infection and the clinical characteristics that separate HPV-positive from HPV-negative tumours. It was envisaged that new prognostic and/ or therapeutic biomarkers could arise from such investigations. Based on molecular and clinical parameters analyzed in chapters 2 to 6 as well as on findings described in the recent literature, there is now substantial evidence that HPV-positive OPSCC are different from HPV-negative OPSCC and can be considered as a separate biological entity. A summary of clinical and molecular parameters in OPSCC in relation to HPV-status is presented in Table 7.1.

Clinically, HPV-positive OPSCC have a favourable prognosis, despite the fact that these tumours are often poorly differentiated and metastasized to lymph nodes at presentation. ${ }^{32-35}$ Furthermore, HPV-positive OPSCC are often smaller at first diagnosis and found in patients, that are less likely to have a history of smoking and alcohol consumption and have a higher number of sexual partners, particularly oral sex partners. ${ }^{36-39}$ A significant association between HPV-positivity on the one side and younger age and higher occurrence in male patients on the other side is less clear from the literature and could not be observed in the studies performed in the present thesis, except for the higher male-female ratio found in the study population in chapter 6. 
The study described in chapter 3 has shown different expression profiles for proteins particularly involved in the cell cycle and cell survival pathways when comparing HPV-positive and HPV-negative tumours. This could be regarded as a foreseeable observation when taking into account the direct interaction of the viral oncoproteins E6 and E7 with the tumour suppressor proteins p53 and $\mathrm{pRb}$, respectively. However, the present study is the first in literature correlating the expression levels of all these cell cycle proteins with each other, with the presence of HPV and with patient survival. The most striking observation from a multivariate analysis of these parameters was that p21 Cip1/WAF1 overexpression appeared to be one of the most significant independent indicators of favourable prognosis in TSCC patients. The fact that $\mathrm{p} 21^{\text {Cip } 1 \text { /WAF } 1}$ overexpression showed an even stronger correlation with favourable prognosis than the presence of HPV, suggests that this biomarker should be seriously considered as an additional prognosticator in risk-models, such as the one proposed by Ang et al, ${ }^{32}$ which will be discussed in more detail in the next paragraph.

Furthermore, HPV-positive OPSCC contain less genetic alterations and less chromosomal instability than the HPV-negative cases. ${ }^{40,41}$ This aspect has been described in more detail in chapters 4 and 5 , and may be explained by the fact that the number of required genetic alterations for a malignant phenotype is lower in HPV-driven tumourigenesis, again due to the fact that E6 and E7 occupy strategic positions in the cell regulatory pathways involving p53 and $\mathrm{pRb}$. Two large-scale whole-exome sequencing studies of head and neck cancers also found significantly more gene mutations in HPV-negative than in HPV-positive tumours, ${ }^{42,43}$ with the exception of PIK3CA, an oncogene that is more often mutated in HPV-positive than in HPV-negative OPSCC (approximately $25 \%$ versus $7 \%$, respectively). ${ }^{42-44}$ Since the PIK3CA pathway plays key regulatory roles in cell survival, proliferation and differentiation it is of importance that the mechanism by which the PIK3CA pathway is influenced by HPV will be unraveled in future studies. ${ }^{45}$

It is well established that high-grade tumours generally show increased levels of genetic instability. This is in accordance with our observation in chapter 5 , in which we found more often aneusomy for chromosomes 1 and 7 in higher T-stages. As the EGFR gene is located on chromosome 7, this may also explain the higher EGFR immunohistochemical staining levels which we detected in advanced tumours in chapter 6, despite the fact that EGFR overexpression is usually absent in HPV-positive tumours. ${ }^{46}$

A number of studies screened for genomic alterations (genomic methylation, microRNA and mRNA expression) and identified specific signatures for HPV-positive tumours and patient survival. ${ }^{47-57}$ Three microarray studies revealed several upregulated gene expression profiles in HPV-positive tumours compared to HPV-negative tumours, although with little overlap of the reported 
profiles between studies. ${ }^{55-57}$ Amongst these genes were cell cycle regulators, such as $\mathrm{p} 16^{\mathrm{INK} 4 \mathrm{~A}}$ and $\mathrm{p} 18^{\mathrm{INK} 4 \mathrm{C}}, 53$ and also distinct microRNA profiles that clearly distinguish HPV-positive from HPV-negative tumours have shown to target mRNAs encoding tumour suppressing proteins involved in G1/S checkpoint, ${ }^{50}$ whereas others may be involved in amongst others immune regulation. ${ }^{52}$

Interestingly, the majority of HPV-positive tumours express high levels of tumour infiltrating lymfocytes in comparison with HPV-negative tumours (49\% versus $16 \%$, respectively, ${ }^{58}$ as well as high expression of the ligand (PD-L1) for the immune checkpoint receptor programmed cell death-1 (PD-1) $(70 \%$ versus $29 \%$, respectively). ${ }^{59}$ Expanded phase I clinical studies have observed clinical responses in blocking the PD-1 immune checkpoint in renal cell carcinoma, melanoma and non-small cell lung cancer, ${ }^{59}$ making this also a potential targeted therapy for HPV-positive OPSCC.

Table 7.1 Clinical and molecular differences between HPV-positive and HPV-negative OPSCC*

\begin{tabular}{lll}
\hline & HPV-positive OPSCC & HPV-negative OPSCC \\
\hline Clinical characteristics & & \\
Preferred location & Oropharynx & All head and neck sites \\
Differentiation degree & Poorly & Moderately to well \\
Levels of tumour infiltrating lymphocytes & High & Low \\
T-stage & T1-2 & Variable (T3-4) \\
N-stage & N+ & NO-N3 \\
Disease stage (TNM) & More advanced & Less advanced \\
Etiological factors & Sexual behaviour & Smoking, alcohol \\
Average age & $<60$ years & $>60$ years \\
5-years survival & $70-90 \%$ & $30-60 \%$ \\
Second primary tumour within 5 years & $0-10 \%$ & $10-15 \%$ \\
Local recurrences within 5 years & $10-20 \%$ & $25-55 \%$ \\
Molecular characteristics & & \\
E6/E7 expression & + & - \\
p16 & + & - \\
p53 downregulation & + & - \\
pRb downregulation & + & - \\
p21 & + & - \\
p14 $14^{\text {ARF }}$ overexprexpression & + & - \\
cyclin D1 overexpression & - & + \\
EGFR overexpression & $-($ advanced tumours: & + \\
11q13 gain; 3p, 9p, 18q loss & - & + \\
Genetic alterations & Less & Many \\
Number of mutations & Less & Many \\
PIK3CA mutations & $25 \%$ & $7 \%$ \\
\hline
\end{tabular}

* Summarized from ${ }^{5,8,17,27,30-32,42-45,58,60-65}$ 


\section{HPV-status and other prognosticators in OPSCC}

Another aim of this thesis was to analyze the influence of HPV and the identified molecular changes on patient survival. In the clinical diagnostic workup of OPSCC HPV-status is more and more often included. However, until now therapeutic regimes for HPV-positive tumours do not differ from those for HPV-negative OPSCC.

HPV-positivity is a strong indicator of favourable prognosis in OPSCC patients, independent of treatment modalities. This may be explained by the different biology of these tumours: a) HPV-positive tumour cells are more radiosensitive, ${ }^{66}$ which seems to be associated with a sustained G2-arrest and impaired DNA repair capacity. In these processes p53 does not seem to play a role. ${ }^{67}$ However, the role of wild-type p53 appears to be more evident when combining radiotherapy with the use of nucleotide analogs, such as the antiviral agent Cidofovir. ${ }^{68}$ In these cases p53 seems to be upregulated inducing apoptosis and G1 cell cycle arrest. This effect has also been observed when E6 and E7 gene expression is targeted by short siRNAs. ${ }^{69}$ b) HPV-positive tumours are characterized by less mutations and less genetic alterations, as well as lower EGFR levels; ${ }^{42,43,46,61,62}$ c) HPV-positive tumours are found in patients with less exposure to tobacco and alcohol, thereby reducing field cancerization and the chance of developing secondary primary tumours and distant metastases; ${ }^{17,70,71}$ d) HPV-positive tumours often present as a lymph node metastasis in the neck, that is derived from a usual small primary OPSCC, which makes radical treatment more feasible, ${ }^{65,72}$ e) Patients with an HPV-positive tumour tend to be younger with better performance and less comorbidities; ${ }^{21,73}$ f) HPV-positive OPSCC have more often high levels of tumour infiltrating lymphocytes, indicating the presence of an adaptive host anti-tumour immune response. ${ }^{58}$

Because head and neck cancer therapies have a high incidence of treatment morbidity, which strongly impairs quality of life, there is a great deal of interest in equally (or even more) effective therapies with fewer adverse effects. One should notice, however, that the HPV-positive tumour group is not homogenous, with not all HPV-positive tumours having such a favourable prognosis. Smoking, for example, is an indicator of unfavourable prognosis within the HPV-positive patient group. ${ }^{17,32}$ Based on clinical and molecular characteristics, several studies have attempted to better predict survival rates of patients with an HPV-positive OPSCC. Ang et al. enrolled 743 patients with stage III and IV HNSCC, randomly assigned to receive high-dose cisplatin concurrently with either accelerated-fractionation radiotherapy or standardfractionation radiotherapy. Their study did not reveal survival differences between these two therapeutic approaches. ${ }^{32}$ However, HPV-status appeared to be the major determinant of overall survival, followed by the number of pack- 
years of smoking ( $\leq 10 \mathrm{vs.}>10$ ) and then nodal stage (N0 to N2a vs. N2b to N3) for HPV-positive tumours, or tumour stage (T2 or T3 vs. T4) for HPV-negative tumours. Based on these parameters a 3-category classification was made with respect to the risk of death, resulting in the algorithm as indicated in Figure $7.1^{32}$

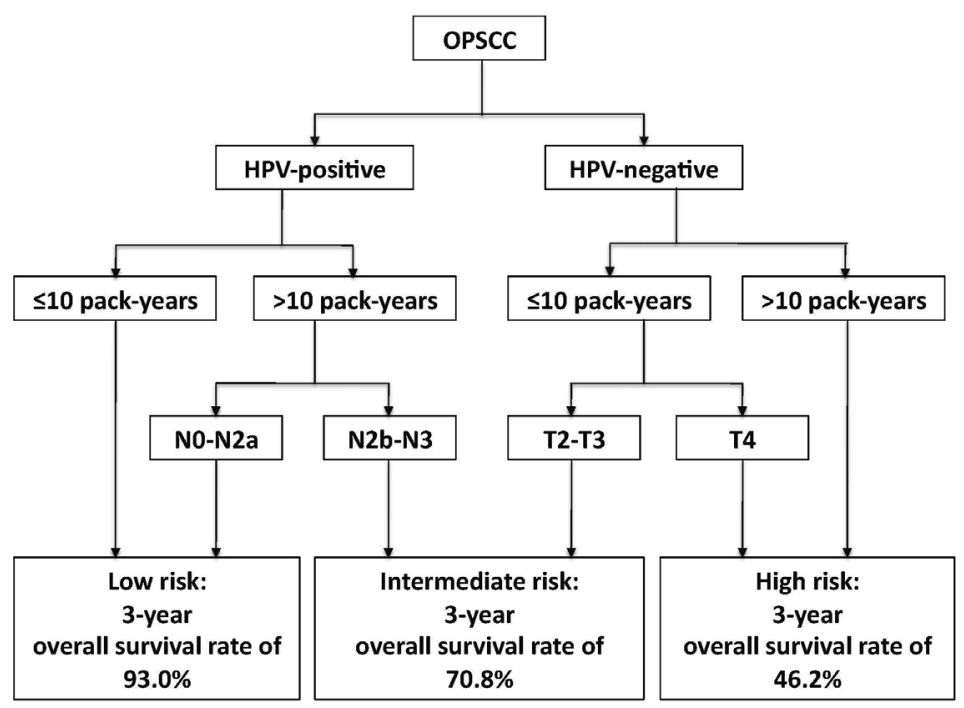

Figure 7.1 Classification of OPSCC patients into risk-of-death categories, based on the indicated prognostic factors.

A recent Dutch study has confirmed this prognostic model, with the remark that comorbidity appeared to be a stronger prognostic factor than smoking, probably because of the high frequency of patients that smoked more than 10 packyears in this study (87.1\%), making this model more suitable for a patient population with a high percentage of heavy smokers, according to the authors. ${ }^{21}$ Clinical parameters and HPV-status have recently also been used in another Dutch study to develop a prognostic nomogram for OPSCC patients (unpublished results). These studies indicate that other prognostic parameters may be taken into consideration to further subdivide HPV-positive OPSCC.

In the underlying thesis also other potential prognostic biomarkers have been explored, and some of these indeed appeared to have a significant influence on patient survival, particularly in the HPV-positive group. Within the study population in chapter 4 a strong correlation between a poor disease-free survival and $9 p$ loss was detected in HPV-positive tumours, despite the low frequency of tumours harbouring this deletion. This finding may be explained by the fact that in these tumours, HPV is a passenger and not the carcinogenic 
initiator. However, because these tumours were $\mathrm{p} 16^{\mathrm{INK} 4 \mathrm{~A}}$ and HPV-positive, this hypothesis is less plausible. A more likely explanation is the loss of, amongst others, $9 p$ in these particularly advanced tumours as a result of aneuploidy with preserved activity of the underrepresented CDKN2A gene (localized at 9p21). As has been shown in chapter 5 , aneuploidy is indeed associated with an unfavourable prognosis in HPV-positive tumours. Finally, the HVP-positive patient population in chapter 6 harbouring EGFR overexpression showed a significantly worse survival compared to HPV-positive tumours showing normal EGFR immunostaining patterns. These findings highlight that not all HPV-positive OPSCC have a similar behaviour and emphasise the need for potential inclusion of the here described factors in addition to HPV-status in future risk models of OPSCC.

\section{Future perspectives: therapeutic and prophylactic alternatives for HPV-positive OPSCC}

Despite the fact that HPV-positive tumours are now considered a separate biological entity, with unique characteristics, the choice of the treatment regimen for OPSCC is currently independent of HPV-status and mainly dependent on the stage of the disease, and patient and clinician preference. Surgery or radiotherapy is usually recommended as single-modality for early (T1N0 and T2N0) disease. For advanced stage disease standard therapeutic regimes include combined therapies as (chemo)radiotherapy with or without neck dissection, or surgical resection with reconstruction and postoperative (chemo)radiotherapy as required. Patients who are unfit to receive chemoradiation can be treated with a combination of cetuximab, an antibody inhibiting aberrant EGFR signalling, with locoregional radiotherapy.

In patients with advanced OPSCC chemoradiation therapy has an improved 5 -year survival of $8 \%$ compared to radiotherapy alone. Despite the efficacy of this therapy, especially in HPV-positive patients, it does increase acute and late toxic effects, including renal failure, hearing loss, dysphagia requiring long-term gastrostomy tube dependence, neuropathy, and osteoradionecrosis, when compared to radiotherapy alone. ${ }^{77}$ These toxic effects have a major influence on the patients' quality of life and have resulted in the search for equally (or even more) effective therapies with fewer adverse effects.

Given the different clinical behaviour, response to therapy, and favourable outcome for HPV-positive OPSCC, de-intensification of therapy has seriously been considered in recent years for this patient group. However, also in HPV-positive patients therapy fails in $10 \%-20 \%$ of cases, $50 \%$ of which caused by the occurrence of distant metastases. ${ }^{32,78}$ Therefore developing new treatment options for these patients is highly warranted. 
Treatment de-intensification strategies for HPV-positive OPSCC include reduced radiotherapy dose, radiotherapy alone rather than concurrent chemoradiation therapy, immunomodulating, antiviral, and targeted therapy. Treatment selection should be based on efficacy (tumour control), acute and late treatment toxicity and costs to patients and society. Therefore, several potential treatment options for HPV-positive OPSCC have been reviewed, some of which I will discuss below. ${ }^{79,80}$

\section{Reduction of the radiotherapy dose}

One of the possibilities to decrease toxicity is to reduce the standard dose of radiotherapy (70 Gy). Two phase II studies are being undertaken to investigate this option. ${ }^{80}$ One is a study from the Eastern Cooperative Oncology Group ECOG 1308 that recruited 90 HPV-positive stage III and IV OPSCC patients, receiving induction chemotherapy. Patients that achieved a complete response after restaging received a reduced radiation dose up to $54 \mathrm{~Gy}$ and cetuximab, in contrast to patients with a partial or no response, receiving the standard radiotherapy dose and cetuximab. Another study is the one from Mehrota et al. recruiting HPV-positive T1-3/N1-2 OPSCC patients having less than 10 packyears of smoking. In this trial patients receive induction chemotherapy and, after restaging, a reduced dose of radiotherapy with 66 Gy with or without chemotherapy for complete or partial responders, or standard chemoratiation therapy for non-responders or patients having progressive disease. Results from both studies can be expected in the following years. ${ }^{80}$

\section{Radiotherapy alone instead of chemoradiation}

In an HPV-positive low risk OPSCC patient group ${ }^{32}$ O' Sullivan et al ${ }^{81}$ found that (in most cases accelerated) RT alone and CRT were equally effective in terms of distant control for patients with T1-3 and N0-2a tumour stage or less than 10 pack-years N2b patients. However, this finding still needs to be validated in a clinical trial setting.

In another $\mathrm{p} 16^{\mathrm{INK} 4 \mathrm{~A}}$ positive OPSCC patient population, Sinha et al. ${ }^{82}$ showed that, in case of extracapsular spread after surgical resection, CRT did not improve DFS compared to RT alone, indicating that RT alone may be sufficient in these cases. 


\section{Targeted Therapy}

\section{EGFR-inhibitors}

A therapeutic alternative for HPV-positive OPSCC is the replacement of cisplatin with cetuximab, a monoclonal antibody against EGFR, for chemoradiation. Cisplatin is still considered the gold standard for chemoradiation, but cetuximab may be less toxic with potentially equal therapeutic results. Despite the fact that in OPSCC, in general, an inverse association between HPV-positivity and EGFR expression has been described, ${ }^{27,46,63}$ the performed study in chapter 6 showed an EGFR overexpression in more than $2 / 3$ of advanced HPV-positive OPSCC cases. It will be interesting to analyze if for these HPV-positive EGFR-overexpressing cases cetuximab is an efficient therapy, although the efficacy may be limited because of the deregulation of the cell cycle by the virus. Two large multicentre studies have been initiated to prospectively analyze this alternative for deintensification of therapy: a) the RTOG1016 trial in the USA, a phase III multicenter clinical trial, comparing weekly cetuximab-based chemoradiation with standard-dose cisplatin-based chemoradiation in patients with HPV-positive OPSCC, with overall survival as its primary outcome; b) the De-ESCALaTE HPV trial (Determination of Epidermal growth factor receptor inhibitor (cetuximab) versus Standard Chemotherapy (cisplatin) early And Late Toxicity Events in Human Papillomavirus-positive oropharyngeal SCC) in Europe, in which a similar comparison is being done with acute and late toxicity as the primary objective. Aim is to reduce toxicity in the cetuximab-based arm while maintaining favourable prognosis. ${ }^{1,74}$

\section{PIK3CA inhibitors}

In HPV-positive HNSCC a mutation in the oncogene PIK3CA is found in approximately $25 \%$ of cases. ${ }^{42-44}$ In addition, the study performed in chapter 4 showed that HPV-positive OPSCC have extra copy numbers of chromosome $3 q$ in up to two-thirds of cases, including the $3 q 26$ locus, harbouring the PIK3CA gene. Further studies are needed to better define the mechanism by which PIK3CA contributes to HPV-positive HNSCC development and to further explore PIK3CA and the PI3-kinase/PKB/AKT pathway as potential targets for therapeutic intervention in patients with HPV-induced carcinomas. 


\section{Immunomodulating therapies}

\section{Vaccination}

Therapeutic vaccination strategies aim to eliminate pre-existing lesions and even malignant tumours by generating cell-mediated immunity against the overexpressed foreign HPV oncoproteins, particularly E6 and E7. ${ }^{83,84}$ Clinical phase I therapeutic vaccine trials to evaluate the effectiveness in HNSCCpatients are being launched and such vaccination approaches may in the future be combined with traditional therapy modalities like surgery or chemoradiation. In contrast to therapeutic vaccines, two prophylactic HPV vaccines are currently on the market: Cervarix ${ }^{\circledR}$ (GlaxoSmithKline, Brentford, Middlesex, TW8 9GS, United Kingdom) and Gardasil (Merck, NJ, USA). Both vaccines protect against the HR-HPV-types 16 and 18 and have been FDA-approved to be used in girls and young women, ${ }^{85,86}$ whereas Gardasil囚, being a quadrivalent vaccine, also protects against LR-HPV6 and -11 and has also been approved for male use. ${ }^{87}$ Male vaccination can, in addition to protecting their partners from cervical cancer, protect males against genital warts, anal cancers, and may prevent other HPV-associated cancers, such as OPSCC. Whether or not HPV vaccination can indeed reduce the number of HPV-induced OPSCC will only become evident after several decades, because of the mean age of OPSCC development after the fifth decade.

\section{Conclusion}

The studies described in this thesis, as well as reports in the recent literature have made it very clear that HPV-positive and HPV-negative OPSCC are distinct clinicopathological and molecular entities. HPV-positivity may identify patients most likely to benefit from organ preservation therapy, and may justify a de-intensification of treatment approach even for patients with locoregionallyadvanced disease. However, other prognostic factors should be included in future risk models to better predict the risk of cancer specific death and to better stratify patients suitable for de-intensified cancer treatment. Furthermore, determination of HPV-status will play a future role in early cancer detection, tumour localization, post-treatment tumour surveillance and informed consultation of patients and their partners. 


\section{References}

1. Zandberg DP, Bhargava R, Badin S, Cullen KJ. The role of human papillomavirus in nongenital cancers. CA Cancer J Clin 2013;63:57-81.

2. Olthof NC, Straetmans JMJAA, Snoeck R, Ramaekers FCS, Kremer B, Speel EJM. Next-generation treatment strategies for human papillomavirus-related head and neck squamous cell carcinoma: where do we go? Rev Med Virol 2012;22: 88-105.

3. Mehanna H, Beech T, Nicholson T, El-Hariry I, McConkey C, Paleri V, Roberts S. Prevalence of human papillomavirus in oropharyngeal and nonoropharyngeal head and neck cancer-systematic review and meta-analysis of trends by time and region. Head Neck 2012;35:747-55.

4. van Houten VM, Snijders PJ, van den Brekel MW, Kummer JA, Meijer CJ, van Leeuwen B, Denkers F, Smeele LE, Snow GB, Brakenhoff RH. Biological evidence that human papillomaviruses are etiologically involved in a subgroup of head and neck squamous cell carcinomas. Int J Cancer 2001;93:232-5.

5. Wiest T, Schwarz E, Enders C, Flechtenmacher C, Bosch FX. Involvement of intact HPV16 E6/E7 gene expression in head and neck cancers with unaltered p53 status and perturbed pRb cell cycle control. Oncogene 2002;21:1510-7.

6. Weinberger PM, Yu Z, Haffty BG, Kowalski D, Harigopal M, Brandsma J, Sasaki C, Joe J, Camp RL, Rimm DL, Psyrri A. Molecular classification identifies a subset of human papillomavirus--associated oropharyngeal cancers with favorable prognosis. J Clin Oncol 2006;24:736-47.

7. Klussmann JP, Gültekin E, Weissenborn SJ, Wieland U, Dries V, Dienes HP, Eckel HE, Pfister HJ, Fuchs PG. Expression of p16 protein identifies a distinct entity of tonsillar carcinomas associated with human papillomavirus. Am J Pathol 2003;162:747-53.

8. Hafkamp HC, Mooren JJ, Claessen SM, Klingenberg B, Voogd AC, Bot FJ, Klussmann JP, Hopman AH, Manni JJ, Kremer B, Ramaekers FC, Speel EJ. P21 Cip1/WAF1 expression is strongly associated with HPV-positive tonsillar carcinoma and a favorable prognosis. Mod Pathol 2009;22:686-98.

9. Fregonesi PAG, Teresa DB, Duarte RA, Neto CB, de Oliveira MRB, Soares CP. p16(INK4A) immunohistochemical overexpression in premalignant and malignant oral lesions infected with human papillomavirus. J Histochem Cytochem 2003;51:1291-7.

10. Klaes R, Friedrich T, Spitkovsky D, Ridder R, Rudy W, Petry U, DallenbachHellweg G, Schmidt D, Knebel Doeberitz von M. Overexpression of p16(INK4A) as a specific marker for dysplastic and neoplastic epithelial cells of the cervix uteri. Int J Cancer 2001;92:276-84.

11. Yildiz IZ, Usubutun A, Firat P, Ayhan A, Kucukali T. Efficiency of immunohistochemical p16 expression and HPV typing in cervical squamous intraepithelial lesion grading and review of the p16 literature. Pathol Res Pract 2007;203:445-9.

12. Holzinger D, Schmitt M, Dyckhoff G, Benner A, Pawlita M, Bosch FX. Viral RNA patterns and high viral load reliably define oropharynx carcinomas with active HPV16 involvement. Cancer Res 2012;72:4993-5003.

13. Thavaraj S, Stokes A, Guerra E, Bible J, Halligan E, Long A, Okpokam A, Sloan P, Odell E, Robinson M. Evaluation of human papillomavirus testing for squamous cell carcinoma of the tonsil in clinical practice. J Clin Pathol 2011;64:308-12. 
14. Rietbergen MM, Leemans CR, Bloemena E, Heideman DAM, Braakhuis BJM, Hesselink AT, Witte BI, Baatenburg-De Jong RJ, Meijer CJLM, Snijders PJF, Brakenhoff $\mathrm{RH}$. Increasing prevalence rates of HPV attributable oropharyngeal squamous cell carcinomas in the Netherlands as assessed by a validated test algorithm. Int J Cancer 2013;132:1565-71.

15. Jordan RC, Lingen MW, Perez-Ordonez B, He X, Pickard R, Koluder M, Jiang B, Wakely P, Xiao W, Gillison ML. Validation of methods for oropharyngeal cancer HPV status determination in US cooperative group trials. Am J Surg Pathol 2012; 36:945-54.

16. Schlecht NF, Brandwein-Gensler M, Nuovo GJ, Li M, Dunne A, Kawachi N, Smith RV, Burk RD, Prystowsky MB. A comparison of clinically utilized human papillomavirus detection methods in head and neck cancer. Mod Pathol 2011;24: 1295-305.

17. Hafkamp HC, Manni JJ, Haesevoets A, Voogd AC, Schepers M, Bot FJ, Hopman AHN, Ramaekers FCS, Speel E-JM. Marked differences in survival rate between smokers and nonsmokers with HPV 16-associated tonsillar carcinomas. Int $J$ Cancer 2008;122:2656-64.

18. Klaes R, Benner A, Friedrich $T$, Ridder R, Herrington S, Jenkins D, Kurman RJ, Schmidt D, Stoler M, Knebel Doeberitz von M. p16INK4a immunohistochemistry improves interobserver agreement in the diagnosis of cervical intraepithelial neoplasia. Am J Surg Pathol 2002;26:1389-99.

19. Helt AM, Galloway DA. Mechanisms by which DNA tumor virus oncoproteins target the $\mathrm{Rb}$ family of pocket proteins. Carcinogenesis 2003;24:159-69.

20. Castillo JP, Kowalik TF. Human cytomegalovirus immediate early proteins and cell growth control. Gene 2002;290:19-34.

21. Rietbergen MM, Brakenhoff RH, Bloemena E, Witte BI, Snijders PJF, Heideman DAM, Boon D, Koljenovic S, Baatenburg de Jong RJ, Leemans CR. Human papillomavirus detection and comorbidity: critical issues in selection of patients with oropharyngeal cancer for treatment De-escalation trials. Ann Oncol 2013;24: 2740-5.

22. Cánepa ET, Scassa ME, Ceruti JM, Marazita MC, Carcagno AL, Sirkin PF, Ogara MF. INK4 proteins, a family of mammalian CDK inhibitors with novel biological functions. IUBMB Life 2007;59:419-26.

23. Krishnamurthy J, Torrice C, Ramsey MR, Kovalev GI, Al-Regaiey K, Su L, Sharpless NE. Ink4a/Arf expression is a biomarker of aging. J Clin Invest 2004; 114:1299-307.

24. Ben-Porath I, Weinberg RA. The signals and pathways activating cellular senescence. Int J Biochem Cell Biol 2005;37:961-76.

25. Kim Sh S-H, Kaminker $\mathrm{P}$, Campisi J. Telomeres, aging and cancer: in search of a happy ending. Oncogene 2002;21:503-11.

26. Huebbers CU, Preuss SF, Kolligs J, Vent J, Stenner M, Wieland U, Silling S, Drebber U, Speel E-JM, Klussmann JP. Integration of HPV6 and Downregulation of AKR1C3 Expression Mark Malignant Transformation in a Patient with JuvenileOnset Laryngeal Papillomatosis. PLoS ONE 2013;8:e57207.

27. Reimers N, Kasper HU, Weissenborn SJ, Stutzer H, Preuss SF, Hoffmann TK, Speel EJ, Dienes HP, Pfister HJ, Guntinas-Lichius O, Klussmann JP. Combined analysis of HPV-DNA, p16 and EGFR expression to predict prognosis in oropharyngeal cancer. Int J Cancer 2007;120:1731-8. 
28. Holzinger D, Flechtenmacher C, Henfling N, Kaden I, Grabe N, Lahrmann B, Schmitt M, Hess J, Pawlita M, Bosch FX. Identification of oropharyngeal squamous cell carcinomas with active HPV16 involvement by immunohistochemical analysis of the retinoblastoma protein pathway. Int J Cancer 2013;133:1389-99.

29. Rietbergen MM, Snijders PJF, Beekzada D, Braakhuis BJM, Brink A, Heideman DAM, Hesselink AT, Witte BI, Bloemena E, Baatenburg-De Jong RJ, Leemans CR, Brakenhoff RH. Molecular characterization of p16-immunopositive but HPV DNAnegative oropharyngeal carcinomas. Int J Cancer 2014;134:2366-72.

30. Smeets SJ, Hesselink AT, Speel E-JM, Haesevoets A, Snijders PJF, Pawlita M, Meijer CJLM, Braakhuis BJM, Leemans CR, Brakenhoff RH. A novel algorithm for reliable detection of human papillomavirus in paraffin embedded head and neck cancer specimen. Int J Cancer 2007;121:2465-72.

31. Shi W, Kato H, Perez-Ordonez B, Pintilie M, Huang S, Hui A, OSullivan B, Waldron J, Cummings B, Kim J, Ringash J, Dawson LA, et al. Comparative prognostic value of HPV16 E6 mRNA compared with in situ hybridization for human oropharyngeal squamous carcinoma. J Clin Oncol 2009;27:6213-21.

32. Ang KK, Harris J, Wheeler R, Weber R, Rosenthal DI, Nguyen-Tân PF, Westra $\mathrm{WH}$, Chung $\mathrm{CH}$, Jordan RC, Lu C, Kim H, Axelrod R, et al. Human papillomavirus and survival of patients with oropharyngeal cancer. N Engl J Med 2010;363:24-35.

33. Hafkamp HC, Manni JJ, Speel EJ. Role of human papillomavirus in the development of head and neck squamous cell carcinomas. Acta Otolaryngol 2004; 124:520-6.

34. Shaw R, Robinson M. The increasing clinical relevance of human papillomavirus type 16 (HPV-16) infection in oropharyngeal cancer. Br J Oral Maxillofac Surg 2011;49:423-9.

35. Chaturvedi AK, Anderson WF, Lortet-Tieulent J, Curado MP, Ferlay J, Franceschi S, Rosenberg PS, Bray F, Gillison ML. Worldwide trends in incidence rates for oral cavity and oropharyngeal cancers. J Clin Oncol 2013;31:4550-9.

36. D'Souza G, Kreimer AR, Viscidi R, Pawlita M, Fakhry C, Koch WM, Westra WH, Gillison ML. Case-control study of human papillomavirus and oropharyngeal cancer. N Engl J Med 2007;356:1944-56.

37. Gillison ML, D'Souza G, Westra W, Sugar E, Xiao W, Begum S, Viscidi R. Distinct risk factor profiles for human papillomavirus type 16-positive and human papillomavirus type 16-negative head and neck cancers. J Natl Cancer Inst 2008; 100:407-20.

38. Forastiere A, Koch W, Trotti A, Sidransky D. Head and neck cancer. N Engl J Med 2001;345:1890-900.

39. Hafkamp HC, Speel EJM, Haesevoets A, Bot FJ, Dinjens WNM, Ramaekers FCS, Hopman AHN, Manni JJ. A subset of head and neck squamous cell carcinomas exhibits integration of HPV 16/18 DNA and overexpression of p16INK4A and p53 in the absence of mutations in p53 exons 5-8. Int J Cancer 2003;107:394-400.

40. Smeets SJ, Braakhuis BJ, Abbas S, Snijders PJ, Ylstra B, van de Wiel MA, Meijer GA, Leemans CR, Brakenhoff RH. Genome-wide DNA copy number alterations in head and neck squamous cell carcinomas with or without oncogene-expressing human papillomavirus. Oncogene 2006;25:2558-64.

41. Dahlgren L, Mellin H, Wangsa D, Heselmeyer-Haddad K, Bjornestal L, Lindholm J, Munck-Wikland E, Auer G, Ried T, Dalianis T. Comparative genomic hybridization analysis of tonsillar cancer reveals a different pattern of genomic imbalances in human papillomavirus-positive and -negative tumors. Int J Cancer 2003;107:244-9. 
42. Agrawal N, Frederick MJ, Pickering CR, Bettegowda C, Chang K, Li RJ, Fakhry C, Xie TX, Zhang J, Wang J, Zhang N, El-Naggar AK, et al. Exome Sequencing of Head and Neck Squamous Cell Carcinoma Reveals Inactivating Mutations in NOTCH1. Science 2011;333:1154-7.

43. Stransky N, Egloff AM, Tward AD, Kostic AD, Cibulskis K, Sivachenko A, Kryukov GV, Lawrence MS, Sougnez C, McKenna A, Shefler E, Ramos AH, et al. The Mutational Landscape of Head and Neck Squamous Cell Carcinoma. Science 2011;333:1157-60.

44. Nichols AC, Palma DA, Chow W, Tan S, Rajakumar C, Rizzo G, Fung K, Kwan K, Wehrli B, Winquist E, Koropatnick J, Mymryk JS, et al. High frequency of activating PIK3CA mutations in human papillomavirus-positive oropharyngeal cancer. JAMA Otolaryngol Head Neck Surg 2013;139:617-22.

45. Bose P, Brockton NT, Dort JC. Head and neck cancer: from anatomy to biology. Int J Cancer 2013;133:2013-23.

46. Lassen $P$. The role of Human papillomavirus in head and neck cancer and the impact on radiotherapy outcome. Radiotherapy and Oncology 2010;95:371-80.

47. Wilson GA, Lechner M, Köferle A, Caren H, Butcher LM, Feber A, Fenton T, Jay A, Boshoff $\mathrm{C}$, Beck S. Integrated virus-host methylome analysis in head and neck squamous cell carcinoma. Epigenetics 2013;8.

48. Kostareli E, Holzinger D, Bogatyrova O, Hielscher T, Wichmann G, Keck M, Lahrmann B, Grabe N, Flechtenmacher C, Schmidt CR, Seiwert T, Dyckhoff G, et al. HPV-related methylation signature predicts survival in oropharyngeal squamous cell carcinomas. J Clin Invest 2013;123:2488-501.

49. Park I-S, Chang X, Loyo M, Wu G, Chuang A, Kim MS, Chae YK, Lyford-Pike S, Westra WH, Saunders JR, Sidransky D, Pai SI. Characterization of the methylation patterns in human papillomavirus type 16 viral DNA in head and neck cancers. Cancer Prev Res (Phila) 2011;4:207-17.

50. Lajer CB, Garnæs E, Friis-Hansen L, Norrild B, Therkildsen MH, Glud M, Rossing M, Lajer H, Svane D, Skotte L, Specht L, Buchwald C, et al. The role of miRNAs in human papilloma virus (HPV)-associated cancers: bridging between HPV-related head and neck cancer and cervical cancer. Br J Cancer 2012;106:1526-34.

51. Wald Al, Hoskins EE, Wells SI, Ferris RL, Khan SA. Alteration of microRNA profiles in squamous cell carcinoma of the head and neck cell lines by human papillomavirus. Head Neck 2011;33:504-12.

52. Hui ABY, Lin A, Xu W, Waldron L, Perez-Ordonez B, Weinreb I, Shi W, Bruce J, Huang SH, OSullivan B, Waldron J, Gullane P, et al. Potentially prognostic miRNAs in HPV-associated oropharyngeal carcinoma. Clin Cancer Res 2013;19:2154-62.

53. Rampias T, Sasaki C, Psyrri A. Molecular mechanisms of HPV induced carcinogenesis in head and neck. Oral Oncol 2014;50:356-63.

54. de Jong MC, Pramana J, Knegjens JL, Balm AJM, van den Brekel MWM, Hauptmann M, Begg AC, Rasch CRN. HPV and high-risk gene expression profiles predict response to chemoradiotherapy in head and neck cancer, independent of clinical factors. Radiother Oncol 2010;95:365-70.

55. Slebos RJC, Yi Y, Ely K, Carter J, Evjen A, Zhang X, Shyr Y, Murphy BM, Cmelak AJ, Burkey BB, Netterville JL, Levy $S$, et al. Gene expression differences associated with human papillomavirus status in head and neck squamous cell carcinoma. Clin Cancer Res 2006;12:701-9.

56. Schlecht N, Burk R, Adrien L, Dunne A, Kawachi N, Sarta C, Chen Q, BrandweinGensler M, Prystowsky M, Childs G, Smith R, Belbin T. Gene expression profiles in HPV-infected head and neck cancer. J Pathol 2007;213:283-93. 
57. Martinez I, Wang J, Hobson KF, Ferris RL, Khan SA. Identification of differentially expressed genes in HPV-positive and HPV-negative oropharyngeal squamous cell carcinomas. European Journal of Cancer 2007;43:415-32.

58. Ward MJ, Thirdborough SM, Mellows T, Riley C, Harris S, Suchak K, Webb A, Hampton C, Patel NN, Randall CJ, Cox HJ, Jogai S, et al. Tumour-infiltrating lymphocytes predict for outcome in HPV-positive oropharyngeal cancer. $\mathrm{Br} J$ Cancer 2013;110:489-500.

59. Lyford-Pike S, Peng S, Young GD, Taube JM, Westra WH, Akpeng B, Bruno TC, Richmon JD, Wang H, Bishop JA, Chen L, Drake CG, et al. Evidence for a role of the PD-1:PD-L1 pathway in immune resistance of HPV-associated head and neck squamous cell carcinoma. Cancer Res 2013;73:1733-41.

60. Hausen zur H. Papillomaviruses and cancer: from basic studies to clinical application. Nat Rev Cancer 2002;2:342-50.

61. Klussmann JP, Mooren JJ, Lehnen M, Claessen SMH, Stenner M, Huebbers CU, Weissenborn SJ, Wedemeyer I, Preuss SF, Straetmans JMJAA, Manni JJ, Hopman AHN, et al. Genetic Signatures of HPV-related and Unrelated Oropharyngeal Carcinoma and Their Prognostic Implications. Clinical Cancer Research 2009;15:1779-86.

62. Mooren JJ, Kremer B, Claessen SMH, Voogd AC, Bot FJ, Peter Klussmann J, Huebbers CU, Hopman AHN, Ramaekers FCS, Speel E-JM. Chromosome stability in tonsillar squamous cell carcinoma is associated with HPV16 integration and indicates a favorable prognosis. Int J Cancer 2013;132:1781-9.

63. Kumar B, Cordell KG, Lee JS, Worden FP, Prince ME, Tran HH, Wolf GT, Urba SG, Chepeha DB, Teknos TN, Eisbruch A, Tsien Cl, et al. EGFR, p16, HPV Titer, $\mathrm{Bcl}-\mathrm{xL}$ and $\mathrm{p} 53$, sex, and smoking as indicators of response to therapy and survival in oropharyngeal cancer. J Clin Oncol 2008;26:3128-37.

64. Fakhry C, Westra WH, Li S, Cmelak A, Ridge JA, Pinto H, Forastiere A, Gillison ML. Improved survival of patients with human papillomavirus-positive head and neck squamous cell carcinoma in a prospective clinical trial. $J$ Natl Cancer Inst 2008;100:261-9.

65. Straetmans JMJAA, Olthof N, Mooren JJ, de Jong J, Speel E-JM, Kremer B. Human papillomavirus reduces the prognostic value of nodal involvement in tonsillar squamous cell carcinomas. The Laryngoscope 2009;119:1951-7.

66. Lassen P, Eriksen JG, Hamilton-Dutoit S, Tramm T, Alsner J, Overgaard J. Effect of HPV-associated p16INK4A expression on response to radiotherapy and survival in squamous cell carcinoma of the head and neck. J Clin Oncol 2009;27:1992-8.

67. Rieckmann T, Tribius S, Grob TJ, Meyer F, Busch C-J, Petersen C, Dikomey E, Kriegs M. HNSCC cell lines positive for HPV and p16 possess higher cellular radiosensitivity due to an impaired DSB repair capacity. Radiother Oncol 2013; 107:242-6.

68. Abdulkarim B, Sabri S, Deutsch E, Chagraoui H, Maggiorella L, Thierry J, Eschwege F, Vainchenker W, Chouaïb S, Bourhis J. Antiviral agent Cidofovir restores p53 function and enhances the radiosensitivity in HPV-associated cancers. Oncogene 2002;21:2334-46.

69. Rampias T, Sasaki C, Weinberger P, Psyrri A. E6 and e7 gene silencing and transformed phenotype of human papillomavirus 16-positive oropharyngeal cancer cells. J Natl Cancer Inst 2009;101:412-23. 
70. Gillison ML, Koch WM, Capone RB, Spafford M, Westra WH, Wu L, Zahurak ML, Daniel RW, Viglione M, Symer DE, Shah KV, Sidransky D. Evidence for a causal association between human papillomavirus and a subset of head and neck cancers. J Natl Cancer Inst 2000;92:709-20.

71. Maxwell JH, Kumar B, Feng FY, Worden FP, Lee JS, Eisbruch A, Wolf GT, Prince ME, Moyer JS, Teknos TN, Chepeha DB, McHugh JB, et al. Tobacco use in human papillomavirus-positive advanced oropharynx cancer patients related to increased risk of distant metastases and tumor recurrence. Clin Cancer Res 2010;16: 1226-35.

72. Straetmans J, Vent J, Lacko M, Speel E-J, Huebbers C, Semrau R, Hoebers F, Mujagic Z, Klussmann JP, Preuss SF, Kremer B. Management of neck metastases of unknown primary origin united in two European centers. European Archives of Oto-Rhino-Laryngology 2014;:1-11.

73. Nguyen NP, Ly BH, Betz M, Vinh-Hung V. Importance of age as a prognostic factor for tonsillar carcinoma. Ann Surg Oncol 2010;17:2570-7.

74. Brakenhoff RH. Potentially novel options for treatment of HPV-attributable head and neck cancer. Cell Cycle 2013;12:1020-1.

75. Grégoire V, Lefebvre J-L, Licitra L, Felip E, EHNS-ESMO-ESTRO Guidelines Working Group. Squamous cell carcinoma of the head and neck: EHNS-ESMOESTRO Clinical Practice Guidelines for diagnosis, treatment and follow-up. Ann. Oncol.2010;21 Suppl 5:v184-6.

76. Bernier J, Schneider D. Cetuximab combined with radiotherapy: an alternative to chemoradiotherapy for patients with locally advanced squamous cell carcinomas of the head and neck? Eur J Cancer 2007;43:35-45.

77. Machtay M, Moughan J, Trotti A, Garden AS, Weber RS, Cooper JS, Forastiere A, Ang KK. Factors associated with severe late toxicity after concurrent chemoradiation for locally advanced head and neck cancer: an RTOG analysis. $J$ Clin Oncol 2008;26:3582-9.

78. Huang SH, Perez-Ordonez B, Weinreb I, Hope A, Massey C, Waldron JN, Kim J, Bayley AJ, Cummings B, Cho BCJ, Ringash J, Dawson LA, et al. Natural course of distant metastases following radiotherapy or chemoradiotherapy in HPV-related oropharyngeal cancer. Oral Oncol 2013;49:79-85.

79. Olthof NC, Straetmans JMJAA, Snoeck R, Ramaekers FCS, Kremer B, Speel EJM. Next-generation treatment strategies for human papillomavirus-related head and neck squamous cell carcinoma: where do we go? Rev Med Virol 2012;22: 88-105.

80. Kofler B, Laban S, Busch CJ, Lörincz B, Knecht R. New treatment strategies for HPV-positive head and neck cancer. Eur Arch Otorhinolaryngol 2014;271: 1861-7

81. OSullivan B, Huang SH, Siu LL, Waldron J, Zhao H, Perez-Ordonez B, Weinreb I, Kim J, Ringash J, Bayley A, Dawson LA, Hope A, et al. Deintensification candidate subgroups in human papillomavirus-related oropharyngeal cancer according to minimal risk of distant metastasis. J Clin Oncol 2013;31:543-50.

82. Sinha P, Lewis JS, Piccirillo JF, Kallogjeri D, Haughey BH. Extracapsular spread and adjuvant therapy in human papillomavirus-related, p16-positive oropharyngeal carcinoma. Cancer 2012;118:3519-30.

83. Kenter GG, Welters MJP, Valentijn ARPM, Lowik MJG, Berends-van der Meer DMA, Vloon APG, Essahsah F, Fathers LM, Offringa R, Drijfhout JW, Wafelman AR, Oostendorp J, et al. Vaccination against HPV-16 oncoproteins for vulvar intraepithelial neoplasia. N Engl J Med 2009;361:1838-47. 
84. Wu A, Zeng Q, Kang TH, Peng S, Roosinovich E, Pai SI, Hung C-F. Innovative DNA vaccine for human papillomavirus (HPV)-associated head and neck cancer. Gene Ther 2011;18:304-12.

85. Centers for Disease Control and Prevention (CDC). FDA licensure of bivalent human papillomavirus vaccine (HPV2, Cervarix) for use in females and updated HPV vaccination recommendations from the Advisory Committee on Immunization Practices (ACIP). MMWR Morb Mortal Wkly Rep 2010;59:626-9.

86. Markowitz LE, Dunne EF, Saraiya M, Lawson HW, Chesson H, Unger ER, Centers for Disease Control and Prevention (CDC), Advisory Committee on Immunization Practices (ACIP). Quadrivalent Human Papillomavirus Vaccine: Recommendations of the Advisory Committee on Immunization Practices (ACIP). MMWR Recomm Rep 2007;56:1-24.

87. Centers for Disease Control and Prevention (CDC). FDA licensure of quadrivalent human papillomavirus vaccine (HPV4, Gardasil) for use in males and guidance from the Advisory Committee on Immunization Practices (ACIP). MMWR Morb Mortal Wkly Rep 2010;59:630-2. 


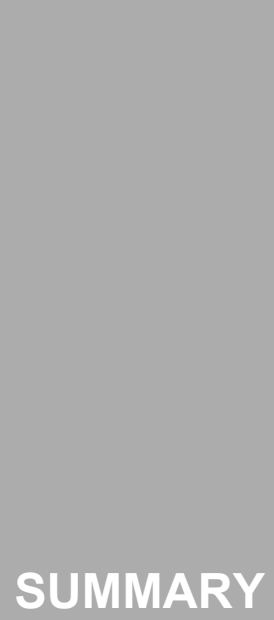




\section{Summary}

In chapter 1 a general introduction is provided, in which head and neck carcinogenesis, its epidemiology and the role of oncogenic HPV-infection in oropharyngeal squamous cell carcinoma (OPSCC), is reviewed. Particularly, the incidence of HPV-positive OPSCC has increased significantly worldwide over the last decades. In this context the influence of different HPV detection methods on supposed incidence rates is discussed. An overview of HPVsubtypes and HPV-induced carcinogenesis is provided, including the process in which viral oncoproteins affect essential cellular processes, such as the cell cycle and apoptosis. By this means, it becomes obvious that HPV-positive OPSCC have to be regarded a separate tumour entity with differing molecular and clinical characteristics. The aims and outline of the present thesis are described in the end of the chapter.

Because the cyclin dependent kinase inhibitor $\mathrm{p} 16^{\mathrm{INK} 4 \mathrm{~A}}$ is active in HPV-positive OPSCC, but often deleted or inactivated in HPV-negative tumours, it is of great scientific and clinical interest to see whether or not immunohistochemical $\mathrm{p} 16^{\text {INK4A }}$ staining is a reliable surrogate marker for the presence of both low-risk (LR) and high-risk (HR)-HPV in benign and (pre)malignant head and neck lesions. Therefore, in chapter 2, p16 ${ }^{\mathrm{INK} 4 \mathrm{~A}}$ immunohistochemistry was performed on paraffin-embedded tissue sections of 162 OPSCC, 14 tonsillar and 23 laryngeal dysplasias, and 20 tonsillar and 27 laryngeal papillomas, and correlated to HPV-status. PCR, enzyme-immunoassay and FISH analyses were used to assess HPV-presence and type. P16 ${ }^{\text {INK4A }}$ immunostaining patterns were first scored on a semiquantative scale: score $0(<5 \%$ of cells being $\mathrm{p} 16^{\mathrm{INK} 4 \mathrm{~A}}$ positive) to score 3 (>25\% positive cells). In addition, $\mathrm{p} 16^{\mathrm{INK} 4 \mathrm{~A}}$ staining patterns were scored according to the 'block-type' immunopositivity approach, defined as $\mathrm{p} 16^{\mathrm{INK} 4 \mathrm{~A}}$ being block positive if continuous (>70\%) strong nuclear with or without cytoplasmic staining is present (in all head and neck lesions) and staining is observed in the basal cell layer with extension upwards (in the benign and premalignant lesions). Thirty-one percent of OPSCC and $71 \%$ of tonsillar dysplasias were HPV16-positive. Sixteen percent of the laryngeal dysplasias and $96 \%$ of the laryngeal papillomas were positive for HPV6 or -11 and surprisingly all tonsillar papillomas were HPV-negative. We hypothesize that this HPV-negativity is caused by elimination of the virus by the immune system with persistence of the lesions, or by the fact that other viruses, yet to be discovered, play an etiological role in the development of the tonsillar papillomas. P16 ${ }^{\mathrm{INK} 4 \mathrm{~A}}$ immunohistochemistry revealed a strong (score 3) and block-positive nuclear and cytoplasmic staining in 50 out of 51 HPV16positive and 5 out of $111 \mathrm{HPV}$-negative OPSCC, resulting in a highly significant correlation with HPV-positivity. All HPV16-positive tonsillar dysplasia samples 
also showed a strong (score 3) p16 ${ }^{\text {INK4A }}$ expression, 8 of these being blockpositive. In contrast, highly variable staining patterns were detected in the papillomas and laryngeal dysplasias, irrespective of HPV-status. These results indicate that a strong nuclear and cytoplasmic $\mathrm{p} 16^{\mathrm{INK} 4 \mathrm{~A}}$ immunostaining pattern can indeed accurately predict the presence of HR-HPV16 in OPSCC and tonsillar dysplasias, with a proposed cut-off level of $70 \% \mathrm{p} 16^{\text {INK4A }}$ positive cells. In the other premalignant and benign head and neck lesions, however, caution is recommended when using this surrogate marker for HPV-infection.

Literature has shown that the HPV-oncogenes E6 and E7 inactivate p53 and $\mathrm{pRb}$, respectively, leading to disruption of cell cycle regulation and of the apoptotic pathway. Chapter 3 evaluates the expression and the prognostic value of key cell cycle proteins in the pRb and p53 pathways in both HPV16positive and -negative tonsillar squamous cell carcinoma (TSCC). Using immunohistochemistry, 77 TSCC with known HPV16-status (previously determined by HPV-specific PCR and FISH) and clinical outcome were analyzed for expression of proteins in the pRb pathway ( $\mathrm{p} 16^{\mathrm{INK} 4 \mathrm{~A}}$, cyclin D1, $\mathrm{p} 27^{\text {Kip1 }}$ and $\mathrm{pRb}$ ) and the $\mathrm{p} 53$ cascade (p14 ${ }^{\text {ARF }}$, MDM2, p53 and p2 $21^{\text {Cip 1/NAF1 }}$ ). Results were correlated with each other, with other risk factors like alcohol consumption and smoking, and with clinical and demographic patient data. Thirty-five percent of TSCC harboured integrated HPV16 and showed p16 INK4A overexpression. These tumours also exhibited overexpression of $\mathrm{p} 14^{\mathrm{ARF}}$ and $\mathrm{p} 21^{\text {Cip1WAF1 }}$, as well as downregulation of $\mathrm{pRb}$ and cyclin D1 and tended to be smaller as compared to the HPV-negative cases. Smoking and alcohol abuse were seen significantly more often in the HPV-negative patient group and there was a tendency towards more frequent accumulation of p53 in these tumours. HPV-positive tumours had a significant, favourable survival compared to the HPV-negative cases. The 5 years disease-specific survival was $31 \%$ for patients with an HPV-negative tumour and $69 \%$ for patients with an HPV-positive carcinoma. In multivariate regression analyses, smaller tumour size and strong $\mathrm{p} 21^{\mathrm{Cip} 1 \mathrm{NAF} 1}$ immunostaining appeared to be the most significant independent indicators for favourable prognosis in TSCC patients. These data indicate that the carcinogenesis in HPV-associated TSCC is different than that in tumours induced by smoking and/or alcohol consumption.

Results in previous studies have led to the hypothesis that at least two genetic routes underlie the development of OPSCC, as the development of smoking/ alcohol induced OPSCC appears to occur via accumulation of distinct (epi)genetic changes than HPV-induced tumours. In chapter 4 DNA copy number changes have been analyzed by genome-wide comparative genomic hybridization $(\mathrm{CGH})$ in a series of 60 OPSCC, of which HPV-status and clinical data were available. Results have been correlated with HPV-status, clinico- 
pathological characteristics, smoking and alcohol intake and disease outcome. HPV16-positivity was determined by means of HPV-specific PCR and FISH analysis and positive $\mathrm{p} 16^{\mathrm{INK} 4 \mathrm{~A}}$ immunostaining. Forty-nine percent of the tumours contained HPV16 and showed $\mathrm{p} 16^{\mathrm{INK} 4 \mathrm{~A}}$ overexpression. Two thirds of all OPSCC harboured gain at 3q26.3-qter irrespective of HPV-status. In $\mathrm{HPV}$-negative tumours this alteration was associated with advanced tumour stage. In comparison with HPV-positive OPSCC, the HPV-negative tumours harboured a higher number of chromosomal alterations and amplifications, as well as significantly more losses at $3 p, 5 q, 9 p, 15 q$ and $18 q$ and gains/amplifications at $11 q 13$, and, finally, less often $16 q$ losses and Xp gains. Survival analysis revealed a significantly better 5 year disease-free survival for HPV-positive OPSCC compared to HPV-negative cases ( $71 \%$ versus $46 \%$, respectively), whereas chromosome amplification was an unfavourable prognostic indicator. Interestingly, $16 \mathrm{q}$ loss, predominantly identified in HPV-positive OPSCC, was a strong indicator of favourable outcome and none of these patients had a tumour recurrence. These results indicate that HPV-positive and -negative OPSCC show different genetic signatures and most likely underlie differences in tumour development and progression. In addition, distinct chromosomal alterations have prognostic significance.

Chapter 5 describes the presence of chromosome instability in a series of primary TSCC in correlation to HPV16-status and patient survival. Previous data from cellular model systems are controversial concerning this relation. Furthermore, we were able to select 8 additional HPV-positive tonsillar dysplasias, 7 of which were found adjacent to a TSCC, for comparison of chromosomal (in)stability and the physical status of HPV. Seventy-seven TSCC, with known HPV16-status and clinical outcome, were analyzed by FISH, using chromosome 1- and 7-specific centromere DNA probes, to detect chromosome instability. Forty-two percent of tumours showed HPV16integration and $\mathrm{p} 16^{\mathrm{INK} 4 \mathrm{~A}}$ overexpression. Disomy for chromosome 1 and 7 was significantly more often observed in HPV-positive TSCC compared to the HPV-negative cases (19 out of 32 tumours versus 10 out of 45 tumours, respectively). Aneusomy correlated significantly with HPV-negative TSCC, tobacco- and alcohol consumption and a higher T-stage. Strong p53 immunostaining was also associated with HPV-negative tumours and smoking and/or alcohol abuse, but not with aneusomy and T-stage. In the dysplasias an identical HPV and chromosome copy number status was identified as in the adjacent tumours. The disease specific survival after 5 years was significantly better for patients with an HPV-positive carcinoma compared to the HPV-negative TSCC group ( $30 \%$ versus $74 \%$, respectively). Chromosome instability was a significant indicator for unfavourable prognosis in the total 
TSCC group, but was an even stronger unfavourable prognosticator in the HPV-positive patient group.

Chapter 6 outlines the incidence and predictive value of HPV-presence and EGFR expression in a series of advanced OPSCC $(n=111)$ and hypopharyngeal squamous cell carcinomas (HPSCC, $n=46$ ), all treated with concurrent radiotherapy and chemotherapy (cisplatin). Previous studies that analyzed EGFR expression in relation to survival in head and neck carcinomas observed different outcomes. In the present study HPV-positivity was determined by means of HPV16-specific FISH-analysis in all tumour sections and HPV-specific PCR in 10 cases. Tissue microarrays of tumour specimens were subjected to $\mathrm{p} 16^{\mathrm{INK} 4 \mathrm{~A}}$ and EGFR immunohistochemistry. Thirty-seven out of $111(33 \%)$ OPSCC showed strong p16 $6^{\text {INK4A }}$ immunostaining in more than $70 \%$ of tumour cells. Thirty-five of these 37 cases contained HPV 16 assessed by FISH analysis. The 2 p16 ${ }^{\text {INK4A }}$ positive, HPV16 FISH-negative cases proved to contain HPV33 DNA upon PCR analyses. The HPV-positive OPSCC group showed a significantly higher male-female ratio and these patients were less often cigarette smokers than patients with an HPV-negative tumour. $73 \%$ of HPV-positive OPSCC were also EGFR positive compared to $64 \%$ EGFR positive cases in the HPV-negative group (no significant difference). HPV-positivity was associated with the occurrence of less locoregional recurrences, less distant metastases and a more favourable overall and disease free survival. No associations were found between EGFR expression and survival in the whole OPSCC group and in the HPV-negative group. Within the HPV-positive group, however, EGFR immunopositive tumours had a significantly worse survival than EGFR negative cases. Furthermore, 9 out of 31 smokers developed recurrent diseases versus 1 out of 6 non-smokers, but this difference was not significant. Only $1 \mathrm{HPSCC}(2 \%)$ was both $\mathrm{p} 16^{\mathrm{INK} 4 \mathrm{~A}}$ and HPV-positive. In addition to previous studies described in this thesis, the present study makes it more evident that HPV-positive tumours are not a homogenous group and do not all have a favourable treatment outcome.

Chapter 7 comprises the general discussion and the conclusion of the results described in this thesis. Moreover, findings are related to recent literature and future perspectives are discussed. 
SAMENVATTING

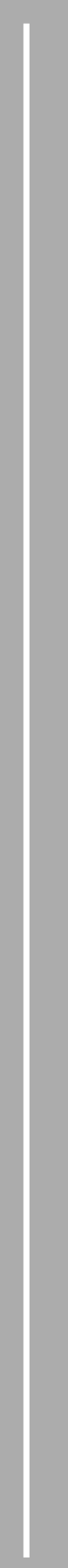




\section{Samenvatting}

Hoofdstuk 1 geeft een algemene inleiding met een overzicht van de carcinogenese van hoofd-hals kanker, de epidemiologie en de rol van oncogene HPV-infectie in de ontwikkeling van het plaveiselcelcarcinoom van de orofarynx (OPSCC). Met name de incidentie van HPV-positieve OPSCC is in de afgelopen decennia wereldwijd aanzienlijk toegenomen. In dit licht wordt de invloed van verschillende HPV-detectiemethoden op veronderstelde incidentiecijfers besproken. Er wordt een overzicht gegeven van de HPVsubtypes en HPV-geïnduceerde carcinogenese, inclusief het mechanisme waarmee virale oncoproteïnen essentiële cellulaire processen, zoals de celcyclus en apoptose, beïnvloeden. Hiermee wordt duidelijk dat HPV-positieve OPSCC beschouwd kunnen worden als een aparte tumor entiteit met verschillende moleculaire en klinische kenmerken. Tenslotte worden de doelen en de opzet van dit proefschrift beschreven.

Omdat de cycline afhankelijke kinase remmer $\mathrm{p} 16^{\text {INK4A }}$ actief is in HPVpositieve OPSCC, terwijl er vaak deletie of inactivatie plaatsvindt in HPVnegatieve tumoren, is het van groot wetenschappelijk en klinisch belang om te bepalen of immunohistochemische kleuring van $\mathrm{p} 16^{\mathrm{INK} 4 \mathrm{~A}}$ een betrouwbare surrogaat marker is voor de aanwezigheid van zowel laag-risico (LR) als hoogrisico (HR)-HPV in goedaardige en (pre)maligne hoofd-hals laesies. Daarom is in hoofdstuk $2 \mathrm{p} 16^{\text {INK4A }}$ immunohistochemie uitgevoerd op paraffineingebedde weefsel coupes van 162 OPSCC, 14 tonsil- en 23 larynx dysplasieën en 20 tonsil- en 27 larynx papillomen, en is dit gecorreleerd aan de HPV-status. PCR, enzym-immunoassay en FISH analyses werden gebruikt om de aanwezigheid van HPV en het HPV-type te bepalen. P16 ${ }^{\text {INKAA }}$ immunokleuringspatronen werden eerst gescoord op een semikwantitatieve schaal: score $0\left(<5 \%\right.$ van de cellen p16 ${ }^{\text {INK4A }}$ positief) tot score $3(>25 \%$ positieve cellen). Daarnaast werden de $\mathrm{p} 16^{\mathrm{INK} 4 \mathrm{~A}}$ kleuringspatronen gescoord volgens het principe van 'bloktype' immunopositiviteit, gedefinieerd als een blok-positieve p $16^{\text {INK4A }}$ kleuring wanneer er continue $(>70 \%)$ sterke nucleaire - met of zonder cytoplasmatische aankleuring - aanwezig is (in het geval van alle hoofd-hals laesies) en wanneer er kleuring wordt waargenomen in de basale cellaag met uitbreiding naar boven (in het geval van goedaardige en premaligne laesies). Eenendertig procent van de OPSCC en $71 \%$ van de tonsil dysplasieën waren HPV16-positief. Zestien procent van de larynx dysplasieën en $96 \%$ van de larynx papillomen waren positief voor HPV6 of -11 . Opvallend was dat alle tonsil papillomen HPV-negatief waren. Een mogelijke verklaring voor deze HPV-negativiteit is de eliminatie van het virus door het immuunsysteem met persisteren van de laesie of doordat andere, nog nader te bepalen, virussen een etiologische rol spelen in de ontwikkeling van de tonsil papillomen. 
$\mathrm{P} 16^{\text {INK4A }}$ immunohistochemie toonde een sterke (score 3) en blok-positieve nucleaire en cytoplasmatische kleuring in 50 van de 51 HPV16-positieve en 5 van de $111 \mathrm{HPV}$-negatieve OPSCC, resulterend in een zeer significante correlatie met HPV-positiviteit. Alle HPV16-positieve tonsil dysplasieën toonden ook een sterke (score 3) p16 ${ }^{\mathrm{INK} 4 \mathrm{~A}}$ expressie en 8 van deze waren ook blokpositief. Daarentegen werden zeer variabele kleuringpatronen gezien in de papillomen en larynx dysplasieën, ongeacht de HPV-status. Deze resultaten tonen aan dat een sterke nucleaire en cytoplasmatische p16 ${ }^{\text {INK4A }}$ immunokleuring inderdaad nauwkeurig de aanwezigheid van HR-HPV16 in OPSCC en tonsil dysplasieën kan voorspellen, met een voorgestelde afkapwaarde van $70 \% \mathrm{p} 16^{\mathrm{INK} 4 \mathrm{~A}}$ positieve cellen. In de overige premaligne en goedaardige hoofdhals laesies is voorzichtigheid geboden bij gebruik van deze surrogaat marker voor HPV-infectie.

De literatuur heeft aangetoond dat de HPV-oncogenen E6 en E7 zorgen voor inactivatie van p53 en pRb, resulterend in een verstoring van de celcyclus en de apoptose pathway. Hoofdstuk 3 onderzoekt de expressie en de prognostische waarde van de belangrijkste celcyclus eiwitten in de pRb en p53 pathways in zowel HPV16-positieve als -negatieve tonsillaire plaveiselcelcarcinomen (TSCC). Met behulp van immunohistochemie werd in 77 TSCC, met bekende HPV16-status (eerder bepaald door middel van HPV-specifieke $\mathrm{PCR}$ en FISH) en klinische uitkomstmaten, de expressie van eiwitten in de $\mathrm{pRb}$ pathway ( $\mathrm{p} 16^{\text {INK4A }}$, cycline $\mathrm{D} 1, \mathrm{p} 27^{\text {Kip } 1}$ en $\mathrm{pRb}$ ) en de $\mathrm{p} 53$ cascade $\left(\mathrm{p} 14^{\mathrm{ARF}}\right.$, MDM2, p53 en p21 ${ }^{\text {Cip1/NAF1 }}$ ) geanalyseerd. De resultaten werden gecorreleerd met elkaar, met risicofactoren zoals alcohol en roken en klinische en demografische patiëntgegevens. Vijfendertig procent van de TSCC had geïntegreerd HPV16 en toonde tevens $\mathrm{p} 16^{\mathrm{INK} 4 \mathrm{~A}}$ overexpressie. Deze tumoren lieten ook overexpressie van $\mathrm{p} 14^{\mathrm{ARF}}$ en $\mathrm{p} 21^{\mathrm{Cip} 1 / \text { WAF1 }}$ en downregulatie van $\mathrm{pRb}$ en cycline D1 zien en er was een tendens tot kleinere tumorafmetingen in vergelijking met de HPV-negatieve gevallen. Roken en alcoholmisbruik werden significant vaker gezien in de HPV-negatieve patiëntengroep en er was een tendens naar frequentere accumulatie van p53 in deze tumoren. HPV-positieve tumoren hadden een significant gunstigere overleving in vergelijking tot de HPV-negatieve gevallen. De ziektespecifieke overleving na 5 jaar was $31 \%$ voor patiënten met een HPV-negatieve tumor en $69 \%$ voor patiënten met HPVpositieve carcinomen. Uit multivariate regressie analyse bleek dat kleinere tumorgrootte en sterke p21 Cip1/NAF1 immunokleuring de belangrijkste onafhankelijke indicatoren waren voor een gunstige prognose in TSCC patiënten. Deze gegevens laten zien dat de carcinogenese bij HPVgeassocieerde TSCC anders is dan in door roken en/of alcohol geïnduceerde tumoren. 
Resultaten uit eerdere studies hebben geleid tot de hypothese dat tenminste twee genetische routes ten grondslag liggen aan de ontwikkeling van OPSCC, omdat de ontwikkeling van roken en/of alcohol geïnduceerde OPSCC lijkt op te treden via accumulatie van andere (epi)genetische veranderingen dan die van HPV-geïnduceerde tumoren. In hoofdstuk 4 werden veranderingen in DNA kopie aantallen geanalyseerd door genoombrede comparative genomic hybridization $(\mathrm{CGH})$ in een reeks van 60 OPSCC, waarvan de HPV-status en klinische gegevens al beschikbaar waren. De resultaten zijn gecorreleerd met HPV-status, clininicopathologische kenmerken, roken en alcoholgebruik en met ziekte uitkomst. HPV16-positiviteit werd bepaald door middel van HPVspecifieke PCR en FISH analyse en positieve $\mathrm{p} 16^{\text {INK4A }}$ immunokleuring. Negenenveertig procent van de tumoren bevatte HPV16 en toonde $p 16^{\text {INK4A }}$ overexpressie. Tweederde van alle OPSCC liet winst zien van 326.3-qter ongeacht de HPV-status. In HPV-negatieve tumoren was deze verandering geassocieerd met een verder gevorderd tumor stadium. In vergelijking tot HPVpositieve OPSCC hadden HPV-negatieve tumoren een groter aantal chromosomale afwijkingen en amplificaties, alsmede significant vaker verlies van $3 p, 5 q, 9 p, 15 q$ en $18 q$ en winst/ amplificaties van $11 q 13$ en ten slotte minder vaak $16 q$ verlies en $X p$ winst. Overlevingsanalyse toonde een significant betere 5-jaars ziektevrije overleving voor HPV-positieve OPSCC in vergelijking tot HPV-negatieve gevallen (respectievelijk $71 \%$ versus $46 \%$ ), terwijl chromosomale amplificatie een ongunstige prognostische factor was. Interessant was de observatie dat $16 q$ verlies, voornamelijk gevonden in HPVpositieve OPSCC, een sterke indicator voor een gunstige prognose was en dat geen van deze patiënten een tumorrecidief had. Deze resultaten laten zien dat HPV-positieve en -negatieve OPSCC verschillende genetische kenmerken hebben die waarschijnlijk ten grondslag liggen aan verschillen in tumor ontwikkeling en progressie. Bovendien hebben verschillende chromosomale afwijkingen prognostische betekenis.

In hoofdstuk 5 wordt de aanwezigheid van chromosomale instabiliteit in een serie primaire TSCC gecorreleerd met HPV16-status en patiëntenoverleving. Voorgaande data uit cellulaire modelsystemen zijn tegenstrijdig wat deze relatie betreft. Tevens zijn we in staat geweest om 8 extra HPV-positieve tonsil dysplasieën te selecteren, waarvan 7 werden gevonden naast een TSCC, voor een vergelijking van chromosomale (in)stabiliteit en de fysieke toestand van HPV. Zevenenzeventig TSCC, met bekende HPV16-status en klinische uitkomsten, werden geanalyseerd door middel van FISH met behulp van chromosoom 1- en 7-specifieke centromeer DNA-probes om chromosomale instabiliteit te detecteren. Tweeënveertig procent van de tumoren toonde HPV16-integratie en $\mathrm{p} 16^{\mathrm{INK} 4 \mathrm{~A}}$ overexpressie. Disomie voor chromosoom 1 en 7 werd significant vaker gezien in HPV-positieve TSCC in vergelijking tot de 
HPV-negatieve gevallen (respectievelijk 19 van de 32 versus 10 van de 45 tumoren). Aneusomie was significant gecorreleerd met HPV-negatieve TSCC, tabak- en alcoholgebruik en een hoger T-stadium. Ook sterke p53 immunokleuring was geassocieerd met HPV-negatieve tumoren en roken en/of alcohol misbruik, maar niet met aneusomie en T-stadium. In de dysplasieën werden identieke HPV-status en chromosomale kopie aantallen gezien als in de aangrenzende tumoren. De ziektespecifieke overleving na 5 jaar was significant beter voor patiënten met HPV-positieve carcinomen in vergelijking tot de HPV-negatieve TSCC groep (respectievelijk 30\% versus 74\%). Chromosomale instabiliteit was een significante indicator voor een ongunstige prognose in de totale TSCC groep, maar was zelfs een nog sterkere ongunstige voorspeller in de HPV-positieve patiënten groep.

Hoofdstuk 6 beschrijft de incidentie en de voorspellende waarde van de aanwezigheid van HPV en EGFR expressie in een serie vergevorderde OPSCC $(n=111)$ en plaveiselcelcarcinomen van de hypofarynx (HPSCC, $\mathrm{n}=46$ ), allemaal behandeld met gelijktijdige radiotherapie en chemotherapie (cisplatine). Eerdere studies die de relatie tussen EGFR expressie in hoofdhals carcinomen en overleving analyseerden, toonden verschillende uitkomsten. In de huidige studie werd HPV-positiviteit bepaald door middel van HPV16-specifieke FISH analyse in alle tumorcoupes en HPV-specifieke PCR in 10 gevallen. Op tissue microarrays van de tumor exemplaren werd $p 16^{\text {INKAA }}$ en EGFR immunohistochemie verricht. Zevenendertig van de 111 (33\%) OPSCC liet een sterke $\mathrm{p} 16^{\mathrm{INK} 4 \mathrm{~A}}$ immunokleuring zien in meer dan $70 \%$ van de tumorcellen. Vijfendertig van deze 37 gevallen bevatten HPV16, beoordeeld door middel van de FISH analyse. De 2 p16 $6^{\text {INK4A }}$ positieve, HPV16 FISHnegatieve casussen bleken HPV33-DNA te bevatten bij PCR-analyse. De HPVpositieve OPSCC groep toonde een significant hogere man-vrouw verhouding en deze patiënten waren minder vaak sigarettenrokers dan patiënten met een HPV-negatieve tumor. Drieënzeventig procent van de HPV-positieve OPSCC waren ook EGFR positief ten opzichte van 64\% EGFR positieve gevallen bij de HPV-negatieve groep (geen significant verschil). HPV-positiviteit was geassocieerd met het optreden van minder locoregionale recidieven, minder metastasen op afstand en een gunstigere algehele - en ziektevrije overleving. Er werden geen associaties gevonden tussen EGFR expressie en overleving in de hele OPSCC groep en in de HPV-negatieve groep. Binnen de HPVpositieve groep hadden EGFR immunopositieve tumoren echter een significant slechtere overleving dan EGFR negatieve gevallen. Bovendien ontwikkelden 9 van de 31 rokers een recidief van de ziekte versus 1 van de 6 niet-rokers, hoewel dit verschil niet significant was. Slechts 1 HPSCC (2\%) was zowel p16 ${ }^{\text {INK4A }}$ en HPV-positief. In aanvulling op eerdere studies beschreven in dit 
proefschrift, maakt de huidige studie duidelijk dat HPV-positieve tumoren geen homogene groep zijn en niet allemaal een gunstige therapie uitkomst hebben.

Hoofdstuk 7 bevat de algemene discussie en de conclusie van de in dit proefschrift beschreven resultaten. Bovendien zijn bevindingen vergeleken met de recente literatuur en worden toekomstperspectieven besproken. 


\section{VALORISATION ADDENDUM}

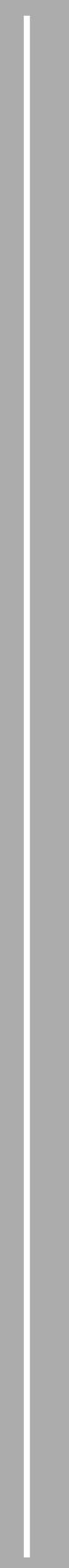




\section{Valorisation addendum}

\section{Relevance}

This thesis addresses the increasing health care problem of the rising incidence of oropharyngeal squamous cell carcinoma (OPSCC) over the last 20 years, as documented for, amongst others, the USA and Europe. ${ }^{1,2}$ Studies from the United States of America show a 5\% annual increase in (ageadjusted) incidence of OPSCC from 1973 to 2004, while a decrease is observed in the incidence of head and neck carcinoma in general, as a result of a decrease in smoking and alcohol abuse. ${ }^{3}$ This increase in OPSCC is attributed to infections with oncogenic human papillomavirus (HPV), in particular HPV-type 16. Some authors even claim that in the future all tonsillar squamous cell carcinomas will be HPV-positive, comparable to the situation with uterine cervical carcinoma. ${ }^{4}$ This indicates that in the future high-risk (HR)HPV-infection is expected to play an even more important role in head and neck carcinogenesis. HPV-positive OPSCC appears to be a separate entity compared to smoking and/or alcohol-induced tumours, both at the clinical and molecular level..$^{5-11}$ Patients with HPV-positive OPSCCs have a favourable prognosis, despite the fact that their tumours are often poorly differentiated and metastasized to lymph nodes at presentation., ${ }^{2,-14}$ Furthermore, TN(M) classification seems to be of less importance for the prognosis in the case of HPV-positive tumours. ${ }^{15}$

All these factors underscore the social relevance of my research, because clinicians can be better prepared on how to deal with this disease. Moreover, medical doctors can better inform OPSCC patients about their disease and prognosis. Although in the current guidelines for treatment of head and neck squamous cell carcinoma (HNSCC), HPV-status is not yet included for therapy selection, this may be expected in the near future. The nowadays-used therapies, including most often chemoradiation therapy in stage III and IV tumours, cause a high rate of co-morbidity and even mortality in some cases. Because of the favourable prognosis noted for HPV-positive OPSCC patients, a debate is ongoing whether or not patients with such tumours should be less intensively treated than patients with HPV-negative tumours. ${ }^{9}$ The aim of deintensification of therapy is to reduce toxicity with improved quality of life, but with an (at least) equal effect on clinical outcome. Possibilities for deintensification include lowering radiation dose, the choice for radiotherapy alone rather than in combination with chemotherapy, and targeted therapy with e.g. Cetuximab or PI3K/AKT/mTOR-pathway inhibitors. ${ }^{9}$

De-intensification of therapy should in my opinion, however, only be implemented for certain HPV-positive cancer patients, since the studies in this thesis, as well as dose of others have shown that not all HPV-positive tumours 
have a favourable prognosis. ${ }^{12,16}$ For example, HPV-positive tumours that are genetically instable, that show high EGFR expression levels and/or that are found in smokers, have a highly unfavourable prognosis. Therefore, other prognostic factors besides HPV-status should be included in future risk models to better predict the risk of cancer specific death and to better stratify patients suitable for de-intensified cancer treatment.

Finally, HPV-vaccination and education programs may in the future lead to prevention of HPV-induced OPSCC. As HPV is a sexually transmitted disease and in particular oral sex is a risk factor for HPV-positive OPSCC development, sex education can help in preventing this disease. Currently two prophylactic HPV-vaccines have been introduced: Cervarix $\circledast$ and Gardasil $\circledast$, both protecting against HR-HPV-types 16 and 18 and Gardasil also protecting against low-risk (LR)-HPV6 and -11. In the Netherlands vaccination is recommended for young women to prevent cervical cancer. Unfortunately, male vaccination is still not approved here, while it can, in addition to protecting their partners from cervical cancer, protect males against genital warts, anal cancers, and maybe OPSCC. Although it will last several decades to observe the efficacy of HPV-vaccination on OPSCC-development, I am strongly in favour of HPV-vaccination for young men.

This thesis has also economic relevance.

Firstly, the two most frequently used methods for the detection of HPV-DNA in clinical diagnosis and biomedical research, i.e., polymerase chain reaction (PCR)-based methods and fluorescence in situ hybridization (FISH), are relatively costly, technically demanding and require sophisticated laboratory facilities as well as experienced personnel. ${ }^{17}$ Therefore, immunohistochemical detection of $\mathrm{p} 16^{\mathrm{INK} 4 \mathrm{~A}}$ has been explored, which has been reported to be the most reliable surrogate marker for the presence of HR-HPV in OPSCC. ${ }^{18,19}$ The study performed in chapter 2 , but also my other studies, indicate that a strong nuclear and cytoplasmic $\mathrm{p} 16^{\mathrm{IKK} 4 \mathrm{~A}}$ immunostaining pattern indeed can accurately predict the presence of HR-HPV16 in OPSCC. However, since incidental $\mathrm{p} 16^{\mathrm{INK} 4 \mathrm{~A}}$ positive cases that are HPV-unrelated, have been reported, the presence of HPV always needs to be confirmed by applying HPV-specific FISH and/or DNA PCR, or RT-PCR analysis of E6/E7 transcripts after HPVtyping. In case of $\mathrm{p} 16^{\mathrm{INK} 4 \mathrm{~A}}$ negativity in OPSCC no further analyses are needed, thereby omitting the need for these more time-consuming and costly diagnostic procedures.

Secondly, the previously mentioned proposal of de-intensification of therapy of HPV-positive OPSCC may lead to less severe co-morbidities, thereby reducing the costs of treating therapy-induced side effects. Furthermore, if in the future an HPV-positive OPSCC patient may be treated equally effective with for example a lower dose of radiotherapy, or radiotherapy alone instead of 
chemoradation therapy, this will also lead to cost reduction for general healthcare.

\section{Target groups}

The results of my thesis are important to several groups of people, which will be summarized below.

The research is of interest to head and neck surgeons and radiotherapists, because these medical doctors are directly involved in diagnosing and treating patients with HNSCC. The present thesis provides further evidence for the heterogeneity of HNSCC and that HPV-positive and-negative OPSCC are separate entities, both clinically and molecularly. For a medical doctor it is crucial to be able to provide reliable information to patients about their disease and prognosis, and to better determine what treatment modalities are preferably being used for the different types of HNSCC.

The studies are also of high interest to pathologists, because they provide a definitive diagnosis of the tumour tissue to the medical practitioner. The increasing role of HPV in OPSCC development makes determining the HPVstatus more and more important. For this purpose my thesis and other studies warrant the introduction of $\mathrm{p} 16^{\mathrm{INK} 4 \mathrm{~A}}$ immunohistochemistry followed by HPVspecific PCR and/or FISH in daily practice.

Epidemiologists may be interested in my thesis, as it provides further information on incidence levels and survival rates of OPSCC patients in the Netherlands. The reported overall incidence of HPV in OPSCC ranges from less than $20 \%$ to more than $90 \%$ in the literature. ${ }^{4,20}$ Amongst others, geographical features, differences in tobacco and alcohol consumption, differences in sexual behaviour, sample preparation and also the type of HPVdetection methods, have been put forward as explanation for this variation. ${ }^{9}$

Pharmaceutical industries can benefit from my research, because a better understanding of the molecular characteristics of HPV-positive OPSCC may result in new opportunities for targeted therapies. Given the different clinical behaviour, response to therapy, and favourable outcome for patients with HPVpositive OPSCC, de-intensification of therapy is currently being investigated in this patient group. However, also in HPV-positive patients therapy fails in 10\%$20 \%$ of cases, $50 \%$ of which is caused by the occurrence of distant metastases. $^{12,21}$ Therefore, development of new treatment options for these patients is urgently required.

The benefit for the general population is that individuals can be better informed on risk factors for cancer development and how to prevent these. Most people are aware of the potentially adverse effects of smoking and alcohol consumption, whereas the result of sexual behaviour and HPV as a cause of OPSCC development is much less generally known. Because there is a correlation between patients with HPV-positive OPSCC and a higher number of 
sexual partners, particularly oral sex partners, ${ }^{22}$ education programs should include this risk behaviour as well.

And finally and most importantly, my research is of high relevance for OPSCC patients, because hopefully in the near future they can profit from optimal treatment with reduced adverse treatment effects, resulting in a better quality of life and an improved survival.

\section{Activities}

The results of my research can be directly implemented into the clinic, as pathologists can use the mentioned detection methods for HPV-detection in tumour tissue.

Furthermore, a better understanding of the mechanisms underlying cancer development and progression may lead to new opportunities to improve OPSCC treatment.

This thesis provides scientific evidence for the assumption that HPV-positive patient subgroups exist with a highly unfavourable prognosis for survival, which can be indentified by a number of specific parameters. Future studies conducting multivariate analyses on these parameters are highly warranted as this may lead to better risk-models for patient survival as compared to the currently ones proposed. ${ }^{12,16}$

\section{Innovation}

Although numerous studies analyzed the expression of $\mathrm{p} 16^{\mathrm{INK} 4 \mathrm{~A}}$ in HR- and LRHPV-associated cervical premalignancies, these data are scarce for premalignant and benign head and neck lesions. Therefore, the study in chapter 2 determined the usefulness of this biomarker in several additional lesions of the oropharynx and larynx besides OPSCC, i.e. papillomas and dysplasias. $\mathrm{P} 16^{\mathrm{INK} 4 \mathrm{~A}}$ immunohistochemical staining has shown to be valuable as surrogate marker for HR-HPV in OPSCC and tonsillar dysplasias.

By combining $\mathrm{p} 16^{\mathrm{INK} 4 \mathrm{~A}}$ immunohistochemistry with HPV-specific PCR and $\mathrm{FISH}$, it is now possible to identify the correct group of OPSCC in which oncogenic HPV actually plays an etiological role and to study this group in relation to HPV non-related OPSCC. This has resulted in several outcomes described in the different chapters of the present thesis:

Chapter 3 shows that HPV-positive tonsillar squamous cell carcinoma (TSCC) have different expression profiles of several cell cycle proteins involved in the

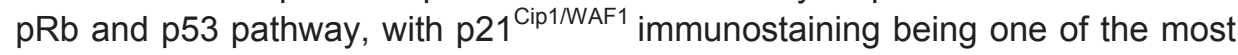
significant independent indicators for a favourable prognosis in TSCC patients.

Chapter 4 describes that HPV-positive OPSCC harbour different genetic signatures with distinct chromosomal alterations having prognostic significance. Chapter 5 provides evidence that HPV-positive TSCC show significantly more often chromosome stability. This was analysed in a series of primary TSCC 
and tonsillar dysplasias, whereas previous data from the literature are particularly based on cell model experiments. ${ }^{23-25}$ Furthermore, chromosome instability was a significant indicator for an unfavourable prognosis in the total TSCC group, but was an even stronger unfavourable prognosticator in the HPV-positive patient group.

Finally, in contrast to the previous chapters in which several treatment modalities are used, chapter 6 describes a group of OPSCC patients all treated with the same modality, i.e. concurrent radiotherapy and chemotherapy (cisplatin), and again shows that HPV-positivity is significantly associated with a favourable survival. However, within this HPV-positive group patients with an EGFR immunopositive tumour had a significantly worse survival compared to EGFR negative cases.

\section{Planning and production}

The goal of the present thesis was to gain more insight into the molecular and clinical differences between HPV-induced and smoking and/or alcohol induced OPSCC and how these differences relate to patient survival. Currently two large multicentre studies have been initiated to prospectively analyze alternatives for treatment de-intensification, i.e. a phase III multicenter clinical trial in the USA, named the RTOG1016 trial, and the De-ESCALaTE HPV trial in Europe, comparing Cetuximab-based chemoradiation with standard-dose cisplatin-based chemoradiation in patients with HPV-positive OPSCC. Aim of both studies is to reduce toxicity in the Cetuximab-based arm while maintaining favourable prognosis. ${ }^{1,26}$ An important conclusion made from the results from my studies is that a subgroup of HPV-positive OPSCC patients show unfavourable survival and likely will not profit from de-intensification of therapy. Rather, this group urgently needs new alternatives for therapy, which is also needed for HPV-negative HNSCC. Therefore, in the Maastricht University Medical Centre studies are ongoing to analyse the effects of PiK3/AKT/mTORpathway inhibitors and Cidofovir in HPV-positive and negative HNSCC cell lines. Future research is also needed to further optimize the currently proposed risk-models in which HPV-presence is already implemented. 


\section{References}

1. Zandberg DP, Bhargava R, Badin S, Cullen KJ. The role of human papillomavirus in nongenital cancers. CA Cancer J Clin 2013;63:57-81.

2. Chaturvedi AK, Anderson WF, Lortet-Tieulent J, Curado MP, Ferlay J, Franceschi S, Rosenberg PS, Bray F, Gillison ML. Worldwide trends in incidence rates for oral cavity and oropharyngeal cancers. J Clin Oncol 2013;31:4550-9.

3. Chaturvedi AK, Engels EA, Anderson WF, Gillison ML. Incidence trends for human papillomavirus-related and -unrelated oral squamous cell carcinomas in the United States. J Clin Oncol 2008;26:612-9.

4. Näsman A, Attner P, Hammarstedt L, Du J, Eriksson M, Giraud G, Ahrlund-Richter S, Marklund L, Romanitan M, Lindquist D, Ramqvist T, Lindholm J, et al. Incidence of human papillomavirus (HPV) positive tonsillar carcinoma in Stockholm, Sweden: an epidemic of viral-induced carcinoma? Int J Cancer 2009;125:362-6.

5. D'Souza G, Kreimer AR, Viscidi R, Pawlita M, Fakhry C, Koch WM, Westra WH, Gillison ML. Case-control study of human papillomavirus and oropharyngeal cancer. N Engl J Med 2007;356:1944-56.

6. Gillison ML, D'Souza G, Westra W, Sugar E, Xiao W, Begum S, Viscidi R. Distinct risk factor profiles for human papillomavirus type 16-positive and human papillomavirus type 16-negative head and neck cancers. J Natl Cancer Inst 2008; 100:407-20.

7. Forastiere A, Koch W, Trotti A, Sidransky D. Head and neck cancer. N Engl J Med 2001;345:1890-900.

8. Hafkamp HC, Speel EJM, Haesevoets A, Bot FJ, Dinjens WNM, Ramaekers FCS, Hopman AHN, Manni JJ. A subset of head and neck squamous cell carcinomas exhibits integration of HPV 16/18 DNA and overexpression of p16INK4A and p53 in the absence of mutations in p53 exons 5-8. Int J Cancer 2003;107:394-400.

9. Olthof NC, Straetmans JMJAA, Snoeck R, Ramaekers FCS, Kremer B, Speel EJM. Next-generation treatment strategies for human papillomavirus-related head and neck squamous cell carcinoma: where do we go? Rev Med Virol 2012;22: 88-105.

10. Braakhuis BJ, Snijders PJ, Keune WJ, Meijer CJ, Ruijter-Schippers HJ, Leemans $\mathrm{CR}$, Brakenhoff RH. Genetic patterns in head and neck cancers that contain or lack transcriptionally active human papillomavirus. J Natl Cancer Inst 2004;96: 998-1006.

11. Weinberger PM, Yu Z, Haffty BG, Kowalski D, Harigopal M, Brandsma J, Sasaki C, Joe J, Camp RL, Rimm DL, Psyrri A. Molecular classification identifies a subset of human papillomavirus--associated oropharyngeal cancers with favorable prognosis. J Clin Oncol 2006;24:736-47.

12. Ang KK, Harris J, Wheeler R, Weber R, Rosenthal DI, Nguyen-Tân PF, Westra $\mathrm{WH}$, Chung $\mathrm{CH}$, Jordan $\mathrm{RC}$, Lu C, Kim H, Axelrod R, et al. Human papillomavirus and survival of patients with oropharyngeal cancer. N Engl J Med 2010;363:24-35.

13. Hafkamp HC, Manni JJ, Speel EJ. Role of human papillomavirus in the development of head and neck squamous cell carcinomas. Acta Otolaryngol 2004;124:520-6.

14. Shaw $R$, Robinson $M$. The increasing clinical relevance of human papillomavirus type 16 (HPV-16) infection in oropharyngeal cancer. Br J Oral Maxillofac Surg 2011;49:423-9. 
15. Straetmans JMJAA, Olthof N, Mooren JJ, de Jong J, Speel E-JM, Kremer B. Human papillomavirus reduces the prognostic value of nodal involvement in tonsillar squamous cell carcinomas. Laryngoscope 2009;119:1951-7.

16. Rietbergen MM, Brakenhoff RH, Bloemena E, Witte BI, Snijders PJF, Heideman DAM, Boon D, Koljenovic S, Baatenburg de Jong RJ, Leemans CR. Human papillomavirus detection and comorbidity: critical issues in selection of patients with oropharyngeal cancer for treatment De-escalation trials. Ann Oncol 2013;24: 2740-5.

17. Thavaraj S, Stokes A, Guerra E, Bible J, Halligan E, Long A, Okpokam A, Sloan P, Odell $E$, Robinson M. Evaluation of human papillomavirus testing for squamous cell carcinoma of the tonsil in clinical practice. J Clin Pathol 2011;64:308-12.

18. Klussmann JP, Gültekin E, Weissenborn SJ, Wieland U, Dries V, Dienes HP, Eckel $\mathrm{HE}$, Pfister HJ, Fuchs PG. Expression of p16 protein identifies a distinct entity of tonsillar carcinomas associated with human papillomavirus. Am J Pathol 2003;162: 747-53.

19. El-Naggar AK, Westra WH. p16 expression as a surrogate marker for HPV-related oropharyngeal carcinoma: A guide for interpretative relevance and consistency. Head Neck 2011;34:459-61.

20. Rietbergen MM, Leemans CR, Bloemena E, Heideman DAM, Braakhuis BJM, Hesselink AT, Witte BI, Baatenburg-De Jong RJ, Meijer CJLM, Snijders PJF, Brakenhoff $\mathrm{RH}$. Increasing prevalence rates of HPV attributable oropharyngeal squamous cell carcinomas in the Netherlands as assessed by a validated test algorithm. Int J Cancer 2013;132:1565-71.

21. Huang SH, Perez-Ordonez B, Weinreb I, Hope A, Massey C, Waldron JN, Kim J, Bayley AJ, Cummings B, Cho BCJ, Ringash J, Dawson LA, et al. Natural course of distant metastases following radiotherapy or chemoradiotherapy in HPV-related oropharyngeal cancer. Oral Oncol 2013;49:79-85.

22. Ang KK, Sturgis EM. Human papillomavirus as a marker of the natural history and response to therapy of head and neck squamous cell carcinoma. Semin Radiat Oncol 2012;22:128-42.

23. Duensing S, Münger K. Mechanisms of genomic instability in human cancer: insights from studies with human papillomavirus oncoproteins. Int J Cancer 2004; 109:157-62.

24. Patel D, Incassati A, Wang N, McCance DJ. Human papillomavirus type 16 E6 and E7 cause polyploidy in human keratinocytes and up-regulation of G2-M-phase proteins. Cancer Res 2004;64:1299-306.

25. White AE, Livanos EM, TIsty TD. Differential disruption of genomic integrity and cell cycle regulation in normal human fibroblasts by the HPV oncoproteins. Genes \& Development 1994;8:666-77.

26. Brakenhoff RH. Potentially novel options for treatment of HPV-attributable head and neck cancer. Cell Cycle 2013;12:1020-1. 


\section{LIST OF PUBLICATIONS}

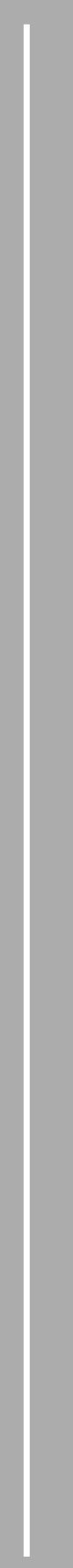




\section{List of publications}

Mooren JJ, Sibel E. Gültekin, Jos M.J.A.A. Straetmans, Annick Haesevoets, Carine J. Peutz-Kootstra, Christian U. Huebbers, Hans P. Dienes, Ulrike Wieland, Frans C.S. Ramaekers, Bernd Kremer, Ernst-Jan M. Speel, Jens P. Klussmann. P16 ${ }^{\text {INK4A }}$ immunostaining is a strong indicator for high-risk HPVassociated oropharyngeal carcinomas and dysplasias, but is unreliable to predict low-risk HPV-infection in head and neck papillomas and laryngeal dysplasias. Int J Cancer. 2014;134:2108-17.

Mooren JJ, Theunissen PH, Zijlker TD. Pathology quiz case: A "Giant" larynx tumour. JAMA Otolaryngol Head Neck Surg. 2013; 139:89.

Mooren JJ, Kremer B, Claessen SMH, Voogd AC, Bot FJ, Klussmann JP, Huebbers CU, Hopman AHN, Ramaekers FCS, Speel EJM. Chromosome stability in tonsillar squamous cell carcinoma is associated with HPV16 integration and indicates a favourable prognosis. Int J Cancer. 2013;132: $1781-9$.

Straetmans JMJAA, Olthof N, Mooren JJ, Speel EJM, Kremer B. Human papillomavirus reduces the prognostic value of nodal status in tonsillar squamous cell carcinoma. Laryngoscope. 2009;119:1951-7.

Mooren JJ, Kremer B. Maligne tumoren van de mondholte. Ned tijdschr Dermatol en venerol 2009;19:484-490.

Hafkamp HC*, Mooren JJ*, Claessen SMH, Klingenberg B, Voogd AC, Bot FJ, Klussmann JP, Hopman AHN, Manni JJ, Kremer B, Ramaekers FCS, Speel EJM. P21 $1^{\text {Cip } 1 / \text { WAF } 1}$ expression is strongly associated with HPV-positive tonsillar carcinoma and a favorable prognosis. Mod Pathol. 2009;22:686-98.

* These authors contributed equally to this study as first authors.

Klussmann JP, Mooren JJ, Lehnen M, Claessen SMH, Stenner M, Siefer O, Weissenborn SJ, Wedemeyer I, Preuss SF, Straatmans J, Manni JJ, Hopman AHN, Speel EJM. Genetic signatures of HPV-related and unrelated oropharyngeal carcinoma and their prognostic implications. Clin Cancer Res. 2009;15:1779-86.

\section{Submitted papers}

Pramana $\mathbf{J}^{*}$, Mooren $\mathbf{J J}^{*}$, van den Brekel M, van Velthuysen L, Kremer B, Begg A, Speel EJ. EGFR expression predicts unfavourable survival in advanced HPV-positive oropharyngeal cancer treated with chemoradiation.

* These authors contributed equally to this study as first authors. 


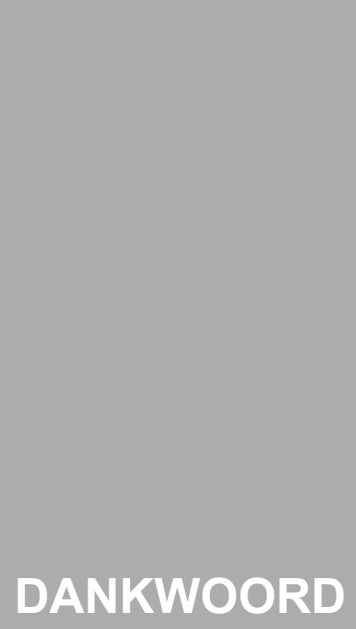




\section{Dankwoord}

Het onderzoek beschreven in dit proefschrift is tot stand gekomen door een samenwerking van de vakgroep KNO-heelkunde, de vakgroep Pathologie en de afdeling Moleculaire celbiologie van het Maastricht Universitair Medisch Centrum. Mijn dank gaat uit naar de vele mensen die een bijdrage hebben geleverd aan de totstandkoming van dit proefschrift. Een aantal personen wil ik in het bijzonder bedanken.

Professor Kremer, beste Bernd, ik wil jou als eerste bedanken voor de kans die je me hebt geboden om mijn opleiding tot KNO-arts in combinatie met dit promotietraject te doorlopen. Jouw grote enthousiasme voor zowel de KNOheelkunde als de wetenschap zijn een enorme inspiratiebron voor mij geweest. Ik heb ontzettend genoten van de vele internationale oncologie congressen, zowel op wetenschappelijk gebied, alsook zeker op sociaal, Bourgondisch en sportief vlak. Je bent een persoon die streeft naar perfectie en die zijn eigen grenzen probeert op te zoeken en verleggen. Dit probeer je ook over te brengen op de mensen waar je mee samenwerkt, wat ervoor zorgt dat personen boven zichzelf uit kunnen stijgen. Hiervoor heb ik veel bewondering.

Professor Speel, beste Ernst-Jan, in het begin van jaar 6 van geneeskunde solliciteerde ik bij jou voor een wetenschapstage bij de Moleculaire Celbiologie. Ik had toen niet durven denken dat dit zou resulteren in het huidige proefschrift. Als iemand meer uren in een dag nodig heeft dan ben jij het wel, maar de soms lange wachttijden voor een afspraak met jou waren dit uiteindelijk zeker waard. Jij hebt elk manuscript in dit proefschrift tot een hoger niveau weten te brengen, waarvoor veel dank. Jij bent iemand die naast zijn werk ontzettend geniet van zijn gezin en hierin zeker grenzen stelt aan waar werk plaats dient te maken voor privé, al is dit niet altijd even makkelijk. Daarom wil ik ook je vrouw en dochters bedanken voor de avonduren die je met mij achter de laptop hebt moeten doorbrengen in plaats van met hen.

Professor Ramaekers, beste Frans, jij bent telkens vol overtuiging bereid geweest om wanneer het einde van een manuscript in zicht kwam, er gedurende een aantal avonden samen kritisch doorheen te lopen, hoe druk je het ook had. Daarnaast was jij vaak degene die kwam met het stellen van deadlines. Daarmee zorgde jij telkens weer voor een extra versnelling, iets dat mijn promotietraject af en toe zeer zeker nodig had. Hiervoor ben ik je erg dankbaar. Ook dankzij jouw kritische vragen en opmerkingen, zijn al mijn manuscripten absoluut van hogere kwaliteit geworden. 
De leden van de beoordelingscommissie onder leiding van professor Geraedts en de corona wil ik hartelijk bedanken voor hun beoordeling van mijn proefschrift en hun aanwezigheid tijdens mijn verdediging.

In particular I would like to thank professor Harald zur Hausen for his participition in the assessment committee and the corona. Prof. zur Hausen discovered the role of human papilloma viruses in the development of cervical cancers, for which he received the Nobel Prize in Physiology or Medicine in 2008. It is a great privelege and honor that you have been willing to critically read my thesis more than 30 years after your identification of HPV16 and -18 in cervical carcinomas.

Alle stafleden, de fellows en de AIOS van $2007 \mathrm{t} / \mathrm{m} 2012$ en andere medewerkers van de afdeling KNO in het MUMC wil ik ontzettend bedanken voor de samenwerking, interesse en gezelligheid in de afgelopen jaren. Ik denk met zeer veel plezier terug aan mijn 5 jaar als AIOS bij de KNO-heelkunde in Maastricht.

Glorious Bastards, Guido, Jan Wouter, Jérôme, Kenneth, Raymond en Rick, bedankt voor alle lief en leed die wij nu bijna 3 jaar met elkaar delen. Inmiddels zijn we verspreid over het land, maar toch weten we soms beter van elkaar waar we mee bezig zijn dan de mensen die we dagelijks zien.

Nadine, veel dank voor al je geduld dat je telkens weer wist op te brengen als deze KNO-arts weer eens iets niet begreep van het onderzoek. Zowel in Vancouver maar ook daarbuiten was jij altijd bereid om mij de zaken even op een eenvoudige en heldere manier uit te leggen. Dit is een talent dat jij bezit, waarvan ik van harte hoop dat je hier in je verdere carrière iets mee kunt gaan doen.

Sandra en Annick, dank voor jullie uitgebreide hulp en adviezen bij het laboratorium werk. Sandra, jij hebt mij geleerd hoe ik de immunohistochemische kleuringen en de FISH kleuringen uit moest voeren en interpreteren, beide technieken onmisbaar voor mijn artikels.

Professor Klussmann and Christian Hüebbers, thank you for the highly valuable collaboration between our institutes and the papers we have written together.

Jimmy Pramana en Michiel van den Brekel, bedankt voor het laatste artikel dat we samen hebben geschreven. Dit was de laatste aanvulling, noodzakelijk voor een mijns inziens compleet proefschrift. 
Tiny Wouters, je hebt me ontzettend veel werk uit handen genomen, waarvoor ik je erg dankbaar ben.

Professor Manni, ook $u$ wil ik hartelijk bedanken. $U$ bent altijd ontzettend geïnteresseerd gebleven in het onderzoek, de ontwikkelingen binnen de KNOheelkunde, maar ook zeker in de personen erachter. Ik heb hier veel bewondering voor.

Intussen maak ik deel uit van de maatschap KNO in het Lievensberg ziekenhuis te Bergen op Zoom. Marc, Gijs en Bart, veel dank voor jullie vertrouwen in mij en de kans om mijn kennis en kunde toe te passen en verder te ontwikkelen binnen jullie maatschap. Ik zie uit naar een langdurige en collegiale samenwerking.

Lieve vrienden en familie, dank voor jullie steun, adviezen en vooral ook voor de onmisbare aanvulling die jullie aan mijn leven geven.

Aquaticus, in het bijzonder Arjan, Michiel en Peter, ontzettend bedankt voor de altijd weer briljante weekendjes weg met dito diners, de vele uren filosoferen over de echte 'belangrijke' zaken in onze levens en de regelmatig schorre stem van het meezingen bij Mariah of Billy. We hebben totaal verschillende karakters wat ons team juist zo karakteriseert. Ik hoop nog lang met jullie van de geneugten des levens te kunnen genieten, waar eenieder van ons zich ook op deze aardbol bevindt. Ik kijk uit naar Tanzania.

Michiel en Peter, jullie wil ik bedanken voor het feit dat jullie mijn paranimfen willen zijn. Dit betekent veel voor me.

Yvette, je bent al sinds het allereerste begin van geneeskunde een ontzettend goede en lieve vriendin. Ik waardeer onze vriendschap enorm en zal mijn uiterste best doen om een plekje voor je te regelen bij de kindergeneeskunde in het Lievensberg ziekenhuis.

Stephanie en Reint, Maarten en Jesse, Michiel en Monique, Celine en Herm, Joris en Roelfien, heel veel dank voor de talloze gezellige momenten, maar bovenal ook voor al jullie steun en hulp als die even nodig was, zowel klein als groot.

Ronde Tafel 57, dank voor het gestelde vertrouwen in mij als persoon binnen deze bijzondere en inspirerende groep. Dankzij jullie krijg ik de kans om nieuwe vriendschappen op te bouwen in Bergen op Zoom en mijzelf verder te ontwikkelen door de grote diversiteit binnen de Tafel. Ik voel me vereerd hiervan deel te mogen uitmaken. 
Lieve pap en mam, jullie wil ik speciaal bedanken voor alles dat jullie altijd voor me hebben gedaan, maar vooral ook nog steeds doen. Ook nu nog is één telefoontje genoeg en weet ik zeker dat ik altijd op jullie hulp kan rekenen. Jullie hebben me altijd de kansen geboden, het vertrouwen gegeven en gestimuleerd om mij te ontwikkelen tot de persoon die ik nu ben. Ik ben trots op jullie als ouders en als opa en oma van onze zoon. Ik geniet er telkens weer van als ik zie hoe jullie genieten van het contact met jullie eerste kleinzoon.

Marc en Jura, jullie dank ik vanuit de grond van mijn hart voor het weer gelukkig en compleet maken van mijn ouders.

Anouk, mijn kleine zusje, dank voor wie je bent. Je bent een zeer sterke en zelfstandige vrouw met een ontzettend groot hart, waar ik zeer veel respect voor heb.

Femke, wie kan ik meer bedanken dan jou? 'Jij verstaat de kunst van bij me horen'. Je vult me aan, je staat voor me klaar en je maakt me gelukkig, tijdens onze vele reizen, maar zeker ook thuis. Voor mijn carrière heb jij je steeds moeten aanpassen aan waar we gingen wonen, wat niet altijd even makkelijk was. Toch deed je dit steeds onvoorwaardelijk en ik hoop dat wij nu samen met onze zoon Oliver van Halsteren/Bergen op Zoom ons nieuwe thuis kunnen gaan maken. En vergeet niet, ik zal me aan mijn belofte houden. We zijn inmiddels 3 jaar getrouwd, wat betekent dat ik nog een ongelofelijk veelvoud hiervan al niet-promoverend samen met jou mag doorbrengen, thuis en ver weg. Ik kijk hiernaar uit!

Oliver, ik weet dat ik een deel van mijn papa-dagen heb moeten besteden aan het afronden van dit proefschrift, maar ik beloof je dat ik je al deze uurtjes in duizendvoud ga teruggeven. Ik ben ontzettend trots dat ik je papa mag zijn en je mag laten zien welk moois deze wereld allemaal te bieden heeft. Als er één ding is dat ik je hoop te kunnen meegeven in dit leven, dan is het wel genieten, zoveel als je kan! Als er één ding is dat jij mij al hebt meegegeven in je nog maar korte leventje, dan is het wel genieten, elk moment dat wij samen zijn. 
CURRICULUM VITAE

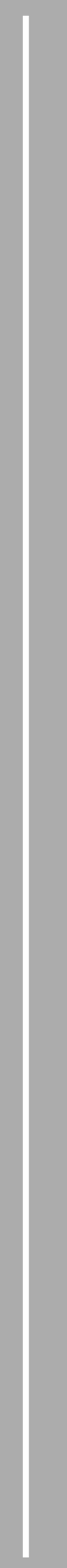




\section{Curriculum Vitae}

Jeroen Mooren werd op 7 september 1981 geboren te Roermond. In 1999 behaalde hij het eindexamen gymnasium aan het Bisschoppelijk college in Roermond. Hierna heeft hij 2 jaar gezondheidswetenschappen gestudeerd aan de Universiteit van Maastricht, aangezien hij uitgeloot was voor geneeskunde. In 2001 kon hij alsnog beginnen met de opleiding geneeskunde, ook aan de Universiteit van Maastricht. Begin 2007 begon hij aan zijn wetenschapsstage bij de afdeling Moleculaire celbiologie onder leiding van prof. dr. Ernst-Jan Speel. Hier werd de basis gelegd voor het huidige proefschrift. Op 29 oktober 2007 behaalde hij zijn artsexamen en op 1 december 2007 startte hij met de opleiding Keel-, Neus- en Oorheelkunde in het Maastricht Universitair Medisch Centrum met als opleider prof. dr. Bernd Kremer en waarnemend opleider prof. dr. Robert Stokroos. De twee perifere opleidingsstages werden gedaan in het Catharina Ziekenhuis te Eindhoven onder supervisie van dr. Frank Adriaansen en dr. Nies Mateijsen en in het Atrium Medisch Centrum te Heerlen onder leiding van dr. Tammo Zijker en drs. Henk Brinkhuis. In zijn laatste jaar van de opleiding, het differentiatiejaar, heeft hij besloten om zich verder te verdiepen in de otologie. Hiervoor is hij gedurende 2 maanden naar het Royal Victorian Eye \& Ear Hospital in Melbourne, Australië onder leiding van prof. dr. Stephen O'Leary en vervolgens naar het Auckland City Hospital, Starship Children's Hospital en Gillies Hospital in Auckland, Nieuw-Zeeland onder leiding van dr. Michel Neeff geweest. In december 2012 behaalde hij zijn KNO-artsexamen, waarna hij gedurende 1 jaar als waarnemend KNO-arts is gaan werken in verschillende klinieken. Per december 2013 is hij toegetreden tot de KNOmaatschap in het Lievensberg ziekenhuis te Bergen op Zoom en woont sindsdien met zijn echtgenote Femke en hun zoon Oliver in Halsteren.

Jeroen Mooren was born in Roermond, the Netherlands, on September $7^{\text {th, }}$ 1981. In 1999 he graduated classical studies at the Bisschoppelijk College in Roermond. He studied health sciences at the University of Maastricht for two years and in 2001 he could eventually initiate his medical study, also at the University of Maastricht. In 2007 he did his scientific internship at the department of Molecular Cell Biology, under supervision of prof. dr. Ernst-Jan Speel. Here, the foundation for the present thesis was made. On October $29^{\text {th }}$, 2007 he obtained his medical degree and enrolled on December $1^{\text {st }}, 2007$ in his training otorhinolaryngology and head and neck surgery at the Maastricht University Medical Center with prof. dr. Bernd Kremer and prof. dr. Robert Stokroos as his supervisors. Part of the training consisted of working at the Catharina Hospital in Eindhoven, under supervision of dr. Frank Adriaansen and dr. Nies Mateijsen and at the Atrium Medical Center in Heerlen, under supervision of dr. Tammo Zijlker and drs. Henk Brinkhuis. In the final year of 
his training he decided to further explore otology. For this purpose, he spent two months at the Royal Victorian Eye \& Ear Hospital in Melbourne, Australia, with prof. dr. Stephen O'Leary and at the Auckland City Hospital, Starship Children's Hospital and Gillies Hospital in Auckland, New Zealand with dr. Michel Neeff. In December 2012, he received his medical degree as otorhinolaryngologist, after which he worked in several clinics as a locum for 1 year. In December 2013 he joined the otorhinolaryngology partnership at the Lievensberg hospital in Bergen op Zoom and lives in Halsteren together with his wife Femke and their son Oliver. 